Blanca Sol Pascual Portal

TESIS DOCTORAL

Año 2019

\title{
POLÍMEROS SENSORES. MEJORA DE SUS PRESTACIONES MEDIANTE MÉTODOS FÍSICOS Y QUÍMICOS
}

Directores:

Prof. Dr. José Miguel García Pérez

Dr. Saúl Vallejos Calzada

Universidad de Burgos DEPARTAMENTO DE QUÍMICA Área de Química Orgánica

Grupo de Polímeros 



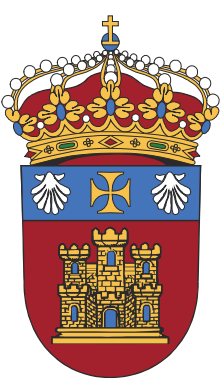

D. José Miguel García Pérez, Catedrático del Área de Química Orgánica, y D. Saúl Vallejos Calzada, investigador postdoctoral del Área de Química Orgánica del Departamento de Química de la Universidad de Burgos,

\section{INFORMAN:}

El trabajo descrito en esta Memoria, titulada Polímeros sensores. Mejora de sus prestaciones mediante métodos físicos y químicos, se ha realizado por Dña. Blanca Sol Pascual Portal en el Departamento de Química de la Universidad de Burgos, bajo nuestra dirección, y autorizan su presentación para que sea calificada como TESIS DOCTORAL.

Burgos, 31 de julio de 2019.

Fdo.: Prof. Dr. José Miguel García

Fdo.: Dr. Saúl Vallejos 

agradezco al camino que me hace aprender y a todas las personas que me han ayudado a recorrerlo. 

CAPÍTULO 1 - Introducción general

1.1. Antecedentes históricos de los polímeros

$\begin{array}{ll}\text { 1.2. Sensores químicos } & 7\end{array}$

$\begin{array}{ll}\text { 1.2.1. Reconocimiento molecular } & 7\end{array}$

1.2.2. Sensores poliméricos 8

1.3. Mejora de las prestaciones de los polímeros sensores $\quad 15$

1.3.1. Estabilización química de las unidades sensoras 17

1.3.2. Material sensor con respuesta dual 17

1.3.3. Generación de estructura microporosa 18

1.4. Objetivos 20

1.5. Estructura de la Memoria 21

CAPÍTULO 2 - Polímeros sensores 23

2.1. Introducción 23

2.2. Detección de fenoles 24

2.2.1. Introducción 24

2.2.2. Matriz polimérica sensora $\quad 27$

2.2.3. Reacción de diazotación. Sales de diazonio 27

2.2.4. Reacción sensora. Acoplamiento diazoico 28

2.2.5. Sensor colorimétrico $\quad 29$

2.3. Detección de atmósferas oxidantes 29

2.3.1. Atmósferas oxidantes: $\mathrm{Cl}_{2}$ y $\mathrm{H}_{2} \mathrm{O}_{2} \quad 29$

2.3.2. Matrices poliméricas $\quad 30$

2.3.3. Respuesta sensora dual 32

2.4. Resultados 34

Polymer films containing chemically anchored diazonium salts with long-term stability as colorimetric sensors $\quad 35$

Easy and inexpensive method for the visual and electronic detection of oxidants in air by using vinylic films with embedded aniline 
CAPÍTULO 3 - Polímeros microporosos sensores $\quad 75$

3.1. Introducción 75

3.2. Generación de estructura microporosa en matrices poliméricas 77

3.3. Comparación entre polímero sensor denso y espumado 83

3.4. Resultados 83

Microcellular polymer films based on cross-linked 1-vinyl-2-pyrrolidone and methyl methacrylate

Microcellular foamed aromatic polyamides (aramids). Structure, thermal and mechanical properties

Porous aromatic polyamides the easy and green way

Sensory polymeric foams as a tool for improving sensory performance of sensory polymers 


\section{RESUMEN/ABSTRACT}

Este trabajo describe el diseño y preparación de filmes poliméricos con capacidad sensora a sustancias de interés, como son compuestos provenientes de la degradación de pesticidas (fenoles), atmósferas oxidantes (cloro y peróxido de hidrógeno) y metales pesados (como el mercurio). Además, se ha abordado la mejora de este tipo de materiales mediante distintos procesos, tanto químicos (mediante la estabilización de sales de diazonio en una matriz polimérica y la generación de una respuesta dual frente a la presencia de oxidantes) como físicos (a través de la generación de estructuras microporosas en filmes vinílicos y poliamidas aromáticas mediante procesos de espumado con $\mathrm{CO}_{2}$ supercrítico y líquidos iónicos).

This work describes the design and synthesis of polymeric films with sensory performance towards substances of interest as compounds from the degradation of pesticides (phenols), oxidizing atmospheres (chlorine and hydrogen peroxide) and heavy metals (as mercury). Additionally, the improvement of these kind of materials has been addressed by different processes both chemical processes (as the stabilization of diazonium salts in a polymeric matrix and the generation of a dual response towards oxidizing agents), as well as physicals processes (as the generation of microporous structures in vinylic films and aromatic polyamides by means of foaming process with supercritical $\mathrm{CO}_{2}$ and ionic liquids). 



\section{CAPÍTULO 1}

\section{Introducción general}

Los polímeros están presentes en prácticamente todos los ámbitos de la vida. La sociedad moderna los ha ido incorporando en los últimos 100 años provocando una auténtica revolución industrial, económica y social. El desarrollo de la Ciencia y Tecnología de Polímeros ha supuesto enormes avances en la fabricación y mejora de materiales que aportan respuestas tecnológicas en campos tan diversos como la automoción, la medicina, la construcción, el envasado, la electrónica o las comunicaciones. En la actualidad, el conocimiento de la estructura y propiedades de los polímeros permite desarrollar materiales a la carta para aplicaciones avanzadas, como por ejemplo la fabricación de tejidos especiales para seguridad y defensa, materiales ultraligeros para la industria aeronáutica y aeroespacial, liberadores de fármacos, o materiales sensores de sustancias de interés mediante reconocimiento molecular. En esta última aplicación es donde se inscribe este trabajo, en el que se profundiza en la síntesis y caracterización de sensores poliméricos y en la mejora de sus propiedades mediante procesos físicos y químicos.

\subsection{Antecedentes históricos de los polímeros}

Los polímeros están presentes desde el origen mismo de la vida. Biomoléculas como el $A D N$, el ARN o las proteínas son ejemplos de biopolímeros esenciales para la vida tal y como la conocemos. Otros polímeros de origen natural también nos han acompañado desde nuestros primeros pasos como especie. 
La madera o el algodón son ejemplos de ello, aunque sobre ellos no se produjera ningún cambio composicional o estructural.

La historia de los polímeros se puede decir que comienza en la primera mitad del siglo XIX. Así, en el año 1839 el estadounidense Charles Goodyear descubrió la vulcanización del caucho natural usando azufre. El caucho es un polímero natural que consiste en su mayor parte en unidades estructurales de cis-isopreno. En el proceso de vulcanización se produce un entrecruzamiento que da lugar a una red tridimensional en la que las cadenas de caucho están unidas por cadenas cortas de átomos de azufre. Poco después, en el año 1846, el químico germano-suizo Christian Friedrich Schönbein sintetizó de manera accidental la nitrocelulosa al limpiar un derrame de ácido sulfúrico y nítrico con un paño de algodón; después de lavar el paño y ponerlo a secar en la estufa, se produjo una explosión sin humo y sin cenizas. A partir de este hecho la nitrocelulosa se destinó a la fabricación de explosivos y propulsores para cohetes, así como en películas fotográficas.

En 1907 se comercializó el primer polímero sintético, la baquelita, patentado por Leo Baekeland. Este material es una resina de fenol-formaldehído que presenta resistencia al agua y a los ácidos, y que se comporta como aislante, tanto térmico como eléctrico, por lo que se utilizó en objetos de uso doméstico, como mangos de sartenes o carcasas de teléfonos, así como en aislamiento eléctrico.

Otro gran avance en la historia de la ciencia de los materiales fue el estudio que realizó Otto Rhöm [1] de los polímeros acrílicos a principios del siglo XX, siendo uno de los mayores exponentes el polimetacrilato de metilo (PMMA), comercializado en el año 1933 con el nombre de Plexiglas [2]. Este polímero presenta rigidez, dureza y alta resistencia al impacto combinado con buena resistencia al desgaste y transparencia. Estas propiedades hacen que el PMMA

[1] O. Rhöm, Ver. Dtsch. Chem. Ges. 1901, 34, 573-574.

[2] O. Rhöm, Chemische Fabrik 1936, 529-530. 
se utilice en automoción, comunicaciones, electrónica, mobiliario y menaje, entre otras aplicaciones.

Todos estos avances se realizaron sin que hubiera una teoría unificada acerca de la estructura de los polímeros. Pese a que el término polímero fue acuñado por primera vez en el año 1833 por Berzelius, hubo que esperar hasta 1920 cuando Hermann Staudinger [3] propuso que la estructura de los polímeros se basaba en la existencia de cadenas largas formadas por la repetición de unidades conectadas mediante enlaces covalentes. Esta idea, que es la base de la teoría estructural de los polímeros, resultó extravagante en la época y no fue hasta 1928 cuando se dio por válida tras las observaciones por rayos $X$ realizadas por Kurt Meyer y Herman Mark. En 1953 el reconocimiento a Staudinger por la importante aportación al mundo de los polímeros llegó en forma de Premio Nobel.

Otros hitos relacionados con la síntesis y producción de polímeros se produjeron durante los años 30 del siglo pasado con la aparición del policloruro de vinilo, el politetrafluoroetileno y el poliestireno. También en esta época se empezaron a sintetizar las primeras poliamidas a partir de diácidos y diaminas. Wallace Carothers fabricó en 1935 la primera fibra sintética que se utilizaría a escala industrial, el Nylon, una poliamida que se utilizó en la fabricación de medias, así como de cuerdas y paracaídas.

Karl Ziegler y Giulio Natta desarrollaron catalizadores para la síntesis estereoespecífica de poliolefinas, lo que se tradujo en un gran aumento del volumen de producción de polietileno de alta densidad y del polipropileno. En 1963 ambos investigadores recibieron el premio Nobel en Química por sus aportaciones a la catálisis y a la ciencia de los polímeros.

Durante la década de 1960 se desarrolló la química supramolecular y con ello el concepto de reconocimiento molecular. Pedersen [4], Lehn [5] y Cram [6] recibieron el Nobel de Química en el año 1987 por su labor en este campo.

[3] H. Staudinger, Naturwissenschaften 1955, 42, 221-230.

[4] C.J. Pedersen, J. Am. Chem. Soc. 1967, 89, 7017-7036. 
En los años 70 del siglo pasado los científicos Alan Jay Hegger, Alan McDiarmid y Hideki Shirakawa descubrieron que el poliacetileno expuesto a vapores de iodo daba como resultado un material conductor [7]. Este hecho propició el desarrollo de la química de los polímeros conductores, siendo en la actualidad sus mayores exponentes la polianilina (PANI), el polidioxitiofeno (PEDOT) y el polipirrol (PPy). En el año 2000 estos investigadores recibieron el Premio Nobel de química por sus estudios acerca de los polímeros conductores, tema que continúa hoy en día en expansión.

Los avances que se han llevado a cabo desde entonces en la ciencia de los polímeros son enormes y abarcan áreas del conocimiento tan diversas como la automoción, la electrónica, las comunicaciones, la medicina, la biología, la ingeniería espacial, la industria alimentaria, la industria farmacéutica, el medioambiente, la seguridad civil y la nanotecnología. En los últimos años las implicaciones medioambientales de los polímeros están cobrando especial relevancia, lo que hace que cada vez se busquen opciones más sostenibles tanto en los procesos de fabricación (evitando el uso de disolventes orgánicos), como en los materiales en sí mismos (modificación de polímeros naturales fácilmente biodegradables). Todo ello acompañado de una cultura del reciclaje cada vez más asentada en la sociedad.

Uno de estos avances lo constituye el empleo de los polímeros como sistemas inteligentes capaces de detectar sustancias en su entorno de manera de específica, es decir, un sistema de detección polimérico, o sensor polimérico. A continuación, se describe el concepto de sensor químico y el fenómeno del reconocimiento molecular, para explicar posteriormente con más detalle los sensores poliméricos, sus características y clasificación.

[5] J.M. Lehn, Science 1985, 227, 849-856.

[6] D.J. Cram, A. Ratajczak, J. Am. Chem.Soc. 1968, 90, 2198-2200.

[7] H. Shirakawa, E.J. Louis, A.G. MacDiarmid, C.K. Chiang, A.J. Heeger J. Chem. Soc., Chem. Commun. 1977, 578-580. 


\subsection{Sensores químicos}

El objetivo principal que se describe en esta memoria consiste en la profundización en el estudio de materiales poliméricos con capacidad sensora, así como su mejora mediante métodos físicos y químicos. Por ello resulta clave entender el proceso de detección basado en el fenómeno conocido como reconocimiento molecular, que se describe a continuación.

\subsubsection{Reconocimiento molecular}

La química supramolecular es la rama del conocimiento que estudia las interacciones intermoleculares que dan lugar al reconocimiento molecular y a la formación de agregados. Fue en el año 1978 cuando el químico francés JeanMarie Lehn acuñó el término de química supramolecular, o química anfitriónhuésped, tras observar los fenómenos de reconocimiento molecular que se daban en la naturaleza.

El reconocimiento molecular se fundamenta en la complementariedad química y geométrica entre dos o más moléculas que permite el establecimiento entre ellas de interacciones espaciales débiles. Estas interacciones pueden ser electrostáticas, hidrofóbicas, en forma de enlaces de hidrógeno y coordinaciones débiles metal-ligando [8]. El término de química anfitriónhuésped hace referencia a la interacción entre dos moléculas en las que una, el anfitrión, es capaz de albergar o reconocer a la otra, el huésped.

Existen muchos casos de reconocimiento molecular en la naturaleza. Algunos ejemplos son la interacción enzima/sustrato [9], fármaco/diana biológica [10], antígeno/anticuerpo [11], y la síntesis del ARNm a partir del ADN [12].

Las moléculas sensoras basan su proceso de detección en el reconocimiento molecular, en el que la sustancia de interés actúa como huésped y, el propio

[8] N.M. Bergmann, N. Peppas, Prog. Polym. Sci. 2008, 33, 271-288.

[9] A. Tulinsky, Sem. Thromb. Hemostasis. 1996, 22, 117-124.

[10] M. Britschgi, S. von Greyerz, C. Burkhart, W.J. Pichler, Curr. Drug. Targets. 2003, 4, 1-11.

[11] E.J. Sundberg, R.A. Mariuzza, Adv. Protein. Chem. 2002, 61, 119-160.

[12] S.A. Hofstadler, R.H. Griffery, Chem. Rev. 2001, 101, 377-390. 
sensor como anfitrión. Seguidamente se tiene que producir un proceso de transducción en el que el reconocimiento molecular produzca algún tipo de señal cuantificable. En general, un sensor debe constar de una parte receptora, encargada de interaccionar selectivamente con el analito, y una indicadora que produzca una señal cuantificable. La Figura 1.1 muestra gráficamente el proceso de detección por parte de un sensor químico.

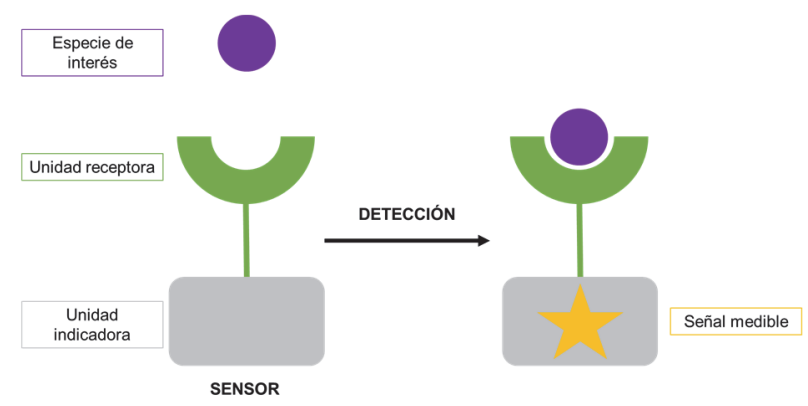

Figura 1.1. Proceso de detección de una especie de interés por un material sensor que da lugar a una señal cuantificable.

\subsubsection{Sensores poliméricos}

Los sensores químicos más tradicionales suelen ser moléculas orgánicas u organometálicas con masas moleculares pequeñas, que en general presentan algunos inconvenientes en su aplicación, como son una baja solubilidad en agua, poca estabilidad frente a la luz, baja resistencia térmica, o tendencia a la migración cuando están dispersadas sobre soportes físicos [13].

El diseño de sensores poliméricos permite sortear muchos de estos inconvenientes, por la versatilidad que presentan:

- En cuanto a su composición, ya que se pueden usar distintos comonómeros que aporten diferentes grados de hidrofilia/hidrofobia, elasticidad/rigidez, transparencia/opacidad, biocompatibilidad, permitiendo obtener propiedades a la carta [14]. Este punto es clave en

[13] A.M. Sanjuán, J.A. Reglero, F.C. García, J.M. García, React. Funct. Polym. 2018, 133, 103 125.

[14] S. Vallejos, P. Estévez, S. Ibeas, A. Muñoz, F.C. García, F. Serna, J.M. García, Sens. Actuators B-Chem. 2011, 157, 686-690. 
el marco de este trabajo, ya que en las aplicaciones que se verán más adelante se ha tenido que llegar a una situación de compromiso que permita que el material sensor presente una capacidad de absorción de agua aceptable, sin pérdida importante de sus propiedades mecánicas.

- En cuanto a su forma, al ser posible diseñar distintas estructuras o morfologías, como por ejemplo sensores poliméricos en forma de recubrimientos, hidrogeles, filmes, fibras. Asimismo, como muestran las investigaciones más recientes, se pueden obtener materiales nanoestructurados como nanopartículas, cepillos poliméricos, materiales nanoporosos o nanofibras [15]. Los avances que se presentan en este trabajo se basan todos ellos en matrices poliméricas en forma de membranas densas o filmes.

Dentro del campo de los sensores poliméricos podemos diferenciar varios grupos o familias en función de su composición o su modo de preparación:

- Polímeros impresos molecularmente (MIPs). Estos materiales se preparan polimerizando los monómeros en presencia de la especie objetivo, que posteriormente es eliminada dejando huecos con la forma específica para que se dé el reconocimiento molecular. Estos "anticuerpos plásticos" ofrecen muchas posibilidades en el campo de los materiales sensores, en el caso, por ejemplo, de la detección de drogas [16] o incluso en el diagnóstico de cáncer de pulmón [17].

- Nanocomposites poliméricos y polímeros híbridos. Los nanocomposites poliméricos se preparan mediante técnicas de polimerización simples con partículas orgánicas, como nanotubos de carbono, grafeno o nanopartículas metálicas [18]. Por su parte, en los polímeros híbridos

[15] B. Sanz, C. von Bilderling, J.S. Tuninetti, L. Pietrasanta, C. Mijangos, G.S. Longo, O. Azzaroni, J.M. Giussi, Soft Matter. 2017, 13, 2453-2464.

[16] A. Yaman, S. Kurbanoglu, K.J. Jetzschmann, S.A. Ozkan, U. Wollenberger, F.W. Scheller Curr. Med. Chem. 2018, 25, 4007-4019.

[17] J. Liu, Y. Wang, X. Liu, Q. Yuan, Y. Zhang, Y. Li Talanta 2019, 199, 573-580.

[18] J.K.Y. Lee, N. Chen, S. Peng, L. Li, L. Tian, N. Thakor, S. Ramakrishna Prog. Polym. Sci. 2018, 86, 40-84. 
las unidades orgánicas e inorgánicas están unidas covalentemente. Ambas aproximaciones tienen como resultado un abanico enorme de posibilidades a la hora de combinar las distintas propiedades de cada material para obtener un material mejorado [19].

- Polímeros acrílicos, vinílicos y poliamidas aromáticas. En cuanto a los polímeros acrílicos, nos referimos a polímeros derivados del ácido acrílico o metacrílico y de la acrilamida. En lo referente a los polímeros vinílicos los monómeros más usados son la $N$-vinilpirrolidona así como los derivados de estireno. En el caso de las poliamidas aromáticas, se emplean derivados de la $m$-fenilendiamina. Estas familias de polímeros ofrecen, por un lado, la posibilidad de anclar gran variedad de unidades sensoras a su estructura y, por otro, modular la capacidad de absorción de agua y sus propiedades mecánicas. Así, por ejemplo, dentro del grupo de investigación $\mathrm{S}$. Vallejos y col. describen entre otras aplicaciones, el uso de filmes acrílicos para la detección de cloruros en sudor y su aplicación en el diagnóstico de la fibrosis quística [20]. Los polímeros acrílicos y vinílicos serán la base de los materiales sensores que se describirán más adelante en esta memoria. Las poliamidas aromáticas, por su parte, se tratarán desde el punto de vista de la mejora de propiedades por generación de estructuras microporosas.

- Polímeros con unidades quirales. La presencia de ligandos quirales permite el reconocimiento estereoespecífico de distintas especies de interés [21]. Esto resulta de gran importancia en aplicaciones médicas y farmacéuticas en la elaboración de medicamentos, ya que en muchos casos moléculas con una determinada configuración son activas y beneficiosas, mientras que sus enantiómeros son inactivos o incluso nocivos.

[19] S. Chakravarty, A. Datta, N.S. Sarma J. Mater. Chem. C 2017, 5, 2871-2882.

[20] S. Vallejos, E. Hernando, M. Trigo, F.C. García, M. García-Valverde, D. Iturbe, M.J. Cabero, R. Quesada, J.M. García J. Mater. Chem. B 2018, 6, 3735-3741.

[21] X. Zhang, J. Yin, J. Yoon, Chem. Rev. 2014, 114, 4918-4959. 
- Polímeros conductores. Presentan alternancia de enlaces sencillos y enlaces dobles, lo que produce una conjugación extensa (solapamiento de los orbitales $\pi$ ), que en estado dopado permiten la conducción eléctrica [22]. Estos materiales resultan muy interesantes al combinar la manejabilidad, ligereza y fácil procesado de los polímeros con la conductividad eléctrica, que en algunos casos se aproxima a la de los metales. La PANI, el PEDOT o el Ppy son algunos de los compuestos más estudiados en este campo [23]. Estos tres polímeros conductores se sintetizan químicamente de forma muy sencilla mediante la adición un agente oxidante a una disolución ácida del monómero correspondiente. Como se verá más adelante, en este trabajo se ha utilizado el mecanismo de polimerización que da lugar a la PANI para la detección de especies oxidantes.

Podemos también clasificar los polímeros sensores en función de la respuesta que producen al interaccionar con la sustancia de interés, así podemos encontrar:

- Sensores resistivos. Cuya respuesta se basa en cambios en la resistividad eléctrica del material sensor al entrar en contacto con la sustancia objetivo. Dentro de este grupo de sensores destacan los polímeros conductores. En este sentido se puede partir de un polímero sensor que presenta conductividad eléctrica y que por interacción con la molécula de interés pasa a un estado aislante. O bien, partir de un material sensor aislante que adquiere conductividad eléctrica al entrar en contacto con la sustancia de interés. Este tipo de respuesta es fácilmente medible y permite alcanzar límites de detección muy bajos. Como se ha mencionado en el punto anterior, el uso de la polimerización de anilina para dar PANI en presencia de una atmósfera

[22] G. Kaur, R. Adhikari, P. Cass, M. Bown, P. Gunatillake, RSC Adv. 2015, 5, 37553-37567.

[23] K. Tapan, D. Prusty, S. Prusty, Polym. Plast. Technol. Eng. 2012, 51, 1487-1500. 
oxidante constituye un ejemplo de este tipo de sensores, al variar la resistividad total del sistema.

- Sensores ópticos. La respuesta en estos sensores poliméricos se basa bien en un cambio de color del material, o bien en un cambio de la luminiscencia, ya sea fluorescencia o fosforescencia. En el caso de la respuesta luminiscente, la interacción del polímero sensor con la sustancia de interés puede dar lugar a dos fenómenos. En el primero, el analito de interés genera fluorescencia o fosforescencia al interaccionar con el material sensor. En el segundo, la interacción polímero sensor-analito produce una disminución de luminiscencia.

En lo que respecta a las variaciones cromáticas, es de gran interés la detección a simple vista. Una alternativa a la espectroscopia UV-Vis consiste en la utilización de un dispositivo móvil (p. ej., teléfono móvil) con el que se puedan tomar fotografías de las variaciones cromáticas del sensor al detectar la sustancia de interés.

Teniendo en cuenta el modelo de color RGB (modelo aditivo de los colores primarios rojo $(R)$, verde $(G)$ y azul $(B)$ ), se pueden obtener valores asociados a cada color, lo que permite definir de forma cuantitativa las fotografías. Estos valores, separados en componentes o combinados se pueden tratar matemáticamente para obtener una recta de calibrado en la que se relacione la concentración de la especie objetivo con los cambios de color del material sensor.

Esto permite que el proceso de detección y cuantificación sea sencillo, rápido y barato, pues evita el empleo de equipos y de personal especializado. La Figura 1.2 resume el proceso de detección y cuantificación que tiene su base en los parámetros RGB. 


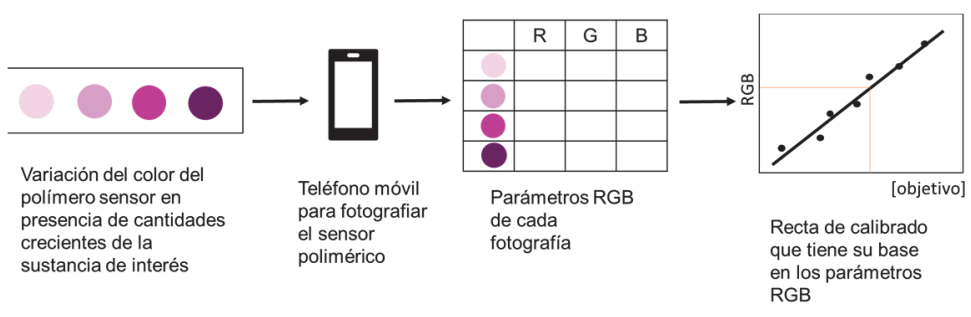

Figura 1.2. Proceso de detección y cuantificación basado en el modelo de color RGB empleando un sensor colorimétrico.

Esta técnica de detección y cuantificación se ha utilizado en repetidas ocasiones en el grupo de investigación, así como en los trabajos que se presentan en esta memoria, obteniéndose límites de detección y cuantificación bajos, por lo que constituye una herramienta muy útil en el ámbito de los materiales sensores.

En relación con los tipos de sustancias que se pueden detectar con los polímeros sensores, algunas de las más relevantes son:

- Cationes y aniones metálicos. En este campo es de especial interés el desarrollo de polímeros sensores capaces de detectar especies contaminantes en alimentos o agua, dada la importancia que tiene la seguridad en la industria alimentaria. Existen numerosas publicaciones relacionadas con la detección de cationes y aniones [24, 25]. En muchos casos la respuesta sensora se basa en variación del color o de fluorescencia, aunque también se describen respuestas electroquímicas y resistivas [26]. Dentro del propio grupo de investigación se encuentran ejemplos de detección de estas especies en los artículos relacionados con la detección de mercurio en agua [27], la detección de hierro en sangre, vino y agua [28], o la detección de cianuro [29], por poner algunos ejemplos.

[24] V. Somerset, J. Leaner, R. Manson, E. Iwuoha, M. Aoife, Int. J. Environ. Anal. Chem. 2010, 90, 671-685.

[25] A. Chen, W. Wu, M.E. Fegley, S.S. Pinnock, J.L. Duffy-Matzner, W.E. Bernier, W.E. Jones Jr, Polymers 2017, 9, 118-130.

[26] A.M. Sanjuán, J.A. Reglero, F.C. García, J.M. García, React Funct Polym. 2018, 133, 103-125.

[27] S. Vallejos, J.A. Reglero, F.C. García. J.M. García, J. Mater. Chem. A 2017, 5, 13710-13716. 
- Gases y compuestos orgánicos volátiles (VOCs). La detección de compuestos volátiles en ámbitos laborales o domésticos resulta de gran importancia. En cuanto a la seguridad y prevención laboral, cada vez se está haciendo más hincapié en el cumplimiento de las directrices de calidad e higiene en el trabajo, que, en determinados puestos como la industria, los laboratorios y la construcción se pueden ver comprometidas por la presencia de sustancias nocivas en el ambiente. El uso de polímeros sensores puede permitir una rápida detección de estas sustancias por personal no especializado. Otra aplicación en la detección de los compuestos volátiles es el envasado inteligente que avisa del estado de un alimento indicando si es apto o no para el consumo [30]. También existen ejemplos de detección de vapores de alta acidez, como el que se basa en fibras textiles recubiertas de poliamidas aromáticas [31].

- Explosivos y agentes de guerra química. Muchos de estos compuestos pueden ser sustancias gaseosas, por lo que podrían incluirse en el apartado anterior, pero debido a su relevancia tienen un campo propio de investigación. El interés por desarrollar más y mejores sensores para estas sustancias se explica por la amenaza terrorista, que hace necesarios controles mucho más exhaustivos. Se requieren detectores rápidos y fáciles de utilizar por personal no cualificado en lugares como aeropuertos o estaciones de tren, por ejemplo. Existen ejemplos de sensores poliméricos capaces de detectar explosivos como el TNT, el

[28] S. Vallejos, A. Muñoz, S. Ibeas, F. Serna, F.C. García, J.M. García, J. Mater. Chem. A 2013, 1, 15435-15441.

[29] S. Vallejos, P. Estévez, F.C. García, F. Serna, J.L. de la Peña, J.M. García, Chem. Commun. 2010, 46, 7951-7953.

[30] J.L. Pablos, S. Vallejos, A. Muñoz, M.J. Rojo, F. Serna, F.C. García, J.M. García, Chem.: Eur. J. 2015, 21, 8733-8736.

[31] M. Trigo-López, J.L. Pablos, A. Mendía, A. Muñoz, F. Serna, F.C. García, J.M. García, Polym. Chem. 2015, 6, 3110-3120. 
dinitrobenceno o la hidrazina [32-34], así como agentes de la guerra química [35].

- Biomoléculas. El estudio y detección de estas moléculas de origen natural resulta clave en campos de la ciencia como la medicina, la biomedicina o la ingeniería biomédica. Algunos ejemplos de estas moléculas son los aminoácidos y, por tanto, también las proteínas y enzimas, o los ácidos nucleicos, ADN y ARN. Dentro de este grupo podemos encontrar polímeros sensores capaces de detectar drogas, hormonas o neurotransmisores, como es el caso de la tetraciclina [36], la dopamina [37], o la epinefrina [38].

\subsection{Mejora de las prestaciones de los polímeros sensores}

Una vez presentado el concepto de polímeros sensores, los tipos que existen y sus aplicaciones, se describen a continuación los tres parámetros que definen la calidad de un sensor: el tiempo de respuesta, la sensibilidad y la selectividad. El tiempo de respuesta de un material sensor se define como el tiempo que tarda ese sensor en producir una señal tras interaccionar con la especie de interés. Una disminución de este tiempo se traduce en un proceso de detección más rápido, lo que en muchas aplicaciones puede ser clave, como las relacionadas con la seguridad y prevención en el trabajo (laboratorios, industrias o construcción) o el control en espacios públicos (detección de drogas o explosivos).

La sensibilidad de un material sensor hace referencia a la cantidad mínima de la sustancia de interés que al entrar en contacto con el material sensor produce una señal cuantificable. Por tanto, las mejoras de los materiales sensores a

[32] J.L. Pablos, M. Trigo-López, F. Serna, F.C. García, J.M. García, RSC Adv. 2014, 4, 2556225568

[33] F. Chu, G. Tsiminis, N.A. Spooner, T.M. Monro, Sens. Actuators B Chem. 2014, 199, 22-26.

[34] S.W. Thomas, T.M. Swager, Adv. Mater. 2006, 18, 1047-1050.

[35] D. Pangeni, E.E. Nesterov, Macromolecules 2013, 46, 7266-7273.

[36] L.Q. Wang, F.Y. Lin, L.P. Yu, Analyst 2012, 137, 3502-3509.

[37] B. Rezaei, M.K. Boroujeni, A.A. Ensafi, Biosens. Bioelectron. 2015, 66, 490-496.

[38] B.B. Prasad, A. Srivastava, A. Prasad, M.P. Tiwari, Colloids Surf. B 2014, 113, 69-76. 
este respecto van encaminadas a ajustarse lo máximo posible a los requerimientos de su aplicación, lo que en muchos casos se traduce en disminuir al máximo los límites de detección (cantidad mínima de sustancia de interés detectable por el material sensor) y cuantificación (cantidad mínima de sustancia de interés que se puede cuantificar al emplear el material sensor).

Por último, la selectividad se refiere a la capacidad del sensor de distinguir entre la especie de interés y otras especies que pueden actuar como interferentes. En este sentido, es fundamental disminuir el efecto de los interferentes diseñando sensores que interaccionen específicamente con la sustancia de interés y que no den respuesta frente a la presencia de sustancias similares.

Teniendo presentes estos tres conceptos, el enfoque de esta memoria se dirige a mejorar las prestaciones de materiales poliméricos sensores mediante procesos químicos y físicos. Estas mejoras se han llevado a cabo mediante las siguientes aproximaciones:

- Estabilización química de unidades sensoras al incorporarlas a matrices poliméricas.

- Fabricación de materiales sensores con respuesta dual. Esta mejora consiste en que el polímero sensor genere dos respuestas simultáneas al interaccionar con la especie de interés.

- Generación de estructuras microporosas con el objetivo de disminuir el tiempo de respuesta asociada al aumento de la superficie específica del material sensor.

A continuación, se describen brevemente estos procesos que han permitido la mejora de los sensores poliméricos estudiados. 


\subsubsection{Estabilización química de las unidades sensoras}

Recientemente, en el grupo de investigación se ha estado trabajando en síntesis en estado sólido sobre los filmes para la incorporación de subgrupos sensores. El resultado fue sorprendente por diversos motivos. Así, las síntesis en cadena que se planificaron se llevaron a cabo en condiciones poco agresivas, en base acuosa y de forma rápida y cuantitativa. Además, se pudo comprobar que especies poco estables en condiciones habituales en química, especialmente en disolución, eran esencialmente estables en el estado sólido particular que supone un filme hidrofílico, tanto seco como hidratado [27].

Teniendo en cuenta estos antecedentes, en esta tesis se planteó la obtención de filmes poliméricos sensores estables que contenían sales de diazonio. Estos compuestos se consideran muy inestables en condiciones ambientalmente habituales. Si embargo, la utilización de una matriz polimérica como soporte de estas sustancias ha posibilitado su utilización como sensor de fenoles en medios acuosos, obteniéndose materiales sensores estables a lo largo del tiempo que dieron lugar a respuestas fácilmente cuantificables [39].

\subsubsection{Material sensor con respuesta dual}

Como se ha mencionado, una respuesta dual consiste en la generación de dos señales de salida frente al mismo estímulo de entrada, como queda reflejado en la Figura 1.3.

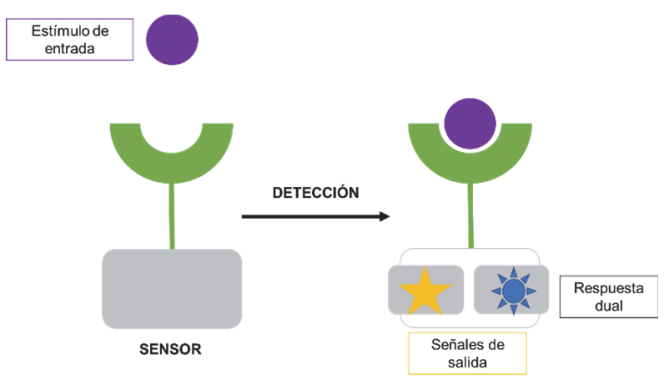

Figura 1.3. Sensor con respuesta dual, que frente a un mismo estímulo produce dos señales de respuesta de forma simultánea.

[39] B.S. Pascual, S. Vallejos, C. Ramos, M.T. Sanz, J.A. Reglero Ruiz, F.C. García, J.M. García, Sensors 2018, 18, 4378-4386. 
El diseño de un sensor que presente una respuesta dual supone una gran ventaja frente a un sensor de respuesta simple. Por un lado, se genera el doble de información frente a un mismo estímulo, lo que facilita el proceso de detección. Por otro, el proceso de detección es más fiable al contar con dos criterios de respuesta. La sensibilidad y selectividad se ven, por tanto, mejoradas.

En este sentido, en este trabajo se han desarrollado materiales sensores que cambian de color ante la sustancia objetivo, en nuestro caso gases oxidantes, $y$, paralelamente, modifican su comportamiento eléctrico, pasando de aislantes a conductores [40].

\subsubsection{Generación de estructura microporosa}

El tercer enfoque que se ha tomado para la mejora de los polímeros sensores consiste en la generación de una estructura microcelular o microporosa. La superficie específica de un material sensor constituye un parámetro clave en el proceso de detección. Por ello, resulta razonable pensar que la creación de huecos o poros en el interior y/o en la superficie del material sensor puede favorecer la interacción entre las unidades receptoras de este con las moléculas objetivo, así como los fenómenos de difusión al interior del material. En los trabajos descritos en esta memoria la detección se ha llevado a cabo en fase acuosa y en fase gas. En ambos casos la interacción entre la sustancia de interés y las unidades receptoras del sensor se produce por difusión previa de las moléculas objetivo en el material sensor, siguiendo la Ley de Fick. El paso de polímeros sensores densos a microporosos se ha realizado a través de dos procedimientos distintos que son: el espumado mediante $\mathrm{CO}_{2}$ supercrítico $\left(\mathrm{ScCO}_{2}\right)$ y el empleo líquidos iónicos (ILs).

Existen dos métodos generales de espumado físico con $\mathrm{ScCO}_{2}$ : espumado en un paso [41] y espumado en dos pasos [42]. En el espumado en dos pasos el

[40] B.S. Pascual, S. Vallejos, J.A. Reglero Ruiz, J.C. Bertolín, C. Represa, F.C. García, J.M. García, J. Hazard. Mater. 2018, 364, 238-243.

[41] J.A. Reglero, M. Pedros, J.-M. Tallon, M. Dumon, J. of Supercrit Fluids 2011, 58, 168-176. 
material se satura con $\mathrm{ScCO}_{2}$ a altas presión es y a temperaturas bajas, y posteriormente se reduce la presión atmosférica, lo que da lugar a la nucleación. Seguidamente el polímero se calienta por encima de la Tg, lo que permite un crecimiento controlado de los poros.

En esta memoria el método que se ha seguido es el espumado en un paso, que se describe a continuación. El proceso de espumado de un polímero amorfo con $\mathrm{ScCO}_{2}$ en un paso se puede explicar en tres etapas:

- En una primera etapa se tiene dentro del reactor la muestra polimérica y $\mathrm{CO}_{2}$ a una determinada presión, formando un sistema de dos fases.

- En una segunda etapa se aumenta la presión de $\mathrm{CO}_{2}$ por encima de su punto crítico para saturar la muestra, dando lugar a un sistema de una sola fase en la que el polímero se encuentra sobresaturado de $\mathrm{ScCO}_{2}$.

- En la tercera etapa se produce la despresurización rápida del sistema, lo que provoca que la temperatura disminuya drásticamente $\mathrm{y}$, paralelamente, que el $\mathrm{CO}_{2}$ pase de estado supercrítico a estado gas. En este momento se crea la estructura celular.

En esta memoria se describe el empleo del espumado mediante $\mathrm{ScCO}_{2}$ en filmes vinílicos obteniéndose buenos resultados y una alta reproducibilidad.

En relación con la generación de estructura microporosa mediante líquidos iónicos (ILs), indicar que los ILs son especies compuestas por un catión de naturaleza orgánica y un anión que puede ser tanto orgánico como inorgánico. Estos están considerados, además, disolventes verdes, fácilmente reciclables y que no presentan problemas relacionados con la presión de vapor [43]

En el contexto de esta memoria, el interés en los ILs se basó en un principio en su afinidad por el $\mathrm{CO}_{2}$ [44], lo que a priori puede facilitar el proceso de absorción de $\mathrm{ScCO}_{2}$ en poliamidas aromáticas (PA) permitiendo el proceso de

[42] J.A. Reglero, J.-M. Tallon, M. Pedros, M. Dumon, J. of Supercrit Fluids 2011, 57, 87-94.

[43] H. Zhang, J. Wu, J. Zhang, J. He, Macromolecules 2005, 38, 8272-8277.

[44] A. Wilke, J. Yuan, M. Antonietti, J. Weber, ACS Macro Lett. 2012, 1, 1028-1031. 
espumado, que se ha explicado previamente. Es importante remarcar que las poliamidas aromáticas presentan una elevada cristalinidad que dificulta mucho la absorción de $\mathrm{CO}_{2} \mathrm{y}$, por tanto, el espumado físico basado en $\mathrm{ScCO}_{2}$.

Como se verá más adelante, los ILs, además de promover el espumado con $\mathrm{ScCO}_{2}$ en poliamidas aromáticas, también son capaces de generar por sí mismos filmes con estructura microporosa mediante un proceso térmico de separación de fases. El proceso térmico de separación de fases consiste en el paso de un sistema homogéneo de una fase, a una determinada temperatura, a un sistema de dos fases a una temperatura inferior a la anterior. Este proceso es reversible térmicamente y se explica gráficamente en la Figura 1.4.

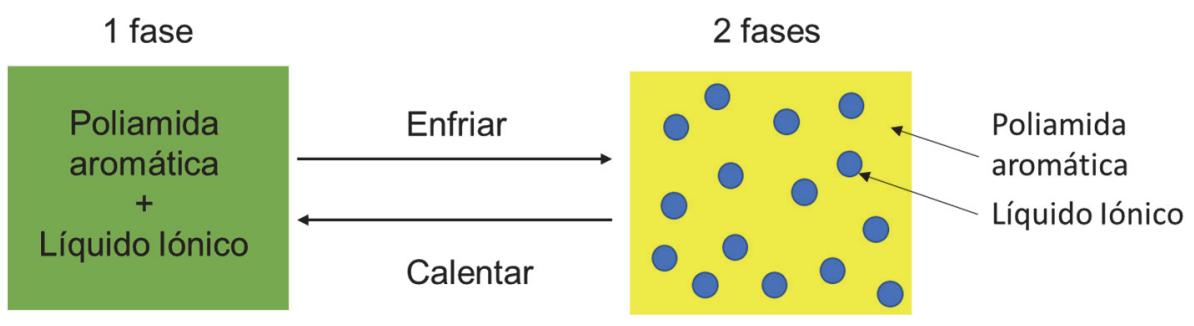

Figura 1.4. Proceso térmico de inversión de fase en el sistema PA/IL.

\subsection{Objetivos}

El objetivo principal de la tesis consiste en profundizar en el estudio de polímeros sensores hacia especies de interés, mejorando sus prestaciones mediante métodos físicos y químicos. Estas especies de interés son relevantes en ámbitos como protección civil, seguridad alimentaria, biomedicina o medioambiente.

Los objetivos parciales que se plantean para conseguir el objetivo principal son:

- Estudiar los posibles métodos físicos y químicos existentes para mejorar en uno o varios aspectos los materiales poliméricos sensores.

- Optimizar la aplicación de estos métodos en función de la mejora que se quiere obtener, atendiendo a parámetros como aumento de la superficie específica del material, mejora de la estabilidad química de 
la unidad receptora sensora, obtención de respuesta sensora dual frente a un mismo estímulo y mejora de propiedades de manejabilidad y estabilidad ambiental de los polímeros sensores.

- Evaluar las mejoras obtenidas en los polímeros sensores en función del tiempo de respuesta, sensibilidad y selectividad como camino hacia nuevas propuestas de sensores poliméricos más eficientes.

\subsection{Estructura de la Memoria}

El trabajo realizado para la consecución de los objetivos planteados se presenta en esta memoria dividida en 3 capítulos, que incluye en primer lugar esta introducción, en la que se explica de manera general el contexto y objetivos del trabajo llevado a cabo.

Los capítulos siguientes son una descripción de la metodología y los trabajos realizados para la consecución de dichos objetivos. En el capítulo 2 se describe, en primer lugar, la síntesis y caracterización de polímeros sensores para la detección de fenoles procedentes, en su mayor parte, de la degradación de pesticidas y biocidas. Esta detección se lleva a cabo mediante la reacción con una subunidad sensora (sal de diazonio) anclada a la matriz polimérica. En segundo lugar, se analizan los resultados relativos a la detección de atmósferas oxidantes, mediante la polimerización de PANI. En ambos casos se presentan mejoras en los materiales sensores, como son la generación de una respuesta dual, en el caso de la detección de atmósferas oxidantes, y la estabilización de las sales de diazonio en una matriz polimérica, en relación con la detección de fenoles.

El capítulo 3 se centra en la descripción de la generación de estructuras microporosas en distintas matrices poliméricas, así como en la aplicación de esta estructura a un sensor polimérico previamente diseñado por el grupo para la detección de mercurio en agua. Las matrices poliméricas utilizadas son filmes de base vinílica y poliamidas aromáticas y los métodos de generación de estructuras microporosas empleados se dividen en espumado con $\mathrm{ScCO}_{2}$, 
espumado con $\mathrm{ScCO}_{2} / \mathrm{LLs}$ y empleo de ILs y su posterior eliminación. También se describe la aplicación de esta mejora en un filme polimérico sensible al $\mathrm{Hg}(\mathrm{II})$.

Por último, se recogen las conclusiones extraídas en el desarrollo del trabajo, se analiza el cumplimiento de los objetivos fijados y se plantean perspectivas de futuro. 


\section{CAPÍTULO 2}

\section{Polimeros sensores}

Los polímeros sensores se caracterizan por su capacidad de respuesta a estímulos de manera reversible (quimiosensores) o irreversible (dosímetros químicos). En general, se habla de polímeros sensores englobando los dos conceptos. Este capítulo describe la síntesis de dos materiales sensores basados en matrices poliméricas compuestas fundamentalmente por monómeros vinílicos y acrílicos. En el primer caso que se presenta, además de estos comonómeros, está también presente el 4-aminoestireno, que da lugar a una sal de diazonio tras una reacción de diazotación. La sal de diazonio reacciona con fenoles en medio acuoso a través de un acoplamiento diazoico, permitiendo su detección colorimétrica. Por su parte, el segundo material basa su capacidad sensora en la formación de polianilina y tiene lugar cuando una matriz polimérica cargada de anilina se encuentra en presencia de una atmósfera oxidante.

\subsection{Introducción}

Como se ha comentado en el Capítulo 1, uno de los objetivos principales de esta memoria consiste en el análisis en profundidad y mejora de la capacidad sensora de sistemas poliméricos en forma de filmes. En este capítulo se presentan dos trabajos de investigación que se han basado en este objetivo. En primer lugar, se describe la síntesis de un sensor polimérico colorimétrico capaz de detectar fenoles en medio acuoso. En segundo lugar, se presenta un material polimérico que detecta agentes oxidantes en fase gas mediante la formación de polianilina (PANI), que tiene lugar cuando el sensor se halla en presencia de estos agentes 
oxidantes. En este segundo caso la respuesta sensora es dual al producirse cambio de color (sensor colorimétrico) y también variación en la conductividad eléctrica (sensor resistivo). Esto constituye una mejora del dispositivo sensor al poder evaluar los resultados a través de dos procesos de transducción.

A continuación, se describen estos dos sistemas de detección poliméricos.

\subsection{Detección de fenoles}

\subsubsection{Introducción}

El fenol, o hidroxibenceno, y sus derivados son sustancias muy utilizadas en la industria y, por tanto, susceptibles de generar problemas derivados de su empleo y transformación, por lo que resulta interesante contar con sistemas de detección de estas especies.

Por ejemplo, el fenol se usa en la fabricación de resinas fenólicas y otros materiales poliméricos, como los policarbonatos y las resinas epoxi. También interviene en el proceso de producción del Nylon. Los derivados del fenol se utilizan también en la industria química, farmacéutica, médica y agrícola.

El objetivo concreto de este trabajo fue la detección de 13 fenoles cuya estructura se recoge en la Tabla 2.1. A continuación, se describen brevemente sus características.

Los clorofenoles son el grupo de fenoles más amplio y extendido en el medio ambiente. Existen un total de 19 clorofenoles. Estos compuestos provienen de fuentes naturales, de la acción de microorganismos y plantas, y también tienen un origen antropogénico, como es el caso de la degradación de pesticidas y biocidas. Herbicidas como el ácido 2,4-diclorofenoxiacético, el ácido 4-cloro-2metilfenoxiacético, o plaguicidas como el ácido 2,4,5-triclorofenoxiacético, dan lugar al degradarse a distintos clorofenoles. La toxicidad de estos compuestos está relacionada con su carácter hidrofóbico, que aumenta con el número sustituyentes cloro. Además, la posición de estos sustituyentes también afecta al grado de toxicidad, siendo más nocivos los compuestos sustituidos en meta 
que los sustituidos en para [1]. La fenhexamida, por su parte, se utiliza como pesticida y no se considera carcinógeno, aunque sí puede resultar tóxico en exposiciones prolongadas [2].

Tabla 2.1. Fenoles estudiados

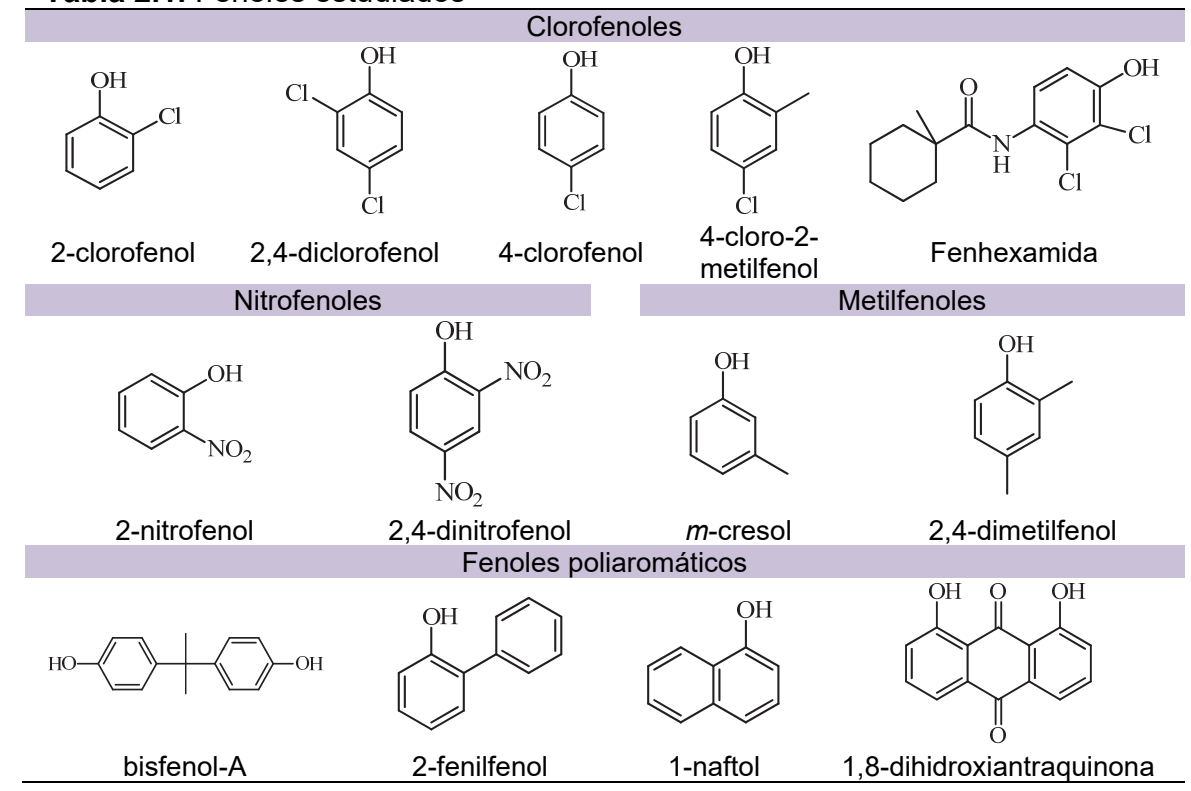

Los nitrofenoles son sustancias tóxicas y están clasificadas como peligrosas, aunque no se consideran cancerígenos. Estos compuestos, al igual que los clorofenoles, pueden originarse en la degradación de pesticidas como el 2-butil4,6-dinitrofenol (Dinoseb) o el 4,6-dinitro-2-metilfenol (DNOC). No hay estudios que hayan evaluado los efectos de los nitrofenoles sobre los seres humanos, pero los realizados con animales han demostrado que el 4-nitrofenol es más dañino que el 2-nitrofenol y sugieren que el 4-nitrofenol puede dar lugar a enfermedades de la sangre [3].

[1] J. Michałowicz, W. Duda, Polish J. of Environ. Stud. 2007, 16, 347-362.

[2] Pesticide fact sheet-Fenhexamid. https://www3.epa.gov/pesticides/chem_search/ reg_actions/registration/fs_PC-090209_20-May-99.pdf (Accessed 12 March 2019).

[3] Agency for Toxic Substances and Disease Registry (ATSDR),

https://www.atsdr.cdc.gov/substances/toxsubstance.asp?toxid=172 (Accessed 15 March 2019). 
Los bisfenoles, en particular, el bisfenol A, se utilizan como monómeros en la preparación de polímeros para su empleo en embalajes, barnices para la protección de latas de conservas y bebidas, filmes para envolver alimentos o envases. Existe una gran preocupación con la capacidad que presenta este compuesto para migrar del embalaje al alimento, o al líquido con el que está en contacto, ya que es un disruptor endocrino que posee afinidad por los receptores de los estrógenos, pudiendo producir efectos estrogénicos [4].

El 2-fenilfenol [5], también conocido como conservante E-231, es un fungicida de amplio espectro y desinfectante de utilización preventiva. Impide la aparición de podredumbres de origen fúngico durante el almacenamiento. Se relaciona con daños en el riñón, y se clasifica como sustancia que puede considerarse carcinogénica para el ser humano. La 1,8-dihidroxiantraquinona, o Dantron [6], se utiliza como laxante. En Estados Unidos su uso está prohibido por considerarse carcinogénico. En el Reino Unido su empleo solo se destina a pacientes terminales, como paliativo. Además, es un compuesto residual generado en el metabolismo de los hongos.

El $m$-cresol es un precursor de compuestos como el fenitrotión, insecticida organofosforado y acaricida, y el fentión, plaguicida rigurosamente restringido por ser dañino para la salud humana y el medio ambiente [7]. El 1-naftol es uno de los precursores del insecticida carbaril que resulta tóxico y carcinogénico para los humanos. Además, el 1-naftol tiene capacidad disruptora para las hormonas tiroideas [8].

[4] A. Juan-García, C. Gallego, G. Font, Rev. Toxicol. 2015, 32, 144-160.

[5] S. Tayama, N. Kamiya, Y. Nakagawa, Res. Genet. Toxicol. Environ. Mutagen. 1989, 223, 23-33.

[6] Report on Carcinogens, Fourteenth Edition

https://ntp.niehs.nih.gov/ntp/roc/content/profiles/danthron.pdf (Accessed 22 March 2019).

[7] T. Tsuda, S. Aoki, T. Inove, M. Kojima, Wat. Res. 1995, 29, 455-458.

[8] H. Sun, O. Shen, X. Xu, L. Song, X. Wang Toxicology, 2008, 249, 238-242. 


\subsubsection{Matriz polimérica sensora}

El material polimérico utilizado para la detección de los fenoles descritos en el apartado anterior proviene de la copolimerización la $N$-vinilpirrolidona (VP) y el metacrilato de metilo (MMA) como principales componentes de la matriz polimérica, así como una pequeña proporción de 4-aminoestireno $\left(\mathrm{SNH}_{2}\right)$. Este comonómero otorga la capacidad sensora al filme, previa diazotación del grupo amino. La polimerización se lleva a cabo en forma de filme, en estado sólido. El material presenta una buena manejabilidad tanto en seco como en hinchado, así como buena estabilidad, gracias a las propiedades que imparten al material la mezcla apropiada de los monómeros VP y MMA.

La reacción de diazotación, que como se ha mencionado se lleva a cabo sobre el propio filme en una reacción heterogénea, se describe a continuación.

\subsubsection{Reacción de diazotación. Sales de diazonio}

Las sales de diazonio son compuestos orgánicos muy utilizados en la industria de los colorantes y también son intermedios clave en reacciones de síntesis orgánica. Estos compuestos pueden ser alifáticos o aromáticos, siendo los segundos más estables debido a la deslocalización de la carga positiva del grupo diazonio por el sistema $\pi$ del anillo. Pese a esto, incluso las sales de diazonio aromáticas no son aislables, y se utilizan inmediatamente después de su preparación, que generalmente se lleva a cabo a un temperatura igual o inferior a $5^{\circ} \mathrm{C}$. Además, estos compuestos se degradan por radiación UV.

La reacción de diazotación se llevó a cabo por primera vez en 1860 por Peter Griess [9] y se basa en la transformación de un grupo amina en una sal de diazonio por reacción con nitrito de sodio en medio ácido, generalmente $\mathrm{HCl}$ o $\mathrm{H}_{2} \mathrm{SO}_{4}$ en exceso, lo que previene una diazotación parcial o reacciones de condensación.

[9] V. Heines, J. Chem. Educ. 1958, 35, 187-191. 
En nuestro caso, esta reacción se llevó a cabo directamente sobre el filme (química en estado sólido), sumergiéndolo durante 90 minutos en una disolución acuosa acidificada, que contenía nitrito de sodio. De esta manera, se obtiene un material polimérico sensor que contiene grupos diazonio laterales a la cadena macromolecular (cloruro de bencenodiazonio) que presenta muy buena estabilidad física y química. Este hecho es algo a remarcar ya que, como se ha mencionado previamente, las sales de diazonio no son aislables como moléculas discretas y se deben utilizar inmediatamente después de su preparación. Así, los filmes se pueden almacenar durante días en condiciones ambientales, incluso con exposición a la luz, sin sufrir ninguna degradación. Se puede inferir que la matriz polimérica ofrece un ambiente protector para las sales de diazonio, lo que es una muestra más de las ventajas de los polímeros sensores frente a otro tipo de materiales sensores, así como una mejora sustancial en lo referente al empleo de las sales de diazonio como sensores.

\subsubsection{Reacción sensora. Acoplamiento diazoico}

El material sensor que se ha sintetizado es un dosímetro químico, ya que el proceso de detección se basa en una reacción química irreversible. En este caso, la reacción es el acoplamiento diazoico, también llamado copulación de sales de diazonio. La respuesta sensora es colorimétrica al generarse un compuesto azo altamente coloreado anclado a la estructura macromolecular que conforma el filme sensor. El acoplamiento diazoico se da entre una sal de diazonio aromática y un compuesto aromático activado, y es por tanto una sustitución electrófila aromática. Las sales de diazonio aromáticas son electrófilos débiles, ya que la carga positiva del nitrógeno se deslocaliza en el anillo aromático. Por ello, es necesario que el nucleófilo esté activado, hecho que ocurre en los derivados de la anilina y los fenoles.

Estos compuestos activados presentan formas resonantes que nos indican las posiciones más activas para que se dé el acoplamiento. En el caso de los fenoles, y trabajando en medio básico, tenemos dos posibles posiciones de reacción: orto y para, siendo esta última la más favorable. Por tanto, los fenoles 
que se pueden detectar usando el filme polimérico sensor deben tener, al menos, una de estas posiciones libres.

El dispositivo sensor que aquí se presenta permite la detección sencilla de fenoles debido a la estabilidad química de la especie sensora (la sal de diazonio), estabilidad que se consigue gracias al entorno generado por la estructura polimérica.

\subsubsection{Sensor colorimétrico}

La cuantificación de la variación de color se lleva a cabo de dos formas. Por un lado, se ha utilizado la espectroscopia UV-Vis para el registro de los distintos espectros de absorción. Esta técnica, además, ha servido para fijar la cantidad de monómero de anclaje que se debe utilizar con cada fenol, ya que dependiendo del azo-compuesto formado se obtienen colores muy claros o muy intensos que saturan el equipo, así como para medir las cinéticas de reacción de diazotación y de acoplamiento diazoico.

Por otro lado, se ha utilizado la técnica basada en el análisis de los parámetros de color RGB a partir de fotografías tomadas del material sensor tras reaccionar con el fenol. Esta técnica es rápida, económica y no necesita de personal especializado, que es una de las ventajas de estos sistemas de detección [10].

\subsection{Detección de atmósferas oxidantes}

\subsubsection{Atmósferas oxidantes: $\mathrm{Cl}_{2}$ y $\mathrm{H}_{2} \mathrm{O}_{2}$}

$\mathrm{El} \mathrm{Cl}_{2}$ libre generado a partir de ácido hipocloroso $(\mathrm{HClO})$ o del hipoclorito $\left(\mathrm{ClO}^{-}\right)$ es un potente agente oxidante. El cloro gas se disuelve en agua básica $(\mathrm{NaOH})$ para dar lugar a hipoclorito sódico, que se usa habitualmente como desinfectante [11]. Su concentración en las aguas de consumo se debe controlar estrictamente, pues una baja concentración causa una desinfección insuficiente y una 
concentración excesiva conduce a productos tóxicos para el ser humano, como los trihalometanos. Por tanto, desde el punto de vista de la seguridad sanitaria su detección y cuantificación es relevante.

Además, el $\mathrm{Cl}_{2}$, o bertholita, se ha usado como agente de guerra química. Así, se utilizó por primera vez en la primera guerra mundial y más recientemente en la guerra de Irak del año 2007 [12].

Por su parte, la detección de $\mathrm{H}_{2} \mathrm{O}_{2}$ es importante en campos como la industria textil y del papel, minería, petroquímica y procesado alimentario, por no hablar del interés en su detección en el ámbito de la seguridad civil, pues es uno de los reactivos necesarios para la preparación de TATP, un potente explosivo utilizado en recientes ataques terroristas [13].

\subsubsection{Matrices poliméricas}

De igual forma que en la preparación del sensor de fenoles, para la detección de $\mathrm{Cl}_{2}$ y $\mathrm{H}_{2} \mathrm{O}_{2}$ se diseñó una matriz polimérica que permitiera obtener filmes con propiedades óptimas, tanto en seco como en hinchado, de fácil manejo y que a la vez fueran idóneas desde el punto de vista de la respuesta a los analitos de interés. En este sentido, las composiciones monoméricas adecuadas resultaron ser dos, una de ellas formada por la $\mathrm{N}$-vinilpirrolidona y metacrilato de metilo, y la otra por el acrilato de 2-hidroxietilo y el metacrilato de metilo. Se llevó a cabo la polimerización radical por vía fotoquímica para generar los dos filmes.

La novedad de este trabajo consiste en el uso de filmes vinílicos que, una vez cargados con anilina, permiten la detección de los agentes oxidantes mediante los cambios de color $\left(\mathrm{Cl}_{2}\right.$ y $\left.\mathrm{H}_{2} \mathrm{O}_{2}\right)$ y de conductividad eléctrica $\left(\mathrm{Cl}_{2}\right)$ que tienen lugar durante la polimerización oxidativa de la anilina contenida en los filmes.

Por eso, conviene en este punto hacer una pequeña consideración acerca de las características de la polimerización de la anilina para formar PANI. La PANI es

[12] M. Wiergowski, I. Sołtyszewski, J.S. Anand, M. Kaliszan, J.A. Wilmanowska, Z. Jankowski, M. Łukasike J. Forensic Leg. Med., 2018, 58, 82-86.

[13] B. Gokdere, A. Uzer, S. Durmazel, E. Ercağ, R. Apak Talanta 2019, 202, 402-410. 
uno de los polímeros conductores más conocidos y utilizados desde los años 70 del siglo pasado. Desde entonces se ha usado en múltiples aplicaciones, como por ejemplo en pinturas conductoras [14], circuitos electrónicos [15], almacenamiento de energía solar [16], supercapacitores flexibles [17] o tejidos inteligentes [18]. Este polímero es intrínsecamente conductor, presenta una gran estabilidad ambiental y unos valores de conductividad en estado dopado que pueden variar de entre $10^{-3}$ y $10^{2} \mathrm{~S} / \mathrm{cm}$, dependiendo de la extensión de la conjugación, el nivel de dopado y el tipo de dopante [19]. En el caso de la PANI el estado dopado hace referencia a un estado de oxidación intermedio, conocido como emeraldina, que se encuentra protonado formando la emeraldina sal. En cuanto a su estructura, la PANI está formada por la sucesión de monómeros de anilina con acoplamientos cabeza-cola en los que el nitrógeno de cada anilina se une en posición para con la siguiente molécula, como se aprecia en el Esquema 2.1. Esta regioregularidad permite que entre las cadenas se produzca un fuerte apilamiento $\pi$, lo que explica en parte la insolubilidad de este polímero en la mayoría de los disolventes de uso común, así como su difícil procesado.

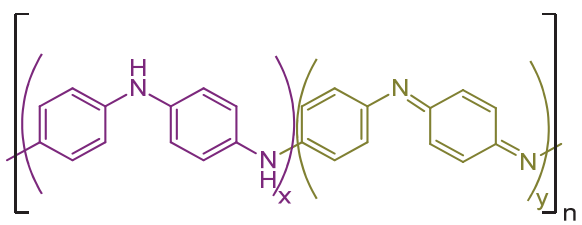

Esquema 2.1. Estructura de la PANI en sus distintos estados de oxidación sin protonar: leucoemeraldina $x=1 \mathrm{y}=0$; emeraldina $\mathrm{x}=0.5 \mathrm{y}=0.5$; pernigranilina $x=0 y=1$

[14] M. Hosoda, T. Hino, N. Kuramoto, Polym. Int. 2007, 56, 1448-1455.

[15] E.S. Matveeva, R. Díaz Calleja, V. Parkhutik, J. Non-Cryst. Solids. 1998, 235-237, 772-780.

[16] J. Duan, Y. Duan, Y. Zhao, Y. Wang, Q. Tang, B. HE, J. Energy Chem. 2018, 27, 742-747.

[17] G.-P. Hao, F. Hippauf, M. Oschatz, F.M. Wisser, A. Leifert, W. Nickel, N. Mohamed-Noriega, Z. Zheng S. Kaskel, ACSNano 2014, 8, 7138-7146.

[18] A.M. Grancarić, I. Jerković, V. Koncar, C. Cochrane, F.M. Kelly, D. Soulat, X. Legrand, J. Ind. Text. 2018, 48, 612-642.

[19] I.Y. Choi, J. Lee, H. Ahn, J. Lee, H.C. Choi, M.J. Park, Angew. Chem. Int. Ed. 2015, 54, 1049710501. 


\subsubsection{Respuesta sensora dual}

En el caso que se presenta, el estímulo frente al que reacciona el filme polimérico sensor es una atmósfera oxidante $\left(\mathrm{Cl}_{2} \circ \mathrm{H}_{2} \mathrm{O}_{2}\right)$. Con ambos compuestos se produce un cambio de color que se puede detectar a simple vista. Pero, además, si el agente oxidante es el $\mathrm{Cl}_{2}$, se genera la emeraldina protonada que presenta conductividad eléctrica. De esta manera se obtiene un material sensor con dos respuestas simultáneas (respuesta dual), haciendo que el proceso de detección sea mucho más fiable y fácil de seguir. El comportamiento del sensor se resume gráficamente en el Figura 2.1.

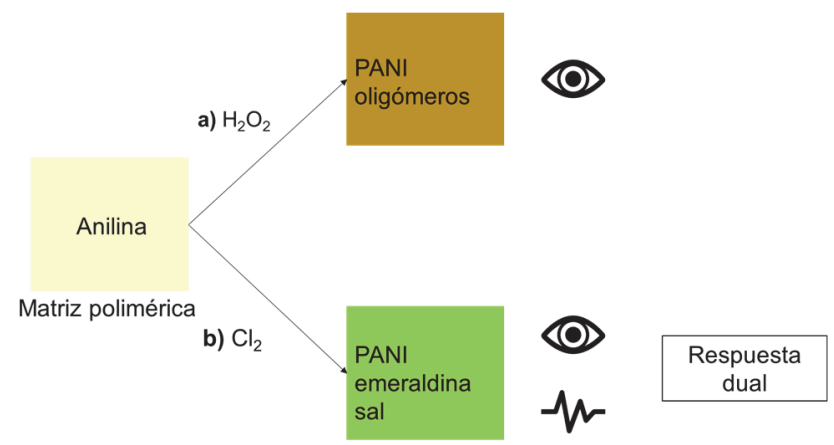

Figura 2.1. Respuesta frente a agentes oxidantes, polimerización oxidativa de la anilina: a) reacción con peróxido de hidrógeno para generar oligómeros de color marrón de PANI y, b) reacción con cloro para generar PANI verde (emeraldina sal) y eléctricamente conductora.

En cuanto a la respuesta colorimétrica, la formación de PANI produce cambios de color en el material sensor, que como en el caso de la detección de fenoles, se pueden seguir mediante espectroscopia de UV-Vis y también usando los parámetros de color RGB a partir de fotos digitales de este material.

En lo que respecta a una respuesta resistiva, el comportamiento del material sensor frente al estímulo se basa en una variación de la conductividad eléctrica del mismo, bien en forma de aumento o disminución. En nuestro caso, lo que se observa es un aumento de la conductividad eléctrica con el tiempo, que se debe a la formación del polímero conductor PANI en forma de emeraldina sal. A 
continuación, se explican los dos métodos que se han utilizado para cuantificar las variaciones de conductividad eléctrica que se dan en el polímero sensor.

El primer método es el sensor de 4 puntas. Este tipo de sensor se utiliza mucho para medir la resistividad de materiales semiconductores, especialmente cuando la muestra está en forma de capa fina depositada sobre un sustrato. Se compone de 4 puntas ordenadas en línea recta, separadas la misma distancia entre unas y otras. Se hace pasar una corriente constante entre las dos puntas de los extremos y se mide la caída de potencial que tiene lugar entre las dos puntas centrales. Para que la medida sea fiable, la resistividad del material debe ser uniforme en el área de medida. Además, la muestra debe ser plana y no presentar roturas.

El segundo tipo de sensor es el inductivo. Este se basa en el efecto inductivo, según el cual la corriente eléctrica alterna que pasa a través de una bobina genera un campo magnético variable $\left(B_{0}\right)$ que es capaz de interaccionar con el material sensor sobre el que se está generando la PANI conductora. A su vez, $B_{0}$ es capaz de inducir fuerzas electromotrices que generan corrientes internas en el material conductor que se está midiendo. Estas corrientes se denominan corrientes de Foucault, y dependen de la distancia al material conductor y del tamaño y composición del mismo. Las corrientes de Foucault generan un campo magnético $\left(\mathrm{B}_{\mathrm{i}}\right)$ que se opone al campo magnético $\mathrm{B}_{0}$. Siendo el campo magnético resultante $B_{r}$ menor que $B_{0}$. De esta manera se mide el esfuerzo que realiza el sistema para mantener $\mathrm{B}_{\mathrm{r}}$ constante.

La ventaja que presenta este sensor frente al sensor de cuatro puntas es que no se necesita un contacto físico entre el material sensor y el dispositivo de medida, lo que hace que se obtenga información sobre la evolución del proceso de detección sin perturbarlo. Por otra parte, el inconveniente de este método es que no proporciona medidas absolutas, sino únicamente da información de las variaciones relativas, por lo que es necesario combinar los dos tipos de sensores para obtener datos fiables acerca de la evolución de la conductividad eléctrica en el material sensor. 


\subsection{Resultados}

A continuación, se describen los resultados obtenidos a través de la transcripción íntegra de los trabajos publicados:

* Polymer films containing chemically anchored diazonium salts with longterm stability as colorimetric sensors

* Easy and inexpensive method for the visual and electronic detection of oxidants in air by using vinylic films with embedded aniline 
Polymer films containing chemically anchored diazonium salts with long-term stability as colorimetric sensors 



\title{
Polymer films containing chemically anchored diazonium salts with long-term stability as colorimetric sensors
}

Saúl E. Bustamante ${ }^{b}$, Saúl Vallejos ${ }^{a, *}$, Blanca Sol Pascual-Portal ${ }^{a}$, Asunción Muñoz ${ }^{a}$, Aránzazu Mendía ${ }^{a}$, Bernabé L. Rivas ${ }^{b, *}$, Félix C. García ${ }^{a}$, José M. García ${ }^{a}$.

a Departamento de Química, Facultad de Ciencias, Universidad de Burgos. Plaza de Misael Bañuelos s/n, 09001 Burgos, Spain

${ }^{b}$ Polymer Department, Faculty of Chemistry, University of Concepción, Casilla 160-C, Concepción, Chile

\section{Graphical abstract}

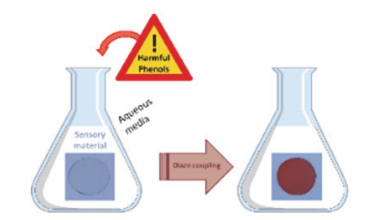

\begin{abstract}
We have prepared polymeric films as easy-to-handle sensory materials for the colorimetric detection and quantification of phenol derivatives (phenols) in water. Phenols in water resources result from their presence in pesticides and fungicides, among other goods, and are harmful ecotoxins. Colorless polymeric films with pendant diazonium groups attached to the acrylic polymer structure were designed and prepared for use as sensory matrices to detect phenolderived species in water. Upon dipping the sensory films into aqueous media, the material swells, and if phenols are present, they react with the diazonium groups of the polymer to render a highly colored azo group, giving rise to the recognition phenomenon. The color development can be visually followed for a qualitative determination of phenols. Additionally, quantitative analysis can be performed by two different techniques: a) by using a UV-vis spectrophotometer (limit of detection of $0.12 \mathrm{ppm}$ for 2-phenylphenol) and/or b) by using a smartphone with subsequent RGB analysis (limit of detection of 30 ppb for 2-phenylphenol).
\end{abstract}




\section{Introduction}

Phenols are harmful ecotoxins with both natural [1] and anthropogenic origins. They are mutagenic and carcinogenic products, exhibit hepato- and hematotoxic activity toward all kinds of living beings, and their elimination through oxidation and/or degradation processes has been widely studied [2-6]. From a human activity viewpoint, environmental pollution related to phenol derivatives comes from the petrochemical, chemical and pharmaceutical industries that produce goods in which phenols are used, such as drugs, household chemicals, dyes, and polymers. In particular, the presence of phenols in the ecosystem is worryingly related to the use and degradation of pesticides and biocides (the germicidal activity of phenol was discovered in 1865 by Joseph Lister). Among all kinds of phenolic products, the most widespread are chlorophenols, formed from the chlorination of mono- and polyaromatic phenols present in the water and soil. Other relevant phenol-derived families are nitrophenols, alkylphenols, bisphenols and aminophenols [7-9].

Currently, phenols in the environment are detected by GC/MS (gas chromatography coupled with mass spectrometry) or HPLC (high-performance liquid chromatography) coupled to different detectors [10]. These techniques require, in addition to expensive instrumentation and trained personnel, laborious and time-consuming microextraction steps (SPME or LPME) $[11,12]$. Additionally, biosensors have been proposed [12,13], along with a number of electrochemical methods [14-16], including the use of quantum dots [17]. Systems based on colorimetric or fluorimetric detection of different contaminants are a good alternative to these conventional methods [18-24].

We propose the in situ visual detection and quantification of phenols in aqueous media by untrained personnel by using inexpensive and rapid colorimetric sensory films. These sensory films are acrylic polymers with stable diazonium salts chemically anchored to the polymeric structure. The films swell in water, where the phenols penetrate by diffusion before undergoing azo coupling with the 
diazonium salts to give the strongly colored azo compounds. The azo coupling reaction is the well-known basis for the preparation of synthetic azo dyes, which have been intensively used since the third quarter of the 19th century [25-28]. In this regard, the noteworthy stability under laboratory temperature and light conditions of polymer materials with diazonium groups should be mentioned compared to that of the discrete benzenediazonium chloride derivatives, which are interesting chemical species used in the preparation of a number of chemicals that decompose above $5{ }^{\circ} \mathrm{C}$ and, accordingly, are prepared in ice-cold solutions and used immediately, without isolation.

\section{Experimental}

\subsection{Materials}

All materials and solvents were commercially available and used as received unless otherwise indicated. The following materials and solvents were used: sodium hydroxide (VWR, 99\%), 2,2'-azobis(2-methylpropionitrile) (AIBN) (Aldrich, 98\%), 1-vinyl-2-pyrrolidone (VP) (Aldrich, 99\%), methylmethacrylate (MMA) (Aldrich, 99\%), 4-aminostyrene (Aldrich, 99\%), sodium nitrite (VWR, 99.5\%), m-cresol (Alfa Aesar, >99\%), 2-chlorophenol (Alfa Aesar, >99\%), bisphenol-A (Acros Organics, >97\%), 2-nitrophenol (Alfa Aesar, >98\%), 2,4dinitrophenol (Alfa Aesar, >96\%), fenhexamid (Aldrich, 99\%), 2,4-dichlorophenol (Alfa Aesar, >99\%), 4-chlorophenol (Alfa Aesar, >99\%), 4-chloro-2-methylphenol (Aldrich, 97\%), 2,4-dimethylphenol (Aldrich, 98\%), 2-phenylphenol (Aldrich, 99\%); 1-naphthol (Aldrich, >99\%), and 1,8-dihydroxyanthraquinone (Aldrich, $96 \%)$.

In the tests carried out with the product, the commercial pesticide DECCO ${ }^{\circledR}$ OPP a fungicide widely used for postharvest treatment of fungi causing rot (Penicillium spp., Rhizopus spp.), mainly in citrus fruits, was used. This pesticide is formulated as an emulsifiable concentrate and contains as an active component 2phenylphenol (concentration: $10 \% \mathrm{w} / \mathrm{v}(100 \mathrm{~g} / \mathrm{L})$ ), in addition to other elements in 
very low concentrations such as Si (15080.5 ppb), Mn (1.8 ppb), Zn (622.3 ppb), $\mathrm{Pd}(49.4 \mathrm{ppb})$ and $\mathrm{Ba}(7.2 \mathrm{ppb})$.

\subsection{Measurements and instrumentation}

The optical analysis was carried out by taking digital pictures of the sensory films with a smartphone Samsung J7 prime after immersion in aqueous media with different concentrations of phenols. This procedure allowed the quantification of each phenol concentration using the "B" (blue) and the "R" (red) parameters of the RGB (red, green and blue) color model $[29,30]$. The "B" and "R" color parameters for each disc were obtained immediately after taking the pictures with the smartphone using the ColorMeter app to automatically average the data over a $11 \times 11$ (121) pixel area. Due to the possible influence of ambient light on the image quality, a homemade retro-illumination box was used, which allowed good repeatability for the imaging analysis [30]. In addition, the UV-vis spectra were recorded using a U-3900 UV/vis spectrophotometer.

The starting materials were thermally and mechanically characterized using thermogravimetric analysis (TGA, 10-15 mg of sample under a synthetic air and nitrogen atmosphere with a TA Instruments Q50 TGA analyzer at $\left.10{ }^{\circ} \mathrm{C} \mathrm{min}-1\right)$, differential scanning calorimetry (DSC, 10-15 mg of sample under nitrogen atmosphere with a TA Instruments Q200 DSC analyzer at $20{ }^{\circ} \mathrm{C} \mathrm{min}-1$ ), and tensile properties analysis $(5 \times 9.44 \times 0.122 \mathrm{~mm}$ samples using a Shimadzu EZ Test Compact Table-Top Universal Tester at $1 \mathrm{~mm} \mathrm{~min}^{-1}$ ).

The infrared spectra of the sensor films were recorded using a synchrotron light beam coming from a particle accelerator (ALBA synchrotron, Barcelona-Spain), utilizing the FTIRM (Fourier transform infrared microspectroscopy) technique in transmission mode, employing a Hyperion 3000 microscope coupled to the Vertex 70 spectrometer (Bruker, Germany, 4000-400 cm-1 ). High-resolution electron-impact mass spectrometry (El-HRMS) was carried out on a Micromass AutoSpect Waters mass spectrometer (ionization energy: $70 \mathrm{eV}$; mass resolving power: $>10000)$. The ${ }^{1} \mathrm{H}$ and ${ }^{13} \mathrm{C}$ NMR spectra were recorded with a Varian Inova 
400 spectrometer operating at 399.92, and $100.57 \mathrm{MHz}$, respectively, with deuterated dimethyl sulfoxide as the solvent.

The weight percentage of water taken up by the films upon soaking in pure water at $20{ }^{\circ} \mathrm{C}$ until reaching equilibrium (water-swelling percentage, WSP) was obtained from the weight of a dry sample film $\left(\omega_{d}\right)$ and its water-swelled weight $\left(\omega_{s}\right)$ using the following expression: WSP $=100 \times\left[\left(\omega_{s}-\omega_{d}\right) / \omega_{d}\right]$.

\subsection{Polymer synthesis}

The starting material was obtained by radical copolymerization of the different monomers: vinylpyrrolidone (VP) as the hydrophilic monomer, methylmethacrylate (MMA) as the hydrophobic monomer, and 4-aminostyrene $\left(\mathrm{SNH}_{2}\right)$ as the anchorage monomer. The bulk radical polymerization was carried out in a silanized glass mold (100 $\mu \mathrm{m}$ thick) in an oxygen-free atmosphere at 60 ${ }^{\circ} \mathrm{C}$ overnight. In regard to the molar ratio of the monomers, this can be adjusted for different purposes. In our case, the colorimetric response of the material toward phenols was modulated by adjusting this molar ratio, i.e., 49.975/49.975/0.05 (VP/MMA/SNH $\left.{ }_{2}\right)$ ( $F_{005}$, for preparing sensory films for sensing phenols that produce strong colors upon interaction with the sensory film), 49.875/49.875/0.25 (VP/MMA/SNH $\left.{ }_{2}\right)\left(\mathrm{F}_{025}\right.$, for preparing sensory films for detecting phenols that produce soft colors upon interaction with the sensory film), and 45/45/10 (VP/MMA/SNH 2$)\left(\mathbf{F}_{\mathbf{1 0}}\right.$, for FT-IR characterization. The high molar content of $\mathrm{SNH}_{2}$ allows for following by infrared spectroscopy both the preparation of the sensory material and the sensing mechanism). The chemical structure of the films used to prepare the sensory materials is depicted in Scheme 1. Additionally, the thermally initiated bulk polymerization procedure for polymers prepared with VP results in crosslinked materials [31], which limits conventional NMR or GPC analysis. Thus, we have prepared a linear polymer with the same monomer feed ratio. The ${ }^{1} \mathrm{H}$ NMR analysis of the linear polymer, which is soluble, confirms that the structural units conforming the polymers structure corresponds with the ratio of monomers used to prepare the macromolecule. The synthesis and characterization of the linear polymer is showed in ESI, SectionS4. 


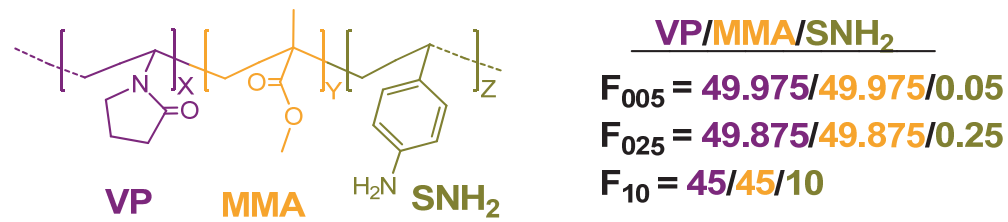

Scheme 1. Chemical structure of the polymer films.

The sensory materials were prepared from the films $\mathbf{F}_{005}, \mathbf{F}_{025}$ or $\mathbf{F}_{10}$ with a solidstate reaction by dipping $8 \mathrm{~mm}$ discs of these films into $10 \mathrm{~mL}$ of an aqueous solution containing $1 \mathrm{~mL}$ of $\mathrm{HCl}(37 \%)$ and $40 \mathrm{mg}$ of $\mathrm{NaNO}_{2}$ at RT for $90 \mathrm{~min}$ (see Scheme 2). In this way, materials with pendant benzenediazonium salt motifs $\left(F_{005} B, F_{025} B\right.$ and $\left.F_{10} B\right)$ were readily prepared.

\section{Results and discussion}

The reactions between phenols and diazonium salts in basic aqueous media have been studied for decades [32,33]. These reactions give rise to highly colored products that are commonly used in the pigments and dyes industry.

In this work, we prepared polymeric film materials from two main commercially available comonomers (VP, MMA) and a third comonomer $\left(\mathrm{SNH}_{2}\right)$, added in small ratios to the others, which acts as an anchorage monomer providing pendant aniline groups to the polymeric structure. The main comonomers (VP, hydrophilic; MMA, hydrophobic) provide polymeric films with the correct hydrophilicity balance needed for sensing purposes in aqueous media, i.e., the ability to swell in water without losing mechanical behavior in the swollen state $[34,35]$.

As shown in Scheme 2, the amine group of the aniline moieties reacts with sodium nitrite in acidic aqueous media to produce the sensory materials, with pendant benzenediazonium groups $\left(F_{005} \mathbf{B}, \mathbf{F}_{025} \mathbf{B}\right.$ and $\left.\mathbf{F}_{10} \mathbf{B}\right)$. These colorless materials are stable for weeks and are capable of detecting phenols in basic aqueous media, with low limits of detection (LOD) and quantification (LOQ), by the reaction of the benzenediazonium groups with the target phenols to produce colored films, where the colors come from the formation of pendant azo groups 
$\left(\mathbf{F}_{005} \mathbf{C}, \mathbf{F}_{025} \mathbf{C}\right.$ and $\left.\mathbf{F}_{10} \mathbf{C}\right)$. This chemical reaction is intrinsically non-reversible; thus, the sensor is actually a chemical dosimeter.
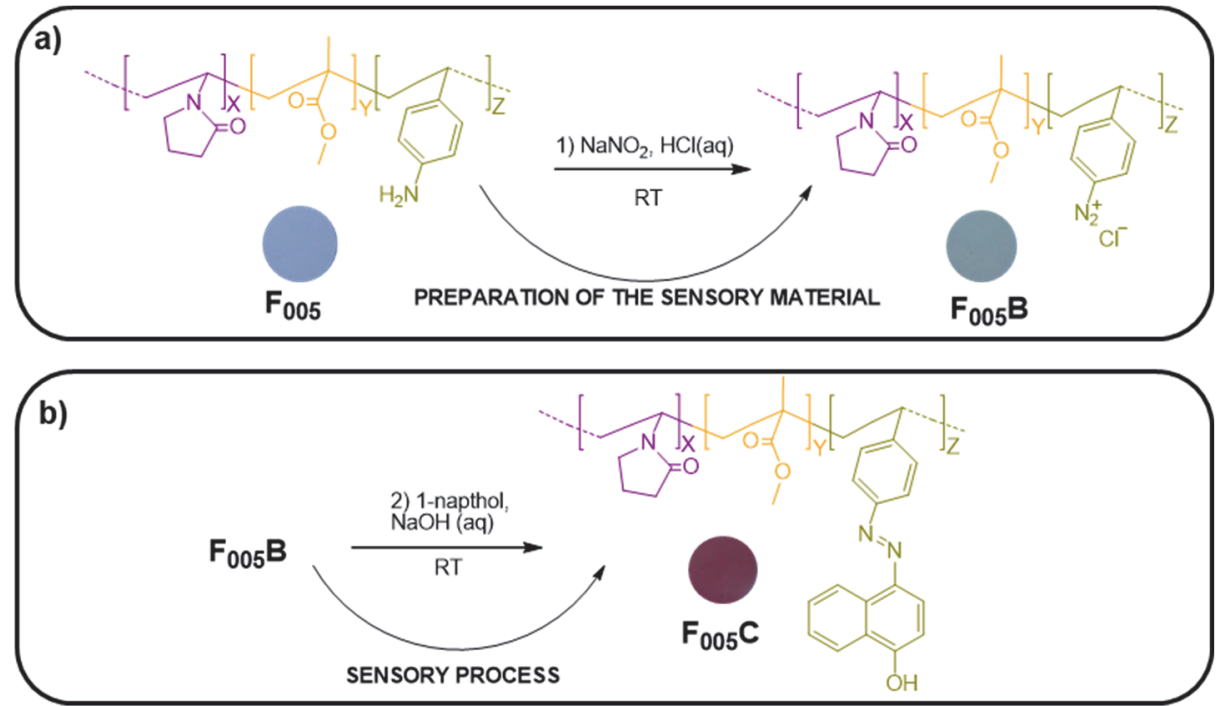

Scheme 2. Example of the preparation of the sensory films (a) by dipping an $8 \mathrm{~mm}$ disc of the film into $10 \mathrm{~mL}$ of an aqueous solution containing $1 \mathrm{~mL}$ of $\mathrm{HCl}(37 \%)$ and $40 \mathrm{mg}$ of $\mathrm{NaNO}_{2}$ at RT for $90 \mathrm{~min}$, and (b) example of the sensing process for 1-naphthol carried out by dipping the sensory film into $10 \mathrm{~mL}$ of an aqueous solution containing 40 $\mathrm{mg}$ of $\mathrm{NaOH}$ and $130 \mathrm{mg}$ of 1 -naphthol.

\subsection{Water uptake}

Usually known as the water swelling percentage (WSP) [33,34], water uptake is a critical parameter for these kinds of materials and is intimately related to both the manageability properties and the transport of water soluble target species into the swelled sensory materials, where the chemical reactions that give rise to sensing take place. Thus, the higher the water uptake is, the higher the transport rate and, at the same time, the worse the manageability properties. Thus, it is very important to achieve the best balance between both properties. For this application, $\mathbf{F}_{005}, \mathbf{F}_{025}$, and $\mathbf{F}_{10}$ exhibited WSP of $64 \%, 54 \%$ and $20 \%$ respectively, with good manageability in the water-swollen state and rapid response of the sensory materials derived from them, especially $\mathbf{F}_{005}$ and $\mathbf{F}_{025}$. 


\subsection{Thermal and mechanical analysis}

The thermogravimetric analysis (TGA) of the materials was carried out under an inert (nitrogen) atmosphere at a scan rate of $10{ }^{\circ} \mathrm{C} \mathrm{min}-1$ by measuring samples of $10-15 \mathrm{mg}$ of film for $\mathbf{F}_{005}, \mathbf{F}_{025}$ and $\mathbf{F}_{10}$. The data for the $5 \%\left(T_{5}\right)$ and $10 \%\left(T_{10}\right)$ weight loss under nitrogen atmosphere were $\left(\mathrm{T}_{5} / \mathrm{T}_{10}\right) 353^{\circ} \mathrm{C} / 364^{\circ} \mathrm{C}, 353^{\circ} \mathrm{C} / 366$ ${ }^{\circ} \mathrm{C}$, and $311^{\circ} \mathrm{C} / 370{ }^{\circ} \mathrm{C}$ respectively. The $T_{5}$ of $F_{10}$ is significantly lower due to the high content of aniline moieties derived from the $\mathrm{SNH}_{2}$ monomer, as is graphically depicted in ESI, Section S1.

The glass transition temperatures $(\mathrm{Tg})$ of the materials were calculated by DSC analysis at $20{ }^{\circ} \mathrm{C} \mathrm{min}-1$, obtaining values for $\mathbf{F}_{005}, \mathbf{F}_{025}$ and $\mathbf{F}_{10}$ at approximately $140{ }^{\circ} \mathrm{C}$, i.e., the content of $\mathrm{SNH}_{2}$ does not meaningfully influence the $\mathrm{Tg}$.

The Young's modulus values for $\mathbf{F}_{005}, \mathbf{F}_{025}$ and $\mathbf{F}_{10}$ were obtained by mechanical analysis of 10 strips of each material ( $5 \mathrm{~mm}$ of width, $30 \mathrm{~mm}$ length, and 100-120 $\mu \mathrm{m}$ thick) after drying at $60^{\circ} \mathrm{C}$ for $1 \mathrm{~h}$. The speed of the method was $5 \mathrm{~mm} \mathrm{~min}^{-1}$, with a gauge length of $10 \mathrm{~mm}$. Higher molar ratios of $\mathrm{SNH}_{2}$ increased the Young's modulus, obtaining values for $F_{005}, F_{025}$, and $F_{10}$ of 494,566 , and $873 \mathrm{MPa}$ respectively.

\subsection{Response time}

The prepared materials are intended to be used as sensors in real-world applications; thus, the response times must be as low as possible. We have studied the response times of a number of sensory films in previous works [30, $33,36]$, and this parameter depends on multiple variables, such as the thickness of the films, the molar ratio of the sensory motifs, and the hydrophilicity of the material. For example, the higher the molar ratio of the sensory motif is, the lower response time, and complementary, the higher the WSP is, the lower the response time. In this case, we worked with $100 \mu \mathrm{m}$ thickness films with a WSP between 20 and $60 \%$, depending on the molar ratio of sensory motif provided by films prepared from 0.05 to $10 \%$. The response times for $\mathbf{F}_{005} \mathbf{B}, \mathbf{F}_{025} \mathbf{B}$, and $\mathbf{F}_{10} \mathbf{B}$ are 120,5 , and 3 minutes, respectively (additional information in ESI, Section 
S2). Considering the economic aspects related to the use of widely available commercial comonomers (VP and MMA), the optimal material for this application is $\mathbf{F}_{025} \mathbf{B}$. Table 1 shows the figures of merit for comparing the performance of this sensory material with other techniques and methods for the detection of phenols.

Table 1 Comparative table of different phenol analytical methods.

\begin{tabular}{|c|c|c|c|c|c|c|}
\hline Sensor & $\begin{array}{l}\text { Cost of the } \\
\text { analyses/ } \\
\text { materials }\end{array}$ & $\begin{array}{l}\text { Detection } \\
\text { method }\end{array}$ & $\begin{array}{l}\text { Response } \\
\text { Time (min) }\end{array}$ & $\begin{array}{l}\text { LOD } \\
\text { (ppm) }\end{array}$ & $\begin{array}{c}\text { Naked-eye } \\
\text { detection }\end{array}$ & Ref. \\
\hline I & High & UV-vis & 5.00 & $<0.005$ & Yes & [37] \\
\hline II & Low & $\begin{array}{c}\text { SPEM/ATR- } \\
\text { IR }\end{array}$ & 20.0 & $<5.47$ & No & [38] \\
\hline III & High & GC-MS & ND & $<159$ & No & [39] \\
\hline IV & High & GC-FID & 30.0 & $<50$ & No & [40] \\
\hline V & High & HPLC-ED & 6.00 & $<3.48$ & No & [41] \\
\hline VI & High & HPLC-DAD & 9.56 & ND & No & [42] \\
\hline VII & High & CE & ND & $<0.05$ & No & [43] \\
\hline $\mathrm{F}_{025} \mathrm{~B}$ & Low & UV-vis & 3.33 & $0.12^{\mathrm{a}}$ & Yes & $\begin{array}{l}\text { This } \\
\text { work }\end{array}$ \\
\hline$F_{025} B$ & Low & $\begin{array}{l}{ }^{*} \text { Digital } \\
\text { picture }\end{array}$ & 3.33 & $0.03^{b}$ & Yes & $\begin{array}{l}\text { This } \\
\text { work }\end{array}$ \\
\hline
\end{tabular}

\subsection{Stability of the sensory materials}

To study the stability of the formed diazonium salt moieties within the material, we prepared 60 discs of $F_{005} \mathbf{B}$ ( $8 \mathrm{~mm}$ diameter) and kept them wet (water swollen) in commercial zipper storage bags at room temperature and without special care (without protecting from light). To test the performance of the material as a phenol sensor over time, three discs were dipped into $10 \mathrm{~mL}$ of an aqueous solution of $\mathrm{NaOH}(0.1 \mathrm{M})$ and 1-naphthol $(0.01 \mathrm{M})$ for $1 \mathrm{~h}$ at different times (up to 13 days). The discs were thoroughly washed with an aqueous solution of $0.1 \mathrm{M} \mathrm{NaOH}$ before taking a photograph with a smartphone to study its color. The results of the three discs tested at each timepoint were averaged. The response of the material was virtually the same over the testing period (13 days), as shown in Fig.1. Accordingly, the benzenediazonium salt motifs are stable within the material, and this result is noteworthy because these types of salts are considered inherently unstable and used without isolation in conventional organic chemistry. 


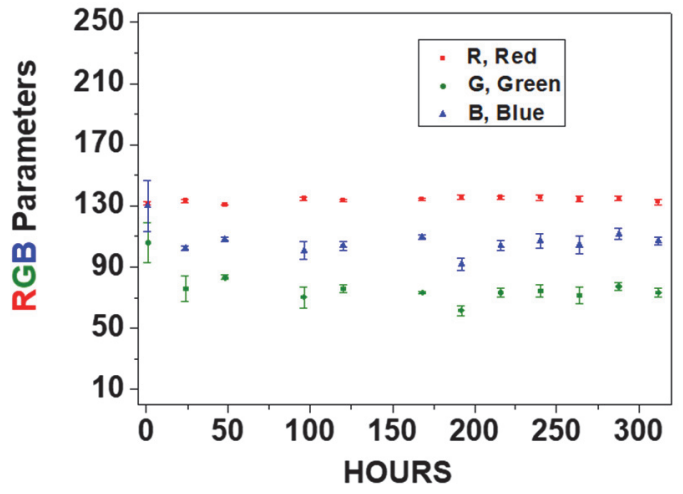

Fig. 1. R (red), G (green), and B (blue) parameters defining the digital color of the film, $\mathbf{F}_{005} \mathbf{B}$, after storage for different amounts of time and then submergence in an aqueous solution of phenols. The stored $8 \mathrm{~mm}$ discs of $\mathbf{F}_{005} \mathbf{B}$ were dipped in $10 \mathrm{~mL}$ of aqueous solution of $\mathrm{NaOH}(0.1 \mathrm{M})$ and 1-naphthol $(0.01 \mathrm{M})$. The pictures were taken with a conventional smartphone and the RGB parameters defining the color of each film were measured. (For interpretation of the references to color in this figure legend, the reader is referred to the web version of this article.)

\subsection{Characterization of the solid-state reaction}

Infrared spectra were collected using synchrotron radiation on $10 \mu \mathrm{m}$ thick films of $F_{10}$ and $F_{10} \mathbf{C}$ (1-naphthol), obtained from the interaction of $F_{10}$ with 1-naphthol. The band observed between 2250 and $2300 \mathrm{~cm}^{-1}$ in $\mathbf{F}_{10} \mathbf{B}$ corresponds with the stretching of $\mathrm{N} \equiv N$, whereas the observed band centered at $1576 \mathrm{~cm}^{-1}$ in the $\mathrm{F}_{10} \mathrm{C}$ (1-naphthol) spectrum confirms the formation of the diazo compound (see Fig. 2). 

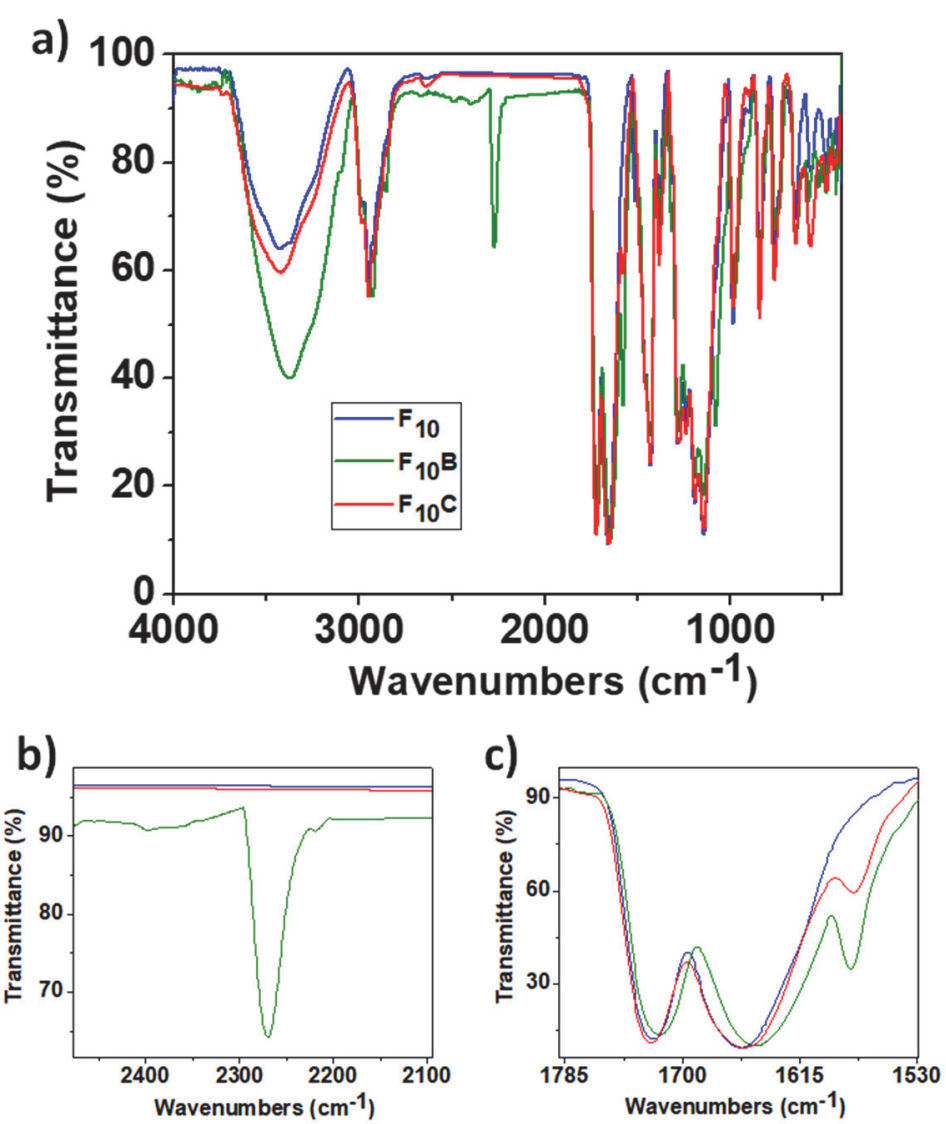

Fig. 2. a) FT-IR spectra of the sensory materials $\mathbf{F}_{\mathbf{1 0}}, \mathbf{F}_{\mathbf{1 0}} \mathbf{B}$ and $\mathbf{F}_{10} \mathbf{C}$ (1-naphthol); b) and c) Expansion of interesting regions.

Additionally, we prepared and characterized a model compound from $p$-toluidine and 1-naphthol under the same conditions, obtaining high yield and purity. The chemical characterization of the model is described in ESI, Section S3. To further study the material, we performed various SEM measurements on the surface of the films, but we did not find remarkable results due to the dense nature of the films. 
Table 2. Tested phenols and their uses.

\begin{tabular}{|c|c|c|}
\hline Phenol derivate & Use & Ref. \\
\hline 2,4-dimethylphenol & Pesticide & {$[44]$} \\
\hline fenhexamid & Fungicide & [45] \\
\hline 2-phenylphenol & Fungicide & {$[46]$} \\
\hline 1-naphthol & $\begin{array}{l}\text { Derived from the degradation of the pesticide } \\
\text { carbaryl. }\end{array}$ & {$[47,48]$} \\
\hline 1,8-dihydroxiantraquinone & Pesticide & [49] \\
\hline 2-chlorophenol & Pesticide & {$[50,51]$} \\
\hline 4-chlorophenol & Pesticide & {$[49,50]$} \\
\hline 2,4-dichlorophenol & $\begin{array}{l}\text { Derived from the degradation of the pesticide } \\
2 \text {-(2,4-dichlorophenoxy)acetic acid }\end{array}$ & {$[49,50]$} \\
\hline 2-methyl-4-chlorophenol & $\begin{array}{l}\text { Derived from the degradation of the pesticide } \\
\text { MCPA }\end{array}$ & [49] \\
\hline 2-nitrophenol & Byproduct in the synthesis of pesticides & [7] \\
\hline 4-nitrophenol & Byproduct in the synthesis of pesticides & {$[52]$} \\
\hline 2,4-dinitrophenol & Byproduct in the synthesis of dyes & [7] \\
\hline bisphenol $\mathrm{A}$ & Used in polymers for the alimentary industry & [53] \\
\hline
\end{tabular}

\subsection{Phenol detection performance}

We decided to test the performance of the sensory materials using 13 of the most common harmful phenols in pesticides, fungicides and other applications (see Table 2).

Thus, aqueous solutions $(\mathrm{NaOH} 0.1 \mathrm{M})$ of each phenol at different concentrations were prepared. Discs ( $8 \mathrm{~mm}$ diameter) of $\mathbf{F}_{005} \mathbf{B}$ were dipped into $10 \mathrm{~mL}$ of each phenol solution at room temperature for $60 \mathrm{~min}$. After that, the discs were thoroughly washed with aqueous $\mathrm{NaOH}(0.1 \mathrm{M})$ and photographed with a smartphone, and their UV-vis was recorded. Fig. 3 shows, as an illustrative example, the results for sensing 1-naphthol. Note that preliminary interference tests with metal cations and organic/inorganic anions were performed as depicted in previous work [30], and no relevant results were observed.

Fig. 4 shows the colorimetric response of sensory materials for the analyzed phenols. When the colorimetric response was not clearly visible with $\mathbf{F}_{005} \mathbf{B}$, a material with a higher concentration of the sensory motifs was used $\left(\mathbf{F}_{025} \mathbf{B}\right)$. 
A summary of the performance of each sensory material in terms of the LOD and LOQ for each studied phenol is shown in Table 3 (additionally, the individual RGB and UV-vis data and analysis of each phenol is shown in the ESI, Section S6).

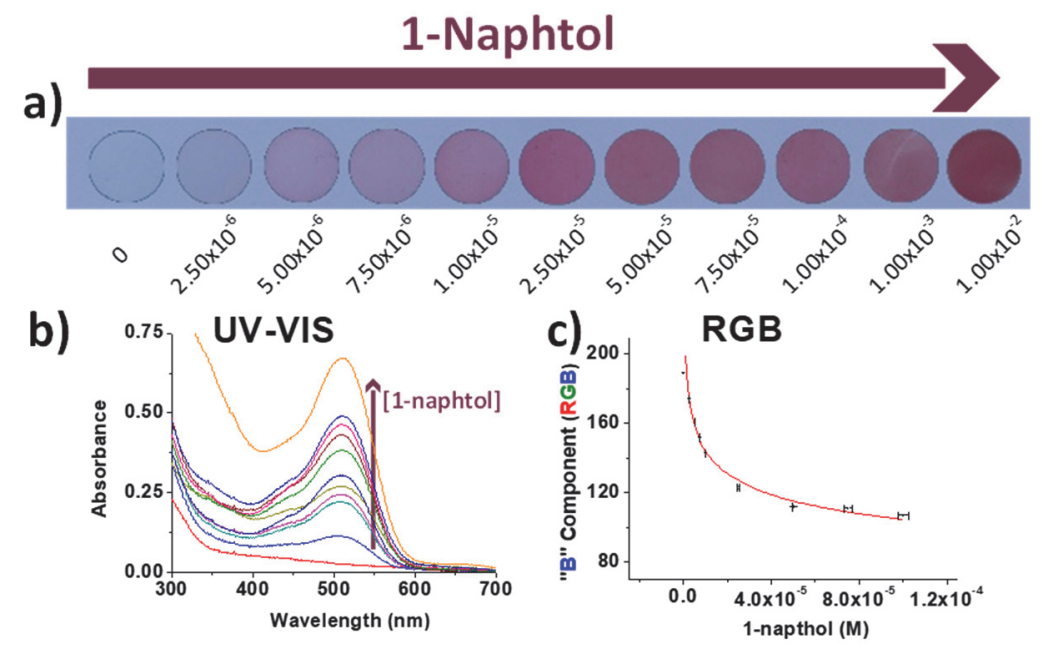

Fig. 3. a) Digital photograph of $F_{005}$ discs after immersion for $60 \mathrm{~min}$ at $\mathrm{RT}$ in aqueous solutions $(\mathrm{NaOH} 0.1 \mathrm{M})$ containing concentrations of 1-naphthol between $2.5 \times 10^{-6}$ and $1.00 \times 10^{-2} \mathrm{M}$; b) UV-vis spectra obtained from the discs (LOD and LOQ of $8.44 \times 10^{-7}$ $\mathrm{M}$ and $2.57 \times 10^{-6} \mathrm{M}$, respectively); c) titration curve for the blue component (RGB) of the discs (LOD and LOQ of $1.25 \times 10^{-6} \mathrm{M}$ and $3.80 \times 10^{-6} \mathrm{M}$, respectively; the blue component is not sensitive to higher concentrations of 1-naphtol, which are neither depicted nor used in curve fitting). (For interpretation of the references to color in this figure legend, the reader is referred to the web version of this article.) 


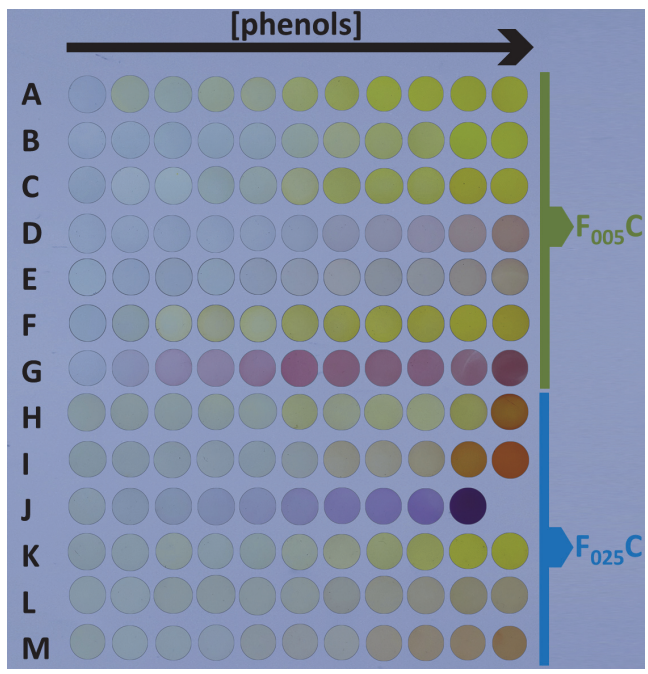

Fig. 4. Color matrix of sensory discs after being in contact with phenols in water. A set of vials with solutions of aqueous $0.1 \mathrm{M} \mathrm{NaOH}$ and varying phenol concentrations was freshly prepared, and one disc ( $8 \mathrm{~mm}$ diameter) of $\mathbf{F}_{005} \mathbf{B}$ or $\mathbf{F}_{025} \mathbf{B}$ was dipped into each solution for 60 min at RT. The UV-vis spectra and RGB parameters of each sensory disc were obtained (see the ESI, Section S6). F005B discs were dipped into solutions with phenol concentrations ranging from $2.5 \times 10^{-6} \mathrm{M}$ to $1 \times 10^{-2} \mathrm{M}$ to obtain F005C discs: (A) m-cresol, (B) 2-chlorophenol, (C) bisphenol-A, (D) 4-chloro-2-methylphenol, (E) 2,4-dimethylphenol, (F) 2-phenylphenol and (G) 1-naphthol. $\mathbf{F}_{025} \mathbf{B}$ discs were dipped into solutions with phenol concentrations ranging from 2.5 $\times 10^{-6} \mathrm{M}$ to $1 \times 10^{-2} \mathrm{M}$ to obtain $\mathrm{F}_{025} \mathrm{C}$ discs: (H) 2,4-dinitrophenol, (I) 4-chlorophenol and (J) 1,8-dihydroxyanthraquinone. $\mathbf{F}_{025} \mathbf{B}$ discs were dipped into solutions with phenols concentrations ranging from $1 \times 10^{-5} \mathrm{M}$ to $1 \times 10^{-2} \mathrm{M}$ to obtain $\mathbf{F}_{025} \mathrm{C}$ discs: $(\mathrm{K})$ 2-nitrophenol, (L) fenehexamid and (M) 2,4-dichlorophenol.

Table 3. Limit of detection and quantification for phenols, using the sensory materials $\mathbf{F}_{005} \mathbf{B}$ and $F_{025} \mathbf{B}$, calculated using $U V$-vis analysis and the blue parameter $(B)$ of the digital definition of the color of the films.

\begin{tabular}{cccccc} 
Phenol code & Phenol derivate & \multicolumn{2}{c}{ UV-vis analysis } & \multicolumn{2}{c}{ RGB analysis } \\
& LOD & LOQ & LOD & LOQ \\
\hline A & m-cresol & $135 \mathrm{ppb}$ & $408 \mathrm{ppb}$ & $27 \mathrm{ppb}$ & $82 \mathrm{ppb}$ \\
$\mathrm{B}$ & 2-chlorophenol & $366 \mathrm{ppb}$ & $1.1 \mathrm{ppm}$ & $123 \mathrm{ppb}$ & $373 \mathrm{ppb}$ \\
$\mathrm{C}$ & bisphenol-A & $217 \mathrm{ppb}$ & $657 \mathrm{ppb}$ & $221 \mathrm{ppb}$ & $670 \mathrm{ppb}$ \\
$\mathrm{D}$ & 4-chloro-2-methylphenol & $203 \mathrm{ppb}$ & $614 \mathrm{ppb}$ & $253 \mathrm{ppb}$ & $766 \mathrm{ppb}$ \\
$\mathrm{E}$ & 2,4-dimethylphenol & $151 \mathrm{ppb}$ & $457 \mathrm{ppb}$ & $300 \mathrm{ppb}$ & $910 \mathrm{ppb}$ \\
$\mathrm{F}$ & 2-phenylphenol & $133 \mathrm{ppb}$ & $402 \mathrm{ppb}$ & $207 \mathrm{ppb}$ & $627 \mathrm{ppb}$ \\
$\mathrm{G}$ & 1-naphthol & $121 \mathrm{ppb}$ & $369 \mathrm{ppb}$ & $181 \mathrm{ppb}$ & $547 \mathrm{ppb}$ \\
H & 2,4-dinitrophenol & $299 \mathrm{ppb}$ & $905 \mathrm{ppb}$ & $410 \mathrm{ppb}$ & $1.2 \mathrm{ppm}$ \\
I & 4-chlorophenol & $326 \mathrm{ppb}$ & $987 \mathrm{ppb}$ & $782 \mathrm{ppb}$ & $2.4 \mathrm{ppb}$ \\
J & 1,8-dihydroxyanthraquinone & $276 \mathrm{ppb}$ & $836 \mathrm{ppb}$ & $\mathrm{a} 1.8 \mathrm{ppm}$ & a5.6 ppm \\
K & 2-nitrophenol & $76 \mathrm{ppm}$ & $229 \mathrm{ppm}$ & $43 \mathrm{ppm}$ & $131 \mathrm{ppm}$ \\
$\mathrm{L}$ & fenhexamid & $193 \mathrm{ppm}$ & $584 \mathrm{ppm}$ & $49 \mathrm{ppm}$ & $150 \mathrm{ppm}$ \\
$\mathrm{M}$ & 2,4-dichlorophenol & $38 \mathrm{ppm}$ & $85 \mathrm{ppm}$ & $80 \mathrm{ppm}$ & $242 \mathrm{ppm}$
\end{tabular}

${ }^{a}$ The red component of the RGB parameters was used in this case instead of the blue due to the different color change observed in comparison with the rest of phenols. 


\subsection{Application in a real product}

After the analysis of the performance of the sensory materials for sensing phenols in water, we carried out a test with a commercial product, specifically, a fungicide based on 2-phenylphenol. In the data sheet of the product (ESI, Section S5), the manufacturer specifies that the product contains $100 \mathrm{~g}$ of 2-phenylphenol per liter $(0.5875 \mathrm{M})$. Therefore, we diluted the sample to reach a concentration of $4 \times 10^{-5}$ $M$ with aqueous $0.1 \mathrm{M} \mathrm{NaOH}$ prepared with tap water. Then, one $8 \mathrm{~mm}$ diameter disc of $F_{005} \mathbf{B}$ was dipped in $10 \mathrm{~mL}$ of this solution at room temperature for $60 \mathrm{~min}$. Then, the film was thoroughly washed with aqueous $0.1 \mathrm{M} \mathrm{NaOH}$ and photographed with a smartphone. The "B" parameter (RGB parameter) obtained from the photograph was used to calculate the concentration of 2-phenylphenol in the commercial product, DECCO ${ }^{\circledR}$ OPP 20 using the equation obtained from the titration of 2-phenylphenol (ESI, Section S6 (K)). Fig. 5 shows the result of the calculated concentration of 2-phenylphenol, which is in agreement with the concentration provided by the manufacturer.
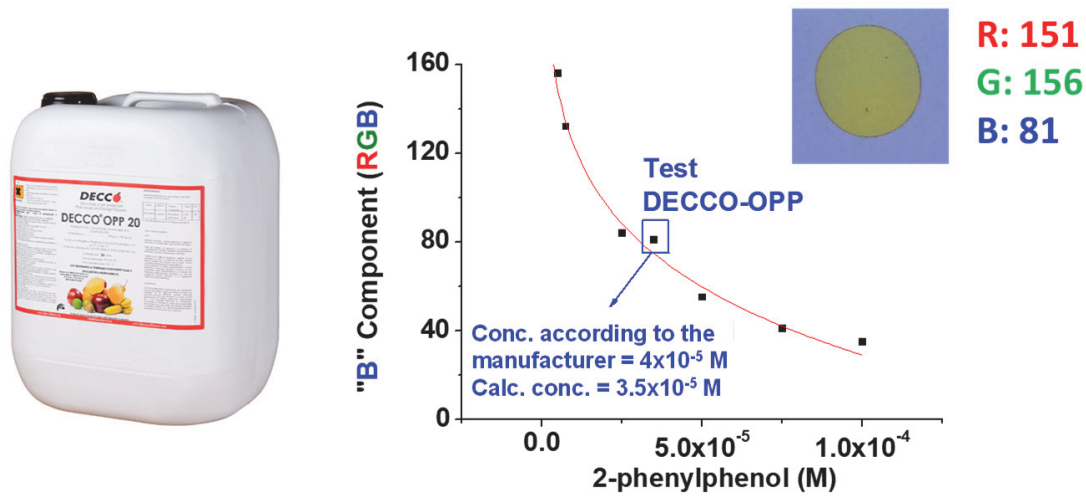

Fig. 5. Left: Image of the container of the tested commercial product. Right: titration curve using the analysis of pictures taken to the sensory discs (B parameter). The concentration of 2-phenylphenol in the commercial product was calculated using the titration curve (logarithm fitting). 


\subsection{Interference study}

ICP-MS analysis of a prepared sample of 2-phenylphenol (0.58 $\mathrm{M}$ in aqueous $0.1 \mathrm{M} \mathrm{NaOH}$ ) and the commercial product (DECCO ${ }^{\circledR} \mathrm{OPP}$ ) was carried out. The results are shown in Table 4.

As described previously, the concentration of 2-phenylphenol within the commercial product, $\mathrm{DECCO}{ }^{\circledR} \mathrm{OPP}$, was correctly calculated using the titration curve obtained from the color of the sensory films of $\mathbf{F}_{005} \mathbf{B}$ after dipping into a labmade solution of 2-phenylphenol. Thus, no interference of the different elements found in the commercial product was observed.

Table 4. ICP-MS analysis for the lab-made solution of 2-phenylphenol $(0.58 \mathrm{M}$ in aqueous $0.1 \mathrm{M} \mathrm{NaOH}$ ) and the commercial product.

\begin{tabular}{ccc} 
& Lab-made solution & Commercial product \\
\hline Si (ppb) & 25.7 & 15080.5 \\
Mn (ppb) & - & 1.8 \\
Zn (ppb) & 1.2 & 622.3 \\
Pd (ppb) & 0.2 & 49.4 \\
Ba (ppb) & 0.1 & 7.2 \\
\hline
\end{tabular}

\section{Conclusions}

We prepared polymer films with diazonium moieties pendant to the main acrylic chains. The diazonium groups within the solid materials are stable over time and can be handled without special care by untrained personnel. The materials have a gel-like behavior and, swell upon dipping in water. The colorless films react with any phenol present in the water, developing color, due to the formation of azo groups, which we have used to visually signal the presence of phenols. Additionally, we have titrated the phenols using both a conventional analytical technique, UV-vis, and an analysis of the colors of pictures taken to the sensory films with a handheld device (e.g., a smartphone); detection limits ranged from $\mathrm{ppb}$ to ppm. In short, we have used a well-known organic reaction for sensory purposes. To achieve this objective, we prepared materials with chemical groups considered inherently unstable under ambient conditions, exploiting the solidstate chemistry within macromolecular environment that usually exhibits 
completely different chemical behavior both in solution and for low molecular mass species.

\section{Acknowledgements}

The financial support provided by Fondo Europeo de Desarrollo Regional (FEDER) and the Spanish Agencia Estatal de Investigación (AEI) (MAT201784501-R) is gratefully acknowledged. We also thank the "ALBA Synchrotron", belonging to the network of "Infraestructura Científico y Técnica Singular (ICTS)", Spain, for the project $N^{\circ} 2017022034$, with the title "Structural data by infrared microspectroscopy in inorganic-organic hybrid polymer materials in the form of films with interesting optical-, antitumor-, bactericide- or sensing properties ".

\section{Appendix A. Supplementary data}

Supplementary material related to this article can be found, in the online version, at doi: https://doi.org/10.1016/i.jhazmat.2018.11.066 


\section{References}

[1] H. Swarts, F. Verhagen, J. Field, J. Wijnberg, Phytochemistry 1998, 49, 203-206.

[2] M. Pirsaheb, S. Moradi, M. Shahlaei, N. Farhadian, J. Hazard. Mater. 2018, 353, 444-453.

[3] H. Wang, M. Jing, Y. Wu, W. Chen, Y. Ran, J. Hazard. Mater. 2018, 353, 53-61.

[4] J. Gao, Y. Liu, X. Xia, L. Wang, W. Donga, J. Hazard. Mater. 2018, 353, 393-400.

[5] H. Wang, Y. Liang, L. Liu, J. Hu, W. Cui, J. Hazard. Mater. 2018, 344, 369-380.

[6] H. Zhou, G. Wang, M. Wu, W. Xu, X. Zhang, L. Liu, J. Hazard. Mater. 2018, 351, 71-79.

[7] J. Michałowicz, W. Duda, Pol. J. Environ. Stud. 2007, 16, 347-362.

[8] G. Busca, S. Berardinelli, C. Resini, L. Arrighi, J. Hazard. Mater. 2008, 160, 265-288.

[9] Toxicological Review of Phenol, EPA/635/R-02/006, U.S. Environmental Protection Agency, Washington D.C., September 2002, https://cfpub.epa.gov/ncea/iris/iris documents/ documents/toxreviews/0088tr.pdf (Accessed: January 2018).

[10] M. Saraji, M. Marzban, Anal. Bioanal. Chem. 2010, 396, 2685-2693.

[11] T. Heberer, H.-J. Stan, Anal. Chim. Acta 1997, 341, 21-34.

[12] N. Kolahchi, M. Braiek, G. Ebrahimipour, S.O. Ranaei-Siadat, F. Lagarde, N. Jaffrezic-Renault, J. Environ. Chem. Eng. 2018, 6, 478-484.

[13] Z. Lin, Y. Xiao, Y. Yin, W. Hu, W. Liu, H. Yang, ACS Appl. Mater. Interfaces 2014, 6, 1077510782.

[14] V.K. Gupta, H. Karimi-Maleh, R. Sadegh, Int. J. Electrochem. Sci. 2015, 10, 303-316.

[15] W. Lu, G.G. Wallace, M.D. Imisides, Electroanalysis 2002, 14, 325-332.

[16] H. Karimi-Maleh, M. Moazampour, A.A. Ensafi, S. Mallakpour, M. Hatami, Environ. Sci. Pollut. Res. 2014, 21, 5879-5888.

[17] S. Yang, J. Liang, S. Luo, C. Liu, Y. Tang, Anal. Chem. 2013, 85, 7720-7725.

[18] P.M. Reddya, S. Hsieh, C. Chang, J. Kang, J. Hazard. Mater. 2017, 334, 93-103.

[19] V.K. Gupta, N. Mergu, L.K. Kumawat, A.K. Singh, Talanta 2015, 144, 80-89.

[20] V.K. Gupta, N. Mergu, L.K. Kumawat, A.K. Singh, Sens. Actuators B: Chem. 2015, 207, 216-223.

[21] V.K. Gupta, A.K. Singh, L.K. Kumawat, Sens. Actuators B: Chem 2014, 195, 98-108.

[22] W. Lu, X. Dong, L. Qiu, Z. Yan, Z. Meng, M. Xue, X. He, X. Liu, J. Hazard. Mater. 2017, 326, 130 137.

[23] L. Hu, X. Yan, Q. Li, X. Zhang, D. Shan, J. Hazard. Mater. 2017, 329, 205-210.

[24] A. Promchat, P. Rashatasakhon, M. Sukwattanasinitt, J. Hazard. Mater. 2017, 329, 255-261.

[25] W. Smith, C.E. Waring, J. Am. Chem. Soc. 1942, 64, 469-470.

[26] D.F. DeTar, M.N. Turetzky, J. Am. Chem. Soc. 1955, 77, 1745-1750.

[27] D.F. DeTar, A.R. Ballentine, J. Am. Chem. Soc. 1956, 78, 3916-3920.

[28] D.F DeTar, M.N. Turetzky, J. Am. Chem. Soc. 1956, 78, 3925-3928.

[29] S. Vallejos, A. Muñoz, S. Ibeas, F. Serna, F.C. García, J.M. García, J. Mater. Chem. A 2013, 1, 15435-15441.

[30] S. Vallejos, J.A. Reglero, F.C. García, J.M. García, J. Mater. Chem. A 2017, 5, 13710-13716.

[31] M. Yin, Y. Ye, M. Sun, N. Kang, W. Yang, Macromol. Rapid. Commun. 2013, 34, 616-620.

[32] J.C. Colbert, R.M. Lacy, J. Am. Chem. Soc. 1946, 68, 270-271.

[33] E.S. Lewis, E.B. Miller, J. Am. Chem. Soc. 1953, 75, 429-432.

[34] J.M. García, S. Vallejos, E. Hernando, M. Trigo-López, F.C. García, M. García-Valverde, D.I. Iturbe, M.J. Cabero, R. Quesada, J. Mater. Chem. B 2018, 6, 3735-3741.

[35] S. Vallejos, A. Muñoz, F. García, F. Serna, S. Ibeas, J.M. García, J. Hazard. Mater. 2012, 227 $228,480-483$.

[36] S.E. Bustamante, B.L. Rivas, J.M. García, S. Vallejos, F. García, J. Appl. Polym. Sci. 2018, 135, 46185-46191.

[37] Y.C. Fiamegos, C.D. Stalikas, G.A. Pilidis, M.I. Karayannis, Anal. Chim. Acta 2000, 403, 315-323.

[38] Y. Jyisy, C. Ming-Liang, Analyst 2000, 126, 881-886.

[39] L. Fariña, E. Boido, F. Carrau, E. Dellacassa, J. Chromatogr. A 2007, 1157, 46-50.

[40] C. Pérez, J. Simal, P. Paseiro, S. Paz, J. Simal, Analysis 1993, 21, 367-371.

[41] A. Danhel, K. Keung Shiu, B. Yosypchuk, J. Barek, K. Peckova, V. Vyskocil, Electroanalysis 2009 $21,303-308$. 
[42] W. Markowski, L.K. Czapinska, A.J. Józefczyk, K. Glowniak, J. Liq. Chromatogr. Relat Technol. 1998, 21, 2497-2507.

[43] Q. Wang, H. Qiu, J. Li, X. Liu, S. Jiang, J. Chromatogr. A 2010, 1217, 5434-5439.

[44] Reregistration Eligibility Decision (RED) m-cresol and xylenol https://archive.epa. gov/pesticides/reregistration/web/pdf/4027.pdf (Accessed 20 March 2018).

[45] Pesticide fact sheet-Fenhexamid https://www3.epa.gov/pesticides/chem_search/ reg_actions/registration/fs_PC-090209_20-May-99.pdf (Accessed 20 March 2018).

[46] S. Tayama, N. Kamiya, Y. Nakagawa, Mutat. Res. Genet. Toxicol. Environ. Mutagen. 1989, 223, 23-33.

[47] R. Maggio, P. Damiani, A. Olivieri, Anal. Chim. Acta 2010, 677, 97-107.

[48] H. Sun, O. Shen, X. Xu, L. Song, X. Wang, Toxicology 2008, 249, 238-242.

[49] L. Sendelbach, Toxicology 1989, 57, 227-240.

[50] Guidelines for Drinking-Water Quality, WHO, Geneva, 1998.

[51] N. Fattahi, Y. Assadi, M. Hosseini, E. Jahromi, J. Chromatogr. A 2007, 1157, 23-29.

[52] G. Ahmed, R. Laíño, J. Calzón, M. García, Microchim. Acta 2014 182, 51-59.

[53] L. Vandenberg, R. Hauser, M. Marcus, N. Olea, W. Welshons, Reprod. Toxicol. 2007, 24, 139177. 

Easy and inexpensive method for the visual and electronic detection of oxidants in air by using vinylic films with embedded aniline 



\title{
Easy and inexpensive method for the visual and electronic detection of oxidants in air by using vinylic films with embedded aniline
}

Blanca S. Pascuala, Saúl Vallejos ${ }^{b,}$ José A. Reglero Ruiz ${ }^{a,{ }^{*}}$, Juan C. Bertolín ${ }^{b}$, César Represa ${ }^{b}$, Félix C. García ${ }^{a}$, José M. García ${ }^{\text {. }}$

aDepartamento de Química, Facultad de Ciencias, Universidad de Burgos, Plaza de Misael Bañuelos, s/n, 09001, Burgos, Spain.

bepartamento de Ingeniería Electromecánica. Área de Tecnología Electrónica. Escuela Politécnica Superior, Universidad de Burgos, Avda. Cantabria, s/n, 09006, Burgos, Spain.

\section{Graphical abstract}

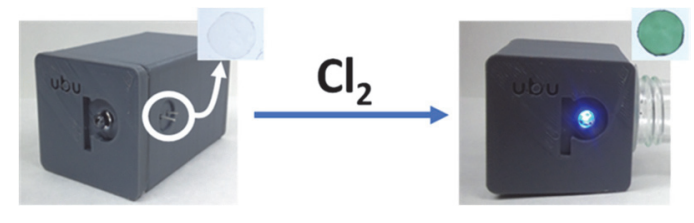

\begin{abstract}
Conventional nonconductive vinylic films with dispersed aniline change their color and become conductive in the presence of specific oxidant gases, namely, chlorine and hydrogen peroxide. The color change arises from the polymerization of the aniline to yield the conjugated polymer polyaniline, which at the same time renders the flexible vinylic films conductive. We present a simple and straightforward method using both colorimetric and electrical responses to detect and quantify the presence of oxidants $\left(\mathrm{Cl}_{2}\right.$ and $\left.\mathrm{H}_{2} \mathrm{O}_{2}\right)$ in the air. Using RGB analysis (red, green and blue parameters defining the colors in digital pictures on a computer display) based on different pictures taken with a smartphone of discs extracted from the films and by measuring the UV-vis spectral variation in the presence of different concentrations of $\mathrm{Cl}_{2}$ and $\mathrm{H}_{2} \mathrm{O}_{2}$, we obtained limits of detection and quantification between 15 and 200 ppb for $\mathrm{H}_{2} \mathrm{O}_{2}$ and between 37 and $583 \mathrm{ppb}_{\mathrm{v}}$ for $\mathrm{Cl}_{2}$. Additionally, the electrical response was measured using a fabricated device to visually detect the electrical conductivity activation of the sensor in the presence of oxidant atmospheres, detecting a rapid decrease in resistivity (three orders of magnitude) when the polymerization of aniline began, changing the film from non-conductive to conductive.
\end{abstract}




\section{Introduction}

We present herein the straightforward and inexpensive detection of oxidant agents, such as hydrogen peroxide $\left(\mathrm{H}_{2} \mathrm{O}_{2}\right)$ and chlorine $\left(\mathrm{Cl}_{2}\right)$, in air. The detection of these compounds is useful from a civil security and military point of view; chlorine has been used as a chemical warfare agent (CWA) since World War I [1], and hydrogen peroxide has been used to prepare homemade explosives, such as triacetone triperoxide (TATP), recently used in terrorist attacks in Europe [2].

Many authors have described the detection of these oxidants by exploiting polymers, including polyaniline (PANI), as piezoelectric, chemomechanical, electrochemical, colorimetric and fluorescence sensors [3-11]. Regarding PANI, numerous works are found in the literature employing nanocomposite materials based on PANI to detect different oxidant atmospheres. PANI-MnO ${ }_{2}$ nanofibers were used to electrochemically determine $\left[\mathrm{H}_{2} \mathrm{O}_{2}\right]$, with limit of detection (LOD) values of $0.1 \mathrm{mM}$ [12]. Core-shell polycaprolactone-PANI fibers were employed to detect ammonia gas, with a LOD of $1 \mathrm{ppm}$ [13]. Additionally, silver-PANI nanocomposites (such as nanorods) were used to detect $\left[\mathrm{H}_{2} \mathrm{O}_{2}\right]$ with LODs of 0.13-1.12 $\mu \mathrm{M}$ [14]. Different PANI nanoparticles with reduced graphene oxide (RGO) have been used as sensors for ammonia, with a LOD of approximately 50 ppm [15]. In addition, the review presented by Fratoddi et al. describes the use of different nanofibers based on PANI as chemoresistance sensors to detect different gases with a LOD of $20 \mathrm{ppm}$ [16]. PANI has also been used in thin films to detect alcohol vapors using quartz crystal microbalances [17] and in titanium (IV) phosphate nanocomposites to detect ammonia vapors [18]. Other recent works presented by several authors have analyzed the detection of humidity using organic/inorganic polyaniline-based nanocomposites $[19,20]$, the quantification of 4-nitrophenol using Ag nanowire/PANI nanocomposites with a LOD of $0.6 \mu \mathrm{M}$ [21], and biological applications, such as the immobilization of alpha-fetoprotein by electrochemical biosensing using microporous PANI, with a 
LOD of $3.7 \mathrm{fg} \mathrm{mL}^{-1}$ [22]. All these works dealt with sensory materials and nanomaterials using previously prepared, purified and isolated PANI.

Additionally, different works have analyzed the polymerization of aniline in the presence of oxidant atmospheres, as in the classical work of Sun et al. [23] or the recent work of Sapurina et al. [24]. However, the novelty of our research lies not specifically in the chemical polymerization of aniline, but in the use of vinylic films in which the aniline can be easily embedded and in the subsequent employment of these films as cheap and straightforward sensory materials to detect and quantify the presence of different oxidant atmospheres in the air. It is known that different pollutants can be tested in this detection process $\left(\mathrm{SO}_{2}, \mathrm{O}_{2}, \mathrm{~F}_{2}, \mathrm{Br}_{2}, \mathrm{I}_{2}\right.$, $\mathrm{H}_{2} \mathrm{O}_{2}, \mathrm{Cl}_{2}$ or $\left.\mathrm{O}_{3}\right)$. However, we focused our analysis on two different oxidants $\left(\mathrm{Cl}_{2}\right.$ and $\mathrm{H}_{2} \mathrm{O}_{2}$ ) that are reported to effectively produce the oxidation of aniline and the formation of the conductive form of PANI [25]. Then, we proposed the dispersion of aniline within a colorless, flexible and electrically isolating vinylic film that turns the material into a highly colored and conductive film comprised of a vinylic matrix containing PANI sequences. Color change was detected visually and quantified using pictures taken with a smartphone, following a similar procedure to that exposed in other previous works, in which the luminescence variation in digital pictures of different paper sensors for pesticides was analyzed by means of RGB determination using a smartphone [26], or for example the RGB analysis of different contaminants in food-safety inspection [27]. We also included the analysis of color variation using a UV-vis spectrometer. Finally, we employed a third detection technique based on the electrical resistivity variation, which can indicate within seconds the presence of oxidants (through an electrical output measured in situ and by means of a visual signal by closing an electrical circuit that turns on an LED when aniline becomes conductive due to the oxidation). Compared to the literature and specially the detection methods based on aniline nanocomposites, our measurement methodology and material preparation are easier and inexpensive, which simplifies the fabrication methods and leads to easy-to-handle films, assuring an optimal dispersion of the aniline in the sensory device and avoiding, for example, the typical agglomeration problems associated 
with nanocomposite-based materials. Additionally, these films are stable with time and can be used by unskilled personnel to inexpensively detect oxidant atmospheres within seconds at the ppb level. Finally, our work presents a novel mechanism of the detection of oxidants in phase gas, based on the in situ solidstate polymerization of aniline, which gives rise, for example, to colorimetric changes that can be detected by the naked eye.

\section{Experimental}

\subsection{Materials}

All materials and solvents were commercially available and used as received unless otherwise indicated. The following materials and solvents were used: 1vinyl-2-pyrrolidone (VP) (Merck, > 98\%), methyl methacrylate (MMA) (Aldrich, 99\%), 2-hydroxyethyl acrylate (A2HE) (Alfa Aesar, 97\%), methacrylic anhydride (AM) (Alfa Aesar, 94\%), 2,2-dimethoxy-2-phenylacetophenone (PI) (Aldrich, 99\%), sulfuric acid (AnalaR Normapur VWR, 95\%), hydrogen peroxide (VWR Prolabo Chemicals, 33\%), aniline (Sigma-Aldrich, 99\%) distilled under reduced pressure, and commercial bleach (Auchan, sodium hypochlorite $<5 \%$ ). Aqueous solutions were prepared using ultrapure water (resistivity of $18.2 \mathrm{M} \Omega \mathrm{cm}$, Milli-Q Direct 8, Millipore).

\subsection{Measurements and instrumentation}

Pictures of sensory discs (F1a) were taken with an iPhone 5 S digital camera. The RGB parameters for each disc were obtained directly after taking the pictures with the smartphone using the app called ColorMeter, which automatically averaged the data in a region of $11 \times 11$ (121) pixels. A 3D printed light box was used to collect the photos. The homemade 3D-printed (material: polylactic acid) light box $(10.7 \mathrm{~cm} \times 17.3 \mathrm{~cm} \times 12.9 \mathrm{~cm})$ used a LED display as the source of light, providing a very constant and reproducible light and obtaining high-quality photos. UV-vis measurements were carried out in a Diode Array Spectrophotometer 8452, Hewlett Packard. The RGB calculation parameter software itself carried out an average determination of the red, green and blue 
values in a region of the disc; thus, we directly used the values provided by the image analysis software. The experimental error associated with the UV-vis spectrophotometer measurements was approximately $0.1 \%$, corresponding to the precision of the equipment.

The visual alarm system was based on a new 3D-printed light emitting sensory system (material: polylactic acid, dimensions: $6.3 \mathrm{~cm} \times 4 \mathrm{~cm} \times 4 \mathrm{~cm}$ ), which allowed the detection of the in situ formation of the conductive form of PANI, green emeraldine salt (ES), by activating the blue LED incorporated in the system. Finally, the electrical conductivity measurements were carried out using a four-probe sensor $\left(\mathrm{JANDEL}^{\circledR}\right)$ and an inductive coil integrated in an electronic board (LDC1101 and MPS430) (see description in the Electronic Supplementary Information, ESI, section S1.3).

\subsection{Film preparation}

The sensory materials were vinylic films [28-30] charged with aniline species. The cross-linked films were prepared by photoinitiated bulk radical polymerization in a silanized glass mold (115 $\mu \mathrm{m}$ thick) in an oxygen-free atmosphere. The fabrication procedure and the setup employed can be found in our previous work [30]. Our method presents several advantages with respect to other film fabrication procedures, such as bubble electrospinning [31]. For example, we can produce large films $\left(20 \times 20 \mathrm{~cm}^{2}\right)$ of a controlled thickness $(10-200 \mu \mathrm{m})$ in a simple polymerization method using a UV lamp or a furnace. To fabricate the films, a solution of the comonomers was prepared, adding the PI last. To assure a homogeneous mixture, the solution was sonicated, helping to release oxygen, which could interfere with the radical PI. The solution was injected in the glass mold and exposed to UV light (250 w UV mercury lamp, Philips HPL-N, emission bands in the UV region at $304,314,335$, and $366 \mathrm{~nm}$ with the maximum emission at $366 \mathrm{~nm}$ ) for $2 \mathrm{~h}$.

For the preparation of the film F1, the following comonomers were employed: VP and $\mathrm{MMA}$ in a comonomer ratio of $50 \% \mathrm{VP}$ and $50 \% \mathrm{MMA}$; $\mathrm{AM}$ at a mol 
percentage of 1 with respect to the overall comonomer molar content; and 0.16 wt. $\% \mathrm{PI}$ as a radical photoinitiator.

Similarly, the preparation of the second film F2 was carried out using these comonomers: $\mathrm{A} 2 \mathrm{HE}$ and $\mathrm{MMA}$ in a comonomer ratio of $50 \% \mathrm{~A} 2 \mathrm{HE}$ and $50 \%$ MMA; $\mathrm{AM}$ at a mol percentage of 1 with respect to the overall comonomer molar content; and 0.16 wt. \% of $\mathrm{PI}$ as the photoinitiator.

This monomer molar ratio and the addition of the crosslinker assured excellent handleability combined with a good swelling behavior, which is the first in this kind of sensory film.

The films were demolded, washed with running water for one hour, and dried in air. Several samples of both films $\left(100 \mathrm{~cm}^{2}\right)$ were obtained with good reproducibility, presenting easy handleability.

To achieve the sensory behavior, the films (F1 and F2) were immersed into an aqueous solution of aniline in acidic media $\left(\mathrm{H}_{2} \mathrm{SO}_{4}\right)$, to give $\mathbf{F 1 a}$ and $\mathbf{F 2 a}$. The charging process required a solution of aniline $(20 \mathrm{mmol}, 1.82 \mathrm{~mL}, 0.44 \mathrm{M})$ in ultrapure water $(45 \mathrm{~mL})$ with $95 \%$ sulfuric acid $(55.62 \mathrm{mmol}, 3.12 \mathrm{~mL}, 1.24 \mathrm{M})$. This immersion was carried out in a $250-\mathrm{mL}$ beaker. This process was carried out at room temperature within 2 hours with no stirring. After the charging process, the films were removed from the solution. The remaining drops of the solution were superficially dried with paper. During this process, the films were kept as smooth as possible to make subsequent treatment easier. The films were dried for one hour in air, and afterwards, the surfaces were carefully cleaned with a wet paper to remove the rest of the anilinium salt. Finally, the films were cut into 8 $\mathrm{mm}$ discs.

Several preliminary tests were performed for different purposes. First, the optimization of the measurement processes (RGB, representing the red, green and blue colors on a computer display, UV-vis and specially the novel setup to determine the electrical resistivity variation) was conducted. Second, we selected the comonomers, proportions and charging conditions to obtain optimized films 
in terms of wettability, handleability and flexibility. Finally, we focused our work on two different pollutants $\left(\mathrm{Cl}_{2}\right.$ and $\left.\mathrm{H}_{2} \mathrm{O}_{2}\right)$ that assured the oxidation of the aniline, in order to cause polymerization and obtain the conductive form. Concerning the repeatability of the measurements, we performed two repetitions of each measurement with discs extracted from the same F1a and F2a films, obtaining comparable results.

Fig. $1 a$ and $b$ presents the chemical structure and the photographs of the prepared films. We performed different SEM measurements on the surfaces of the films (see Fig. S12 in section S4 of the ESI). All the films presented a flat surface without any specific surface morphology, probably due to the confinement of the films between two silanized glasses during the polymerization process.

a)
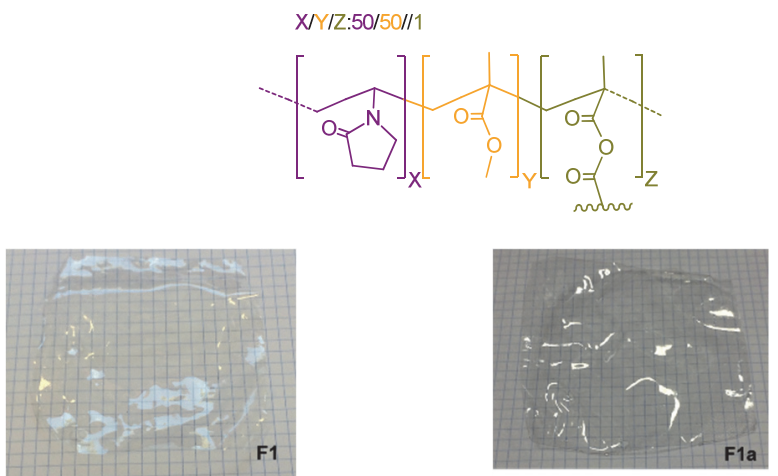

b)

X/YIZ:50/50//1
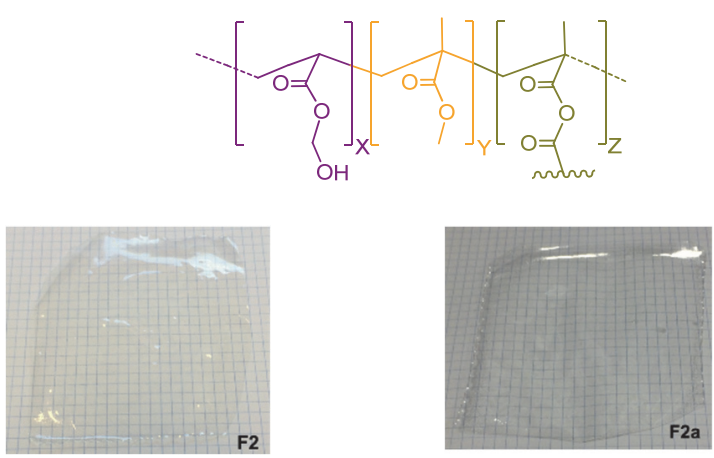

Fig. 1. Scheme of the chemical composition of: a) F1 and b) F2 with photographs of the films (F1 and F2) and sensory films (F1a and F2a). 


\section{Results and discussion}

The films showed moderate hydrophilic character (water swelling percentage of $47 \%$ for $\mathbf{F} 1$ and $27 \%$ for F2), which allows the films to be charged with the acidic species of aniline after immersion for $2 \mathrm{~h}$ in $45 \mathrm{~mL}$ of water containing $1.82 \mathrm{~mL}$ of aniline and $1.56 \mathrm{~mL}$ of sulfuric acid, thus transforming the films into the oxidant-sensory materials (F1a and F2a, respectively). The swelling behavior was determined following a simple previously described procedure [30].

The measurements of F1a with the 4-probe sensor were not reproducible because of the bad contact between the film and the metallic tips. F2a was synthesized to overcome this problem, as F2a was more flexible than F1a and the tips could slightly penetrate the film, assuring good electrical contact. Then, F1a was used in all the experiments in which colorimetric and UV-vis detection and LED sensors were employed, and F2a was employed in the detection process with the four-point probe/inductive sensor, due to its flexibility.

\subsection{RGB analysis}

F1a responded to oxidant substances in the gaseous and vapor states by developing a deep color, thus allowing the detection of harmful atmospheres. Oxidant atmospheres containing $\mathrm{Cl}_{2}$ and $\mathrm{H}_{2} \mathrm{O}_{2}$ gas were created using different amounts of aqueous solutions of commercial $\mathrm{H}_{2} \mathrm{O}_{2}$ ( $33 \%$ aq.) and commercial bleach (5\% in $\mathrm{NaClO}$ aq.) for chlorine. It is important to remark that the gas concentration of $\mathrm{Cl}_{2}$ and $\mathrm{H}_{2} \mathrm{O}_{2}$ inside the vial was estimated from the liquid concentration of the prepared solutions through the volume of the vial, obtaining the estimated values listed in Table $\mathrm{S} 1$ of the ESI. Then, in the case of $\mathrm{H}_{2} \mathrm{O}_{2}$, it can be easily assumed that all of the initial liquid pollutant concentration transformed to the gas phase. For the $\mathrm{Cl}_{2}$ atmosphere, the drying of the bleach inside the vials renders principally $\mathrm{NaClO}$ at different hydration levels, which decomposes mainly to $\mathrm{Cl}_{2}$ and $\mathrm{O}_{2}$, catalyzed by the carbon dioxide present in the air, and 
probably also to other species. Thus, in this study, the concentration of $\mathrm{Cl}_{2}$ in the vials used for the tests was calculated assuming that all the $\mathrm{NaClO}$ decomposes to $\mathrm{Cl}_{2}$, and for the abovementioned reason, this value is an approximation. Detailed information on the preparation of the oxidant atmospheres can be found in the ESI, Section S1.1. We performed the preliminary interference tests using $\mathrm{CO}_{2}, \mathrm{O}_{2}, \mathrm{~N}_{2}, \mathrm{O}_{3}, \mathrm{SO}_{2}$ and $\mathrm{NO}_{\times}$gases, observing that the detection results of $\mathrm{H}_{2} \mathrm{O}_{2}$ and $\mathrm{Cl}_{2}$ were not affected by the presence of these gases (see Table S4 in section S5 of the ESI, showing the color developed by the discs in the presence of different oxidants).

The color developed by the colorless F1a depends on the oxidant. Both oxidants, $\mathrm{Cl}_{2}$ and $\mathrm{H}_{2} \mathrm{O}_{2}$, induced the polymerization of aniline to give PANI; in the case of hydrogen peroxide, the resulting PANI was brown due to the formation of electrically isolating oligomers. On the other hand, with chlorine, the PANI formed corresponds to the green conductive emeraldine salt as it can be seen clearly in the color evolution of the discs presented in Fig. $2 \mathrm{a}$ and $2 \mathrm{~b}$. To determine the presence of the PANI, we performed some preliminary FTIR experiments in the films before and after the sensing process under a $\mathrm{Cl}_{2}$ atmosphere, finding a peak variation at approximately $3000 \mathrm{~cm}^{-1}$ in the films with PANI, thus evidencing the presence of conductive emeraldine salt due to the induced polymerization process [32] (see section S3 in the ESI).
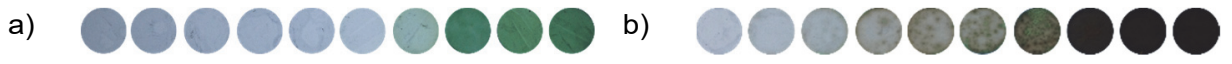

Fig. 2. Sensory response of F1a discs to: a) chlorine, [Cl $]$ : blank, 16, 39, 79, 118, $157,394,787,1180$ and 1574 ppbv; b) hydrogen peroxide, [ $\left.\mathrm{H}_{2} \mathrm{O}_{2}\right]$ : blank, 34, 87, $174,261,347,868,1737,2605$ and 3474 ppbv.

The color development in F1a was used to quantify the concentration of the oxidant in air by using two different techniques: a) RGB parameters, based on processing a picture taken with a smartphone or digital camera in a retroilluminated homemade light box (see ESI for details, section S1) and b) UV-vis spectroscopy. The analysis of the photographs taken of the 
sensory materials is a simple, inexpensive, and efficient way of measuring concentrations. We employed a commercial software to extract the RGB color model, following the procedure described in section 2.2. Afterwards, the RGB parameters can combined into one variable (PC1, principal component 1 ) by the principal analysis (PCA) procedure [33,34], allowing for the construction of simple titration curves where a relationship between PC1 and oxidant concentration can be observed (see Fig. 3a and b). To obtain a direct relation between PC1 and the oxidant concentration, we did not use the highest values of $\mathrm{Cl}_{2}$ and $\mathrm{H}_{2} \mathrm{O}_{2}$ concentrations and employed only the data below $157 \mathrm{ppb}$ and $347 \mathrm{ppb}$ for $\mathrm{Cl}_{2}$ and $\mathrm{H}_{2} \mathrm{O}_{2}$, respectively, as described in the caption of Fig. 3. Details of the PCA analysis can be found in Tables S2 and S3 in the ESI.
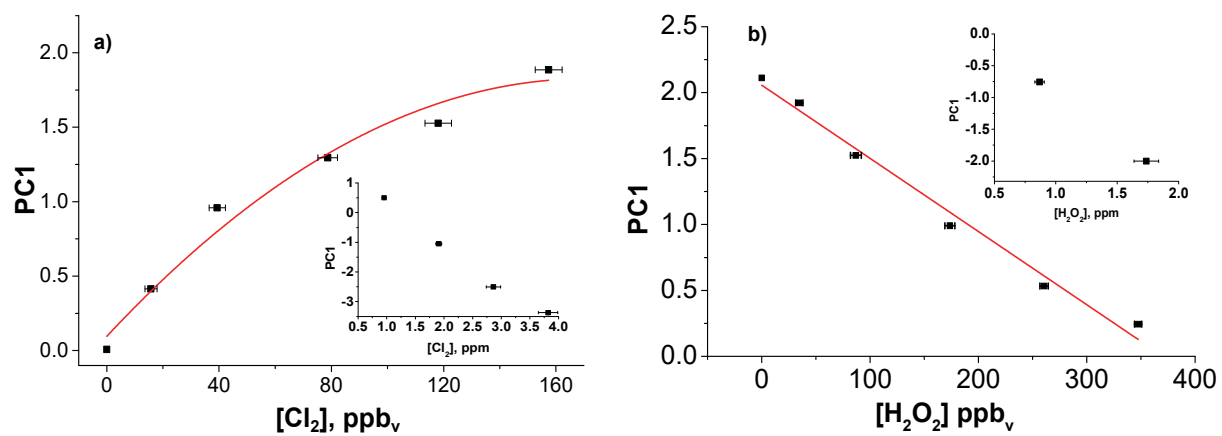

Fig. 3. Titration curves of $\mathbf{F} 1 \mathrm{a}$ discs exposed to oxidants in air: a) Chlorine, $\left[\mathrm{Cl}_{2}\right]=$ blank, $16,39,79,118$ and $157 \mathrm{ppbv}$; b) Hydrogen peroxide, $\left[\mathrm{H}_{2} \mathrm{O}_{2}\right]=$ blank, 35, 87, 174, 261 and $347 \mathrm{ppb}_{\mathrm{v}}$, using RGB parameters, reduced to one principal component (PC1) by principal component analysis; Inset: Relation between PC1 and oxidant concentration at high values.

\subsection{UV-vis analysis}

The analysis of the sensory discs of F1a upon exposure to oxidant atmospheres by UV-vis is shown in Fig. 4a-4d, from which titration curves are built. Limits of detection in the $\mathrm{ppb}_{v}$ range were obtained from the titration curves built with RGB and UV-vis data, as depicted in Table 1. Compared to the UV-vis results, which require a long data treatment time and the use of specific equipment, the simple and straightforward use of pictures taken of the F1a sensory discs is a costless and instant way of implementing an analytical technique based on everyday 
technology, e.g., smartphones. However, UV-vis analysis provides a better dynamic range.
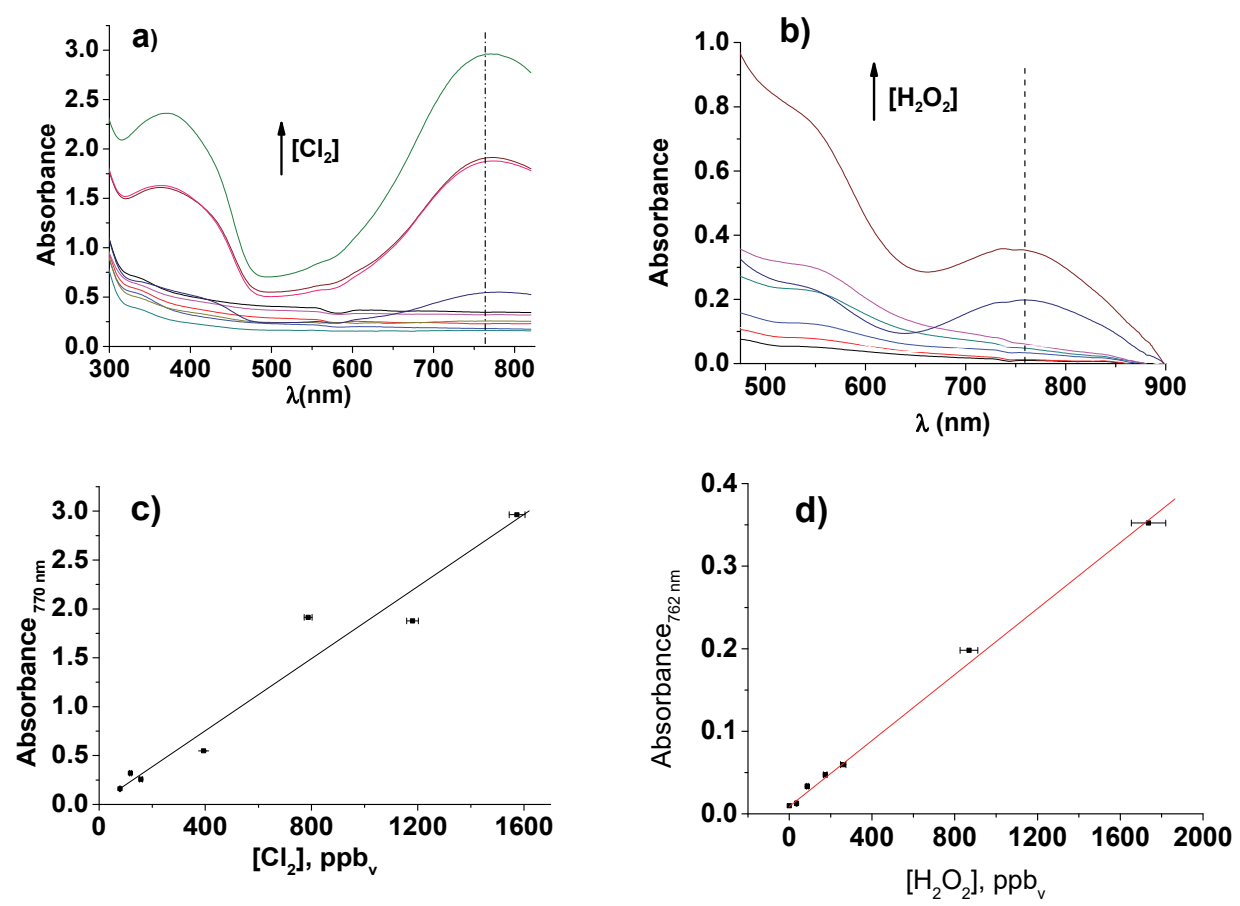

Fig. 4. UV-Vis spectra of $\mathrm{F} 1 \mathrm{a}$ discs after exposing them to increasing concentration of $\mathrm{Cl}_{2}$ (a) and $\mathrm{H}_{2} \mathrm{O}_{2}$ (b) in air; c) Titration curve for chlorine, [Cl2]: 79, 118, 157, 394, 787, 1180 and $1574 \mathrm{ppb}$; d) Titration curve for hydrogen peroxide, $\left[\mathrm{H}_{2} \mathrm{O}_{2}\right]: 0,35,87,174,261,868$ and 1737 ppbv. 


\subsection{Electrical conductivity measurements}

In the case of detection of chlorine, in addition to the change in color, the polymerization of the aniline dispersed in the films leads to the green electrically conductive form of PANI, called emeraldine salt (ES). Accordingly, the detection of $\mathrm{Cl}_{2}$ can be carried out by measuring the resistivity of the vinylic films during the formation of the ES. Then, two different detection devices were developed.

First, a visual alarm system consisting of an open electrical circuit with a LED light was developed. This circuit can be closed with a conductive material, switching on the light. This system provides a qualitative detection of chlorine in air (see ESI, Fig. S6), working as a visual alarm. Fig. 5a-C present the visual system, which can also be designed as a sound alarm.
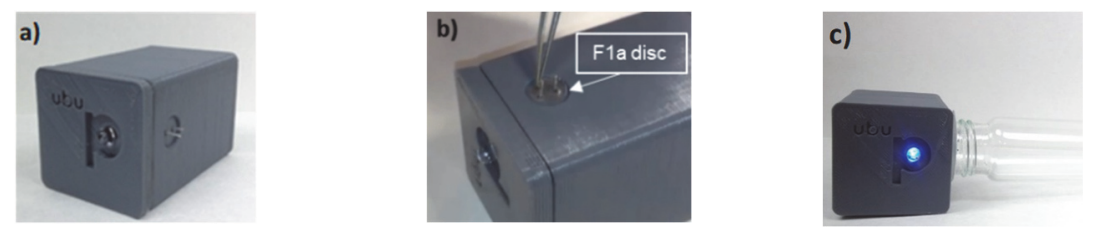

Fig. 5. Visual alarm system: a) physical appearance; b) setting of the sensory F1a disc in the metallic terminals; c) blue led switched-on due to the formation of emeraldine salt by the presence of chlorine in the environment of the sensory disc (1 ppmv) (For interpretation of the references to colour in this figure legend, the reader is referred to the web version of this article).

Second, a four-point probe/inductive sensor was used to quantitatively measure the electrical behavior of the sensory film F2a during the process of detection, showing a decrease in resistivity due to the formation of the conductive ES (see ESI, Figs. S7 to S10 in Section S1.3, for details).

Combining the data from the four-point probe sensor and the inductive sensor, it is possible to observe the evolution of resistivity, measured in Ohms per square, of the sensory film F2a in the presence of chlorine (Fig. 6).

The resistivity of the film decreases due to the formation of the conductive form of PANI, emeraldine salt (ES). Moreover, a quick resistivity drop in the material, 
up to three orders of magnitude, was observed within the first half-minute of measurement, thus pointing to the applicability of the system in the rapid detection of harmful atmospheres.

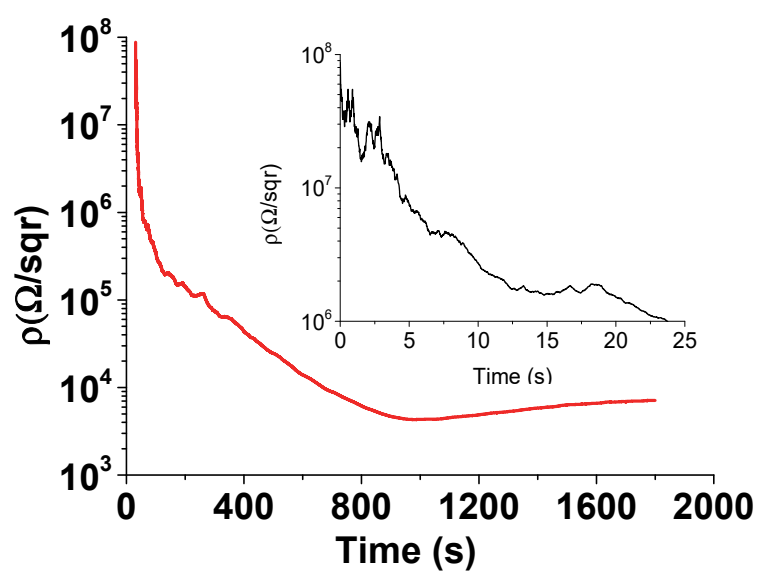

Fig. 6. Evolution of the resistivity of the sensory film F2a exposed to chlorine in air, $\left[\mathrm{Cl}_{2}\right]$ : 230 ppmv. $[\rho]=\Omega /$ sqr, units of sheet resistance; liset: resistivity drop during the initial $25 \mathrm{~s}$ of measurement. 


\section{Conclusions}

Briefly, we have developed the synthesis of simple and inexpensive vinylic films with embedded aniline for the visual and electrical detection of oxidant atmospheres (chlorine and hydrogen peroxide). The presence of oxidants in the environment of the sensory films caused a color change in the films that can be seen by the naked eye and easily quantified by analyzing pictures taken of the films. The color change is accompanied by the development of conductivity, and this property can be used to indicate the presence of oxidants using a four-point probe/inductive sensor or even an extremely simple electrical circuit with a LED light, then developing a visual alarm device in which the light turns on in the presence of oxidants. The vinylic-based films are easily prepared, and after the charging process with aniline, the films can be stored under normal conditions for several weeks before the sensing process, thus presenting an excellent shelf life. The sensory films are truly dosimeters because the sensing comes from the irreversible polymerization of the aniline, so the films cannot be reused.

\section{Funding}

The financial support provided by FEDER (Fondo Europeo de Desarrollo Regional) and the Spanish Agencia Estatal de Investigación (AEI) (MAT2017$84501-\mathrm{R})$ is gratefully acknowledged.

\section{Appendix A. Supplementary data}

Supplementary data associated with this article can be found, in the online version, at https://doi.org/10.1016/j.jhazmat.2018.10.039. 


\section{References}

[1] E. Croddy, C.P. Armendariz, J. Hart. Chemical and Biological Warfare, Ed., Springer-Verlag, New York, 2002.

[2] M. Burks, D.S. Hage, Anal. Bioanal. Chem. 2009, 395, 301-313.

[3] J.M. García, J.L. Pablos, F.C. García, F. Serna, Sensory Polymers for Detecting Explosives and Chemical Warfare Agents, en "Industrial Applications for Intelligent Polymers and Coatings", pp. 553-576, Springer-Verlag, 2016.

[4] J.M. García, F.C. García, F. Serna, J.L. de la Peña, Polym. Rev. 2011, 51, 341-390.

[5] J.P. Lock, E. Geraghty, L.C. Kagumba, K.K. Mahmud, Thin Solid Film 2009, 517, 3584-3587.

[6] A. Mills, P. Grosshans, E. Snadden, Sens. Actuators B 2009, 136, 458-463.

[7] J.C. Sánchez, W.C. Trogler, J. Mater. Chem. 2008, 18, 5134-5141.

[8] Y. Fang, D. Zhang, X. Qin, Z. Miao, S. Takahashi, J.-I. Anzai, Q. Chen, Electrochim. Acta 2012 $70,266-271$.

[9] J. Tian, H. Li, W. Lu, Y. Luo, L. Wanga, X. Sun, Analyst 2011, 136, 1806-1809.

[10] Z. Wu, S. Yang, Z. Chen, T. Zhang, T. Guo, Z. Wang, F. Liao, Electrochim. Acta 2009, 98, 104108.

[11] C. Li, J. Hu, T. Liu, S. Liu, Macromolecules 2011, 44, 429-431.

[12] J.-H. Lee, H.-G. Hong, J. Appl. Electrochem. 2015, 45,1153-1162.

[13] W. Zhou, Y. Guo, H. Zhang, Y. Su, M. Liu, B. Dong, J. Mater. Sci. 2017, 52, 6554-6566.

[14] F. Lorestani, P. Moozarm Ni, Y. Alias, N.S.A. Manan, J. Electrochem. Soc. 2015, 162, B193-B200.

[15] X. Huang, N. Hu, R. Gao, Y. Yu, Y. Wang, Z. Yang, E. Siu- Wai Kong, H. Wei, Y. Zhang, J. Matter. Chem. 2012, 22, 22488-22495.

[16] I. Fratoddi, I. Venditti, C. Cametti, M.V. Russo, Sens. Actuators B 2015, 220, 534-548.

[17] M.M. Ayad, G. El-Hefnawey, N.L. Torad, J. Hazard. Mater. 2009, 168, 85-88.

[18] A.A. Khan, U. Baig, M. Khalid, J. Hazard. Mater. 2011, 186, 2037-2042.

[19] Q. Chen, M. Nie, Y. Guo, Sens. Actuators B 2018, 254, 30-35.

[20] D. Zhang, D. Wang, P. Li, X. Zhou, X. Zong, G. Dong, Sens. Actuators B 2018, 255, 1869-1877.

[21] C. Zhang, S. Govindaraju, K. Giribabu, Y.S. Huh, K. Yun, Sens. Actuators B 2017, 252, 616-623.

[22] S. Liu, Y. Ma, M. Cui, X. Luo, Sens. Actuators B 2018, 255, 2568-2574.

[23] Z.C. Sun, Y.H. Geng, J. Li, X.B. Jing, F.S. Wang, Synth. Met. 1997, 84, 99-100.

[24] I.Y. Sapurina, J. Stejskal, Russ. J. Gen. Chem. 2012, 82, 256-275.

[25] X. Li, X. Li, Mater. Lett., 2007, 61, 2011-2014.

[26] Q. Mei, H. Jing, Y. Li, W. Yisibashaer, J. Chen, B.N. Li, Y. Chang, Biosens. Bioelectron. 2016, 75, 427-432.

[27] Z. Liu, Y. Zhang, S. Xu, H. Zhang, Y. Tan, C. Ma, R. Song, L. Jiang, C. Yi, Anal. Chim. Acta 2017, 966, 81-89.

[28] S. Vallejos, A. Muñoz, S. Ibeas, F. Serna, F.C. García, J.M. García, ACS Appl. Mater. Interfaces 2015, 7, 921-928.

[29] S. Vallejos, A. Muñoz, F.C. García, R. Colleoni, R. Biesuz, G. Alberti, J.M. García, Sens. Actuators B 2016, 233, 120-126.

[30] S. Vallejos, J.A. Reglero, F.C. García, J.M. García, J. Mater. Chem. A 2017, 5, 13710-13716.

[31] H. Dou, H. Liu, P. Wang, J.-H. He, Therm. Sci. 2013, 17, 1508-1510.

[32] J. Stejskal, M. Trchová, Polymer 2011, 61, 240-251.

[33] G. Foca, F. Masino, A. Antonelli, A. Ulrici, Anal. Chim. Acta 2011, 706, 238-245.

[34] S. Vallejos, A. Muñoz, S. Ibeas, F. Serna, F.C. García, J.M. García, J. Mater. Chem. A 2013 ,1, $15435-15441$. 


\title{
CAPÍTULO 3
}

\section{Polimeros microporosos sensores}

\begin{abstract}
Los materiales microporosos se caracterizan por poseer una estructura basada en poros o celdas de diámetro comprendido entre una y diez micras, que pueden estar abiertas, semicerradas o cerradas dependiendo del material y de cómo se han generado. Se habla de espumas cuando el interior de estos poros está relleno de gas. Su interés reside en que permiten disminuir mucho la densidad del material y aumentar propiedades específicas como el aislamiento térmico y acústico. En el campo de los quimiosensores, la característica a explotar es el aumento de la superficie específica. En este capítulo se describe la generación y caracterización de estructuras micro y nanoporosas en filmes acrílicos y poliamidas aromáticas, junto con la mejora como sensor de un filme polimérico denso estudiado previamente por el grupo de investigación a través de la microespumación.
\end{abstract}

\subsection{Introducción}

Los materiales porosos se encuentran muy extendidos en el mundo natural, como por ejemplo en el corcho o en los tejidos óseos. Por otra parte, también se ha desarrollado una gran variedad de materiales sintéticos para cubrir diversas demandas tecnológicas, como las espumas metálicas o poliméricas.

Los primeros materiales porosos poliméricos de síntesis presentaban tamaños de poro superiores a las 200 micras, lo que suponía que, en comparación con el 
material denso, incluso a bajas densidades de poro, las propiedades mecánicas empeoraban considerablemente. En la década de los años 80 del siglo pasado el MIT (Massachusetts Institute of Technology) fue capaz de preparar polímeros microporosos con tamaños de celda del orden de $1 \mu \mathrm{m}$ [1]. Esto supuso una gran mejora no solo en las propiedades mecánicas sino también un gran avance en la aplicabilidad de estos materiales. El trabajo que se presenta en esta memoria se centra en materiales microporosos cuyo diámetro de celda se encuentra entre 1 y $10 \mu \mathrm{m}$, así como materiales nanoporosos con tamaños de celda inferiores a $1 \mu \mathrm{m}$.

Los materiales porosos se pueden definir atendiendo a tres parámetros clave: el tamaño de poro, su morfología y la densidad de poros. Además, es habitual que los poros solo se formen en el interior del material dejando una piel densa en la superficie. En cuanto al tamaño, las investigaciones se encaminan a obtener tamaños de poro cada vez menores, llegando incluso a niveles nanométricos.

Atendiendo a la morfología, se pueden presentar poros cerrados, semicerrados o abiertos. Los materiales con poros cerrados suelen tener buenas propiedades aislantes, mientras que los materiales con poros abiertos presentan buena capacidad de absorción y conectividad, algo que suele ser muy útil en aplicaciones relacionadas con membranas de separación, catálisis o liberación de fármacos. Por último, la densidad de poro hace referencia al número de poros por $\mathrm{cm}^{3}$ de material, que es relevante para un gran número de aplicaciones. Las investigaciones relacionadas con estos materiales se dirigen a tener un mayor control sobre estos tres parámetros, permitiendo así obtener materiales diseñados a la carta.

Existen múltiples métodos de generación de poros, que en muchos casos involucran el uso de disolventes, como es el caso de los métodos de impresión molecular (MIPs) y coloidal, o las plantillas autoorganizadas [1]. Estos métodos dan muy buenos resultados, aunque el paso posterior de eliminación de disolventes supone una desventaja económica, energética y medioambiental. En

[1] B. Notario, J. Pinto, M.A. Rodríguez-Pérez, Prog. Mater. Sci. 2016, 78-79, 93-139. 
este trabajo se ha usado esta metodología empleando líquidos iónicos (ILs) como generadores de estructuras porosas. En contraposición, existen métodos libres de disolventes, entre los que se encuentra el espumado mediante $\mathrm{CO}_{2}$ supercrítico $\left(\mathrm{ScCO}_{2}\right)$. Esta metodología también se ha utilizado en este trabajo para generar estructuras porosas, resultando un proceso sencillo, rápido y eficiente y que además permite modular la estructura porosa final.

Siguiendo con el objetivo principal del trabajo, en este capítulo se presenta una nueva mejora de los materiales sensores poliméricos mediante la generación de estructuras microporosas. Estas estructuras se han obtenido en filmes vinílicos y poliamidas aromáticas mediante el empleo conjunto del espumado con $\mathrm{ScCO}_{2}$ e ILs.

En la última parte de este capítulo se presenta la generación de estructura microporosa mediante $\mathrm{ScCO}_{2}$ en un filme vinílico sensible a $\mathrm{Hg}$ (II), y se analiza la mejora que supone esta transformación en el rendimiento del material sensor poroso frente al sensor polimérico denso.

\subsection{Generación de estructura microporosa en matrices poliméricas}

En este apartado se describen las matrices poliméricas sobre las que se ha generado estructura microporosa, así como los procedimientos utilizados. Las matrices poliméricas que aquí se presentan son materiales empleados tradicionalmente en la fabricación de dispositivos sensores en el grupo de investigación, y sobre ellos se sustentan los trabajos publicados en los últimos años en el campo de los materiales sensores [2]. A continuación, se presentan los dos tipos de matrices que se han utilizado.

Por un lado, se ha trabajado con filmes compuestos en su mayor parte por $N$ vinilpirrolidona (VP) y metacrilato de metilo (MMA) y, en menor proporción, un agente entrecruzante de base acrílica, como es el dimetacrilato de

[2] Grupo de polímeros, http://publicationslist.org/grupodepolimeros (accessed January 2018). 
polietilenglicol. Los filmes difieren en la longitud de cadena del entrecruzante usado, estando este en todos los casos en la misma proporción molar con respecto a los otros dos comonómeros. De esta manera, se estudia el proceso de espumado con $\mathrm{ScCO}_{2}$ sobre estos materiales y el efecto que tiene el entrecruzante en cuanto a las propiedades térmicas, mecánicas y estructurales (tamaño de poro, densidad y morfología de la celda). Por tanto, el interés de esta investigación reside en sentar unas bases de conocimiento del proceso de espumado mediante $\mathrm{ScCO}_{2}$ en filmes de esta naturaleza, lo que, a posteriori, se puede aplicar a materiales sensores con composiciones similares.

Por otro lado, se ha trabajado con poliamidas aromáticas (aramidas). En este caso, la generación de la estructura microporosa se ha abordado mediante dos procedimientos distintos. En primer lugar, se llevó a cabo el espumado con $\mathrm{ScCO}_{2}$ empleando ILs como promotores del espumado. En segundo lugar, se generó la estructura microporosa empleando únicamente ILs.

Las aramidas son polímeros que se caracterizan por su alta resistencia térmica y mecánica, lo que las convierte en materiales de altas prestaciones. Es por ello que se utilizan en aplicaciones en la industria aeronáutica y de automoción, así como en la fabricación de ropa de protección (chalecos antibalas, ropa ignífuga o guantes anticorte). Químicamente, estos polímeros presentan el enlace tipo amida unido a dos anillos aromáticos. Esta unión proporciona una gran rigidez al sistema y, a su vez, permite la formación de puentes de hidrógeno altamente direccionales, lo que contribuye a que estos materiales presenten una elevada energía cohesiva y tendencia a la cristalización. Estas características, que los convierten en materiales avanzados, también son responsables de la escasa solubilidad de los mismos en muchos disolventes comunes, así como la imposibilidad de espumar estos materiales mediante $\mathrm{ScCO}_{2}$ en condiciones convencionales. Las dos aramidas con las que se ha trabajado son la poli $(m-$ fenilen isoftalamida, MPIA) y la MPIA sustituida con un grupo azida lateral.

A continuación, se describen los métodos empleados para generar la estructura microporosa en los distintos filmes de aramidas y de polímeros vinílicos. 
En los filmes vinílicos se utilizó el procedimiento de espumado usando $\mathrm{ScCO}_{2}$ que, como se explicó en la introducción, se puede llevar a cabo en uno o dos pasos. El proceso en dos pasos (batch process) se basa en saturar la muestra polimérica con $\mathrm{ScCO}_{2}$ a altas presiones y a temperaturas relativamente bajas. Seguidamente, se reduce bruscamente la presión hasta presión atmosférica, y de esta manera se genera una primera nucleación en el polímero que posteriormente se calienta a una temperatura mayor de la $\mathrm{Tg}$ del material, lo que provoca el crecimiento de poros. El proceso en dos pasos permite controlar mejor en el crecimiento de los poros, pero presenta una mayor complicación experimental.

El proceso en un solo paso (continuous process) es el que se ha empleado en esta memoria y, al igual que el proceso en dos pasos, se basa en saturar el material polimérico con $\mathrm{ScCO}_{2}$ durante un determinado tiempo y a una temperatura de saturación para, posteriormente, despresurizar rápidamente, originándose así la estructura microporosa (Figura 3.2). En este procedimiento no se calienta al material, lo que desde el punto de vista experimental simplifica el proceso.

El espumado se lleva a cabo en un reactor de alta presión, donde se encuentran las muestras poliméricas, en forma de cuadrados recortados de filmes de dimensiones adecuadas y se colocan entre dos placas de acero, como se muestra en la Figura 3.1. Esta constricción espacial dificulta el proceso de difusión del $\mathrm{CO}_{2}$ fuera del polímero, aumentando el tiempo de residencia del gas en los filmes tras la despresurización y eliminando los gradientes de morfología y propiedades en la dirección normal a la superficie [3].

Se optimizaron experimentalmente las condiciones de saturación, variando la presión y temperatura para las distintas muestras, hasta que se fijaron unos valores adecuados para todos los filmes vinílicos. Por último, la despresurización se llevó cabo de forma manual por apertura brusca de una válvula de mariposa.

[3] S. Siripurapu, J.M. DeSimone, S.A. Khan, R.J. Spontak, Adv. Mater. 2004, 16, 989-993. 


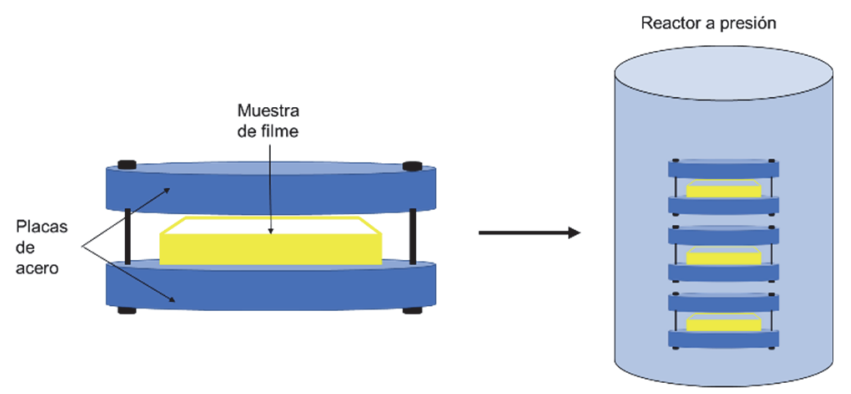

Figura 3.1. Colocación de las muestras poliméricas en forma de sándwich entre platos de acero y apilamiento dentro del reactor a presión.

La Figura 3.2 resume de forma gráfica el proceso de espumado en un paso usando $\mathrm{ScCO}_{2}$. Para una mayor claridad se han obviado las placas de acero que contienen cada muestra de filme. En la primera etapa se muestra el reactor con $\mathrm{CO}_{2}$ y el filme polimérico formando un sistema de dos fases polímero/ $\mathrm{CO}_{2}$. Cuando se aplican las condiciones de saturación correspondientes (presión y temperatura) el $\mathrm{CO}_{2}$ es capaz de disolverse en el interior del filme que se encuentra en un estado gomoso al trabajar a temperaturas próximas a su $\mathrm{Tg}$ plastificada. De esta manera se llega a una disolución supersaturada del gas en el polímero formando un sistema de una fase. En la tercera etapa, se disminuye la presión del $\mathrm{CO}_{2}$ rápidamente lo que provoca la espumación del polímero.

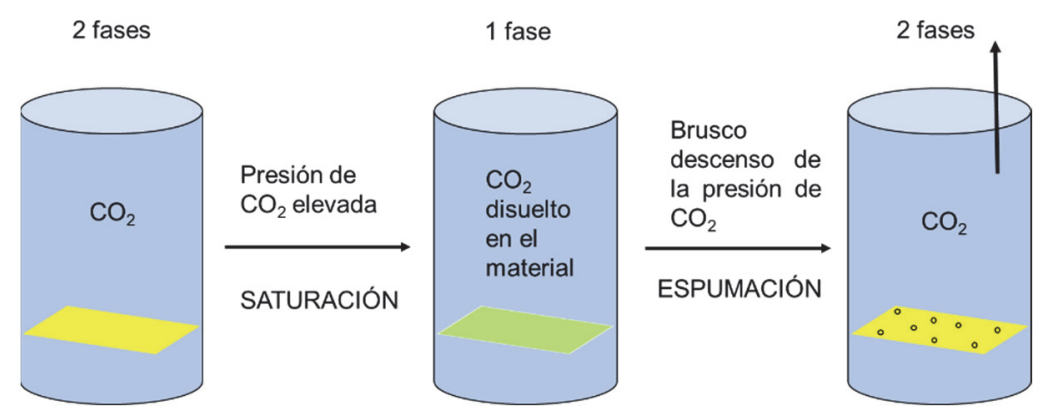

Figura 3.2. Proceso de espumado de una muestra polimérica en un paso empleando $\mathrm{ScCO}_{2}$.

Con este procedimiento de espumado se ha conseguido obtener estructuras microporosas a partir de filmes vinílicos entrecruzados de $N$-vinilpirrolidona y metacrilato de metilo. 
Para obtener aramidas con estructura microporosa se recurre en primer lugar al espumado de filmes de aramida obtenidos por disolución-evaporación (casting) a partir de disoluciones en DMA que contienen cantidades variables de IL. Como se ha comentado, las aramidas tienen propiedades excepcionales que se deben en muchos casos a su alta cristalinidad, lo que imposibilita la generación de estructuras porosas mediante $\mathrm{ScCO}_{2}$. El gas no puede penetrar en la matriz polimérica cristalina, al contrario de lo que ocurre en los polímeros amorfos. Esto hace necesario el empleo de agentes promotores de la espumación que tengan afinidad por el $\mathrm{CO}_{2}$ y faciliten su entrada en la matriz polimérica. Los ILs resultan buenos candidatos por su demostrada afinidad por el $\mathrm{CO}_{2}$ y porque pueden formar disoluciones homogéneas con las aramidas en los disolventes adecuados.

Como se comentó en la introducción, los ILs son especies compuestas por un catión de naturaleza orgánica y un anión que puede ser tanto orgánico como inorgánico. Estos compuestos también se pueden definir como sales fundidas a temperatura ambiente, o líquidos formados únicamente por iones. Sus propiedades más destacadas son su baja presión de vapor, su nula inflamabilidad, su elevada conductividad iónica, su estabilidad química y térmica, y sus altas temperaturas de fusión y descomposición. En los trabajos que aquí se describen, se utiliza el cloruro de 1-alil-3-metilimidazolinio, cuya fórmula química aparece en el Esquema 3.1.

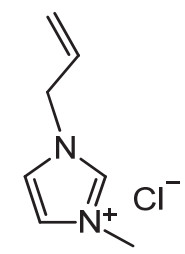

Esquema 3.1. Fórmula química del cloruro de 1-alil-3-metilimidazolinio.

El otro método utilizado para conseguir poliamidas aromáticas porosas se basa en el empleo de los ILs como agentes de generación de estructuras 
microporosas. A partir de una disolución de PA e IL en dimetilacetamida (DMA) se obtienen filmes por casting. Este proceso da lugar a un material que presenta dos fases claramente diferenciadas si se encuentra a temperatura ambiente y una única fase se si calienta a $60^{\circ} \mathrm{C}$. Este proceso es reversible y se conoce como fenómeno de separación de fases inducido térmicamente.

En un paso siguiente se sumergen estos filmes de PA/IL en agua, eliminándose así los ILs por disolución y desplazamiento por agua, que tras secarse genera la espuma (Figura 3.3b). Este hallazgo resulta muy novedoso ya que permite obtener aramidas microporosas de una forma extremadamente simple y rápida.

Para comparar las estructuras obtenidas, paralelamente se llevó a cabo el espumado con $\mathrm{ScCO}_{2}$ de los filmes de PA/IL y posteriormente se eliminan los ILs por inmersión en agua (Figura 3.3d).

a)

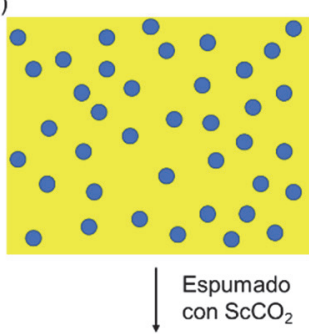

c)

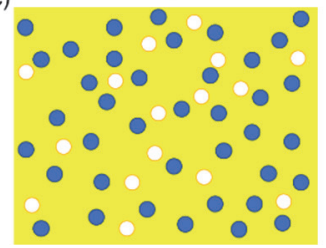

$\mathrm{H}_{2} \mathrm{O}$

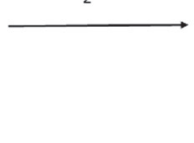

$\mathrm{H}_{2} \mathrm{O}$

b)

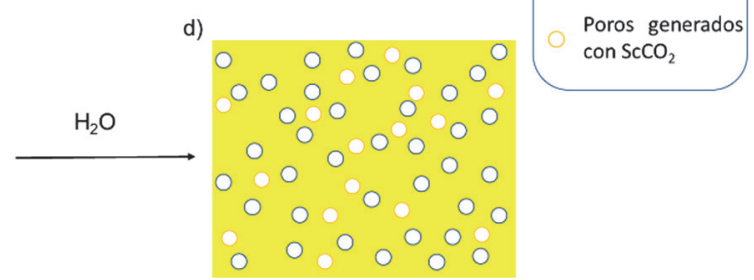

Liquido lónico

Poliamida aromática

Poros generados

al eliminar los ILs

Poros generados

con $\mathrm{ScCO}_{2}$

Figura 3.3. Proceso de estructura porosa empleando ILs y $\mathrm{ScCO}_{2}$ a) separación de fases, b) eliminación de los ILs por inmersión en agua, c) espumado con $\mathrm{ScCO}_{2}$ promovido por los ILs y d) eliminación por inmersión en agua de los ILs. 


\subsection{Comparación entre polímero sensor denso y espumado}

La aplicación de los filmes sensores porosos se ha materializado en dispositivos sensores que permitan la detección y cuantificación de analitos de interés, concretamente de mercurio en agua. Los resultados se han comparado con los publicados previamente en el grupo de investigación con filmes sensores densos [4].

Se ha elegido la estructura química de un sensor de mercurio estudiado previamente como filme sensor denso porque la detección de este catión pesado es un tema del máximo interés, dado su elevada toxicidad. Los resultados de este sensor se han comparado con los de un sensor colorimétrico en forma de filme polimérico espumado. El sensor espumado ha mejorado las características sensoras en relación con los parámetros más relevantes, es decir, tiempo de respuesta, límite de detección y límite de cuantificación.

\subsection{Resultados}

A continuación, se describen los resultados obtenidos a través de la transcripción íntegra de los cuatro trabajos publicados:

* Microcellular polymer films based on cross-linked 1-vinyl-2pyrrolidone and methyl methacrylate

* Microcellular foamed aromatic polyamides (aramids). Structure, thermal and mechanical properties

* Porous aromatic polyamides the easy and green way

* Sensory polymeric foams as a tool for improving sensing performance of sensory polymers

[4] S. Vallejos, J.A. Reglero, F.C. García, J.M. García, J. Mater. Chem. A 2017, 5, 13710-13716. 

Microcellular polymer films based on cross-linked 1-vinyl-2pyrrolidone and methyl methacrylate 



\title{
Microcellular polymer films based on cross-linked 1-vinyl-2- pyrrolidone and methyl methacrylate
}

José A. Reglero Ruiz ${ }^{a, *}$, Saúl Vallejos, Blanca S. Pascual ${ }^{a}$, Cipriano Ramos ${ }^{b}$, Sagrario Beltrán ${ }^{b}$, Félix C. García ${ }^{a}$, José M. García

${ }^{a}$ Departamento de Química, Facultad de Ciencias, Universidad de Burgos, Plaza de Misael Bañuelos s/n, 09001 Burgos, Spain.

${ }^{b}$ Departamento de Biotecnología y Ciencia de los Alimentos, Facultad de Ciencias, Universidad de Burgos, Plaza de Misael Bañuelos s/n, 09001 Burgos, Spain.

\begin{abstract}
A series of cross-linked copolymer films based on 1-vinyl-2-pyrrolidone and methyl methacrylate were produced using different poly(ethylene glycol) dimethacrylates as cross-linking agents. The average molecular mass of the cross-linking agent was varied, then allowing the foaming process using supercritical $\mathrm{CO}_{2}\left(\mathrm{ScCO}_{2}\right)$, obtaining microcellular films with different cellular structures as a function of the molecular mass of the cross-linking agent. The chemical structure, swelling behavior, $\mathrm{CO}_{2}$ uptake and cellular morphology of the materials were studied. Finally, the influence of the different cross-linking agents in the mechanical properties was also evaluated by measuring the tensile properties of the microcellular films.
\end{abstract}




\section{Introduction}

In the last two decades, supercritical carbon dioxide $\left(\mathrm{ScCO}_{2}\right)$ has been used as foaming agent to obtain microcellular polymer foams. $\mathrm{CO}_{2}$ presents numerous advantages, such as: non-toxicity, inertness, non-expensive and it can be easily employed in supercritical state in several processing applications due to the accessible critical conditions $\left(31^{\circ} \mathrm{C}\right.$ and 73 bar).

Concerning polymer foaming, $\mathrm{CO}_{2}$ presents a good solubility in amorphous polymers, and it is employed in dissolution gas foaming processes to obtain micro and nanocellular polymers [1]. The foaming process begins with the saturation of the polymer with $\mathrm{CO}_{2}$ in the supercritical regime, during a fixed time. After saturation of the sample, approaching or being in a rubbery state, system is depressurized to atmospheric pressure, taking advantage of the swelling and plasticization of the polymer, reducing the glass transition temperature, allowing the gas expansion. The cellular microstructure may be controlled by changing the saturation temperature and the depressurization rates. In the last years, the improvement of the processing techniques has led to the obtention of nanoporous polymeric materials, in which new properties have emerged due to the reduction of the cell size (i.e., below $200 \mathrm{~nm}$ ) [2]. One of the most promising and analyzed properties is the thermal conductivity, which decreases drastically when reducing the cell size, due to the apparition of the knudsen effect [3], thus obtaining lowdensity polymers with super-isolating properties [4]. In this investigation line, our group has recently published a research work focused on the thermal properties of microcellular polymer foams based on 1-vinyl-2-pyrrolidone and butyl acrylate [5]. The physical properties of nanocellular polymers has been reviewed by Notario et al.[6].

In parallel, there is an increasing interest in the development of porous polymer thin films, due to the important number of applications based on these materials. The classical techniques include the use of organic solvent in several steps reactions. However, the use of $\mathrm{ScCO}_{2}$ to generate nanoporous polymer films has attracted great attention only in the last years [7]. In this sense, different research 
works have been published reporting the fabrication of different micro or nano cellular polymeric films using $\mathrm{ScCO}_{2}$ as foaming agent $[8,9]$, but there are still several difficulties to overcome, mainly related to the rapid diffusion of the $\mathrm{CO}_{2}$ out of the polymer during the depressurization process. The research works presented by Siripurapu et al. analyze the use of different processing parameters and inorganic charges to produce microcellular polymeric films based on PMMA $[10,11]$, but only a few promising results have been reported up to date.

The confinement of the $\mathrm{CO}_{2}$ during the depressurization process is one of the key problems to obtain homogeneous micro and nanocellular polymeric films. In this sense, the use of different chemical cross-linking agents, added to the polymer matrix, can retain the $\mathrm{CO}_{2}$ molecules during the depressurization process, thus controlling the cellular structure parameters (cell density and cell size), as a function of the cross-linking agent employed $[12,13]$. In our case, the use of methacrylate-based crosslinking agents is particularly interesting due to their good $\mathrm{CO}_{2}$-philicity, thus enhancing their foamability behavior [14]. Another interesting alternative is the use of physical cross-linking process, in which the polymer is irradiated with electrons to difficult the molecular movement, stabilizing the structure during the foaming process. This research line focuses on the last published works of different authors, analyzing both the physical foaming using $\mathrm{ScCO}_{2}$ and also the use of chemical blowing agents [15-17]. On the contrary, it is well known that the use of cross-linking agents in $\mathrm{ScCO}_{2}$ foaming can difficult the $\mathrm{CO}_{2}$ sorption process, thus limiting the nucleation sites and the formation of the cellular structure.

The study of mechanical properties of foamed polymers is also a very interesting topic, especially when cell size is reduced down to micro and nanocellular range. In this sense, microcellular polymer foams offer improved toughness, strength, and stiffness respect to solid polymers. Thermal insulation in nanocellular materials has been extensively analyzed during decades, but on the other hand, the research associated to the mechanical properties of these materials has only increased recently. Following this investigation line, different authors have presented several works in the last years focused in the analysis of different 
mechanical properties (compression, tensile or impact), of micro and nanocellular amorphous polymers (mainly PMMA and PEI) obtained using $\mathrm{ScCO}_{2}$ [18-21].

Bearing all these ideas in mind, in this work we present a procedure to obtain microcellular amorphous polymeric films using $\mathrm{ScCO}_{2}$ as foaming agent with controlled morphological structure through the addition of a crosslinker agent with different molecular masses. Film is placed between two steel plates during the saturation process, then confining the $\mathrm{CO}_{2}$ during the depressurization process, allowing the formation of the microcellular structure $[9,10]$. The addition of different cross-linking agents, based on poly(ethylene glycol) dimethacrylates with different molecular masses (between 200 and 20000), tunes the cellular structure, in terms of homogeneity and cell size, and also the mechanical properties. To evaluate and quantify this correlation, the Young's modulus, elongation at break and tensile strength of the microcellular films were analyzed through low-velocity tensile tests.

\section{Experimental}

\subsection{Materials}

All materials were used as received and were commercially available. The list includes: 1-vinyl-2-pyrrolidone (VP) (Aldrich, >99\%), methyl-methacrylate (MMA) (Aldrich, $>99 \%$ ), and poly(ethylene glycol) dimethacrylate as cross-linking agent (PEGDMA) with different molecular masses (200, 750, 8000 and 20000). PEGDMA $_{200}$, PEGDMA $_{750}$ and PEGDMA 20000 were supplied by Aldrich, (>98\%), whereas PEGDMA 8000 was supplied by Alfa Aesar (>98\%). 2,2-dimethoxy-2phenylacetophenone was used as UV photo-initiator (Fotoi) (Aldrich $>99 \%$ ).

\subsection{Film preparation}

Films were prepared via a simple bulk radical copolymerization process, which is extensively described in detail in one of our previous works [22]. VP was copolymerized with MMA and the corresponding PEGDMA, with proportions 49.9925/49.9925/0.015 (molar feed ratio), using Fotoi (0.16 wt. \%) as UV radical photo-initiator. As a consequence, we maintained the nominal cross-linking ratio 
$(X)$ value fixed to $3 \cdot 10^{-4} \mathrm{~mol} P E G D M A / m o l ~ V P$ and also to $3 \cdot 10^{-4} \mathrm{~mol}$ PEGDMA/mol MMA (value of $X$ can be easily calculated as the percentage of the ratio between the moles of the cross-linker and the moles of each monomer). Then, the cross-linking density was kept constant to eliminate the influence of this parameter in the foaming behavior. Bulk radical polymerization reaction was carried out in a silanized glass mold ( $100 \mu \mathrm{m}$ thick) in an oxygen-free atmosphere at RT overnight. The chemical structure of the films is presented in Scheme 1. The films were transparent, flexible and also easily manageable.

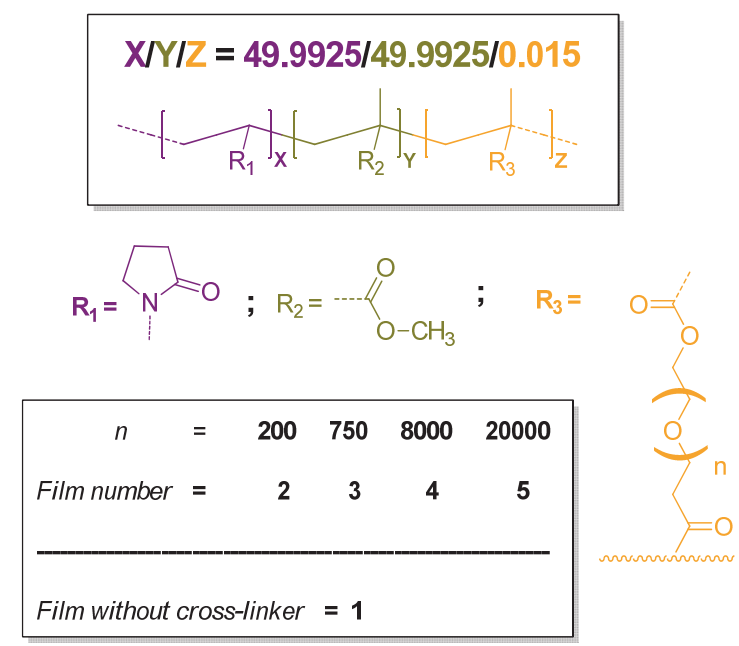

Scheme 1. Structure of the films.

\subsection{Foaming experiments}

Foaming took place in a single-step batch process using $\mathrm{ScCO}_{2}$. Films were cut in pieces of $35 \times 35 \mathrm{~mm}^{2}$ and, sandwiched between 2 steel plates of $2 \mathrm{~mm}$ thickness, to confine the gas during depressurization, thus limiting the gas diffusion process outside the material. Samples were saturated in a high-pressure reactor of $2 \mathrm{~L}$ capacity at $35 \mathrm{MPa}$ and $60{ }^{\circ} \mathrm{C}$ during $8 \mathrm{~h}$. Depressurization was carried out using a manual opening valve, with a depressurization time about $10 \mathrm{~s}$. Three different samples of each material were foamed in each batch. It is important to remark that preliminary foaming tests were performed to determine 
the optimum foaming conditions for this particular blend. Two different saturation temperatures, 30 and $40{ }^{\circ} \mathrm{C}$ were previously analyzed, keeping $35 \mathrm{MPa}$ as saturation pressure. It was found that sample 1, without cross-linker, was effectively foamed at both temperatures. However, it was necessary to increase the saturation temperature to $60^{\circ} \mathrm{C}$ to plasticize samples including the crosslinker in their formulation and obtain the foamed films. For this reason, a single batch foaming test at the previous described conditions ( $35 \mathrm{MPa}$ and $60^{\circ} \mathrm{C}$ ) was established for all the samples. Foamed films are listed as $1 f, 2 f, 3 f, 4 f$ and $5 f$.

\subsection{Physical characterization}

Characterization of the membranes was carried out using the next instrumental techniques. Infrared spectra (FT-IR) were recorded with a JASCO FT-IR 4200 (4000-400 $\mathrm{cm}^{-1}$ ) spectrometer, equipped with an ATR (Attenuated Total Reflectance) accessory. Swelling behavior was analyzed through the waterswelling percentage (WSP), defined as the weight percentage of water uptake by the membranes upon soaking until reaching equilibrium in pure water at $20{ }^{\circ} \mathrm{C}$. WSP was measured by thermogravimetric analysis (TGA), using a TGA Q50 TA Instruments equipment. Samples about $15 \mathrm{mg}$ were first dried in vacuum overnight at $40{ }^{\circ} \mathrm{C}$, and then immersed in water for $12 \mathrm{~h}$. After, TGA tests were performed, under $\mathrm{O}_{2}$ atmosphere, using the next procedure: first, samples were heated under $\mathrm{N}_{2}$ atmosphere, under a flux of $40 \mathrm{ml} / \mathrm{min}$, from RT to $100^{\circ} \mathrm{C}$ at 10 ${ }^{\circ} \mathrm{C} / \mathrm{min}$, and then kept during $30 \mathrm{~min}$ to completely eliminate the water, obtaining the swelling percentage. Then, TGA analysis was completed by heating up to $800^{\circ} \mathrm{C}$ at $10^{\circ} \mathrm{C} / \mathrm{min}$, finishing with an isotherm at $800^{\circ} \mathrm{C}$ during $10 \mathrm{~min}$ under $\mathrm{O}_{2}$ atmosphere. Test were repeated three times to minimize dispersion. To determine the tensile properties of the polymer films, strips of $5 \mathrm{~mm}$ in width and $35 \mathrm{~mm}$ in length were cut from each polymer film. Tensile tests were carried out on a SHIMADZU EZ Test Compact Table-Top Universal Tester at $20{ }^{\circ} \mathrm{C}$. Mechanical clamps were used and an extension rate of $5 \mathrm{~mm} / \mathrm{min}$ was applied using a gauge length of $9.44 \mathrm{~mm}$. At least 5 samples were tested for each polymer, and the data was then averaged. 


\subsection{Cellular morphology}

Cellular structural determination of the microcellular films was carried out in a scanning electron microscopy model JEOL JSM-6460LV. Samples were frozen in liquid nitrogen, fractured and gold coated in vacuum to assure the electrical conductivity of the samples. Cellular structural characterization was carried out throughout the determination of the average bubble radius, that was measured using the Image $J^{\circledR}$ software from SEM images [23]. The Image $J^{\circledR}$ software accounts for the number of bubbles in each image and the average radius. The number average radius $\bar{R}$ is calculated from Eq. (1):

$$
\bar{R}=\frac{\sum_{i=1}^{N} n_{i} R_{i}}{\sum_{i=1}^{N} n_{i}}
$$

where $N$ represents the bubble count. For calculation purposes, at least five different SEM images were analyzed from each material, and the results were averaged. The estimation of the cell density $N_{v}$ was calculated using the Kumar's approximation, according to Eq. (2) [24]:

$$
N_{V}=\left(\frac{n}{A}\right)^{3 / 2}
$$

where $n$ is the number of cells in the image and $A$ is the area of the image.

\section{Results and discussion}

\subsection{Solid films}

Different solid films were obtained with good surface aspect and homogeneity. Table 1 lists the formulations and the films produced. Five formulations were used, four of them containing the different cross-linking agents (films 2-5) and one of them without cross-linker (film 1). Films were transparent, flexible and also easily manageable. However, flexibility was decreased when a cross-linking agent of short chain ( $M n$ between 200 and 750) was added to the initial formulation. Each film was cut into three square samples of $35 \times 35 \mathrm{~mm}^{2}$ for foaming experiments. Samples were dried in vacuum at $40^{\circ} \mathrm{C}$ overnight before measuring their weight. Mass indicated in Table 1 corresponds to the average 
value from three square samples, which varied slightly from 0.153 to $0.160 \mathrm{~g}$, indicating the homogeneity of the films fabricated.

Table 1. Formulations employed in this work and films fabricated.

\begin{tabular}{c|ccc}
\hline Film number & $\begin{array}{c}\text { Formulation } \\
\text { (VP/MMA/PEGDMA) }\end{array}$ & Cross-linker & Mass $^{\text {solid a }}(\mathbf{g})$ \\
\hline 1 & $50 / 50 / 0$ & Not added & 0.1577 \\
2 & $49.9925 / 49.9925 / 0.015$ & PEGDMA $_{200}$ & 0.1598 \\
4 & $49.9925 / 49.9925 / 0.015$ & PEGDMA $_{750}$ & 0.1602 \\
5 & $49.9925 / 49.9925 / 0.015$ & PEGDMA $_{8000}$ & 0.1534 \\
& $49.9925 / 49.9925 / 0.015$ & PEGDMA $_{20000}$ & 0.1563
\end{tabular}

a Indicates the average mass of the three cut samples of $35 \times 35 \mathrm{~mm}^{2}$

In Fig. 1 we present a photograph of the solid sample extracted from film 2, together with a SEM micrograph of the film 3 , in which the homogeneity of the surface can be seen. The sample surface did not present any cracks or areas with rugosity. Different SEM pictures were captured in different regions of the sample, evidencing a smooth surface.
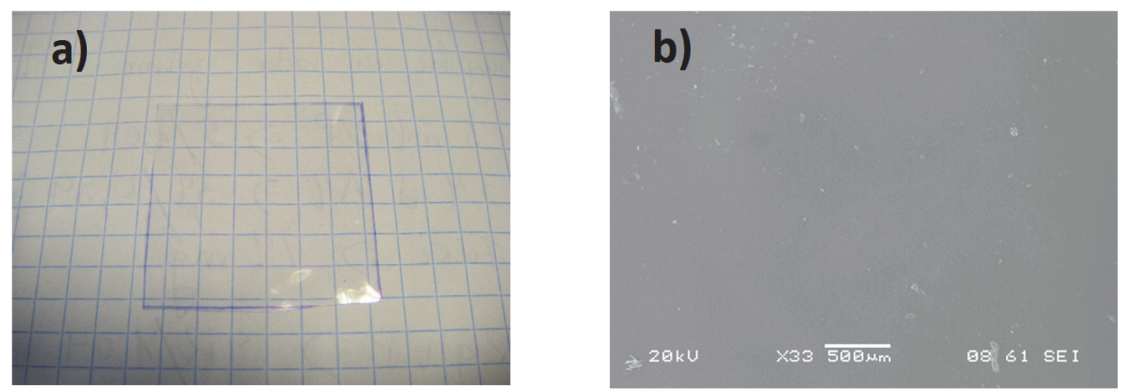

Fig. 1. Fabricated solid films: a) photograph of the sample extracted from film 2; b) SEM micrograph of the surface of film 3 (bar scale $500 \mu \mathrm{m}$ ). 


\subsection{Microcellular films}

After polymerization process, samples extracted for the films were dried in vacuum at $40{ }^{\circ} \mathrm{C}$ overnight and placed in the high-pressure reactor to carry out the $\mathrm{ScCO}_{2}$ foaming process. In Table 2 we indicate the swelling percentage of $\mathrm{CO}_{2}$ in each film, calculated from Eq. (3) by measuring the mass of the samples just after the foaming process:

$$
\% \text { wt. } \mathrm{CO}_{2}=\frac{m^{\text {foam }}-m^{\text {solid }}}{m^{\text {solid }}} \cdot 100
$$

where $m^{\text {foam }}$ and $m^{\text {solid }}$ indicate the average mass of the samples after and before the foaming process. Values of $m^{\text {solid }}$ were taken directly from Table 1, whereas $m^{\text {foam }}$ corresponds to the average mass of the foamed samples just after the foaming process. In addition, in Table 2 the value $m^{\text {final }}$ shows the mass of the foamed samples when the desorption process of $\mathrm{CO}_{2}$ is completed. In our case, this value was measured one week after the foaming process, and also after a drying process at $40^{\circ} \mathrm{C}$ in vacuum overnight, to assure that no remaining $\mathrm{CO}_{2}$ and traces of humidity were present in the samples. It is important to remark that the swelling process must be measured not after depressurization, but at the end of the saturation process. These measurements are carried out using a highpressure magnetic balance placed in the reactor [25]. In our case, measurements of swelling behavior can be only considered as an approximation, which does not take into account the $\mathrm{CO}_{2}$ loss during depressurization.

Table 2. Physical characteristics of the foamed films

\begin{tabular}{c|ccc|}
\hline Film number & Mass $^{\text {foam } \boldsymbol{a}} \mathbf{( g )}$ & $\boldsymbol{C O}_{\mathbf{2}}$ uptake $^{\boldsymbol{b}}(\%$ wt.) & Mass $^{\text {final } \boldsymbol{c}} \mathbf{( g )}$ \\
\hline 1f & 0.1770 & 12.3 & 0.1596 \\
2f & 0.1687 & 5.6 & 0.1608 \\
3f & 0.1726 & 7.8 & 0.1615 \\
4f & 0.1682 & 9.7 & 0.1549 \\
5f & 0.1739 & 11.3 & 0.1593
\end{tabular}

${ }^{a}$ Indicates the average mass of the three samples measured just after the foaming experiment.

${ }^{b}$ Indicates the average percentage of mass uptake of $\mathrm{CO}_{2}$ just after the foaming experiment.

${ }^{c}$ Indicates the average mass of the three samples measured one week after the foaming experiment. 
As it is noticed in Table 2, there is a great influence of the molecular mass of the cross-linking agent in the swelling of $\mathrm{CO}_{2}$. Swelling value is reduced from $12.3 \%$ (in samples with no cross-linking agent), to $5.6 \%$ (in samples with PEGDMA 200 ). Literature reports values of $\mathrm{CO}_{2}$ swelling percentage in methacrylate-based copolymers between 15 and $25 \%$ [26], which shows that reducing the chain length of the cross-linking agent increases the rigidity of the network, thus decreasing the quantity of $\mathrm{CO}_{2}$ absorbed, and consequently, the $\mathrm{CO}_{2}$ swelling percentage. In the case of PEGDMA 20000 (sample 6), the swelling percentage is only slightly lower than the swelling percentage of sample 1 , with no cross-linking agent added (11.3 and $12.3 \%$, respectively).

It is important to remark that although the addition of the cross-linker implies the presence of polar groups with a $\mathrm{CO}_{2}$ affinity of the ethylene-glycol not negligible (swelling percentage about $5 \%$ at $14 \mathrm{MPa}$ [27]), it is clear that the increased network rigidity associated to the cross-linking effect plays a predominant role in the reduction of the $\mathrm{CO}_{2}$ swelling percentage.

The $\mathrm{CO}_{2}$ desorption process was estimated by measuring the mass of the foamed samples at different times after the foaming process. First, measurements were performed each 5 min during two hours. Then, frequency of the measurements was reduced to 30 min during three hours, and after this time, one measurement was carried out each hour during seven hours. After this time, one measurement was carried out each twelve hours up to seven days.

Fig. 2 shows the $\mathrm{CO}_{2}$ desorption process, in which it can be seen that the equilibrium is reached about three hours after the foaming process, with a remarkable mass decrease observed during the first ten minutes. In this case, no great influence of the molecular mass of the cross-linking agent can be detected. 


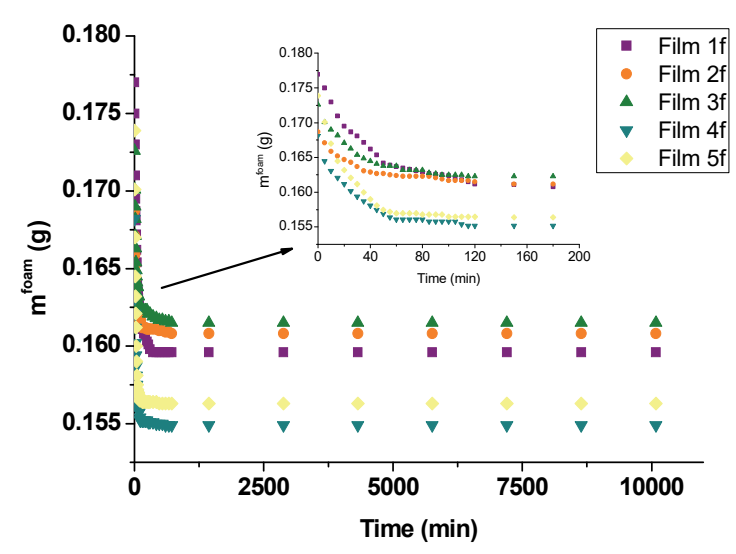

Fig. 2. Experimental curve showing the desorption of $\mathrm{CO}_{2}$ after the foaming process.

Fig. 3 presents some photographs of the five foamed samples. It is clear that increasing the molecular mass of the cross-linking agent allows for the foaming of the solid sample. Sample with no cross-linking agent (Fig. 3a, sample 1f) presents a clear opacity, and also an homogeneous white color. This is a partial indicator of the good foaming behavior of the films, because when a cellular structure is formed, transparency decays due to the diffraction of the light inside the cells, then conferring them a certain degree of opacity. This is valid only for microcellular polymer foams, with cell sizes above 50-100 nm [28].

On the contrary, the addition of the cross-linking agent of short chain length PEGDMA750 (Fig. 3c, sample 3f), makes more difficult the foaming process, showing only isolated regions in which the $\mathrm{CO}_{2}$ sorption is produced, thus conferring low foamability. Finally, sample $5 f$ (Fig. 3e), with a cross-linking agent of long chain length, PEGDMA 20000 , presents a good foaming behavior, very similar to the behavior observed in sample $1 \mathrm{f}$, in which no cross-linking agent is added. 

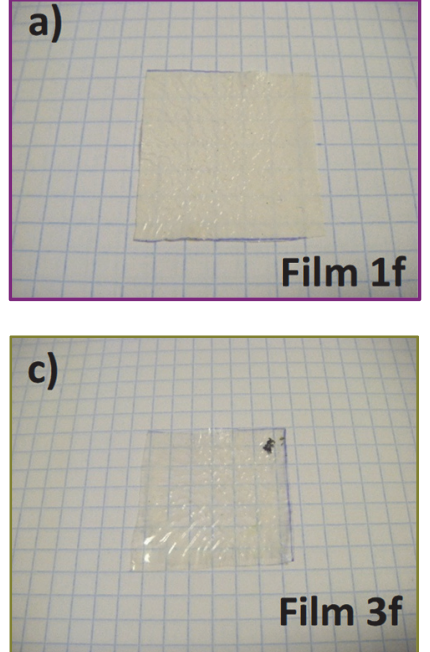
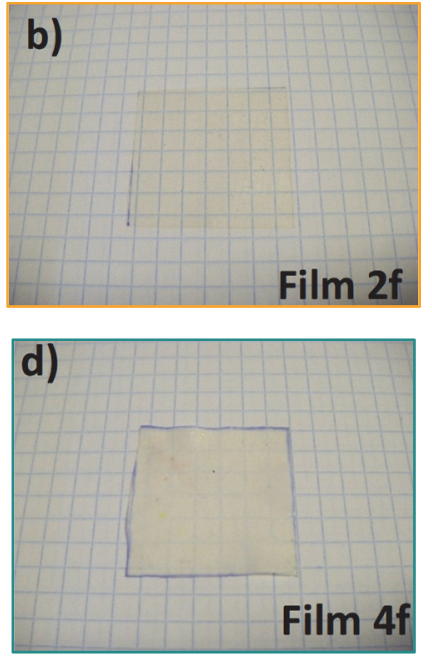

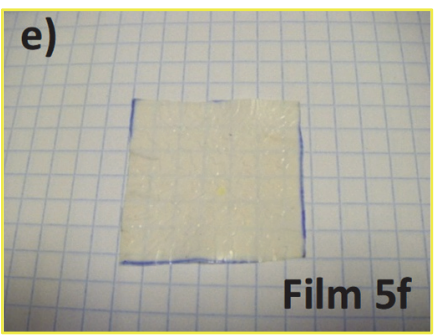

Fig. 3. Photographs of the foamed samples.

The FTIR spectrum of the VP-MMA copolymer is presented in Fig. 4. The characteristic absorption bands of PMMA are clearly visible, the $\mathrm{C}=\mathrm{O}$ stretching vibration of ester group appears around $1726 \mathrm{~cm}^{-1}$, the doublet bands at 1162 and $1113 \mathrm{~cm}^{-1}$ correspond to the $\mathrm{C}-\mathrm{O}$ stretching vibrations of ester groups [29]. The absorptions around $1421 \mathrm{~cm}^{-1}$ characterize the asymmetric bending vibrations of $\mathrm{C}-\mathrm{CH}_{2}$ bond. PVP represents a strong $\mathrm{C}=\mathrm{O}$ absorption peak from the amide group of the copolymer at $1656 \mathrm{~cm}^{-1}$. A medium strong absorption band of the $\mathrm{C}-\mathrm{N}$ group appears at $1268 \mathrm{~cm}^{-1}$, and $\mathrm{C}-\mathrm{H}$ stretching vibration frequencies are observed near $2926 \mathrm{~cm}^{-1}$. The presence of the cross-linking agent can be clearly detected at the peak variation corresponding to the $\mathrm{C}-\mathrm{O}$ stretching vibrations of ester groups at $1113 \mathrm{~cm}^{-1}$, which is progressively reduced when a cross-linking agent is added. A detailed analysis of the peak variation is depicted 
in Table 3, which details the peak displacement and also the peak area variation as a function of the molecular mass of the cross-linker. It can be seen that area of the peak is increased with the molecular mass of the cross-linker, indicating that the molecular vibration associated to this region $(\mathrm{C}-\mathrm{O}$ stretching vibrations of ester groups), is restricted when the molecular structure of the initial copolymer is cross-linked. For example, in sample 2, with PEGDMA 200 in the formulation, the peak disappears completely. It is important to remark that no differences were observed between IR spectra of solid and foamed samples, confirming that during the $\mathrm{ScCO}_{2}$ foaming process the $\mathrm{CO}_{2}$ does not interact or modify chemically the copolymer.
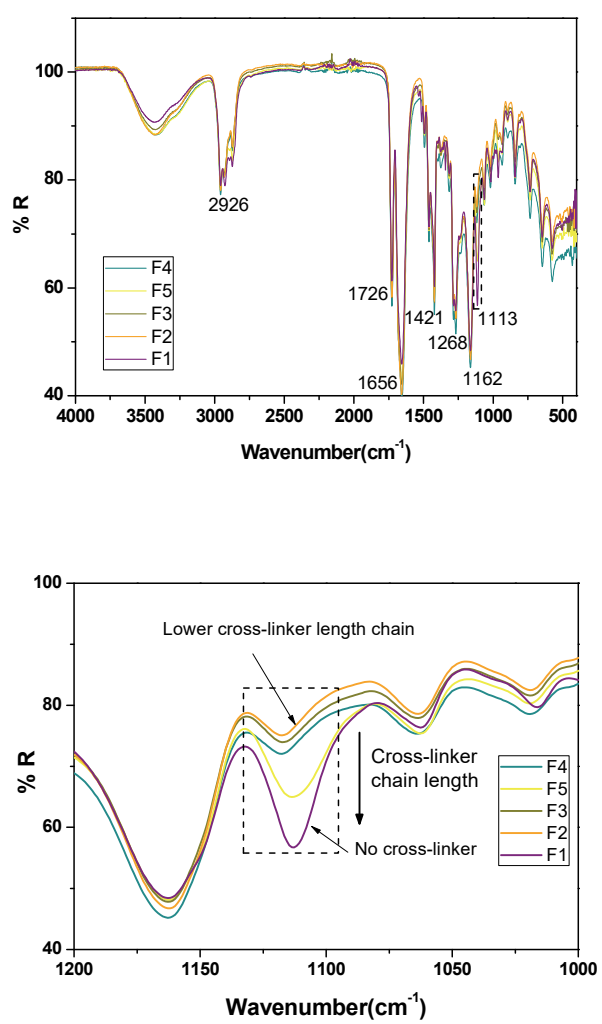

Fig. 4. IR spectra of the solid materials: a) General spectra; b) Detail of the peak variation corresponding to the presence of the cross-linking agent. 
Table 3. Characteristics of the IR absorption peak around $1113 \mathrm{~cm}^{-1}$ in solid films.

\begin{tabular}{c|ccc}
\hline Film number & Cross-linker & $\begin{array}{c}\text { Wavenumber } \\
\left(\mathbf{c m}^{-1}\right)\end{array}$ & Peak area \\
\hline 1 & Not added & 1112.9 & 271.23 \\
2 & PEGDMA $_{200}$ & 1119.0 & 137.21 \\
3 & PEGDMA $_{750}$ & 1117.2 & 142.26 \\
4 & PEGDMA $_{8000}$ & 1115.5 & 159.97 \\
5 & PEGDMA $_{20000}$ & 1113.1 & 251.27 \\
\hline
\end{tabular}

The water-swelling percentage (WSP) was obtained directly from the thermogravimetric curves, by simply measuring the weight variation between RT to $100^{\circ} \mathrm{C}$. It was assumed that the total weight loss during this temperature range was attributed to the water desorption, and no degradation of the copolymer was produced. TGA analysis curves are collected in Fig. 5. The influence of the crosslinker in the WSP can be clearly seen: WSP is drastically reduced when cross linker is added (see Fig. 5 for detail). This behavior is due to the physical increase of the rigidity of the molecular structure due to the addition of the cross-linker, which makes more difficult the water absorption. Moreover, the cross-linking effect is stronger when the molecular mass is reduced (compare curves of samples $2 f$ and $3 f$ with curves of samples $4 f$ and $5 f$ in Fig. 5 ).

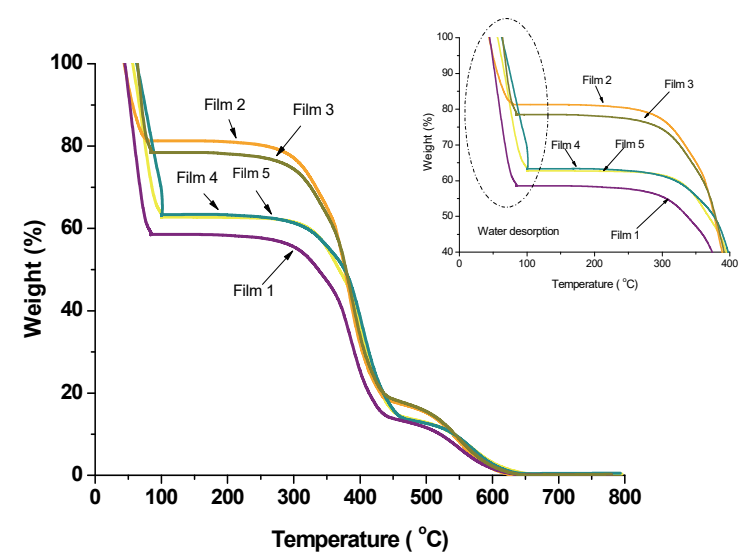

Fig. 5. Thermogravimetric analysis of the foamed films. Inset: detail of the curve between RT and $400^{\circ} \mathrm{C}$. 
To characterize the thermal stability of the films the extrapolated onset temperature, which denotes the temperature at which the copolymer degradation begins, can be also directly calculated from TGA curves. Table 4 quantifies the WSP percentages and onset temperatures in all the films analyzed.

Table 4. Water swelling percentage (WSP) and onset temperature of the foamed films obtained from TGA measurements (all tests performed in $\mathrm{N}_{2}$ atmosphere).

\begin{tabular}{|c|cc|}
\hline Film number & WSP (\%) & Onset temperature $\left({ }^{\circ} \mathbf{C}\right)$ \\
\hline $1 f$ & 42 & 359 \\
$2 f$ & 19 & 383 \\
$3 f$ & 22 & 378 \\
$4 f$ & 37 & 371 \\
$5 f$ & 38 & 361 \\
\hline
\end{tabular}

The obtained data show that values of WSP vary between $19 \%$ and $42 \%$, with a clear influence of the presence of the cross-linker (reported WSP values in similar non-cross-linked films are around $60 \%$ [22], which indicates that the cross-linker reduces greatly the WSP). It can be seen that adding short chain length PEGDMA, (film 2f, with PEGDMA200), decreases the WSP respect to film 1f (without cross-linker) from $42 \%$ to $19 \%$. This effect is reduced when the molecular weight of PEGDMA is increased (see films $4 \mathrm{f}$ and $5 \mathrm{f}$, with PEGDMA 8000 and PEDGMA20000, respectively), which shows only slight differences in WSP values respect to film 1f. In this case, the addition of PEGDMA 8000 and PEGDMA 20000 , increases the WSP due to the hydrophilicity of the cross-linker.

The enhanced rigidity of the films due to the cross-linker addition increases slightly the onset temperature values (between 359 and $383^{\circ} \mathrm{C}$ ). Film 2, with PEGDMA $_{200}$ in the formulation, presented the highest thermal stability, up to $24{ }^{\circ} \mathrm{C}$ higher than film 1 , (without cross-linker in the formulation). The effect of the molecular mass of the cross-linker is also evidenced in the onset temperature variation, which decreases from 383 to $361^{\circ} \mathrm{C}$ in films 2 to 5 when increasing the molecular mass of PEGDMA from 200 to 20000. 
Fig. 6 presents the SEM micrographs obtained from samples in the thickness direction. As it can be seen, the addition of PEGDMA 200 in the initial copolymer formulation blocks the foaming process, and as a result, solid samples with no cell structure are obtained (Fig. 6b). However, increasing the molecular weight of the PEGDMA leads to the formation of cellular structures, allowing the foaming of the samples, even when a cross-linked structure is formed in the initial solid sample.

Fig. 6 a presents the cellular structure of sample 1f, with no cross-linker added, in which a bi-modal cellular structure can be appreciated, probably due to the different affinity and diffusivity of the $\mathrm{CO}_{2}$ into the MMA and VP monomers [25].

This bi-modal structure disappears when the cross-linker is introduced, obtaining a more homogeneous cellular morphology. The inclusion of the cross-linker increases the rigidity of the molecular structure and could limit the bubble expansion equally, thus homogenizing the final bubble radius.

Finally, in Fig. $6 f$ an overview of the thickness expansion in sample $5 f$ is presented, where it can be seen that final thickness of the foamed films is about $120 \mu \mathrm{m}$, indicating an expansion ratio of approximately $20 \%$ respect to the initial thickness of $100 \mu \mathrm{m}$. In addition, a very thin solid outer skin with a thickness between approximately 5 and $10 \mu \mathrm{m}$ can be detected. This type of skin was observed in all the samples. 

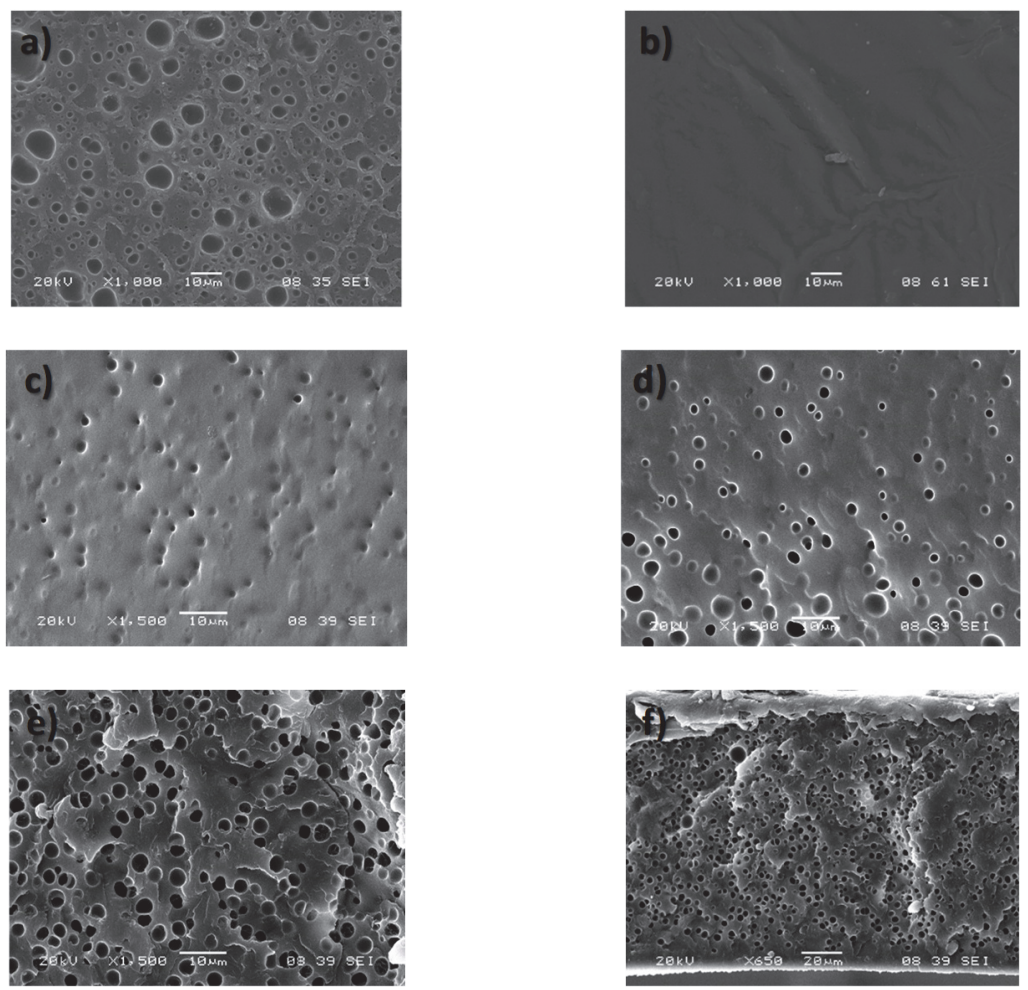

Fig. 6. SEM micrographs of the foamed samples: a) sample 1f; b) sample 2f; c) sample $3 f$; d) sample 4f; e) sample $5 f$; f) overview of thickness expansion in sample $5 f$.

As shown in Fig. 6c-e, a correlation between the molecular weight of the crosslinker and the morphological parameters, cell density and cell size, is observed. The quantification of both parameters was carried out using the Image $J^{\circledR}$ software, from Eqs. (1) and (2). Results are summarized in Table 5.

Table 5. Morphological parameters of the foamed films

\begin{tabular}{c|ccccc}
\hline $\begin{array}{c}\text { Film } \\
\text { number }\end{array}$ & $\overline{\mathbf{R}}(\boldsymbol{\mu m})$ & Desv. Std & $\mathbf{n}$ & $\mathbf{A}\left(\boldsymbol{\mu m}^{2}\right)$ & $\mathbf{N}_{\mathbf{c}}\left(\mathbf{c m}^{-3}\right)$ \\
\hline $1 \mathrm{f}$ & 5.34 & 0.980 & 256 & 11408 & $2.24 \cdot 10^{6}$ \\
$2 \mathrm{f}$ & $\mathrm{N} / \mathrm{A}$ & $\mathrm{N} / \mathrm{A}$ & $\mathrm{N} / \mathrm{A}$ & 11408 & $\mathrm{~N} / \mathrm{A}$ \\
$3 \mathrm{f}$ & 1.02 & 0.013 & 134 & 11408 & $1.17 \cdot 10^{6}$ \\
$4 \mathrm{f}$ & 2.98 & 0.230 & 157 & 11408 & $1.37 \cdot 10^{6}$ \\
$5 \mathrm{f}$ & 4.02 & 0.091 & 298 & 11408 & $2.61 \cdot 10^{6}$ \\
$\bar{R}$ indicates & the average cell radius; $n$ indicates the bubble count number; \\
$A$ indicates the micrograph area; $N_{c}$ indicates the cell density. &
\end{tabular}


Average cell size shows values between 1.02 and $5.34 \mu \mathrm{m}$, except sample 2, in which no cellular structure is present, due to the addition of the PEGDMA 200 . Increasing the molecular weight of the cross-linker results in higher average cell sizes. Also, the standard deviation value is higher in sample $1 \mathrm{f}$, without crosslinker, presenting a bi-modal cell structure. It is interesting to remark that the addition of the cross-linker reduces the standard deviation value of the average cell radius, homogenizing the cellular structure and also increasing the cell density. This could be due to the good $\mathrm{CO}_{2}$-philicity of the methacrylate groups of the cross-linker, which increases the nucleation sites during saturation process, then reducing the cell size, avoiding coalescence and also increasing the final value of the cell density. Concerning the calculation of cell density $N_{c}$, the obtained values also increase with $M_{n}$, lying in the microcellular range $N_{c} \approx$ $10^{6}$. The dependence of $\bar{R}$ and $N_{c}$ with $M_{n}$ is represented in Fig. 7, in which is evidenced the influence of the molecular weight of the cross-linker in the cellular structure of the foamed films.

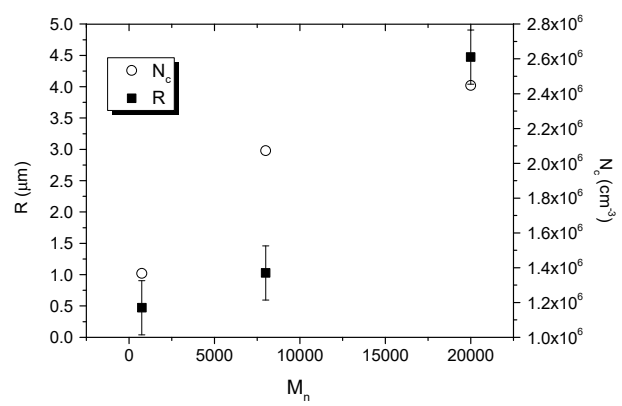

Fig. 7. Dependence of average cell size and cell density with the molecular mass of the cross-linker.

Tensile tests were performed in the microcellular films at low velocity $(5 \mathrm{~mm} / \mathrm{min})$ to evaluate the influence of the cross-linking agent in different mechanical parameters. Young's modulus, stress and deformation at break point were determined for all the films fabricated. Fig. 8 shows the stress-strain $(\sigma-\varepsilon)$ curves for films $1 f$ to $5 f$. 


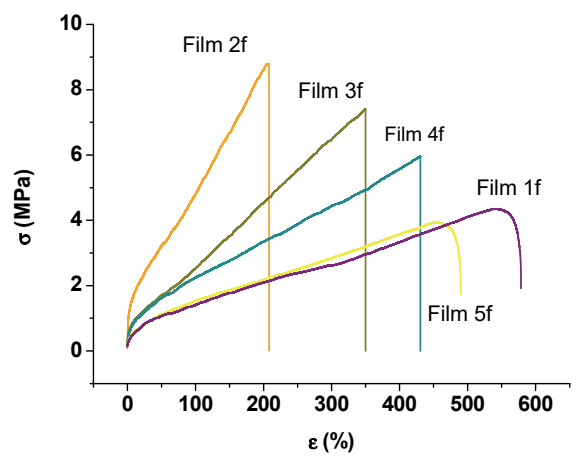

Fig. 8. Stress-strain curves obtained from tensile tests at $5 \mathrm{~mm} / \mathrm{min}$.

As expected, the addition of the cross-linker agent increases the rigidity of the films. Film $1 \mathrm{f}$ shows a ductile behavior, with larger deformation at break. Also, film If shows a ductile behavior at the end of the test. On the other hand, films $2 f-4 f$ present a typical rigid behavior, with no ductility, and lower values of deformation at break. It is clear that reducing the molecular mass of the cross-linker increases the rigidity of the film, and subsequently, higher young's moduli values are expected. However, film 5f, with PEGDMA20000 in the formulation, does not present a very different behavior from film $1 \mathrm{f}$ (with no cross-linker added). The quantification of the mechanical parameters is presented in Table 6. For calculation purposes, the Young's modulus was obtained from the slope of the linear range of the stress-strain curve. In all the cases, the linear region was determined numerically, lying in the deformation range $\varepsilon$ from $0.05 \%$ (in the case of film 2) to $0.1 \%$ (in the case of film 1). The fitting parameter $r^{2}$ was higher than 0.98 in all the calculations performed. Data presented in Table 6 show, for example, that Young's modulus increases up to one hundred times from film $1 \mathrm{f}$ to film $2 \mathrm{f}$ ( 0.01 to $0.98 \mathrm{MPa}$, respectively). Stress at break point also varies from 1.92 to $8.80 \mathrm{MPa}$ and elongation at break decreases from $578 \%$ to $208 \%$ due to the presence of PEGDMA 200 . The addition of PEGDMA 20000 does not affect significantly to the VP-MMA copolymer, and films $1 f$ and $5 f$ present similar values of $E, \sigma^{\text {break point }}$ and $\varepsilon^{\text {break point }}$. 
Table 6. Mechanical parameters of the foamed films obtained from tensile tests at 5 $\mathrm{mm} / \mathrm{min}$

\begin{tabular}{c|ccc} 
Film number & E (MPa) & $\sigma^{\text {break point }}(\mathbf{M P a})$ & $\varepsilon^{\text {break point }}(\%)$ \\
\hline $1 f$ & 0.01 & 1.92 & 578 \\
$2 f$ & 0.98 & 8.80 & 208 \\
$3 f$ & 0.67 & 7.41 & 350 \\
$4 f$ & 0.25 & 5.96 & 431 \\
$5 f$ & 0.11 & 1.73 & 489
\end{tabular}

Fig. 9 evaluates the influence of the molecular mass of the cross-linking agents in the Young's modulus. The experimental values can be fitted using an exponential decay curve, with a value of $r^{2}$ of 0.9785 . Assuming that the absence of cross-linker agent can be equivalent to an addition of a cross-linker of $M_{n} \rightarrow \infty$, the estimated value of $E$ in the theoretical calculation $\left(E_{0}\right)$ is equal to $0.087 \mathrm{MPa}$, which is in the same order of magnitude than the experimental value found in film 1 , with no cross-linker added $\left(E_{\text {film } 1 f}=0.01 \mathrm{MPa}\right)$. On the other hand, a crosslinker of very short molecular mass, (thus $M_{n} \rightarrow 0$ ), can be assumed as the limit case in which the composition of the film is $100 \%$ cross-linker. In this case, the theoretical value for $E$ is equal to $A=5.081 \mathrm{MPa}$. To correlate this limit value with experimental data, an additional tensile test was performed in a solid film with composition $100 \%$ of PEDGMA200, obtaining a Young's modulus value $E$ of 6.74 MPa. Taking into account these approximations, we can conclude that using this simple theoretical correlation, the mechanical properties of cross-linked microcellular films can be estimated as a function of the molecular mass of the cross-linker employed.

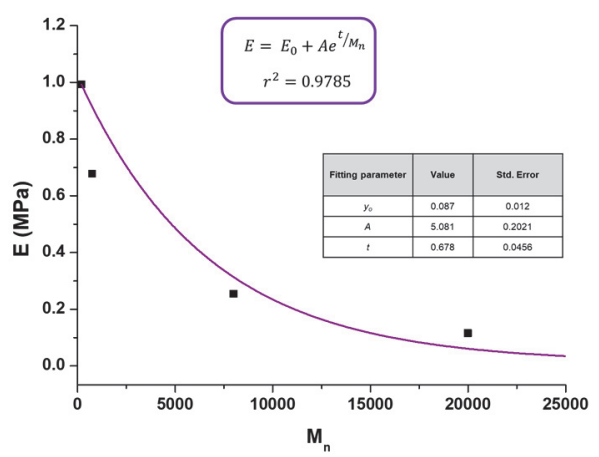

Fig. 9. Young's modulus as function of mass number average of the cross-linker. 


\section{Conclusions}

In short, different microcellular polymeric films have been produced using the $\mathrm{ScCO}_{2}$ gas dissolution foaming process. A formulation based on 1-vinyl-2pyrrolidone and methyl-methacrylate was modified by adding a cross-linker agent, poly(ethylene glycol) dimethacrylate, with different average molecular masses, to evaluate the influence of this parameter in the foaming behavior and in different physical properties, such as thermal stability, water swelling percentage and tensile properties. The IR spectra of the solid films showed a peak variation at $1113 \mathrm{~cm}^{-1}$, corresponding to the presence of the cross-linker. It was also found that peak area was directly related to the molecular weight of the cross-linker. The influence of the cross-linker was evaluated in the thermal stability and water-swelling percentage from thermogravimetric analysis. It was observed that the addition of the cross-linker decreases the water absorption and, at the same time, increases the thermal stability of the films. Both parameters could be controlled by varying the molecular mass of the cross-linker. Next, microcellular films were fabricated using $\mathrm{CO}_{2}$ gas dissolution process. It is well known that cross-linking hinders the $\mathrm{CO}_{2}$ sorption, but in our work, it was observed a good foamability in films with cross-linker of long chain length. In addition, microcellular morphological parameters such as cell density could be tuned as a function of the molecular mass of the cross-linker, increasing as the value of $M_{n}$ was higher. The films produced presented average cell sizes between 1 and $5 \mu \mathrm{m}$ and cell density values lying in the microcellular range $\left(\approx 10^{6} \mathrm{~cm}^{-3}\right)$. Finally, the mechanical properties of the films were analyzed by means of lowvelocity tensile tests. Microcellular films with cross-linker in their formulation presented an increased rigidity, with higher Young modulus values and lower deformations at break. The influence of the molecular weight of the cross-linker was evaluated and predicted theoretically from the experimental data, correlating the molecular weight of the cross-linker with the Young modulus of the microcellular films. 


\section{Acknowledgments}

The financial support provided by the Fondo Europeo de Desarrollo Regional (FEDER) and the Spanish Agencia Estatal de Investigación (AEI) (MAT2017$84501-R)$ is gratefully acknowledged.

\section{References}

[1] J.A.R. Ruiz, M. Pedros, J.M. Tallon, M. Dumon, J. Supercrit. Fluids. 2011, 58, 168-176.

[2] S. Costeux, J. Appl. Polym. Sci. 2014, 131, 41293(1)-41293(16).

[3] B. Notario, J. Pinto, E. Solorzano, J.A. De Saja, M. Dumon, M.A. Rodríguez-Pérez, 2015, 56, 57-67.

[4] C. Forest, P. Chaumont, P. Cassagnau, B. Swoboda, P. Sonntag, Prog. Polym. Sci. 2015, 41, $122-145$.

[5] J.A. Reglero Ruiz, S. Vallejos, A.M. Sanjuán, F.C. García, M. Múgica, M.A. Rodríguez-Pérez, J.M. García, J. Appl. Polym. Sci. 2017, 135, 45872(1)-45872(7).

[6] B. Notario, J. Pinto, M.A. Rodríguez-Pérez, Prog. Mater. Sci. 2016, 78-79, 93-139.

[7] S. Siripurapu, J.A. Coughlan, R.J. Spontak, S.A. Khan, Macromolecules 2004, 37, 9872-9879.

[8] X.K. Li, G.P. Cao, L.H. Chen, R.H. Zhang, H.L. Liu, Y.H. Shi, Langmuir 2013, 29, 14089-14100.

[9] S. Siripurapu, J.M. DeSimone, S.A. Khan, R.J. Spontak, Adv. Mater. 2004, 16, 989-994

[10] S. Siripurapu, J.M. Desimone, R.J. Spontak, S.A. Khan, Fuel Chem. Div. Prepr. 2003, 48, 262 263.

[11] S. Siripurapu, J.M. DeSimone, S.A. Khan, R.J. Spontak, Macromolecules 2005, 38, 2271-2280.

[12] C. Yang, Z. Xing, M. Zhang, Q. Zhao, M. Wang, G. Wu, Radiat. Phys. Chem. 2017, 141, 276283.

[13] Z. Jiang, K. Yao, Z. Du, J. Xue, T. Tang, W. Liu, Compos. Sci. Technol. 2014, 97, 74-80.

[14] F. Rindfleisch, T.P. DiNoia, M.A. McHugh, J. Phys. Chem. 1996, 100, 15581-15587.

[15] C. Yang, X. Zhe, M. Zhang, M. Wang, G. Wu, Radiat. Phys. Chem. 2017, 131, 35-40.

[16] D.B. Días, L.G. de Andrade e Silva, Radiat. Phys. Chem. 2007, 76, 1696-1697.

[17] L.O. Salmazo, A. López-Gil, Z.M. Ariff, A.E. Job, M.A. Rodríguez-Pérez, Ind. Crops Prod. 2016, $89,339-349$.

[18] J.B. Bao, A. Nyantakyi Junior, G.S. Weng, J. Wang, Y.W. Fang, G.H. Hu, J. Supercrit. Fluids. 2016, 111, 63-73.

[19] C. Okolieocha, F. Beckert, M. Herling, J. Breu, R. Mülhaupt, V. Altstädt, Compos. Sci. Technol. 2015, 118, 108-116.

[20] D. Miller, V. Kumar, Tensile and impact properties, 2011, 52, 2910-2919.

[21] G. Wang, J. Zhao, L.H. Mark, G. Wang, K. Yu, C. Wang, C.B. Park, G. Zhao, Chem. Eng. J. 2017, 325, 632-646.

[22] S. Vallejos, J. Antonio Reglero, F. Clemente García, J. M. García, J. Mater. Chem. A, 2017, 5, 13710-13716.

[23] J.A.R. Ruiz, J. Marc-Tallon, M. Pedros, M. Dumon, J. Supercrit. Fluids 2011, 57, 87-94.

[24] V. Bernardo, J. Martín-de León, E. Laguna-Gutiérrez, M.A. Rodríguez-Pérez, Euro. Polym. J. 2017, 96, 10-26.

[25] M.M. Hasan, Y.G. Li, G. Li, C.B. Park, J. Chem. Eng. Data 2010, 55, 4885-4895.

[26] K.F. Webb, A.S. Teja, Fluid Phase Equilib. , 1999, 158-160, 1029-1034.

[27] A.C. Galvao, A.Z. Francesconi, J. Chem. Thermodyn. 2010, 42, 684-688.

[28] J. Martín-de León, V. Bernardo, M.A. Rodríguez-Pérez, Macromol. Mater. Eng. 2017, 302, 1700343(1)-1700343(5).

[29] M. Benadda, M.I. Ferrahi, M. Belbachir, Bull. Chem. Reac. Eng. Cat. 2014, 9, 201-206. 
Microcellular foamed aromatic polyamides (aramids). Structure, thermal and mechanical properties 



\title{
Microcellular foamed aromatic polyamides (aramids). Structure, thermal and mechanical properties.
}

\author{
Blanca S. Pascuala, Miriam Trigo-López ${ }^{a}$, Cipriano Ramos ${ }^{b}$, María Teresa \\ Sanz ${ }^{b}$, Jesús L. Pablos ${ }^{c}$, Félix C. García ${ }^{a}$, José A. Reglero Ruiz ${ }^{a,{ }^{*}}$ and José \\ Miguel García \\ a Departamento de Química, Facultad de Ciencias, Universidad de Burgos, Plaza de Misael \\ Bañuelos s/n, 09001 Burgos, Spain. \\ b Departamento de Biotecnología y Ciencia de los Alimentos, Área de Ingeniería Química, Facultad \\ de Ciencias, Universidad de Burgos, Plaza de Misael Bañuelos s/n, 09001 Burgos, Spain. \\ ${ }^{c}$ Instituto de Ciencia y Tecnología de Polímeros, Consejo Superior de Investigaciones Científicas, \\ ICTP-CSIC, Juan de la Cierva 3, 28006 Madrid, Spain.
}

\begin{abstract}
We have deeply diminished the density of high-performance aromatic polyamides or aramids. Thus, we have prepared microcellular films that at the same time maintain the outstanding thermal and mechanical properties characteristic of these high performance materials. Two different cellular aramids were produced, based on commercial poly ( $m$-phenylene isophthalamide), one of them with an additional azide group. Microcellular structures have been obtained by adding ionic liquids combined to $\mathrm{ScCO}_{2}$ foaming process, with cell sizes between 0.6 and $4.7 \mu \mathrm{m}$ and cell densities between $10^{9}$ and $10^{11} \mathrm{cells}^{3} \mathrm{~cm}^{3}$. The density was lowered for the commercial poly ( $m$-phenylene isophthalamide) (Nomex ${ }^{\circledR}$ and Teijin Conex ${ }^{\circledR}$ ) from 1.43 to $0.62 \mathrm{~g} \mathrm{~cm}^{-3}$ and from 1.48 to $0.31 \mathrm{~g} \mathrm{~cm}^{-3}$ for the aramid containing the azide group. Foams present the following thermal and mechanical properties: $5 \%$ weight loss observed at $\mathrm{T}>400{ }^{\circ} \mathrm{C}$ and relative Young modulus and tensile strength of $1.2 \mathrm{GPa}\left(\mathrm{g} \mathrm{cm}^{-3}\right)^{-1}$ and $60 \mathrm{MPa}\left(\mathrm{g} \mathrm{cm}^{-3}\right)^{-1}$, respectively.
\end{abstract}




\section{Introduction}

Aromatic polyamides, or aramids, are high performance materials characterized by their outstanding mechanical properties and by their superior thermal resistance. High value added goods are prepared with aramid-fibers, such as advanced human-protection clothing, high-temperature isolation paper and advanced composites [1].The success of commercial aramids, namely poly $(m-$ phenylene isophthalamide) (MPIA) (main brand names: Nomex ${ }^{\circledR}$ and Teijin Conex $^{\circledR}$ ) and poly ( $p$-phenylene terephthalamide) (PPTA) (main brand names: $\operatorname{Kevlar}^{\circledR}$ and Twaron $\left.^{\circledR}\right)$, relay on their thermal and mechanical behavior and also on their low density compared with other inorganic fibers, carbon fiber, ceramics and metals [2]. This is especially important in aeronautic and automotive industry, but also in human protection clothing to prepare lightweight and high strength materials.

For the sake of lowering weight, the foaming of metals and polymers is a topic of current interest $[3,4]$, and this is especially true for aramids, where preparation of foamed aramids has not been reported.

Cellular materials, especially cellular polymers or polymer foams, have been analyzed during several decades due to their unique combination of thermal, mechanical and acoustical properties with low weight [5]. In the last years, efforts have been carried out in the production of cellular polymers with controlled morphology, to obtain polymer foams with specific properties that can be easily fabricated in industrial processes for different applications. Polymer foams can be described in terms of their density, average cell size and cell density. In case of microcellular polymers, they are characterized for having average cell size between 1 and $100 \mu \mathrm{m}$, with cell densities in the range of $10^{6}-10^{10}$ cells $\mathrm{cm}^{-3}$. Reducing the cell size below $1 \mu \mathrm{m}$ originates sub-micro cellular foams, with cell densities above $10^{11}$ cells $\mathrm{cm}^{-3}$. The reduction of the cell size has gained a lot of interest, producing, for example, super-isolating materials or polymers with ultralow dielectric properties, $[6,7]$. 
The use of supercritical $\mathrm{CO}_{2}\left(\mathrm{ScCO}_{2}\right)$ as green foaming agent has revealed as the most promising technique to obtain polymer foams with controlled morphology $[8,9]$. Regarding engineering polymers, different approaches have been employed to improve both the $\mathrm{CO}_{2}$ absorption and their foaming capability. One of these research lines is focused in the use of ionic liquids (ILs) due to the good compatibility combined to the enhancement of $\mathrm{CO}_{2}$ absorption [10-15].

Combining all the previous ideas, the main objective of this work was filling the lack of microcellular aramids, foaming them with $\mathrm{ScCO}_{2}$ using ILs as $\mathrm{CO}_{2}$ absorption promoters $[16,17]$.

\section{Experimental}

\subsection{Materials and instrumentation}

1-allyl-3-methylimidazolium chloride ( $\geq 97 \%$ ) was used as ionic liquid (IL). N,Ndimethylacetamide (DMAc, $99 \%$ ) was employed as solvent to obtain the polyamide films. Both chemicals were purchased from Sigma-Aldrich and used as received. The rest of the materials employed to synthetize the raw polyamides can be found in our previous work [18].

Thermogravimetric analysis data of the polyamide films were recorded on a TA Instrument Q50 TGA analyzer, whereas Differential Scanning Calorimetry (DSC) measurements were carried out in a DSC Q200 TA Instruments equipment.

Foaming took place in a single-step batch process using $\mathrm{ScCO}_{2}$. Films were saturated in a high-pressure reactor of $2 \mathrm{~L}$ of capacity, at a controlled pressure and temperature. After saturation, depressurization took place by opening a manual valve placed at the top of the reactor.Cellular structural determination of the microcellular films was carried out in a scanning electron microscopy model JEOL JSM-6460LV.

Finally, the tensile tests of the polyamide films were performed on a SHIMADZU EZ Test Compact Table-Top Universal Tester. Mechanical clamps were using a gauge length of $9.44 \mathrm{~mm}$. 


\subsection{Synthesis of aromatic polyamides and preparation of films}

Aromatic polyamides PA1 and PA2 were prepared and purified following the procedures described in our previous work [19]. Also, in polyamide PA2, the reactive azide group introduced into the structure leads to a crosslinking effect following a simple an inexpensive heat treatment $\left(240{ }^{\circ} \mathrm{C}\right.$ during $\left.10 \mathrm{~min}\right)$.

To prepare the polyamide films with ionic liquids a simple procedure was followed: $0.2 \mathrm{~g}$ of PA1 or PA2 was dissolved in $2.85 \mathrm{~mL}$ of DMAc and stirred until full dissolution of the polyamide. Then, $50 \%$ weight percent (wt.) of the ionic liquid was added to the solution and stirred for an additional hour. The mixture was then filtered off and cast in a glass placed inside an air-circulating oven at $60{ }^{\circ} \mathrm{C}$ for $12 \mathrm{~h}$.

Three different groups of non-foamed films were fabricated. A first group of films without ionic liquid, a second group with $50 \%$ wt. of ionic liquid, and a third group of films in which the ionic liquid was eliminated in distilled water during $24 \mathrm{~h}$, to also evaluate the influence of the ionic liquid in the mechanical and thermal properties.

\section{3. $\mathrm{ScCO}_{2}$ foaming process}

Foaming took place in a single-step batch process using $\mathrm{ScCO}_{2}$. Films were cut in pieces of $40 \times 40 \mathrm{~mm}^{2}$ and, sandwiched between 2 square steel plates ( $50 \mathrm{x}$ $50 \mathrm{~mm}^{2}$ and $2 \mathrm{~mm}$ thickness), to confine the gas during depressurization, thus limiting the gas diffusion process outside the material. Films were saturated in the high-pressure reactor at $35 \mathrm{MPa}$ and $60{ }^{\circ} \mathrm{C}$ during $8 \mathrm{~h}$. Depressurization was carried out using a manual opening valve, with a depressurization time of about $10 \mathrm{~s}$.

\subsection{Cellular characterization and density determination}

Films were frozen in liquid nitrogen, fractured and gold coated in vacuum to assure the electrical conductivity of the films. Cellular structural characterization determining the average bubble radius from SEM images, measured using the 
Image ${ }^{\circledR}$ software, counting the number of bubbles in each image $n_{i}$ and its radius $R_{i}$. The average radius $\bar{R}$ is calculated from Eq. (1):

$$
\bar{R}=\frac{\sum_{i=1}^{N} n_{i} R_{i}}{\sum_{i=1}^{N} n_{i}}
$$

where $N$ represents the bubble count. Five different SEM images were analyzed from each material, averaging the data. The estimation of the cell density $N_{c}$ was calculated using the Kumar's approximation, according to Eq. (2):

$$
N_{c}=\left(\frac{n}{A}\right)^{3 / 2}
$$

where $n$ is the number of cells in the image and $A$ is the area of the image. Taking into account the average radius value and cell density, the gas volume fraction $V_{f}$ was obtained using Eq. (3):

$$
V_{f}=\frac{\pi \bar{d}^{3} N_{c}}{6}
$$

where $\bar{d}$ is the average diameter. Then, gas volume fraction $V_{f}$ and foam density $\rho^{S E M}$ are related throughout Eq. (4), in which $\rho_{s}$ is the solid material density:

$$
V_{f}=1-\frac{\rho^{S E M}}{\rho_{s}}
$$

\subsection{Thermal properties}

Differential scanning calorimetry (DSC) was performed to evaluate the thermal transitions of the materials. Tests were carried out following a four-cycle procedure. First, after $5 \mathrm{~min}$ of stabilization at $30^{\circ} \mathrm{C}$, films were heated up to $350{ }^{\circ} \mathrm{C}$ at $20{ }^{\circ} \mathrm{C} \mathrm{min}-1$. Then, after $5 \mathrm{~min}$ of stabilization at $350{ }^{\circ} \mathrm{C}$, films were cooled down to RT at the same rate. Third, a second heating cycle was performed following the same conditions of the first cycle, concluding with a final cycle to cool down the samples to RT at $20{ }^{\circ} \mathrm{C} \mathrm{min}^{-1}$. All the tests were performed under $\mathrm{N}_{2}$ atmosphere (flow rate $50 \mathrm{~mL} \mathrm{~min}^{-1}$ ). Mass of the films was fixed at approximately $20 \mathrm{mg}$ in each test.

The thermal stability was determined by thermogravimetric analysis (TGA). Films 
were first dried in vacuum overnight at $40^{\circ} \mathrm{C}$, and then TGA tests were performed under $\mathrm{O}_{2}$ atmosphere using the next procedure: First, films were heated from RT to $100{ }^{\circ} \mathrm{C}$ at $10^{\circ} \mathrm{C} \mathrm{min}^{-1}$, and then kept during $5 \mathrm{~min}$ to eliminate the moisture content. Finally, TGA analysis was completed by heating up to $800{ }^{\circ} \mathrm{C}$ at $10{ }^{\circ} \mathrm{C} \cdot \mathrm{min}^{-1}$. Additionally, the crosslinking effect of PA2 was analyzed performing a TGA following the conditions of the crosslinking process. PA2 was heated from RT to $100{ }^{\circ} \mathrm{C}$ at $10^{\circ} \mathrm{C} \mathrm{min}^{-1}$, then kept during $5 \mathrm{~min}$, and heated up to $240{ }^{\circ} \mathrm{C}$ at $10{ }^{\circ} \mathrm{C} \mathrm{min}^{-1}$.

Crosslinking process was performed by keeping the sample at $240{ }^{\circ} \mathrm{C}$ during 10 $\mathrm{min}$, and then the analysis was completed by heating up to $800{ }^{\circ} \mathrm{C}$ at $10^{\circ} \mathrm{C} \mathrm{min}^{-1}$. Samples were weighted approximately at $10 \mathrm{mg}$.

\subsection{Tensile tests}

Low velocity tensile tests $\left(5 \mathrm{~mm} \mathrm{~min}^{-1}\right)$ were performed in the microcellular films to evaluate the influence of cells in different mechanical parameters (Young's modulus and stress and deformation at break point). 5 strips of $5 \mathrm{~mm}$ width and $40 \mathrm{~mm}$ length were tested for each film, averaging the data.

\section{Results and discussion}

Two different aromatic polyamides were casted into films and foamed. One of the aramids is the commercial MPIA (PA1) and the other one a functional MPIA containing an azide group in the main polymer chain (PA2) that allows for the crosslinking of the materials, after foaming, for superior thermal and mechanical performance (Scheme 1) [18,19].

The foaming was achieved by using conventional $\mathrm{ScCO}_{2}$ foaming procedure. The influence of the ILs and the crosslinking process is investigated in terms of the cellular structure, mechanical and thermal properties. 
<smiles>[X]C(C)(C)Nc1cccc(NC(=O)c2cccc(C(C)(C)C)c2)c1</smiles>

PA1<smiles>[Y][Y9]=[W]</smiles>

Scheme 1. Chemical structure of the synthetized polyamides.

Two dense aromatic polyamide films were prepared by casting, F_PA1 and F_PA2, which had conventional densities for aramids. Also, two films were prepared having $50 \% \mathrm{wt}$. of the ionic liquid 1-allyl-3-methylimidazolium chloride, namely F_50PA1/50IL and F_50PA2/50IL. It is important to remark that in a preliminary study, different ionic liquids added in several proportions were tested, but not foaming in $\mathrm{ScCO}_{2}$ was observed in samples with proportions of ionic liquids below $50 \%$ wt. Thus, a fixed proportion of $50 \%$ wt. was employed using this specific ionic liquid.

The removal with water of the $\mathrm{IL}$ from these films rendered the films F_50PA1/50IL-R and F_50PA2/50IL-R. Surprisingly, these films prepared with IL showed low density. We expected low density of the films upon foaming with $\mathrm{ScCO}_{2}$ and not before. The films gave rise themselves to microcellular materials, explained by a thermally induced phase separation after taking them out of the oven. The reason was clear after analyzing the morphology of the films by SEM (Fig. 1), were a microcellular structure was observed for films F_50PA1/50IL and F_50PA2/50IL. Next, the removal of the ionic liquid through the immersion of the film in distilled water during $24 \mathrm{~h}$, films F_50PA1/50IL-R and F_50PA2/50IL-R, causes the development of new pores and a reduction of the average cell radius, thus increasing the cell density. Thus, it was possible to obtain an initial 
microcellular structure just by using the ILs before the $\mathrm{ScCO}_{2}$ treatment (we will denote these films as non-foamed films). This could be explained by a thermally induced phase separation process, which has been classically employed to produce porous membranes [20].
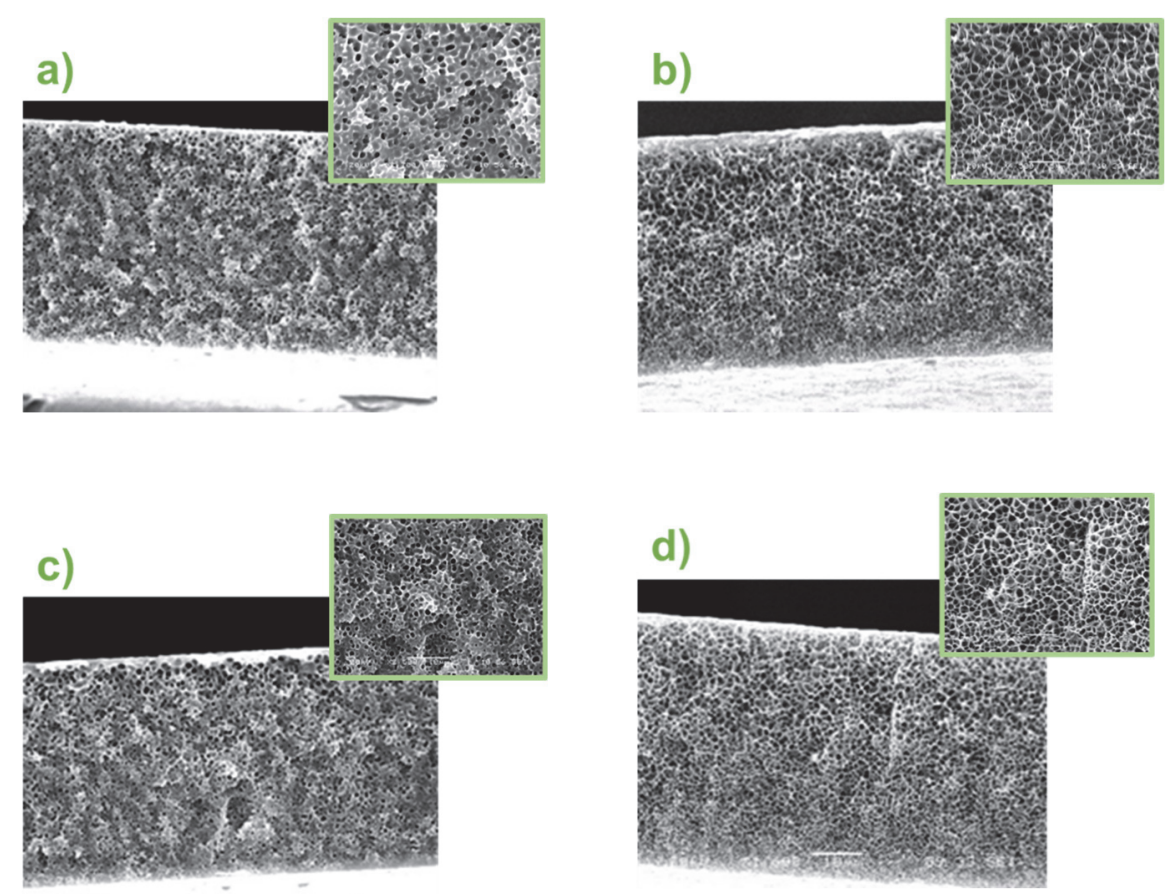

Fig. 1. SEM micrographs of: a) F_50PA1/50IL; b) F_50PA1/50IL-R; c) F_50PA2/50IL; d) F_50PA2/50IL-R. Bar scale $10 \mu \mathrm{m}$.

Then, further treatment with $\mathrm{ScCO}_{2}$ of films with ILs render foamed materials with even a more interesting morphology. We present in Fig. 2 the SEM micrographs of all the foamed aramid films, before and after the removal of the ionic liquid. It can be seen that all aramid films present a very homogeneous structure, observing a closed-cell structure in the case of polymers derived from PA1 (Fig. 2(a) and (b)) and an open-cell structure for materials prepared from PA2 (Fig. 2(c) and (d)). It is also evidenced that removing the ionic liquid does not affect significantly to the microcellular structure, when comparing Fig. 2(a) with Fig. 2(b) (Films (F_50PA1/50IL)f and (F_50PA1/50IL-R)f), and also Fig. 2(c) with Fig. 2(d) 
(Films (F_50PA2/50IL)f and (F_50PA2/50IL-R $\left.)_{f}\right)$. Finally, the heating of F_(50PA2/50IL-R)f at $240{ }^{\circ} \mathrm{C}$ for $10 \mathrm{~min}$ render the crosslinked foam $\left(\right.$ F_50PA2/50IL-R) $\mathrm{f}^{\mathrm{c}}($ See Fig. 2(e)) [19].

a)

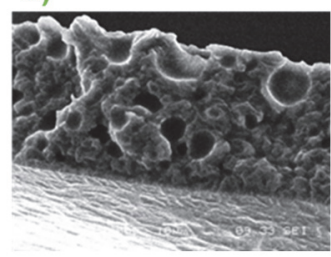

c)

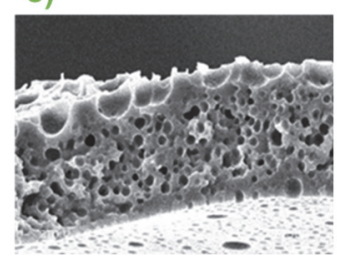

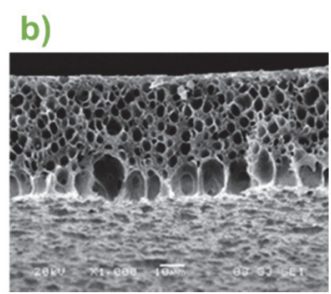

d)

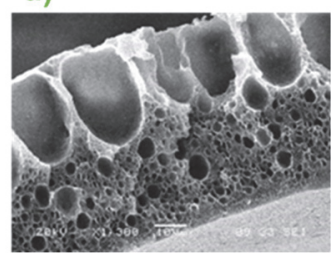

e)

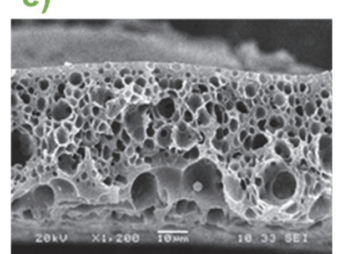

Fig. 2. SEM micrographs of the foamed films based on PA1 and PA2: a) F_50PA1/50IL); b) (F_50PA1/50IL-R)f; c) (F_50PA2/50IL); d) (F_50PA2/50IL-R)f; e) $\left(\bar{F} \_50 P A 2 / 50 \mid L-R\right) f^{c}$. Bar scale: $10 \mu \mathrm{m}$ in all figures.

Table 1 describes the nomenclature and morphological parameters calculated of all the films. The density values estimated from the morphological parameters $\left(\rho^{\mathrm{SEM}}\right)$ are in the same order of magnitude, with a small overestimation, that the density measured experimentally from the dimensions and weight of the films $(\rho)$. This indicates that the calculation of average cell radii and cell density can be considered acceptable. On the other hand, it is important to remark that the value of $\rho^{\text {SEM }}$ is very dependent of the value of the average radii $\bar{R}$ 
Table 1. Morphological parameters of films calculated using the Image $₫$ software.

\begin{tabular}{c|cccccc}
\hline Films & $\begin{array}{c}\rho \\
\left(\mathrm{cm}^{-3}\right)\end{array}$ & $\begin{array}{c}e \\
(\mu \mathrm{m})\end{array}$ & $\begin{array}{c}\bar{R} \\
(\mu \mathrm{m})\end{array}$ & $\begin{array}{c}N_{c} \\
\left(\text { cells } \mathrm{cm}^{-3}\right)\end{array}$ & $V_{f}$ & $\begin{array}{c}\rho^{S E M} \\
(\mu m)\end{array}$ \\
\hline F_PA1 & 1.43 & 27 & $\mathrm{n} / \mathrm{a}$ & $\mathrm{n} / \mathrm{a}$ & $\mathrm{n} / \mathrm{a}$ & $\mathrm{n} / \mathrm{a}$ \\
\hline F_PA2 & 1.48 & 35 & $\mathrm{n} / \mathrm{a}$ & $\mathrm{n} / \mathrm{a}$ & $\mathrm{n} / \mathrm{a}$ & $\mathrm{n} / \mathrm{a}$ \\
\hline F_50PA1/50IL & 0.84 & 68 & $4.7 \pm 2.1$ & $8.0 \cdot 10^{9}$ & 0.29 & 0.95 \\
\hline F_50PA2/50IL & 0.50 & 37 & $3.2 \pm 1.2$ & $4.9 \cdot 10^{9}$ & 0.16 & 0.64 \\
F_50PA1/50IL-R & 0.71 & 68 & $3.8 \pm 0.4$ & $4.3 \cdot 10^{9}$ & 0.37 & 0.83 \\
F_50PA2/50IL-R & 0.39 & 45 & $3.0 \pm 0.2$ & $6.0 \cdot 10^{10}$ & 0.23 & 0.53 \\
F_(50PA1/50IL)f & 0.72 & 77 & $0.9 \pm 0.1$ & $1.9 \cdot 10^{11}$ & 0.48 & 0.78 \\
F_(50PA2/50IL)f & 0.43 & 41 & $0.7 \pm 0.1$ & $5.4 \cdot 10^{11}$ & 0.38 & 0.46 \\
\hline F_(50PA1/50IL-R)f & 0.62 & 75 & $0.9 \pm 0.1$ & $5.9 \cdot 10^{11}$ & 0.58 & 0.69 \\
F_(50PA2/50IL-R)f & 0.32 & 53 & $0.6 \pm 0.1$ & $7.4 \cdot 10^{11}$ & 0.50 & 0.44 \\
\hline F_(50PA2/50IL-R)f ${ }^{\mathrm{c}}$ & 0.31 & 53 & $3.3 \pm 1.6$ & $4.4 \cdot 10^{9}$ & 0.51 & 0.42 \\
\hline
\end{tabular}

Considering the density values, it is reduced between two and five times respect to the density of dense polyamide films. For example, density of F_(50PA2/50IL$R)_{f}$ and $F_{-}(50 P A 2 / 50 I L-R)_{f}^{c}$ is about $0.3 \mathrm{~g} \mathrm{~cm}^{-3}$, whereas the density of PA2 is close to $1.5 \mathrm{~g} \mathrm{~cm}^{-3}$, thus reaching a density reduction of around 5 times. As expected, it is also observed that removing the ionic liquids reduces the foam density from values of $0.72 \mathrm{~g} \mathrm{~cm}^{-3}$ to $0.62 \mathrm{~g} \mathrm{~cm}^{-3}$ in the case of PA1 and from 0.43 $\mathrm{g} \mathrm{cm}^{-3}$ to $0.32 \mathrm{~g} \mathrm{~cm}^{-3}$ in the case of PA2.

Films foamed with $\mathrm{ScCO}_{2}$ showed reduced average cell size compared with nonfoamed films, with cell sizes in the sub-microcellular range $\left(\bar{R}<1 \mu \mathrm{m}, \mathrm{N}_{\mathrm{c}} \approx 10^{11}\right.$ cells $\left.\mathrm{cm}^{-3}\right)$. Also, these materials showed open-cell structure with cell sizes bellow $1 \mu \mathrm{m}$, while non-foamed films had closed cells. The crosslinking, F_(50PA2/50IL$R)_{\mathrm{f}}^{\mathrm{c}}$, increase the average cell size compared to non-crosslinked foamed film, F_(50PA2/50IL-R)f, probably due to the evolution of nitrogen gas in the crosslinking process.

The key parameters of aramids are the thermal and the mechanical behavior. Thermal properties were evaluated through differential scanning calorimetry (DSC) and thermogravimetric analysis (TGA). Regarding the thermal resistance, as derived from thermogravimetric data obtained under oxidizing atmosphere (temperatures at which $5 \%$ and $10 \%$ of weight loss, $T_{5 \%}$ and $T_{10 \%}$, measured in synthetic air), the excellent performance of commercial and synthetic aramids is 
maintained, with $5 \%$ and $10 \%$ weight loss observed about 430 and $450{ }^{\circ} \mathrm{C}$ for dense and cellular materials. Glass transition temperatures were determined from DSC measurements, as exposed in Figs. S1 and S2 in Section S1.1 of the Electronic Supplementary Information (ESI). Additionally, the TGA curves can be found in Figs. S3 and S4 from Section S1.2 of the ESI.

Tensile tests data is presented in Table 2. In relation to the mechanical behavior of the cellular films, in terms of Young's moduli $(E)$ and stress at break point $\left(\sigma^{b p}\right)$, the microcellular films have lower values than the dense films. However, if density is considered and relative Young's moduli $\left(E_{r}\right)$ and stress determined $\left(\sigma^{b p} r\right)$, excellent mechanical data are obtained for the cellular materials. Thus, $E_{r}$ and $\sigma^{b p}$ values higher than 1200 and $85 \mathrm{MPa}\left(\mathrm{g} \mathrm{cm}^{-3}\right)^{-1}$, respectively, are obtained for the microcellular films. It is also observed that the treatment with $\mathrm{ScCO}_{2}$ deeply improves the mechanical performance, especially considering the $E_{r}$ values, which are increased twice respect to non-foamed films, which is probably with the higher homogeneity of the cellular morphology (Figs. 1 and 2). Also, the additional crosslinking increases drastically the value of $E_{r}$ up to $1400 \mathrm{MPa}\left(\mathrm{g} \mathrm{cm}^{-3}\right)^{-1}$, showing a better mechanical performance than dense films. Some of the obtained stress-strain curves can be found in Figs. S5-S7 in Section S1.3 of the ESI, in which, for example, the plasticization effect of the IL is clearly shown, leading to a poor mechanical behavior in films F_50PA1/50IL and F_50PA2/50IL compared to foamed films (F_50PA1/50IL-R)f and (F_50PA2/50IL-R)f (See comparative curves in Figs. S5 and S7 in the ESI). 
Table 2. Thermal and mechanical behavior of the films.

\begin{tabular}{c|cccc}
\hline Films & $\mathrm{T}_{5 \%}\left({ }^{\circ} \mathrm{C}\right)$ & $\mathrm{T}_{10 \%}\left({ }^{\circ} \mathrm{C}\right)$ & $\mathrm{E}_{\mathrm{r} \mathrm{MPa}}\left(\mathrm{g} \mathrm{cm}^{-3}\right)^{-1}$ & $\sigma_{\mathrm{r}}^{\mathrm{bp}} \mathrm{MPa}\left(\mathrm{g} \mathrm{cm}^{-3}\right)^{-1}$ \\
\hline F_PA1 & 434 & 452 & $1231 \pm 47$ & $53 \pm 4$ \\
F_PA2 & 433 & 453 & $1075 \pm 34$ & $55 \pm 5$ \\
F_50PA1/50IL-R & 431 & 453 & $649 \pm 61$ & $77 \pm 4$ \\
F_50PA2/50IL-R & 433 & 451 & $558 \pm 39$ & $87 \pm 5$ \\
F_(50PA1/50IL-R)f & 428 & 454 & $1093 \pm 61$ & $49 \pm 5$ \\
F_(50PA2/50IL-R)f & 431 & 452 & $1215 \pm 67$ & $59 \pm 6$ \\
F_(50PA2/50IL-R)fC & 404 & 428 & $1421 \pm 71$ & $65 \pm 7$
\end{tabular}

\section{Conclusions}

In summary, we have reported novel microcellular high performance aromatic polyamide materials. The microcellular materials are prepared in a green fashion using ionic liquids and supercritical $\mathrm{CO}_{2}$. We obtained homogeneous open-cell sub-micro size cellular foams, cell-size below $1 \mu \mathrm{m}$, with densities up to 5 times lower than the original material and comparable thermal and mechanical properties in terms of their outstanding behavior. The procedure can be used to prepare microcellular materials based on other high-performance condensation aromatic polymers.

\section{Acknowledgments}

The financial support provided by FEDER (Fondo Europeo de Desarrollo Regional) and the Spanish Agencia Estatal de Investigación (MAT2017-84501$\mathrm{R}$ ) is gratefully acknowledged.

\section{Funding}

This research did not receive any specific grant from funding agencies in the public, commercial, or not-for-profit sectors. 


\section{References}

[1] J.A. Reglero Ruiz, M. Trigo-López, F.C. García, J.M. García, Polymers 2017, 9, 414(1) -414(44).

[2] M. Trigo-López, J.M. García, J.A. Reglero, F.C. García, R. Ferrer, Aromatic polyamides, , pp. 151. in: H.F. Mark (Ed.), "Encyclopedia of Polymer Science and Technology", John Wiley \& Sons, Inc., New Jersey, 2018.

[3] L.J. Lee, C.C. Zeng, X. Cao, X.M. Han, J. Shen, G.J. Xu, Compos. Sci. Technol. 2005, 65, 23442363.

[4] J. Banhart, Prog. Mater. Sci. 2011, 46, 559-632.

[5] N. Mills, Polymer Foams Handbook: Engineering and Biomechanics Applications and Design, first ed. Butterworth-Heinemann, UK, 2007.

[6] S. Liu, J. Duvigneau, J. Vancso, Eur. Polym. J. 2015, 65, 33-45.

[7] B. Notario, J. Pinto, R. Verdejo, M.A. Rodríguez-Pérez, Polymer 2016, 107, 302-305.

[8] A.I. Cooper, Adv. Mater. 2003,16, 1049-1059.

[9] A.I. Cooper, J. Mater. Chem. 2000, 10, 207-234.

[10] J.L. Pablos, N. García, L. Garrido, J. Guzmán, F. Catalina, T. Corrales, P. Tiemblo, J. Membr. Sci. 2018, 545, 133-139.

[11] H. Zhang, J. Wu, J. Zhang, J. He, Macromolecules 2005, 38, 8272-8277.

[12] I. Jha, M. Bisht, P. Venkatesu, J. Phys. Chem. B 2016, 120, 5625-5633.

[13] Y. Yuan, J. Wang, N. Fu, S. Zang, Catal. Commun. 2016, 76, 46-49.

[14] J. Cota, F. Fernández Martínez, Coord. Chem. Rev. 2017, 351, 189-204.

[15] A. Wilke, J. Yuan, M. Antonietti, J. Weber, ACS Macro Lett. 2012, 1, 1028-1031.

[16] S. Siripurapu, R.J. Desimone, S.A. Khan, J.M. Spontak, Adv. Mater. 2004, 16, 989-993.

[17] S. Siripurapu, J.M. DeSimone, S.A. Khan, R.J. Spontak, Macromolecules 2005, 38, 2271-2278.

[18] M. Trigo-López, J.L. Barrio-Manso, F. Serna, F.C. García, J.M. García, Macromol. Chem. Phys. 2013, 214, 2223-2231.

[19] M. Trigo-López, J.L. Pablos, F.C. García, F. Serna, J.M. García, Polym. Chem. 2014, 52, 1469 1477.

[20] P. van de Witte, P.J. Dijkstra, J.W.A. Van den Berg, J. Feijen, J. Membrane Sci. 1996, 117, 1-31. 

Porous aromatic polyamides the easy and green way 



\section{Porous aromatic polyamides the easy and green way}

Blanca S. Pascuala, Miriam Trigo-Lópeza, José A. Reglero Ruiz ${ }^{a, *}$, Jesús L. Pablos ${ }^{b}$, Juan C. Bertolín ${ }^{c}$, César Represa ${ }^{c}$, José V. Cuevas ${ }^{a}$, Félix C. García José M. García ${ }^{a}$,

a Departamento de Química, Facultad de Ciencias, Universidad de Burgos, Plaza de Misael Bañuelos s/n, 09001 Burgos, Spain.

b Instituto de Ciencia y Tecnología de Polímeros, Consejo Superior de Investigaciones Científicas, ICTP-CSIC, Juan de la Cierva 3, 28006 Madrid, Spain.

${ }^{\mathrm{c}}$ Departamento de Ingeniería Electromecánica, Área de Tecnología Electrónica, Escuela Politécnica Superior, Universidad de Burgos, Avda. Cantabria, s/n, 09006, Burgos, Spain.

\section{Abstract}

We prepared microporous aramid films through a simple, inexpensive and green way, using ionic liquids (IL) as porosity promoters. Commercial poly ( $m$-phenylene isophthalamide) (MPIA) films with different IL proportions were prepared, and then microporous films were obtained by removing the $\mathrm{IL}$ in distilled water. Microporous films presented density values between 0.34 and $0.71 \mathrm{~g} \cdot \mathrm{cm}^{-3}$ (around five times lower to commercial MPIA), with a homogeneous and controlled cellular morphology dependent on the proportion of the IL, showing cell sizes in the microcellular range (radii between 1 and $8 \mu \mathrm{m}$ ). Thermal, mechanical and electrical properties (specifically ionic conductivity) of the aramid films were analyzed to evaluate the influence of the IL proportion. Finally, it was observed that the MPIA/IL system presented a reversible thermally induced phaseseparation process around $60^{\circ} \mathrm{C}$, which was characterized through AFM-Raman images and spectra, together with the variation of the ionic conductivity. 


\section{Introduction}

Aromatic polyamides, also known as aramids, are polymers with excellent thermal and mechanical properties, and they are considered high performance materials. These materials first appeared in the patent literature in the late 1950s and early 60 s with a number of compositions by DuPont researchers. However, the commercially important aramids nowadays is reduced to poly ( $m$-phenylene isophthalamide) (MPIA) and poly( $p$-phenylen terephthalamide) (PPTA), due to their outstanding properties combined with their low density [1]. Current research efforts are directed into the improvement of the properties of these materials [2], including lowering their weight without impairing their high-performance properties, which is important for applications related to the aeronautic and automotive industries and in human protection clothing. The preparation of polymers with cellular structure is a means for lowering the weight of materials. However, a vast control of their morphology is needed to produce these materials at an industrial scale, and thus, research efforts have been focused to reach that goal.

In our previous work [3], we reported on the development of foamed aramids using a non-volatile ionic liquid (1-allyl-3-methylimidazolium chloride) and supercritical $\mathrm{CO}_{2}\left(\mathrm{ScCO}_{2}\right)$ for the first time. We successfully lowered the density

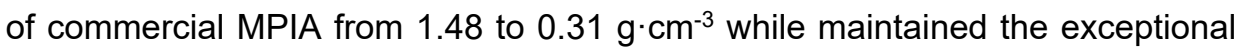
mechanical and thermal properties. $\mathrm{ScCO}_{2}$ foaming process is widely employed to obtain micro and nanocellular polymers, due to the low critical conditions of $\mathrm{ScCO}_{2}\left(31.1^{\circ} \mathrm{C}\right.$ and 73.8 bar), which offers many advantageous properties, like a tunable solvent power, plasticization of glassy polymers and higher diffusion rates $[4,5]$. On the contrary, the production of cellular polymers using $\mathrm{ScCO}_{2}$ requires a specific experimental set-up, with a high-pressure reactor, and also high processing times (up to several hours), depending on the $\mathrm{CO}_{2}$ affinity of the polymer.

We decided to explore the possibility of using ionic liquids due to their plasticization effect combined to their good affinity for the $\mathrm{CO}_{2}$, two of the most 
important properties of these compounds. Traditionally, ionic liquids (IL) have been employed as green replacements for traditional volatile organic solvents as they are considered environmentally friendly and easily recyclable [6]. As a result, many examples can be found in aramids literature concerning the use of IL in many different applications, such as compatibilizers in composites [7], as solvent for dry-jet-wet-electrospinning [8], or as solvents in the synthesis of PPTA or solution of its oligomers $[9,10]$. In this sense, it is important to consider that most of the ionic liquids are hygroscopic [11,12], and they absorb water at different extents either from wet surfaces or from the air [13-17]. Concerning the specific relation between ionic liquids and aramids, we only found a work reported in 2007 about the use of different ionic liquids in the production of poly $(m$-phenylene isophtalamide) fibers [18].

Although our initial goal was to evaluate the influence of the $\mathrm{IL}$ in the $\mathrm{ScCO}_{2}$ foaming process, we surprisingly observed that only the removal of this specific $\mathrm{IL}$ to the aramid solution in dimethylacetamide (DMAc) during the preparation of cast films led to the development of a homogeneous microporous structure. In fact, when IL was removed, aramid films showed a high opacity, a classical effect of foamed materials, which is related to the diffraction of the light inside the microporous structure. The porosity could be explained through a thermally induced phase separation process due to the presence of the IL, a phenomenon described previously in the literature $[19,20]$, but which has not been reported as an alternative fabrication process of porous aramids. For this reason, we started this novel research line, which is presented in this work, focusing our efforts in the use of ILs to prepare microcellular aramids with controlled structure, avoiding the whole $\mathrm{ScCO}_{2}$ foaming process, thus simplifying as much as possible the obtention of microporous aramid films.

Bearing these ideas in mind, we easily prepared five porous aramid films containing different proportions of ILs and a commercial dense MPIA film for comparison purpose, and we studied them in terms of cellular structure, density, mechanical, thermal and ionic conductivity measurements, evaluating the relation between the proportion of the IL added and the final characteristics of the 
microporous aramid films.

\section{Experimental part}

\subsection{Materials and measurements}

1-allyl-3-methylimidazolium chloride ( $\geq 97 \%$ ) was used as ionic liquid (SigmaAldrich, used as received). N,N-dimethylacetamide (DMAc, Aldrich, >99\%) was vacuum-distilled over phosphorous pentoxide twice and then stored over $4 \AA$ molecular sieves. Isophthalic dichloride (IPC) (Aldrich, >99 \%) was purified by double crystallization from dry heptane. $m$-Phenylenediamine (MPD) is commercially available (Aldrich, $>99 \%$ ) and was purified by double vacuum sublimation.

The number average molecular weight $\left(M_{\mathrm{w}}\right)$ of the polyamides was measured using the Mark-Houwink equation, $[\eta]=k M_{\mathrm{w}}{ }^{\alpha}$, where the values of the constant $k$ and $\alpha$ for polymer solutions in $96 \%$ sulfuric acid are $0.00013 \mathrm{dL} \mathrm{g}^{-1}$ and 0.84 , respectively. The intrinsic viscosity $[\eta]$ was calculated by measuring the inherent viscosities, $\eta_{\text {inh, }}$ of the aramid at different polymer concentrations $(0.5,0.3,0.1$ and $0.05 \mathrm{~g} \cdot \mathrm{dL}^{-1}$ ) with a Ubbelohde viscometer using sulfuric acid (96\%) as the solvent at $30^{\circ} \mathrm{C} \pm 0.1^{\circ} \mathrm{C}$ and extrapolating to zero concentration.

Differential Scanning Calorimetry (DSC) measurements of the polyamide films were carried out in a DSC Q200 TA Instruments equipment. The analysis of the glass transition temperatures was carried out following a four-cycle procedure. First, after $5 \mathrm{~min}$ of stabilization at $30{ }^{\circ} \mathrm{C}$, films were heated up to $350{ }^{\circ} \mathrm{C}$ at 20 ${ }^{\circ} \mathrm{C} / \mathrm{min}$. Then, after $5 \mathrm{~min}$ of stabilization at $350^{\circ} \mathrm{C}$, films were cooled down to RT at the same rate. Third, a second heating cycle was performed following the same conditions of the first cycle, concluding with a final cycle to cool down the samples to $\mathrm{RT}$ at $20^{\circ} \mathrm{C} / \mathrm{min}$.

The AFM-RAMAN images and spectra were taken using a confocal AFM-RAMAN model Alpha300R - Alpha300A AFM Witec, using a laser wavelength of $532 \mathrm{~nm}$ with $2 \mathrm{~mW}$, at 100X. The area of the image was fixed at $5 \times 5 \mu \mathrm{m}^{2}$. Images and spectra were taken at RT and $70^{\circ} \mathrm{C}$. On the other hand, video images were 
recorded with the same equipment, at $10 \mathrm{X}$, from $\mathrm{RT}$ to $70^{\circ} \mathrm{C}$, at a heating rate of $10{ }^{\circ} \mathrm{C} \cdot \mathrm{min}^{-1}$, to observe the formation of the single MPIA-IL phase.

The thermogravimetric analysis data were recorded on a TA Instrument Q50 TGA analyzer. Films were first dried in vacuum overnight at $40{ }^{\circ} \mathrm{C}$, and then TGA tests were performed under $\mathrm{O}_{2}$ atmosphere using the next procedure: First, films were heated from $\mathrm{RT}$ to $100{ }^{\circ} \mathrm{C}$ at $10^{\circ} \mathrm{C} \cdot \mathrm{min}^{-1}$, and then kept during $5 \mathrm{~min}$ to eliminate the moisture content. Finally, TGA analysis was completed by heating up to $800{ }^{\circ} \mathrm{C}$ at $10^{\circ} \mathrm{C} \cdot \mathrm{min}^{-1}$.

To determine the mechanical properties $5 \times 40 \mathrm{~mm}^{2}$ strips were cut from the polyamide membrane and tensile tests were performed on a SHIMADZU EZ Test Compact Table-Top Universal Tester. Mechanical clamps were used and an extension rate of $5 \mathrm{~mm} \cdot \mathrm{min}^{-1}$ was applied using a gauge length of $9.44 \mathrm{~mm}$. At least 5 samples were tested for each film, and the data was then averaged.

Cellular structural determination of the microcellular films was carried out in a scanning electron microscopy model JEOL JSM-6460LV. Films were frozen in liquid nitrogen, fractured and gold coated in vacuum to assure the electrical conductivity of the films. Cellular structural characterization determining the average bubble radius and average cell density from SEM images, measured using the Image ${ }^{\circledR}$ software, counting the number of bubbles in each image $n_{i}$ and its radius $R_{i}$. The average radius $\bar{R}$ is calculated from Eq. (1):

$$
\bar{R}=\frac{\sum_{i=1}^{N} n_{i} R_{i}}{\sum_{i=1}^{N} n_{i}}
$$

where $N$ represents the bubble count. Three different SEM images were analyzed from each material, averaging the data. The estimation of the cell density $N_{c}$ was calculated using the Kumar's approximation, according to Eq. (2):

$$
N_{c}=\left(\frac{n}{A}\right)^{3 / 2}
$$

where $n$ is the number of cells in the image and $A$ is the area of the image. 
Taking into account the average radius value and cell density, the gas volume fraction $V_{f}$ was obtained using Eq. (3):

$$
V_{f}=\frac{\pi \bar{d}^{3} N_{c}}{6}
$$

where $\bar{d}$ is the average diameter. Then, gas volume fraction $V_{f}$ and foam density $\rho^{S E M}$ are related throughout Eq. (4), in which $\rho_{s}$ is the solid material density:

$$
V_{f}=1-\frac{\rho^{S E M}}{\rho_{s}}
$$

The theoretical calculations were carried out using the quantum chemical software ORCA 4.0.1.2.1, using the PBEh-3c method [21]. This method, that shows excellent performance for non-covalent interaction energies in small and large complexes, includes geometrical counterpoise correction, gCP [22], for removing the BSSE (Basis Set Superposition Error), and the atom-pairwise dispersion correction with the Becke-Johnson damping scheme (D3BJ) [23,24]. The basis set used is def2-mSVP [25] in combination with auxiliary basis set RI$J$ [26]. Def2-mSVP is defined as the Valence double-zeta basis set of the Karlsruhe group with polarization function, whereas RI-J means the Resolution of Identity approximation (also called Density Fitting), applied to Coulomb Integrals $(\mathrm{J})$. In this case, we are using the auxiliary basis def2/J. The Cartesian coordinates of the optimized geometries can be found in the ESI.

\subsection{Preparation and testing of polyamide films}

Aromatic polyamide MPIA was synthetized following the procedure described in our previous work by the conventional solution low temperature polycondensation method from IPC and MPD $[27,28]$. Thus, the polycondensation was carried out in a three necked flask fitted with a mechanical stirrer and nitrogen inlet. It was then charged with $39.40 \mathrm{~mL}$ of DMAc under a blanket of nitrogen at rt and $4.26 \mathrm{~g}$ (39.40 mmol) of MPD were added. After the solution of the diamine at rt under stirring, the system was then cooled to $0^{\circ} \mathrm{C}$, and $8.00 \mathrm{~g}(39.40 \mathrm{mmol})$ of IPC was 
added portion wise over $5 \mathrm{~min}$ (about four amounts). The reaction conditions were maintained for $30 \mathrm{~min}$, and then the cooling was discontinued, and the reaction proceed for additional $3.5 \mathrm{~h}$. The solution was slowly poured into distilled water, giving rise to a fibrous and swollen precipitate that was filtered, washed thoroughly with water and acetone. The yield was quantitative.

To prepare the porous aramid films with ILs a simple method was followed: $0.21 \mathrm{~g}$ of MPIA was dissolved portion wise in $3 \mathrm{~mL}$ of DMAc and stirred until full dissolution is observed. The corresponding amount of the IL was added then to the solution and stirred for an additional hour. After that, the mixture was filtered off and cast in a glass placed inside an air-circulating oven at $60{ }^{\circ} \mathrm{C}$ for $16 \mathrm{~h}$. To remove the ILs, the films were washed by immersing them in distilled water for $24 \mathrm{~h}$, replacing every 8 hours the distilled water solution to assure the complete removal of the IL. The tensile tests and the scanning electron microscopy images were obtained before and after removal the IL, whereas the thermal tests (TGA and DSC) were performed only after removing the IL. Finally, ionic resistivity tests were carried out in films containing the ILs.

\section{Results and discussion}

\subsection{Preparation of aromatic polyamides}

Aramids are high-performance polymers that are usually prepared in the lab using high and low temperature solution methods. The former from direct condensation of aromatic diacids and aromatic diamines, and the later by condensation of aromatic diacid dichlorides and aromatic polyamides. Commercially, these materials are synthesized following the low temperature methodology and processed into fibers (pulp, staple fibers, and continuous multifilament yarns) by dry-spinning, wet-spinning, and dry-jet wet-spinning [1]. In our case, we have prepared MPIA in solution upon polymerization IPC and MPDA $\left(\eta_{\text {inh }}=1.12 \mathrm{dL} \mathrm{g}^{-1}\right.$; $\left.[\eta]=1.35 \mathrm{dL} \mathrm{g}^{-1} ; M_{\mathrm{w}}=6.0 \times 10^{4}\right)$.

For comparative studies we prepared a dense aromatic polyamide film by casting, 
called from now on dense MPIA, with a conventional density for aramids (1.43 $\left.\mathrm{g} \cdot \mathrm{cm}^{-3}\right)$. Then, another five aramid films were prepared having $50,60,75,80$ and $90 \%$ wt. of the IL 1-allyl-3-methylimidazolium chloride. It is important to remark that in a previous study [3], lower percentages of IL were loaded to the polyamide, but no porous structure was observed.

\subsection{Density and morphological parameters}

After, we removed chemically the IL by immersion of the aramid films in distilled water for $24 \mathrm{~h}$. We denoted these films as 50MPIA/50IL-R, 40MPIA/60IL-R, 25MPIA/75IL-R, 20MPIA/80IL-R and 10MPIA/90IL-R. Then, the porous structure was originated due to the elimination of the IL in distilled water over $24 \mathrm{~h}$, causing the development of the porosity inside the polyamide film. Fig. S1 in the Electronic Supplementary Information (ESI) presents two photographs of the film containing $50 \%$ of IL, before and after the IL removal process in distilled water during $24 \mathrm{~h}$, in which an increase of the opacity of the film is evidenced, due to the formation of the microporous structure after the removal of the IL. To assure that all the DMAc and IL were completely removed after evaporating the solvent at $60^{\circ} \mathrm{C}$ during $16 \mathrm{~h}$ and lately placing the film in distilled water during $24 \mathrm{~h},{ }^{1} \mathrm{H}-\mathrm{RMN}$ of the films were carried out using DMSO- $d_{6}$ as solvent. Fig. S2 in the ESI presents, as an example, the ${ }^{1} \mathrm{H}-\mathrm{RMN}$ spectrum of the 40MPIA/60IL-R film, in which no traces of DMAc or IL are observed. It is important to remark that the results were similar in all the films.

In Table 1 we present the density of the microporous aramid films and the density of the dense MPIA film, together with the morphological parameters. In all the cases density values are reduced compared to the dense film MPIA. Microporous aramid films present density values between 0.34 and $0.71 \mathrm{~g} \cdot \mathrm{cm}^{-3}$, thus reaching a reduction between 2- and 4.5-times respect to the density of the dense MPIA. Concerning the morphology, all films present a well-defined microporous structure, with cell sizes between 1 and $8 \mu \mathrm{m}$, and cell densities in the range of $10^{8}-10^{11}$ cells $\cdot \mathrm{cm}^{-3}$. In addition, the film density was also estimated from the average cell size and cell density measurements $\left(\rho^{\text {SEM }}\right)$, obtaining values which 
are comparable to the volumetric density, obtained directly from weight and geometrical dimensions, then validating the morphological calculation procedure.

Table 1. Morphological parameters of microporous aramid films. ( $\rho$ is the foam density measured from dimensions and weight of the film and $e$ is the film thickness. Image ${ }^{\circledR}$ software was employed to determine the average cell radius $\bar{R}$ the cell density $\mathrm{N}_{\mathrm{c}}$, the gas volume fraction $\mathrm{V}_{\mathrm{f}}$ and the foam density from morphological parameters, $\rho^{\mathrm{SEM}}$ ).

\begin{tabular}{c|cccccc}
\hline $\begin{array}{c}\text { Aramid } \\
\text { film }\end{array}$ & $\begin{array}{c}\boldsymbol{\rho} \\
\left(\boldsymbol{g} \cdot \boldsymbol{c m}^{3}\right)\end{array}$ & $\begin{array}{c}\boldsymbol{e} \\
(\boldsymbol{\mu m})\end{array}$ & $\begin{array}{c}\overline{\boldsymbol{R}} \\
(\boldsymbol{\mu m})\end{array}$ & $\begin{array}{c}\boldsymbol{N}_{\boldsymbol{c}} \\
(\mathbf{c e l l s} \\
\left.\boldsymbol{c m}^{-3}\right)\end{array}$ & $\boldsymbol{V}_{\boldsymbol{f}}$ & $\begin{array}{c}\boldsymbol{\rho}^{\text {SEM }} \\
\left(\boldsymbol{g} \cdot \boldsymbol{c m}^{-3}\right)\end{array}$ \\
\hline $\begin{array}{c}\text { Dense } \\
\text { MPIA }\end{array}$ & 1.43 & 27 & $\mathrm{n} / \mathrm{a}$ & $\mathrm{n} / \mathrm{a}$ & $\mathrm{n} / \mathrm{a}$ & $\mathrm{n} / \mathrm{a}$ \\
$\begin{array}{c}\text { 50MPIA/ } \\
\text { 50IL-R }\end{array}$ & 0.71 & 66 & $1.64 \pm 0.08$ & $3.52 \cdot 10^{11}$ & 0.47 & 0.75 \\
$\begin{array}{c}\text { 40MPIA/ } \\
\text { 60IL-R }\end{array}$ & 0.57 & 82 & $3.21 \pm 0.23$ & $4.41 \cdot 10^{10}$ & 0.57 & 0.61 \\
$\begin{array}{c}\text { 25MPIA/ } \\
\text { 75IL-R }\end{array}$ & 0.38 & 171 & $8.32 \pm 4.16$ & $7.15 \cdot 10^{8}$ & 0.69 & 0.43 \\
$\begin{array}{c}\text { 20MPIA/ } \\
\text { 80IL-R }\end{array}$ & 0.40 & 181 & $1.34 \pm 0.18$ & $1.37 \cdot 10^{11}$ & 0.70 & 0.42 \\
$\begin{array}{c}\text { 10MPIA/ } \\
\text { 90IL-R }\end{array}$ & 0.34 & 269 & $\mathrm{n} / \mathrm{a}$ & $\mathrm{n} / \mathrm{a}$ & $\mathrm{n} / \mathrm{a}$ & $\mathrm{n} / \mathrm{a}$
\end{tabular}

SEM micrographs of the cut section of the microporous aramid films were taken following the preparation procedure presented in Section 2.1. Fig. 1 presents the micrographs taken on the cut section of the aramid films after the removal of the IL. On the other hand, different SEM images were taken of the surface of the aramid films, showing in all the cases a solid outer skin without any porosity (See Fig. S3 of the ESI). 

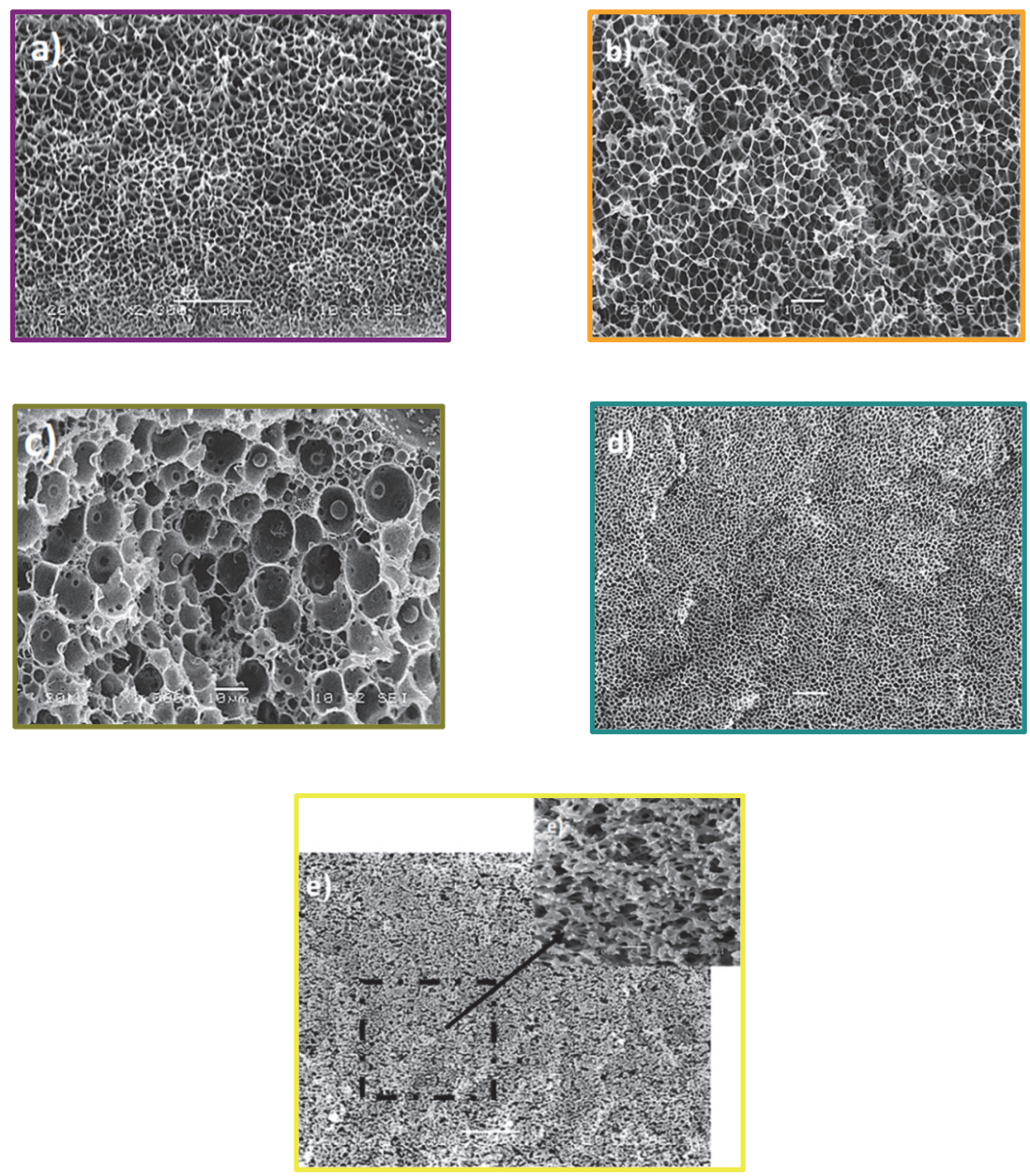

Fig. 1. SEM micrographs of the microporous aramid films. All pictures taken at 1000x: a) $50 \mathrm{MPIA} / 50 \mathrm{IL}-\mathrm{R}$; b) $40 \mathrm{MPIA} / 60 \mathrm{IL}-\mathrm{R}$; c) $25 \mathrm{MPIA} / 75 \mathrm{IL}-\mathrm{R}$; d) $20 \mathrm{MPIA} / 80 \mathrm{IL}-\mathrm{R}$; e) $10 \mathrm{MPIA} / 90 \mathrm{IL}-\mathrm{R}$ (magnification taken at $3000 \mathrm{x}$ ).

Having a look at the SEM micrographs in Fig. 1, some specific conclusions can be extracted. Concerning the morphology of the microporous aramids, all the films prepared showed a very homogeneous structure with closed cells. Only the aramid film with $90 \%$ wt. of IL shows a very different morphology, with connected microchannels of a few microns width, in which the calculation of the different morphological parameters is not simple (see Fig. 1e). This is probably due to the 
high proportion of the $\mathrm{IL}$ employed. The proportion of the $\mathrm{IL}$ is also crucial to control the average cell size. For example, there is a direct relation between the increase of cell size and the proportion of IL up to values of $75 \%$ wt., but on the other hand, adding $80 \%$ wt. of IL reduces drastically the cell size, then obtaining closed-cell microporous aramids with excellent homogeneity and cell sizes around $1 \mu \mathrm{m}$ (see Fig. 1d). These structures are specially interesting when compared to films with $75 \%$ wt. of IL, which, although they are fabricated with almost the same quantity of IL, present a very inhomogeneous structure, with bimodal morphologies and also fractured cell walls (See Fig. 1c). Several films were fabricated using the $75 \%$ wt. of IL, obtaining the same inhomogeneous morphologies in all the cases, then confirming the very different behavior of this composition.

\subsection{Thermally induced phase-separation process}

Different literature works can be found in which ILs are used to obtain polymeric porous materials using several mechanisms. In this sense, a recent review analyzing the preparation of porous membranes for gas separation applications using ILs has been presented by Wang et al. [20] in 2016. Another interesting work was presented recently by Täuber et al. [29] in which porous polymer membranes were obtained from water soluble ionic liquids, via electrostatic complexation. Another fabrication route, based on the phase inversion process promoted by the ILs has been reported by Lakshmi et al. [30] as a very effective fabrication process of porous polyethersulfone membranes, using 1-butyl-3methylimidazolium hexafluorophosphate as IL.

However, considering the specific fabrication of polymeric porous membranes using ILs as thermal phase-separation inducers, only a few works can be found in the literature. A classical review concerning the physic-chemical aspects of the phase-separation process in polymer solutions to produce porous membranes was presented by Van de Witte et al. [31] in 1996. More recently, different authors analyze the phase-separation process using ILs to obtain porous polymeric 
membranes. For example, Liu et al. [32] presented the preparation of porous poly(vinylidene fluoride) membranes using 1-butyl-2,3-dimethylimidazolium tetrafluoroborate as IL, and Chen et al. [33] showed the fabrication of porous poly(ethylene oxide) membranes employing 1-ethyl-3-methylimidazolium tetrafluoroborate as IL. Concerning the specific fabrication of porous aramid membranes, there is a lack of scientific literature up to date, due to the intrinsic difficulties associated to the production of these materials, then conferring to our work an excellent starting point to obtain porous aramid membranes.

As it has been commented in the introduction section, in our case, during the film preparation we observed that samples were transparent at $60^{\circ} \mathrm{C}$ when they were extracted from the oven in which DMAc was evaporated, but after a few minutes at $\mathrm{RT}$, the films turned completely opaque. We believe that the polyamide and the ionic liquid system (MPIA-IL) at $60{ }^{\circ} \mathrm{C}$ were completely mixed in a single phase, and then cooling down to RT caused the formation of a two-phase material via the phase-separation mechanism, originating the opacity. The phaseseparation process is reversible, and several heating-cooling cycles has been carried out changing from opaque to transparent samples when MPIA-IL phases were mixed or segregated, respectively.

The effect of the phase-separation process in the aramid films properties was investigated from different and complementary perspectives. In this section, we will focus our analysis in the AFM-Raman technique to study the IL distribution in the MPIA, and its relation to the microporous structure in the aramid film after the IL removal, following the protocol presented in Section 2.1. The Raman analysis has been also previously employed by Lakshmi et al. [30], to analyze the distribution of 1-butyl-3-methylimidazolium hexafluorophosphate in polyethersulfone membranes. However, our objective was not only to analyze the distribution of the IL in the MPIA, but also to determine the relation between the IL presence and the microporous structure of the aramid film. The 50MPIA/50IL film was also selected as example, collecting two different Raman images and spectra (one at RT, in which both phases are clearly visible, and another at $70{ }^{\circ} \mathrm{C}$, when a single-phase PA-IL is formed). Fig. 2 presents the obtained results. 
The phase transition process is clearly demonstrated from the AFM Raman images and spectra taken at different temperatures. Fig. 2a presents the Raman mapping taken from the 50MPIA/50IL at RT, in which both phases are separated, presenting each of the phases the Raman spectra of pure IL and pure MPIA. Heating the sample up to $70^{\circ} \mathrm{C}$ leads to the formation of a single MPIA/IL phase, which is reflected in Fig. 2b, in which the Raman mapping shows a homogeneous aspect, with a unique Raman spectrum corresponding to the mixed MPIA/IL phase. The formation of the single-phase is captured in Fig. S4 of the ESI, which shows several optical photographs of the 50MPIA/50IL film taken at different temperatures.

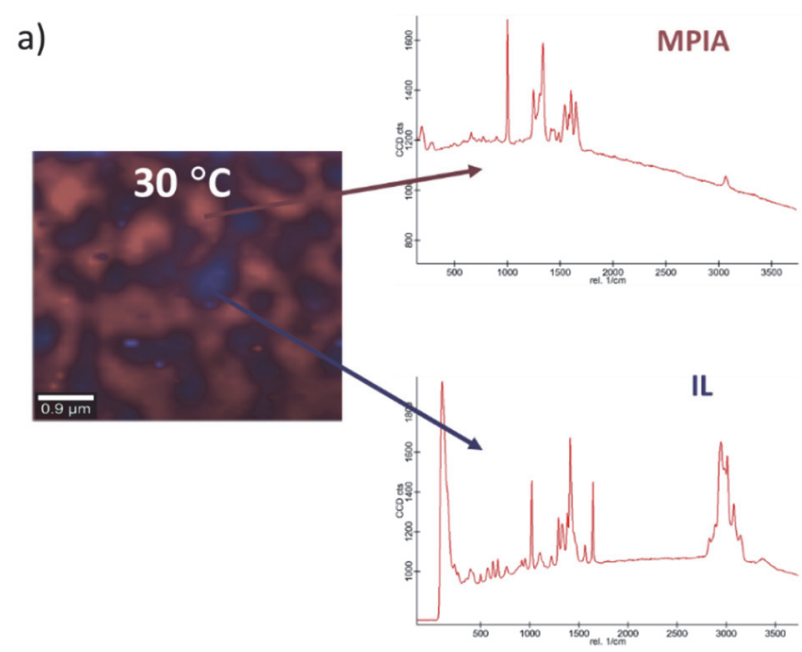

b)

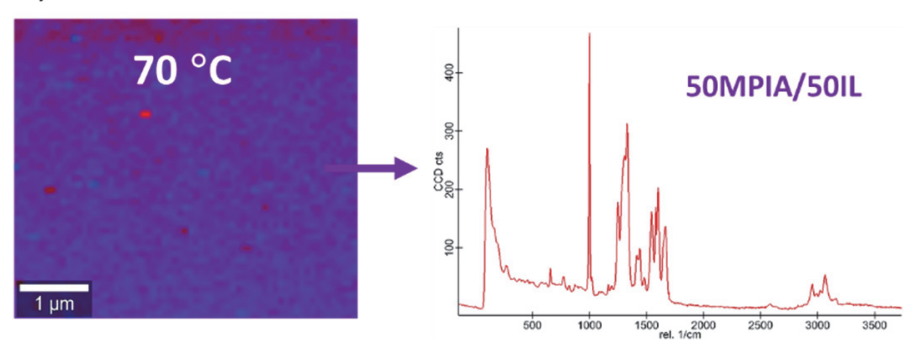

Fig. 2. AFM Raman images and spectra of the 50MPIA/50IL film at different temperatures. a) $30^{\circ} \mathrm{C}$; b) $70^{\circ} \mathrm{C}$. 
As stated before, the formation of the microporous structure seems to be related to the removal of the IL, which could originate the porosity. Fig. S5 of the ESI presents the AFM Raman mapping taken at $30^{\circ} \mathrm{C}$ of the $50 \mathrm{MPIA} / 50 \mathrm{IL}$ film together with a SEM micrograph of the microporous 50MPIA/50IL-R after the IL removal, in which it is demonstrated that the IL distribution and the resultant porosity are directly related.

In order to get insight into the interaction of IL with the polymer, DFT calculations were performed (see experimental part for details). The structure of a polyamide dimer (mimicking the polymer structure) interacting with two ionic pairs of the IL, two interacting dimers, and an ionic liquid species were optimized. The two dimers display interactions of hydrogen bond and $\pi$-stacking between the two chains (see Fig. S6 of the ESI). The optimization of the dimer interacting with two ionic pairs of the ionic liquid displays how the chloride anions orientate towards the $\mathrm{N}-\mathrm{H}$ bonds of the polyamide whereas the cationic 1-ethyl-3methylimidazolium cation (IL) orientates towards the carboxylic oxygen of the polyamide (see Fig. S7 and S8 in the ESI).

The calculated free energy at $60{ }^{\circ} \mathrm{C}$ for the reaction in which the two dimers interacts with the ionic liquid [(polyamide $)_{2}+4 \mathrm{IL} \rightarrow 2$ polyamide/(IL) $)_{2}$ yields a value of $-41.03 \mathrm{kcal} \cdot \mathrm{mol}^{-1}$, indicating that the interaction is thermodynamically favorable, in agreement with experimental observation (the cartesian coordinates of the modelized structures are shown in the ESI, Tables S1 - S3).

\subsection{Thermal and mechanical properties}

The key parameters of the aramids that makes them high performance materials are essentially the thermal and the mechanical behavior. The thermal behavior of the microporous films after the removal of the IL was evaluated in terms of $5 \%$ and $10 \%$ of weight loss through a thermogravimetric analysis (TGA), and the glass transition temperature $\left(T_{g}\right)$ was determined with differential scanning calorimetry (DSC).

Regarding the thermal resistance, the excellent performance of the commercial 
aromatic polyamides is practically maintained, with $5 \%$ and $10 \%$ weight loss around $430{ }^{\circ} \mathrm{C}$ and $460{ }^{\circ} \mathrm{C}$ (values of the dense MPIA film are $453^{\circ} \mathrm{C}$ and $477^{\circ} \mathrm{C}$ ), regardless of the amount of ionic liquids, thus indicating that the removal of the ILs was practically completed. We only observed a small reduction of the thermal stability in film 25MPIA/75IL-R, (around $15{ }^{\circ} \mathrm{C}$ in $T_{5 \%}$ and $T_{10 \%}$ values), that could be related to the inhomogeneous microporous structure and the presence of fractured walls, as it was observed in the SEM micrograph presented in Fig. 1c. Thus, it seems to be an influence of the microporous structure in the thermal stability of this aramid film, probably due to the different oxygen content trapped inside the cells, which can affect to the thermal resistance. Thermal properties are presented in Table 2. On the other hand, $T_{g}$ values of the different films were maintained compared to the commercial MPIA, around $275^{\circ} \mathrm{C}$. TGA and DSC curves of all aramid films can be found in Fig. S9 and S10 of the ESI.

Table 2. Thermal properties of aramid films. ( $T_{5 \%}$ and $T_{10 \%}$ are the temperatures where 5 and $10 \%$ wt. of mass loss, and $\mathrm{Tg}$ is the glass transition temperature)

\begin{tabular}{l|lll}
\hline Aramid Film & $\mathbf{T}_{\mathbf{5}}\left({ }^{\circ} \mathbf{C}\right)$ & $\mathbf{T}_{\mathbf{1 0}}\left({ }^{\circ} \mathbf{C}\right)$ & $\mathbf{T g}\left({ }^{\circ} \mathbf{C}\right)$ \\
\hline Dense MPIA & 453 & 477 & 273 \\
50MPIA/50IL-R & 438 & 462 & 271 \\
40MPIA/60IL-R & 438 & 465 & 275 \\
25MPIA/75IL-R & 423 & 438 & 276 \\
20MPIA/80IL-R & 433 & 466 & 275 \\
10MPIA/90IL-R & 431 & 463 & 276
\end{tabular}

The mechanical properties of the microporous aramid films were tested concerning the relative Young's moduli $\left(E_{r}\right)$ and relative stress at break point $\left(\sigma^{b p} r\right)$, (ratio between measured values and film density, extracted from the data in Table 1). Relative values were employed in order to compare effectively the mechanical behavior of the microporous films and dense films obtained from commercial MPIA. All the stress-strain curves obtained in the tensile tests can be found in Fig. S11 of the ESI, whereas the mechanical data is presented in Table 3. (Mechanical data of dense MPIA film was extracted from our previous work [3].) 
Table 3. Mechanical properties of aramid films obtained from the tensile tests. ( $E_{r}$ is the relative Young's modulus and $\sigma_{r}^{b p}$ is the relative stress at break point).

\begin{tabular}{c|cc}
\hline Aramid Film & $E_{r}\left(\mathbf{M P a} \cdot\left(\mathbf{g} \cdot \mathbf{c m}^{-3}\right)^{-1}\right)$ & $\boldsymbol{\sigma}_{\boldsymbol{r}}^{\boldsymbol{b} \boldsymbol{p}}\left(\mathbf{M P a} \cdot\left(\mathbf{g} \cdot \mathbf{c m}^{-3}\right)^{-\mathbf{1}}\right)$ \\
\hline Dense MPIA & $1231 \pm 47$ & $53 \pm 4$ \\
50MPIA/50IL-R & $1013 \pm 61$ & $16 \pm 4$ \\
40MPIA/60IL-R & $922 \pm 45$ & $15 \pm 1$ \\
25MPIA/75IL-R & $490 \pm 32$ & $18 \pm 3$ \\
20MPIA/80IL-R & $1114 \pm 59$ & $15 \pm 5$ \\
10MPIA/90IL-R & $320 \pm 23$ & $12 \pm 4$
\end{tabular}

Data presented in Table 3 indicates a direct correlation between the microporous structure of the films and the relative mechanical values measured. As expected, the dense aramid film presents the best mechanical performance, with the highest values of both Young's modulus and stress at break relative values (1231 and $53 \mathrm{MPa} \cdot\left(\mathrm{g} \cdot \mathrm{cm}^{-3}\right)^{-1}$, respectively). When microporous structure appears, there is a general reduction of the values of stress at break around four times, down to values between 12 and $18 \mathrm{MPa} \cdot\left(\mathrm{g} \cdot \mathrm{cm}^{-3}\right)^{-1}$, then showing a ductile behavior compared to dense aramid film. However, the Young's modulus parameter does not follow the expected behavior, presenting some remarkable results, with a clear influence of the cell size and the homogeneity of the microporous structure. For example, in the case of the film 20MPIA/80IL-R, the relative Young's modulus lies around the value measured for the dense aramid film (1114 and 1231 MPa $\left(\mathrm{g} \cdot \mathrm{cm}^{-3}\right)^{-1}$, respectively, indicating that it is possible to reduce the aramid's density from 1.43 to $0.40 \mathrm{~g} \cdot \mathrm{cm}^{-3}$ without losing mechanical resistance, then pointing out the role of the microporous structure created by simply eliminating the IL. On the contrary, we observed that the aramid microporous film with $75 \%$ wt. of IL (25MPIA/75IL-R) which presented a very inhomogeneous porous structure, with larger cell sizes and broken cell walls (see Fig. 1c), shows a poor mechanical resistance, with values around $490 \mathrm{MPa} \cdot\left(\mathrm{g} \cdot \mathrm{cm}^{-3}\right)^{-1}$. Both results indicate the influence of the microporous structure in the mechanical behavior of the aramid films, then giving the possibility of tuning easily their mechanical properties in terms of the initial proportion of IL employed. 


\subsection{Ionic conductivity}

Ionic liquids are usually employed in the design of solid electrolytes with electrochemical characteristics comparable to those of liquid ones, in order to obtain self-standing materials combining high ionic diffusivity (and hence high ionic conductivity) and dimensional stability. For these reasons, in the last years the ideal candidates have been polymer-based materials in which the ionic diffusivity is enhanced with the presence of different ionic liquids, such as 1-ethyl3-methylimidazolium bis(fluorosulfonyl)imide, 1-butyl-1-methylpyrrolidinium bis(fluorosulfonyl)imide or bis(trifluoromethane)sulfonimide lithium salt [34,35].

Polyamides are essentially non-conductive materials, and they must be combined with different charges to obtain conducting materials with excellent mechanical and thermal properties [36]. In our case, we decided to analyze the ionic conductivity of the polyamide films using a four-point probe already employed in our group to determine the electrical properties of porous aramid films [37]. Films were cut in samples of $40 \times 40 \mathrm{~mm}^{2}$ and fixed to a glass plate. Then, the four-point probe was put in contact with the surface of the samples, obtaining the ionic resistivity. Five different measurements were carried out in each sample, to also observe the homogeneity of the surface, then averaging the results. Fig. 3 presents the ionic resistivity ( $\rho$ ) obtained for each sample as a function of the proportion of ionic liquid.

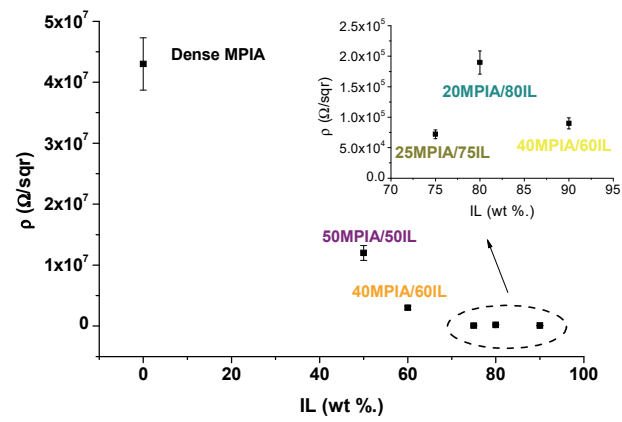

Fig. 3. Ionic resistivity of porous aramids as a function of the quantity of ionic liquid. 
The influence of the $\mathrm{IL}$ in the ionic transport properties of the aramid films is clearly observed in Fig. 3. As expected, dense MPIA film shows a high ionic resistivity value due to the isolating behavior of the neat polymer. Increasing the quantity of the IL results in a decrease of the ionic resistivity, conferring a conductive behavior to the aramid films. Adding $50 \%$ wt. of IL reduces four times the ionic resistivity compared to dense MPIA film (from $4 \cdot 10^{7}$ to $1 \cdot 10^{7} \Omega / s q r$ ).

The reduction in the ionic resistivity is proportional to the quantity of IL, and, for example, aramid film with $90 \% \mathrm{wt}$. of IL presents an ionic resistivity value around $10^{5} \Omega / \mathrm{sqr}$, then two magnitude orders lower than the dense MPIA. However, it is important to remark that measurement in aramid films with $90 \%$ wt. were especially problematic, due to the great flexibility of the films the high quantity of $\mathrm{IL}$, then hindering the contact between the tips of the probe and the surface of the material.

Additionally, aramid films with $75 \%$ wt. do not seem to follow the expected correlation, presenting a very low value of the ionic resistivity $\left(\approx 5.10^{4} \Omega / \mathrm{sqr}\right)$, compared to films with $80 \%$ wt $\left(\approx 2 \cdot 10^{5} \Omega / \mathrm{sqr}\right)$. We already observed that this proportion of IL resulted in a very inhomogeneous cellular morphology (see Fig. 1c), reflected also in the poor tensile properties obtained (see Fig. S11 of the ESI).

Thus, it seems that the proportion of the IL plays a key role in the resulting mechanical and ionic transport properties, demonstrating a direct relation microstructure-properties and opening the possibility of a controlled, simple and inexpensive fabrication of conductive aramid films with excellent mechanical properties.

To conclude, we also investigated the phase-separation process reversibility measuring the ionic resistivity during a heating-cooling cycle, using a controlledtemperature furnace. 50MPIA/50IL aramid sample was heated from RT to $80{ }^{\circ} \mathrm{C}$ and then cooling down to RT registering the ionic resistivity evolution.

Results are presented in Fig. 4. It can be observed that the ionic resistivity drops 
from $9 \cdot 10^{6} \Omega /$ sqr to $2 \cdot 10^{6} \Omega$ sqr due to the formation of the single MPIA-IL phase between 50 and $70{ }^{\circ} \mathrm{C}$. The reversibility is clearly demonstrated when aramid sample is cooled to RT and ionic resistivity recovers to $1.2 \cdot 10^{7} \Omega / \mathrm{sqr}$. The difference between the initial resistivity and the value after the heating-cooling cycle could be due to a different distribution of the IL in the MPIA matrix, which affects to the ionic transport ability of the film. From these results, we can conclude that reversibility of the phase-separation process is directly reflected in the ionic conductivity of the aramid films, obtaining conductive aramid films when a single MPIA/IL phase is formed at temperatures around $60^{\circ} \mathrm{C}$.

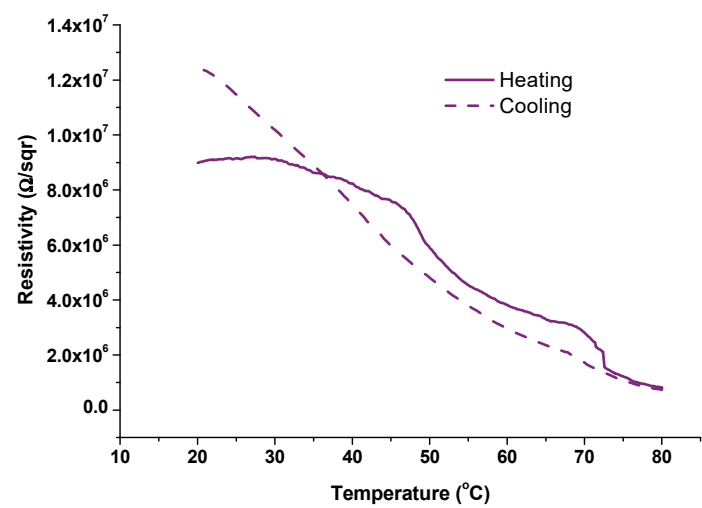

Fig. 4. Ionic resistivity evolution in a heating-cooling cycle from RT to $80{ }^{\circ} \mathrm{C}$ in 50MPIA/50IL aramid film. 


\section{Conclusions}

In short, we present an easy and inexpensive method to produce microporous aramid films with controlled morphology, adding ILs to commercial MPIA, which originated the microporous structure after removal in distilled water. Microcellular aramid films presented values of density between two and five times lower than dense MPIA. In addition, microporous morphology was controlled by the IL proportion, which was varied between 50 and $90 \%$ wt., presenting in all the cases cell sizes below $8 \mu \mathrm{m}$.

Thermal properties of microporous films were analyzed from TGA and DSC measurements, finding that thermal resistance was maintained compared to dense MPIA film, then showing the positive effect of the microporous structure in low density films.

Concerning the mechanical properties, tensile tests were carried out, showing that microporous aramid films presented a reduction of the values of stress at break value around four times, but on the other hand, Young's modulus parameter was surprisingly elevated, compared in relative terms to the value of the dense MPIA for samples with $80 \%$ wt. of IL, then detecting a direct and clear influence of the cell size and the homogeneity of the microporous structure in the mechanical performance of the films.

Ionic conductivity of the MPIA/IL films was also analyzed, detecting that the addition of the IL turned the MPIA film conductive.

Finally, we deeply investigated the reversible thermally-phase separation process associated to the presence of the IL in the MPIA matrix. It was observed that MPIA and IL formed a single phase around $60{ }^{\circ} \mathrm{C}$, detected in several experimental and theoretical ways: visually from different optical photographs taken at several temperatures, through AFM Raman images and spectra at different temperatures and also by measuring the evolution of the ionic resistivity in a heating-cooling cycle, finding that ionic resistivity decreased drastically due to the single-phase formation and turning the aramid film conductive. 
Also, numerical modelling confirmed that the reaction was thermodynamically favorable in good agreement with a strong interaction between the ionic liquid and the polyamide to form a single phase by heating up at $60^{\circ} \mathrm{C}$, obtaining conductive aramid films when a unique MPIA/IL phase was formed, reversing the ionic transport ability when film was cooled to RT (two segregated MPIA/IL phases).

\section{Acknowledgements}

This research has made use of the high-performance computing resources of the Castilla y León Supercomputing Center (SCAYLE, https://www.scayle.es), financed by FEDER (Fondo Europeo de Desarrollo Regional)

\section{Funding}

The financial support provided by FEDER (Fondo Europeo de Desarrollo Regional) and both the Spanish Agencia Estatal de Investigación (MAT201784501-R) and the Consejería de Educación-Junta de Castilla y León (BU306P18) is gratefully acknowledged. 


\section{References}

[1] J.A. Reglero Ruiz, M. Trigo-López, F.C. García, J.M. García, Polymers 2017, 9, 414-458.

[2] M. Trigo-López, J.M. García, J.A. Reglero, F.C. García, R. Ferrer, Aromatic polyamides, in: H.F. Mark (Ed.), Encyclopedia of Polymer Science and Technology, pp. 1-51, John Wiley \& Sons, Inc., New Jersey, 2018.

[3] B.S. Pascual, M. Trigo-López, C. Ramos, M.T. Sanz, J.L. Pablos, F.C. García, J.A. Reglero Ruiz, J.M. García, Eur. Polym. J. 2019, 110, 9-13.

[4] A.I. Cooper, Adv. Mater. 2003, 16, 1049-1059.

[5] J. Pinto, M. Dumon, M. Pedros, J.A. Reglero, M.A. Rodríguez-Pérez, Chem. Eng. J. 2014, 243, 428-435.

[6] J.G. Huddleston, Royal Soc. Chem. 2001, 3, 156-164.

[7] V.D. Da Silva, M.M. Jacobi, H.S. Schrekker, S.C. Amico, J. Appl. Polym. Sci. 2018, 46693-46700.

[8] W. Yang, H. Yu, M. Zhu, H. Bai, Y. Chen, J. Macromol. Sci. B. 2006, 45, 573-579.

[9] S. Dewilde, W. Dehaen, K. Binnemans, Green Chem. 2016, 18, 1639-1652.

[10] S. Dewilde, T.V. Hoogerstraete, W. Dehaen, K. Binnemans, ACS Sustain. Chem. Eng. 2018, 6, $1362-1369$

[11] T. Köddermann, C. Wertz, A. Heintz, R. Ludwig, Angew. Chem. Int. Ed. 2006, 45, 3697-3702.

[12] Y. Cao, Y. Chen, X. Sun, Z. Zhang, T. Mu, Phys. Chem. Chem. Phys. 2012, 14, 12252-12262.

[13] I.H.J. Arellano, J.G. Guarino, F.U. Paredes, S.D. Arco, J. Therm. Anal. Calorim. 2011, 103, 725730.

[14] J.G. Huddleston, A.E. Visser, W.M. Reichert, H.D. Willauer, G.A. Broker, R.D. Rogers, Green Chem. 2001, 3, 156-164.

[15] K.R. Seddon, A. Stark, M.J. Torres, Pure Appl. Chem. 2000, 72, 2275-2287.

[16] L. Cammarata, S. Kazarian, P. Salter, T. Welton, Phys. Chem. Chem. Phys. 2001, 3, 5192-5200.

[17] S. Cuadrado-Prado, M. Domínguez-Pérez, E. Rilo, S. García Garabal, L. Segade, C. Franjo, O. Cabeza, Fluid Phase Equilib. 2009, 278, 36-40.

[18] T. Zhao, W. Wang, Y. Zhang, B. Wang, J. Jiang, Int. J. Mol. Sci. 2007, 8, 680-685.

[19] T. Ueki, M. Watanabe, Macromolecules, 2008, 41, 3739-3749.

[20] J. Wang, J. Luo, S. Feng, H. Li, H. Wan, X. Zhang, Green Energy Environ. 2016, 1, $43-61$.

[21] F. Neese, WIREs Comput Mol Sci 2012, 2, 73-78.

[22] S. Grimme, J.G. Brandenburg, C. Bannwarth, A. Hansen, J. Chem. Phys. 2015, 143, 5410754126.

[23] H. Kruse, S.A. Grimme, J. Chem. Phys. , 2012, 136154101.

[24] S. Grimme, J. Antony, S. Ehrlich, H. Krieg, J. Chem. Phys. 2010, 132, 154104-154123.

[25] F. Weigend, R. Ahlrichs, Phys. Chem. Chem. Phys. 2005, 7, 3297-3305.

[26] F. Weigend, Phys. Chem. Chem. Phys. 2006, 8, 1057-1065.

[27] M. Trigo-López, A. Miguel-Ortega, S. Vallejos, A. Muñoz, D. Izquierdo, A. Colina, F.C. García, J.M. García, Dyes Pigm. 2015, 122, 177-183.

[28] M. Trigo-López, J.L. Barrio-Manso, F. Serna, F.C. García, J.M. García, Macromol. Chem. Phys. 2013, 214, 2223-2231.

[29] K. Täuber, A. Zimathies, J. Yuan, Macromol. Rapid Commun. 2015, 36, 2176-2180.

[30] S. Lakshmi, T. Cundari, E. Furia, A. Tagarelli, G. Fiorani, M. Carraro, A. Figoli, Macromol. Symp. 2015, 357, 159-167.

[31] P. Van de Witte, P.J. Dijkstra, J.W.A. Van den Berg, J. Feijen, J. Membr. Sci. 1996, 117, 1-31.

[32] Z. Liu, D. Sun, W. Dong, S. Feng, C. Xiao, Y. Zhang, J. Wei, Appl. Mech. Mater. 2014 694, 462465.

[33] Y. Chen, Y. Niu, P. Gong, Z. Xiao, G. Li, Macromol. Rapid Commun. 2017, 38, 170040117004018.

[34] J.L. Pablos, N. García, L. Garrido, J. Guzmán, F. Catalina, T. Corrales, P. Tiemblo, J. Membr. Sci. 2018, 545, 133-139.

[35] V.V. Zuev, Y.G. Ivanova, Polym. Eng. Sci. 2012, 52, 1206-1211.

[36] A. Dasari, Z.-Z. Yu, Y.-W. Mai, Polymer 2009, 50, 4112-4121.

[37] B.S. Pascual, S. Vallejos, J.A. Reglero Ruiz, J.C. Bertolín, C. Represa, F.C. García, J.M. García, J. Hazard. Mater. 2019, 364, 238-243. 
Sensory polymeric foams as a tool for improving sensing performance of sensory polymers 



\title{
Sensory Polymeric Foams as a Tool for Improving Sensing Performance of Sensory Polymers
}

Blanca S. Pascual ${ }^{1}$, Saúl Vallejos ${ }^{1}$, Cipriano Ramos ${ }^{2}$, María Teresa Sanz ${ }^{2}$, José A. Reglero Ruiz ${ }^{1, *}$, Félix C. García ${ }^{1}$ and José M. García ${ }^{1, *}$

1Departamento de Química, Facultad de Ciencias, Universidad de Burgos, Plaza de Misael Bañuelos s/n, 09001 Burgos, Spain.

2Departamento de Biotecnología y Ciencia de los Alimentos, Área de Ingeniería Química, Facultad de Ciencias, Universidad de Burgos, Plaza de Misael Bañuelos s/n, 09001 Burgos, Spain.

"Correspondence: jareglero@ubu.es (J.A.R.R.); imiguel@ubu.es (J.M.G.)

\begin{abstract}
Microcellular sensory polymers prepared from solid sensory polymeric films were tested in an aqueous $\mathrm{Hg}(\mathrm{II})$ detection process to analyze their sensory behavior. First, solid acrylic-based polymeric films of $100 \mu \mathrm{m}$ thickness were obtained via radical copolymerization process. Secondly, dithizone sensoring motifs were anchored in a simple five-step route, obtaining handleable colorimetric sensory films. To create the microporous structure, films were foamed in a $\mathrm{ScCO}_{2}$ batch process, carried out at 350 bar and $60{ }^{\circ} \mathrm{C}$, resulting in homogeneous morphologies with cell sizes around $5 \mu \mathrm{m}$. The comparative behavior of the solid and foamed sensory films was tested in the detection of mercury in pure water media at $2.2 \mathrm{pH}$, resulting in a reduction of the response time (RT) around $25 \%$ and limits of detection and quantification (LOD and LOQ) four times lower when using foamed films, due to the increase of the specific surface associated to the microcellular structure.
\end{abstract}




\section{Introduction and objectives}

Limit of detection (LOD), limit of quantification (LOQ) and response time (RT) are three key parameters for describing the behavior of chemosensors, and they are of special relevance for solid sensory polymers, e.g., sensory films, since their specific surface of these solids is low and, at the same time, the diffusion of target chemicals into the dense polymer structure is governed by Fick's law and by their solubility. Sensory polymeric films, specifically colorimetric chemosensory materials, are highly interesting analytical tools because they are inexpensive, they can be managed easily and can be used in situ by unskilled personnel to quantify target species in gas phase or in solution $[1,2]$.

For this reason, it is essential to find ways for improving the performance of polymer chemosensors, in terms of the previously mentioned parameters (LOQ, LOD and RT), maintaining their chemical and physical properties without losing the advantage of detecting target species through simple processes, i.e., by putting into contact a small piece of polymer film with the measuring medium. One possible approach to reduce the LOQ, LOD and RT parameters would be an increase of the specific surface throughout the formation of a microcellular morphology, then enhancing the diffusion rate of the aqueous solution into the material, keeping the manageability of the solid sensory films.

Cellular materials, specifically polymeric foams, have been widely analyzed during the last decades, due to their combination of being low-weight with mechanical and thermal properties. We can cite the classical work of Gibson and Ashby [3] and more recent approaches published by Marsavina et al. [4,5] and Linul et al. [6,7], in which the relation between cellular structure and different properties of cellular materials are deeply investigated. In the last years, the sensory properties of cellular materials have gained a lot of attention, and different research works have been published employing porous materials in sensing applications. For example, Hwang et al. developed micro-resonators based on porous nanowires [8], Kumeria et al. presented colorimetric sensors using mesoporous silicon crystals [9], Jiang et al. prepared humidity sensors 
employing porous polymeric microspheres [10], and Lee et al. prepared fluorescent molecular-scale porous polymeric sensory films for the detection of volatile organic compounds [11]. It is also important to remark that the enhanced sensitivity of foams for analyte detection has also been reported by Wang et al. [12], employing the sensing characteristics of polyurethane foams in amine detection, or the classical work of Park et al., in which porous polymeric films are tested in humidity-sensing applications [13]. Luo et al. [14] described the fabrication of a pressure-sensitive array based on polydimethylsiloxane porous substrate, and a very interesting recent work presented by Liu et al. [15] presented the use of copper foams in glucose-sensing applications.

In parallel, our group has great experience in the fabrication and characterization of colorimetric polymer-based sensory films, which show the ability to detect different target species [16,17]. Recently, we have also investigated the foamability of these sensory films using the direct and clean $\mathrm{ScCO}_{2}$ foaming process [18-20], obtaining very promising results [21]. Compared to other experimental procedures that obtain microporous structures based on chemical reactions, $\mathrm{ScCO}_{2}$ foaming is considered a "green" process, using an inert and non-expensive gas which does not interact chemically with the polymers, simplifying greatly the process and offering the possibility of controlling the porous morphology in terms of the supercritical conditions.

Bearing all these ideas in mind, we decided to verify the previous hypothesis taking advantage of the foamability of our sensory films, selecting a specific application which has also been deeply analyzed previously in our group, to compare the sensing characteristics of solid and $\mathrm{ScCO}_{2}$ foamed microcellular films. It is well known that sensing of heavy metal cations has been investigated in the last decade, and specifically mercury detection has become a fundamental research line due to its toxicity. Different works have been published concerning this topic, using different sensory systems. For example, Yang et al. [22] presented a colorimetric nanosensor based on gold nanoparticles for the detection of $\mathrm{Hg}(\mathrm{II})$ ions; Zhang and Leng [23] reported the development of fluorescent sensors for $\mathrm{Hg}(\mathrm{II})$ cations based on a coumarin-rhodamine system; 
and Xiao et al. [24] described a portable smartphone device for the detection of mercury contamination. Following this research line, we selected a trusted colorimetric sensory polymeric film for detecting $\mathrm{Hg}(\mathrm{II})$ in water solution [25], which has already been tested previously in our group, increasing its specific surface in a single-batch $\mathrm{ScCO}_{2}$ foaming process.

After $\mathrm{ScCO}_{2}$ foaming, sensing of $\mathrm{Hg}(\mathrm{II})$ was carried out employing both solid and foamed samples as colorimetric sensory films, adding dithizone motifs as moieties (DZ), which were chemically anchored to the sensory film. The film was green before the sensing process, and it turned red upon entering into contact with $\mathrm{Hg}(\mathrm{II})$, using this color variation to quantify the concentration of $\mathrm{Hg}(\mathrm{II})$ through the RGB parameters of digital pictures of the sensory film taken with a smartphone. The sensing characteristics of non-foamed samples (dense films) and foamed samples were compared by detecting $\mathrm{Hg}(\mathrm{II})$ in aqueous solution, analyzing specifically the response time (RT), the limit of detection (LOD) and the limit of quantification (LOQ).

\section{Materials and Methods}

The dense pre-sensory film of $115 \mu \mathrm{m}$ thickness was prepared via the radical copolymerization process described in detail in our previous work [25]. 1-Vinyl-2pyrrolidone (VP) was copolymerized with methyl methacrylate (MMA) and 4vinylaniline (VA) with molar percentages of $49.875(\mathrm{VP}) / 49.875(\mathrm{MMA}) / 0.250(\mathrm{VA})$, via radical copolymerization process, using 2,2'-azobis(2-methylpropionitrile) (AIBN) at $1 \mathrm{wt} \%$ molar as a thermal radical initiator. Afterwards, the bulk radical polymerization reaction was carried out in a silanized glass mould in an oxygenfree atmosphere at $60{ }^{\circ} \mathrm{C}$ overnight. The chemical structure of the pre-sensory film is presented in Scheme 1. 


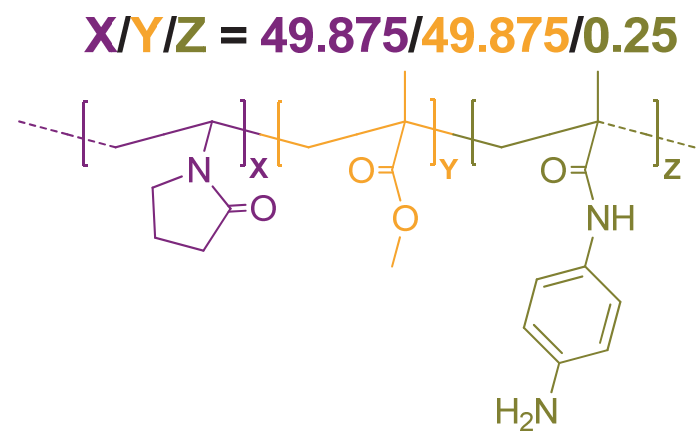

Scheme 1. Chemical structure of the pre-sensory film.

In the second step, the pre-sensory film was transformed into the sensory film by anchoring the DZ motifs to the amino groups of the polymer structure in a five consecutive solid-state reactions procedure, which is also described in our previous work [25], and is depicted in Scheme 2.

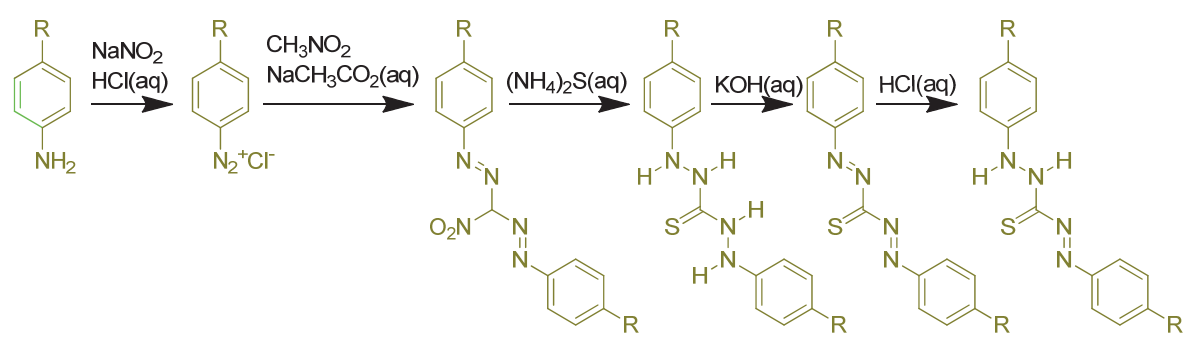

Scheme 2. Five-step route to prepare the sensory film with dithizone-derivative moieties (Reproduced from ref. [25] with permission from The Royal Society of Chemistry).

The sensory film was prepared by immersion of the pre-sensory film in five different and consecutive aqueous reaction media, giving rise to consecutive solid-state reactions. During this process, DZ-derivative motifs were obtained, which acted as cross-linking residues. In the first step, the pre-sensory film was immersed for $30 \mathrm{~min}$ in a solution of $250 \mathrm{~mL}$ of water, $25 \mathrm{~mL}$ of $\mathrm{HCl}$ and $1 \mathrm{~g}$ of $\mathrm{NaNO}_{2}$. The amino functional groups of the anchorage monomer $\mathrm{N}-(4-$ aminophenyl) methacrylamide) react to produce a diazonium salt. Rapidly, and without washing the material, the film was immersed for $90 \mathrm{~min}$ in a solution of $250 \mathrm{~mL}$ of water, $10 \mathrm{~g}$ of sodium acetate and $1 \mathrm{~mL}$ of nitromethane, which induced the cross-linking of the polymer by the formation of bridges of the 2,2'- 
(nitromethylene) bis(1-phenyldiazene) derivative. In the third step, 2-(2-(2phenylhydrazinecarbonothioyl) hydrazinyl) benzene motifs were obtained upon immersion of the film in a solution of $250 \mathrm{~mL}$ of water and $30 \mathrm{~mL}$ of aqueous solution of $\left(\mathrm{NH}_{4}\right)_{2} \mathrm{~S}(20 \%)$ for $90 \mathrm{~min}$. Then, the film was washed thoroughly with water. The fourth step consisted of a deprotonation process using $250 \mathrm{~mL}$ aqueous solution of $\mathrm{KOH} \mathrm{(4 \% )}$ for $30 \mathrm{~min}$ at $50{ }^{\circ} \mathrm{C}$ to obtain the bis (phenyldiazenyl) methanethione intermediate. In the last step, the DZ-derivative moieties were obtained by immersing the membrane in $250 \mathrm{~mL}$ of aqueous solution of $\mathrm{HCl}(4 \%)$ for $1 \mathrm{~min}$, obtaining the sensory film. The final chemical structure of the sensory film is presented in Scheme 3.

\section{$X / Y / Z=49.937 / 49.937 / 0.125$}

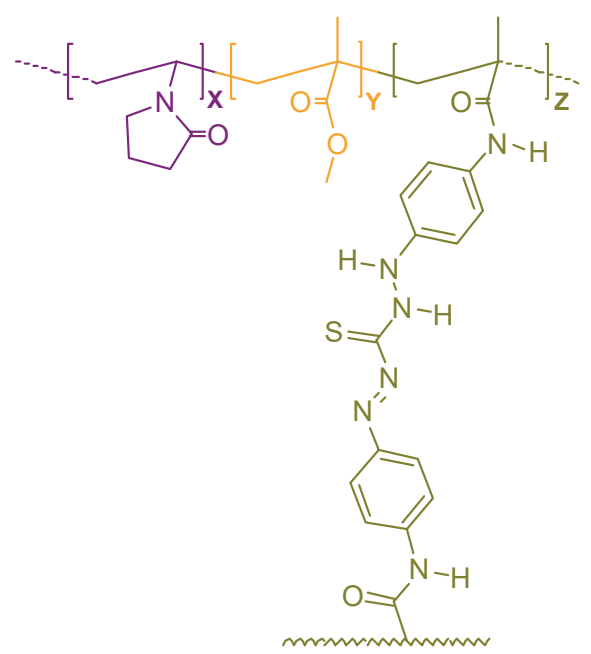

Scheme 3. Chemical structure of the sensory film.

Finally, sensory films were foamed using $\mathrm{ScCO}_{2}$ in a single-step batch process. Films were cut in pieces of $70 \times 35 \mathrm{~mm}^{2}$ and, were partially sandwiched between two steel plates of $50 \times 50 \mathrm{~mm}^{2}$ and $2 \mathrm{~mm}$ thickness. This experimental setup is specifically designed to confine the gas between the steel plates during the depressurization process, limiting the gas diffusion outside the membrane, which is reduced significantly due to the presence of the steel plate, then promoting the cell formation. In order to compare the solid and foamed materials, half of the 
surface of the film was left outside the mold during the $\mathrm{ScCO}_{2}$ process, thus obtaining samples with both solid and foamed regions from an unique starting membrane. This experimental setup, to produce microcellular polymeric films using $\mathrm{ScCO}_{2}$, has been recently described by our group [21] and previously by Siripurapu et al. $[18,19]$. During $\mathrm{ScCO}_{2}$ foaming, samples were saturated with $\mathrm{ScCO}_{2}$ in a high-pressure reactor at $35 \mathrm{MPa}$ and $60{ }^{\circ} \mathrm{C}$ for $24 \mathrm{~h}$, and then depressurized quickly in about $10 \mathrm{~s}$. Figure 1 shows photographs of the experimental set-up and the obtained films together with a couple of SEM micrographs of the foamed region (surface and cross-section). A homogeneous cell structure in the cross-section with an average cell size around $5 \mu \mathrm{m}$ was observed. On the other hand, on the surface of the foamed region of the film, the porous structure presented an irregular cell size distribution, showing smaller cell sizes (around $1 \mu \mathrm{m}$ radii) with isolated larger pores (about $5 \mu \mathrm{m}$ radii).

a)
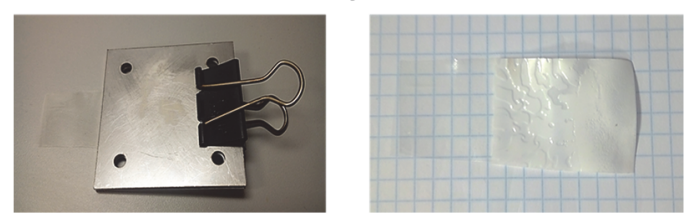

b)
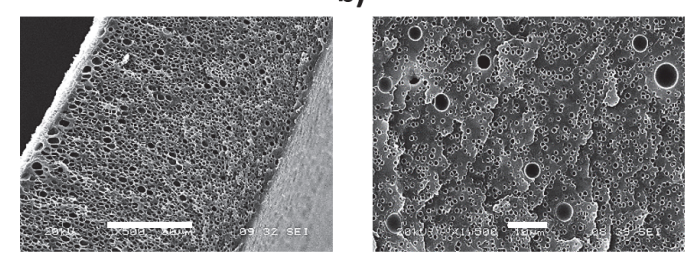

Fig. 1. a) Experimental setup to obtain a film with solid and foamed regions: Steel mold (left) and film after $\mathrm{ScCO}_{2}$ processing with the two regions (right); b) SEM micrographs of the foamed region of the sensory film: Cross-section (left, bar scale $50 \mu \mathrm{m}$ ) and surface (right, bar scale $10 \mu \mathrm{m}$ ). 


\section{Results and Discussion}

The sensing process was carried out using an aqueous solution of $\mathrm{Hg}(\mathrm{II})$ (913 ppm, $\mathrm{Hg}\left(\mathrm{NO}_{3}\right)_{2}, \mathrm{pH} 2.2$ buffered: $\left.\mathrm{KCl} / \mathrm{HCl}\right)$. These conditions were selected for two main reasons: First, the $\mathrm{Hg}$ (II) detection must be carried out in acid media, due to the interference problems observed when using a basic media for the $\mathrm{Hg}$ (II) sensing. Secondly, we employed a high $\mathrm{Hg}$ (II) concentration in order to reduce the detection time and capture in video the whole process. It is possible to use lower concentrations (in the range of $5 \mathrm{ppm}$ ) which are close to the concentration of a real application, but in this case, the detection time would increase up to several hours. Two square samples of $20 \times 20 \mathrm{~mm}^{2}$ were immersed in the solution, one corresponding to the foamed region and the other one extracted from the solid region of the film. Additionally, a plastic piece was placed between both samples and was used as a blank reference in the RGB ( $R$ = red, $\mathrm{G}=$ green, $\mathrm{B}=$ blue) calculations. The whole sensing process was captured in video for $60 \mathrm{~min}$, then extracting different photographs of the color evolution of the discs at different times to perform the RGB analysis. A total number of 26 photographs were extracted from the video, following the next distribution: During the first $20 \mathrm{~min}$, one photograph each minute was taken. Then, from $20 \mathrm{~min}$ to 30 $\mathrm{min}$, one photograph each $5 \mathrm{~min}$, and finally, from $30 \mathrm{~min}$ to $60 \mathrm{~min}$, one photograph each $10 \mathrm{~min}$.

RGB analysis was carried out with a conventional processing image software. To avoid border effects, a circular area of $15 \mathrm{~mm}$ diameter was selected from the picture of each film. In the case of the blank material, a square section of $10 \mathrm{~mm}^{2}$ was delimited. Calculations of RGB parameters of the discs were normalized using the RGB parameters of the reference material, which did not vary during all the sensing processes. Figure 2 shows the experimental setup employed in the $\mathrm{Hg}$ (II) detection process. Each of the images (solid region, foamed region and reference material) was analyzed using a conventional image processing software to determine the RGB parameters at different detection times. The variation along time of color is clearly visible to the naked eye for both regions 
(solid and foamed), and can be graphically seen following the parameters R, G and $B$ of the images, as is shown in Table 1 , in which we present the most representative pictures of both types of discs taken during the detection process, together with the numerical RGB parameters obtained from each image.

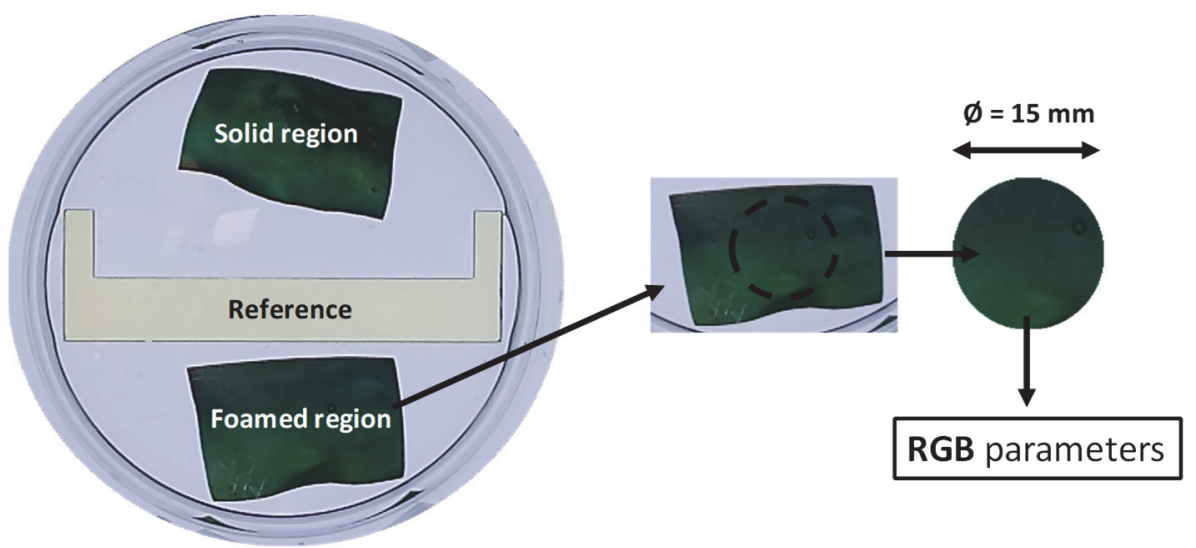

Fig. 2. Detection process: Picture of the Hg(II) solution with the immersed films (left), and circular section selected from the picture of the film to obtain the RGB parameters (right).

Table 1. RGB data from photographs taken from the solid and foamed regions of the sensory films after immersion for $60 \mathrm{~min}$ at $\mathrm{RT}$ in aqueous solutions $(\mathrm{pH}=2.2, \mathrm{KCl}-$ $\mathrm{HCl}$ ) with a fixed concentration (913 ppm) of $\mathrm{Hg}(\mathrm{II})$.

\begin{tabular}{l|ccccccccccc} 
Solid Region \\
Feamed
\end{tabular}

As can be seen in Table 1, the color variation is more intense and also faster when using foamed films, especially in detection times above $15 \mathrm{~min}$. Quantification of this visual evidence can be carried out through the variation of 
the red $(R)$ parameter, which is presented in Figure 3, determining the detection time of the solid and foamed regions of the sensory film. An estimation of the detection time can be carried out using two different linear fittings of the red value evolution. Two different zones are considered in each curve to perform the linear fitting, which is delimited by the saturation value of the red parameter (detection time of foamed (tfoamed) and solid ( $\mathrm{t}_{\text {solid }}$ ) sensory films). In our case, detection time was reduced around $25 \%$, lowering the value from $26 \mathrm{~min}$ in solid films ( $\mathrm{t}_{\text {solid }}$ ) to $19 \mathrm{~min}$ in foamed films (tfoamed). On the other hand, no great differences were observed in the $\mathrm{G}$ (green) and B (blue) parameters, as is shown in Figures S1 and $\mathrm{S} 2$ of Section S1.1 of the Electronic Supplementary Information (ESI) file.

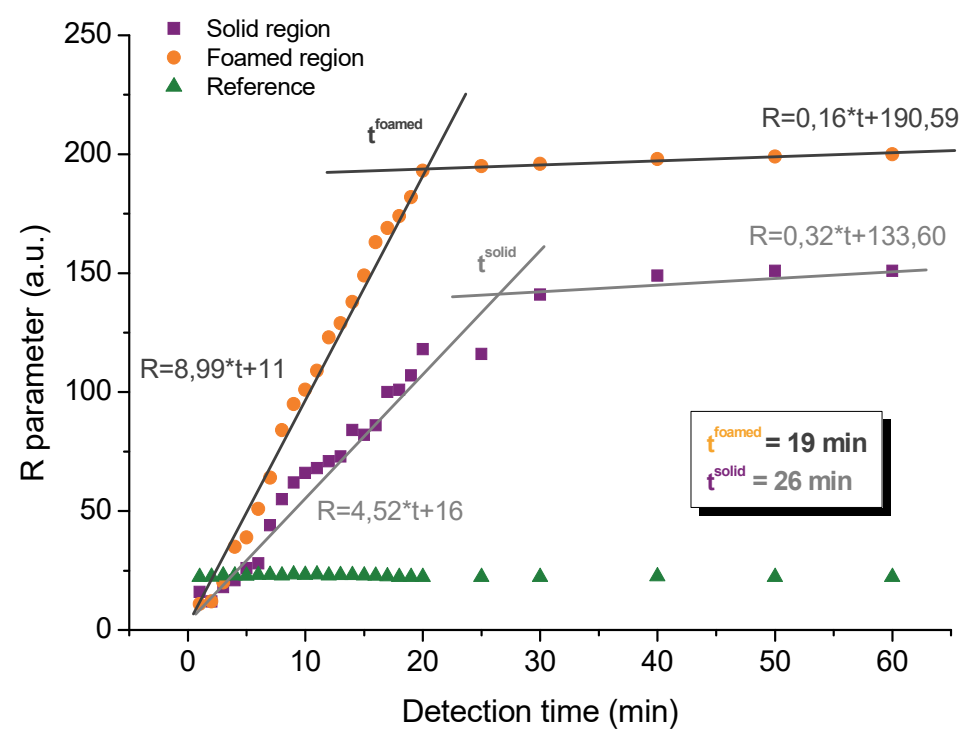

Fig. 3. Evolution of the red parameter $(\mathrm{R})$ of images of sensory films, and reference along time immersed in the aqueous solution of $\mathrm{Hg}(\mathrm{II})\left(913 \mathrm{ppm}, \mathrm{Hg}\left(\mathrm{NO}_{3}\right)_{2}, \mathrm{pH} 2.2\right.$ buffered: $\mathrm{KCl} / \mathrm{HCl}$ ).

Moreover, the red parameter values of the foamed discs are higher through all the detection processes than the values measured for the solid disc. The saturation value of the red parameter for the solid disc is around 150 arbitrary units (a.u.), whereas for the foamed disc this value reaches 200 a.u. Accordingly, the color change is much more visible and is more easily detectable by naked eye when foamed sensory films are used (see pictures of 
the sensory discs in Table 1). Thus, it is concluded that both the detection time and also color intensity are improved when microcellular films are used in the detection of $\mathrm{Hg}(\mathrm{II})$ cations in aqueous solution.

Another key parameter that must be taken into account is the sensitivity of these chemosensors. For this purpose, titration curves of $\mathrm{Hg}(\mathrm{II})$ were carried out using the procedure followed in our previous work, [25] analyzing the RGB parameters of digital pictures taken to the sensory films, using a homemade retro-illumination system to standardize the illumination conditions. To clearly differentiate the sensory materials, samples were cut in squares of $5 \mathrm{~mm}$ a side in the case of solid samples, and in triangles of $5 \mathrm{~mm}$ a side for foamed samples. Samples were immersed into separate water solutions containing $\mathrm{Hg}(\mathrm{II})$ (913 ppm, $\mathrm{Hg}\left(\mathrm{NO}_{3}\right)_{2}$, $\mathrm{pH}$ 2.2, buffered: $\mathrm{KCl} / \mathrm{HCl}$ ).

The principal component $\mathrm{PC} 1$ of the $\mathrm{R}$ and $\mathrm{B}$ parameters allowed for the construction of a titration curve over a range of concentrations (from $1 \times 10^{-7}$ to $3 \times 10^{-6} \mathrm{M}$ ), from which the LOD and LOQ values were calculated (see Table 2), using the following equations: $\mathrm{LOD}=3.3 \times \mathrm{SD} / \mathrm{s}$ and $\mathrm{LOQ}=10 \times \mathrm{SD} / \mathrm{s}$, where $\mathrm{SD}$ is the standard deviation of a blank sample and $s$ is the slope of the calibration curve in a region of low $\mathrm{Hg}(\mathrm{II})$ content. We also include in Table 2, for comparison purposes, the values of LOD and LOQ obtained in our previous work, [25] in which a solid film of the same composition was tested in similar conditions. It is observed that the foamed sensory films present values of LOD and LOQ which are four times lower than the values observed in solid sensory samples, thus confirming the relevant effect of the microcellular structure in the improvement of the performance of the material as a chemosensor.

We present in Section S1.2 of the ESI the principal component analysis PC1 and the titration curve of $\mathrm{Hg}(\mathrm{II})$ from the RGB parameters calculated over the range of concentrations exposed above, for both solid and foamed films, in which the improvement of the sensing behavior when using microcellular foamed films is evident (please see Tables S1 and S2 and also Figures S3 and S4 of the ESI). 
Table 2. Limit of detection (LOD) and limit of quantification (LOQ) values determined from titration curves of $\mathrm{Hg}$ (II) for solid and foamed films, compared to our previous results taken from reference [25].

\begin{tabular}{|c|cc}
\hline Sensory Film & LOD, ppb & LOQ, ppb \\
\hline Solid (this work) & 1.1 & 3.4 \\
Foamed (this work) & 0.3 & 0.9 \\
Solid, Vallejos et al. [25] & 1.6 & 4.8
\end{tabular}

\section{Conclusions}

In short, we have enhanced the performance of sensory polymer films (in terms of detection time, limit of detection and limit of quantification) by preparing foamed microcellular structures. Solid sensory films were foamed via $\mathrm{ScCO}_{2}$ foaming process, and detection of $\mathrm{Hg}(\mathrm{II})$ in aqueous solution was carried out, analyzing the behavior of both solid and foamed films in terms of response time and limit of detection. Results showed that using foamed films led to a reduction in the response time of around $25 \%$, and values of limit of detection and quantification were also improved around twofold with respect to solid films, mainly due to the increased specific surface exposed to the $\mathrm{Hg}(\mathrm{II})$ solution. This $\mathrm{ScCO}_{2}$ foaming process is a straightforward and green alternative procedure for physically improving the performance of known polymer chemosensors without modifying the chemistry, compared to non-environmentally clean, expensive and complicated traditional processes. Moreover, the $\mathrm{ScCO}_{2}$ foaming process could be easily applied to other polymer-based sensory films with good foamability.

Supplementary Materials: The following are available online at www.mdpi.com1424-8220/18/12/4378/s1; Figure S1: Evolution of the green parameter $(G)$ of images of sensory films along time upon entering into contact with a water solution of $\mathrm{Hg}(\mathrm{II})(913 \mathrm{ppm})$, Figure S2: Evolution of the blue parameter $(B)$ of images of sensory films along time upon entering into contact with a water solution of $\mathrm{Hg}$ (II) (913 ppm), Figure S3: Variation of the PC1 vs. the logarithm of the $\mathrm{Hg}(\mathrm{II})$ concentration for foamed discs. Upon fitting with a twodegree polynomial, the mercury concentration in the test sample was calculated, Figure S4: Variation of the PC1 vs. the logarithm of the $\mathrm{Hg}(\mathrm{II})$ concentration for 
solid discs. Upon fitting with a two-degree polynomial, the mercury concentration in the test sample was calculated, Table S1: $\mathrm{Hg}(\mathrm{II})$ concentrations, RGB parameters and PC1 of each foamed disk. Values in red were neglected for plotting the titration curves, Table S2: $\mathrm{Hg}(\mathrm{II})$ concentrations, RGB parameters and PC1 of each solid disk. Values in red were neglected for plotting the titration curves.

Author Contributions: B.S.P. and S.V. prepared the solid polymeric films and carried out the $\mathrm{Hg}(\mathrm{II})$ sensing process; C.R. performed the $\mathrm{ScCO}_{2}$ foaming process; J.A.R.R. characterized the microcellular polymeric films and prepared the draft of the manuscript; M.T.S., F.C.G. and J.M.G. revised and corrected the final version of the manuscript.

Funding: The financial support provided by FEDER (Fondo Europeo de Desarrollo Regional) and both the Spanish Agencia Estatal de Investigación (MAT2017-84501-R) and the Consejeria de Educación-Junta de Castilla y León (BU306P18) is gratefully acknowledged.

Conflicts of Interest: The authors declare no conflict of interest. 


\section{References}

[1] J.M. García, F.C. García, F. Serna, J.L. de la Peña, Polym. Rev. 2011, 51, 341-390.

[2] J.A. Reglero Ruiz, A.M. Sanjuán, S. Vallejos, F.C. García, J.M. García, Chemosensors 2018, 6, 12 ,

[3] L.J. Gibson, M.F. Ashby, Cellular Solids: Structure and Properties, 2nd ed.; Cambridge University Press: Cambridge, UK, 1997.

[4] L. Marsavina, D.M. Constantinescu, E. Linul, F.A. Stuparu, D.A. Apostol, Eng. Fract. Mech. 2016, $167,68-83$.

[5] L. Marsavina, D.M. Constantinescu, E. Linul, D.A. Apostol, T. Voiconi, T. Sadowski, Eng. Fract. Mech. 2014, 129, 54-66.

[6] E. Linul, L. Marsavina, P.-A. Linul, J. Kovacik, Compos. Struct. 2019, 209, 490-498.

[7] E. Linul, N. Movahedi, L. Marsavina, J. Alloys Compd. 2018, 740, 1172-1179.

[8] S. Hwang, W. Kim, H. Yoon, S. Jeon, ACS Sens. 2017, 2, 1355-1358.

[9] T. Kumeria, J. Wang, N. Chan, T.J. Harris, M.J. Sailor, ACS Sens. 2018, 3, 143-150.

[10] K. Jiang, H. Zhao, J. Dai, D. Kuang, T. Fei, T. Zhang, ACS Appl. Mater. Interfaces 2016, 8, 2552925534.

[11] W.-E Lee, C.-J. Lee, T. Sakaguchi, M. Fujiki, G. Kwak, Macromolecules 2011, 44, 432-436.

[12] Y. Wang, G.A. Sotzing, R.A. Weiss, Chem. Mater. 2003, 15, 375-377.

[13] C.B. Park, Y.-H. Lee, S.B. Yi, Sens. Actuators B Chem. 1993, 13, 86-88.

[14] Y. Luo, Q. Xiao, B. Li, Sensors 2017, 17, 1571-1583.

[15] F. Liu, Y. Zhuang, M. Guo, Y. Chen, J. Tu, L. Ding, Sensors 2018, 18, 1131-1142.

[16] S. Vallejos, A. Muñoz, F.C. García, R. Colleoni, R. Biesuz, G. Alberti, J.M. García, Sens. Actuators B Chem. 2016, 233, 120-126.

[17] J.L. Pablos, A. Muñoz, S. Ibeas, F. Serna, F.C. García, J.M. García, J. Mater. Chem. A 2015, 3, 2833-2843.

[18] S. Siripurapu, R.J. Desimone, S.A. Khan, J.M. Spontak, Adv. Mater. 2004, 16, 989-993.

[19] S. Siripurapu, J.M. DeSimone, S.A. Khan, R.J. Spontak, Macromolecules 2005, 38, 2271-2278.

[20] Y. Luo, D. Yajun, W. Changchun, T. Linghua, Y. Sanjiu, J. Thermoplast. Compos. Mater. 2017, 30, 1713-1727.

[21] J.A. Reglero Ruiz, S. Vallejos, B.S. Pascual, C. Ramos, S. Beltrán, F.C. García, J.M. García, J. Supercrit. Fluids 2018, 140, 270-278.

[22] P.-C. Yang, T. Wu, Y.-W. Lin, Sensors 2018, 18, 2807-2821.

[23] Y. Zhang, J. Leng, Sensors 2017, 17, 1672-1686

[24] W. Xiao, M. Xiao, Q. Fu, S. Yu, H. Shen, H. Bian, Y. Tang, Sensors 2016, 16, 1871-1882.

[25] S. Vallejos, J.A. Reglero, F.C. García, J.M. García, J. Mater. Chem. A 2017, 5, 13710-13716. 


\section{CONCLUSIONES CONCLUSIONS}

El desarrollo de este trabajo ha permitido establecer una estrategia para mejorar los materiales sensores poliméricos, tanto química como físicamente.

The development of this research has enabled the establishment of a strategy to improve the polymeric sensory materials, both chemically and physically.

Las conclusiones particulares derivadas del trabajo son las siguientes:

The conclusions drawn from this research would be the followings:

- El anclaje de sales de diazonio a una matriz polimérica en forma de filme provee a estos compuestos de una estabilidad química y ambiental muy superior a la que presentan en su forma discreta y permite la detección colorimétrica de fenoles en medio acuoso. En este sentido, esta estrategia se podría extender a otros grupos sensibles a condiciones químicas o ambientales.

The anchoring of diazonium salts to a polymeric matrix in the form of a film gives these compounds a chemical and environmental stability far higher than the ones presented in its discrete form and allows the colorimetric detection of phenols in aqueous medium. In this way, this strategy could be extended to other sensitive to chemical or environmental conditions groups. 
- La generación de una respuesta dual en un filme sensor de atmósferas oxidantes, permite una mejor detección al producirse dos señales de salida fácilmente cuantificables, como son la variación de conductividad y el cambio de color del filme sensor. La respuesta múltiple es una alternativa que mejora sensiblemente la calidad de la respuesta del sensor, ofreciendo mayor fiabilidad.

The dual response of a sensory film toward oxidizing atmosphere, allows for a high-quality detection due to the concomitant of two easily quantifiable output signals, such as variation of the conductivity and the color change of the sensory film. The multiple response is an alternative that improves considerably the quality of the sensor response, providing higher reliability.

- La generación de estructuras microporosas se puede llevar a cabo en filmes vinílicos mediante espumado con $\mathrm{CO}_{2}$ supercrítico, y en poliamidas aromáticas mediante el empleo de líquidos iónicos como promotores del espumado. Así mismo, el empleo de líquidos iónicos en aramidas permite la generación de estructura microporosa por separación de fases por inducción térmica, y su posterior eliminación con agua genera la espuma. Aunque el espumado con $\mathrm{CO}_{2}$ supercrítico es un proceso conocido para polímeros vinílicos, no lo es la obtención de materiales espumados a través de la utilización de líquidos iónicos, lo que abre un nuevo campo en este tipo de materiales.

The generation of microporous structures can be carried out in vinylic films by a foaming process with supercritical $\mathrm{CO}_{2}$ and, in the case of aromatic polyamides, by using ionic liquids as foaming promoters. Likewise, the use of ionic liquids in aramids enables the generation of a microporous structure by thermally induced phase separation and its subsequent removal with water generates the foam. Although foaming 
with supercritical $\mathrm{CO}_{2}$ is a process known for vinylic polymers, obtaining foamed materials employing ionic liquids is not, which opens a new line of research for this kind of materials.

- La generación de estructura microporosa en un filme vinílico supone una mejora del material sensor atendiendo a parámetros como el tiempo de respuesta y los límites de detección y cuantificación. Esta mejora permite el diseño de sensores con mejores prestaciones partiendo de grupos sensores ya publicados.

The generation of microporous structure in a vinylic film results in an improvement of the sensory material regarding to parameters as response time and limits of detection and quantification. This improvement allows for the design of sensors with better performances based on sensory groups already published. 


\section{INDEX}

Polymer films containing chemically anchored diazonium salts with long term 1 stability as colorimetric sensors.

S1. Thermogravimetric analysis of $\mathrm{F}_{005}, \mathrm{~F}_{025}$ and $\mathrm{F}_{10}$

S2. Response time 2

S3. Characterization of the model compound with 1-naphtol 3

S4. Characterization of the linear polymer 4

S5. Data sheet of the tested fungicide based on 2-phenylphenol 5

S6. Titration of phenols with $F_{005} B$ and $F_{025} B$ by the analysis of the RGB parameters and 6 the UV-Vis spectra of each disk

Easy and inexpensive method for the visual and electronic detection of 19 oxidants in air by using vinylic films with embedded aniline

$\begin{array}{ll}\text { S1. Detection procedure } & 19\end{array}$

S1.1. Quantitative detection of oxidants in air by using colour change:RGB and UV-Vis 19

S1.1.1. RGB parameters 20

S1.1.2. UV-Vis spectroscopy 22

S1.2. Qualitative detection of oxidants using visual alarm system 22

S1.3. Quantitative detection of chlorine using four-probe/inductive sensor 23

$\begin{array}{ll}\text { S2. Principal component analysis data } & 26\end{array}$

$\begin{array}{lr}\text { S3. FTIR analysis of the films } & 27\end{array}$

$\begin{array}{ll}\text { S4. SEM micrographs of the surface of the films } & 27\end{array}$

$\begin{array}{llr}\text { S5. Interference studies } & 27\end{array}$ 
Microcellular foamed aromatic polyamides (aramids). Structure, thermal and 28 mechanical properties

S1. Additional results

S1.1. Determination of glass transition temperatures from DSC curves

S1.2. TGA measurements

S1.3. Stress-strain curves

S1. Photographs of the aramid films before and after the removal of the IL

S2. ${ }^{1} \mathrm{H}-\mathrm{NMR}$ of the 40MPIA/60IL aramid film before the removal of IL

S3. SEM micrographs of the surfaces of the porous aramid film

S4. AFM Raman images at different temperatures of 50MPIA/50IL film

S5. Ionic liquid distribution and pore morphology in 50MPIA/50IL film

S6. Theoretical calculations of the polyamide-lonic liquid interaction

S7. TGA curves

S8. DSC curves

S9. Tensile tests

Sensory polymeric foams as a tool for improving sensing performance of 43 sensory polymers

S1. Colorimetric detection of $\mathrm{Hg}(\mathrm{II})$

51.1. Green (G) and Blue (B) parameters variation of images of sensory disks and the 43 reference material

S1.2. Titration of $\mathrm{Hg}(\mathrm{II})$ examining the analysis of the RGB parameters of both foamed and 44 solid disks using a digital picture

S1.2.1. Foamed disks

S1.2.2. Solid disks 


\section{Polymer films containing chemically anchored diazonium salts with long-term} stability as colorimetric sensors

Saúl E. Bustamante ${ }^{b}$, Saúl Vallejos",a, Blanca Sol Pascual-Portala , Asunción Muñoz ${ }^{a}$, Aránzazu Mendía ${ }^{a}$, Félix C. García ${ }^{a}$, Bernabé L. Rivas ${ }^{*}$, , José M. García, ${ }^{\star}, a$

a Departamento de Química, Facultad de Ciencias, Universidad de Burgos, Plaza de Misael Bañuelos s/n, 09001 Burgos, Spain. Fax: (+) 34947258 831, Tel: (+) 34947258 085. E-mail: jmiguel@ubu.es, svallejos@ubu.es

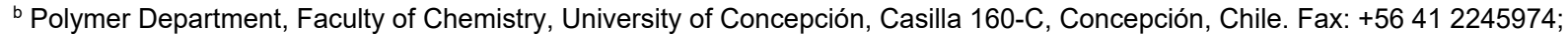
Phone: +56 41 2203373. E-mail: brivas@udec.cl

S1. Thermogravimetric analysis of $F_{005}, F_{025}$ and $F_{10 .}$

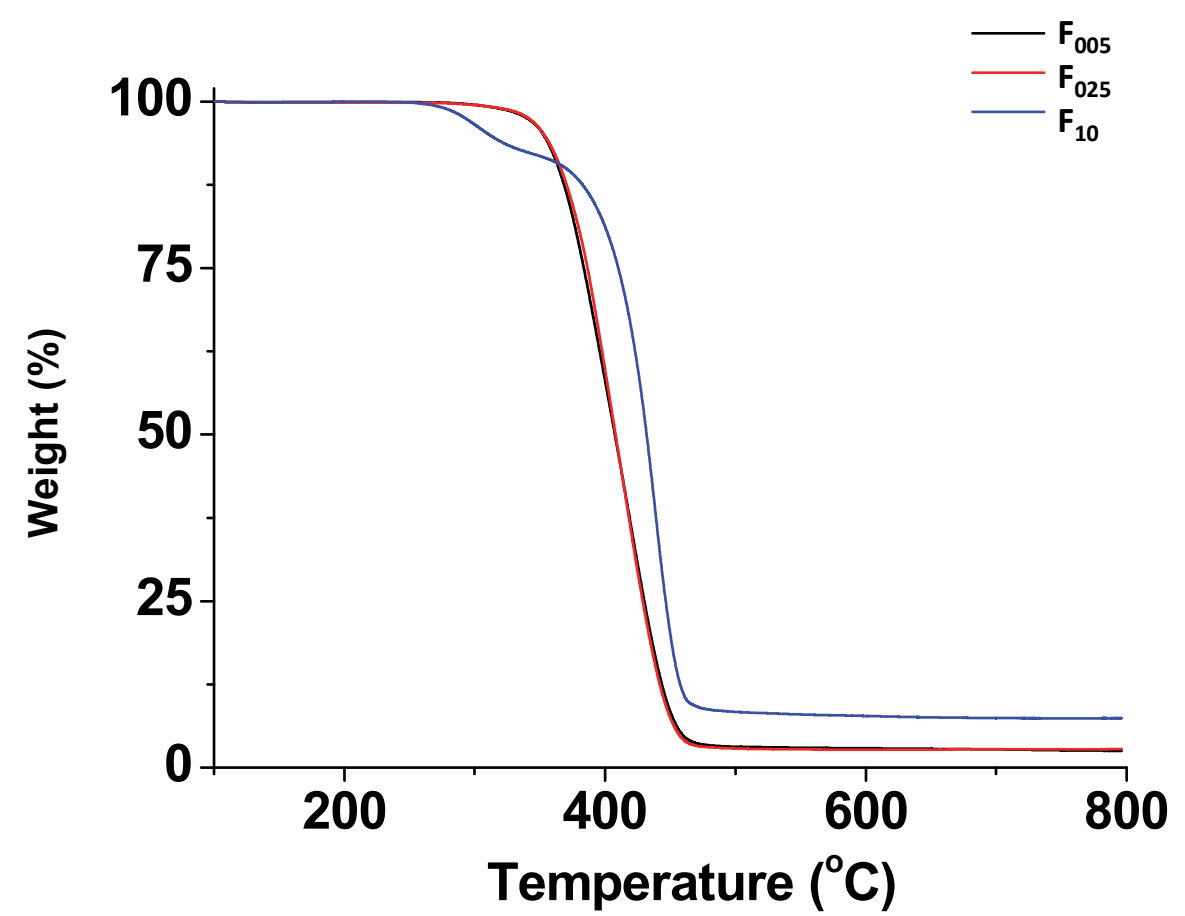

Fig. S1. Thermogravimetric curves at $10{ }^{\circ} \mathrm{C} / \mathrm{min}$ for $\mathbf{F}_{005}, \mathbf{F}_{025}$ and $\mathbf{F}_{10}$ under nitrogen atmosphere. 


\section{S2. Response time}

a)

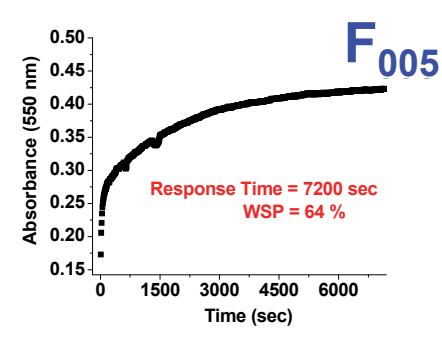

b)

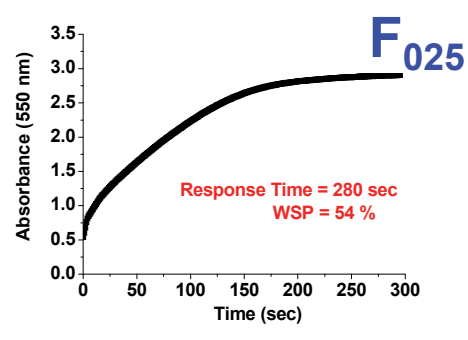

c)

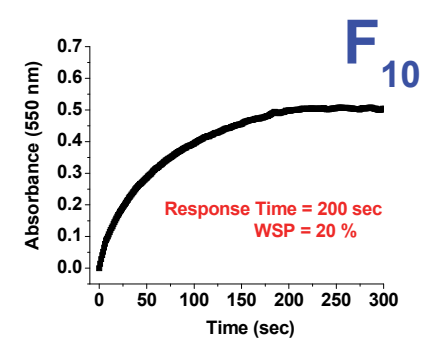

d)

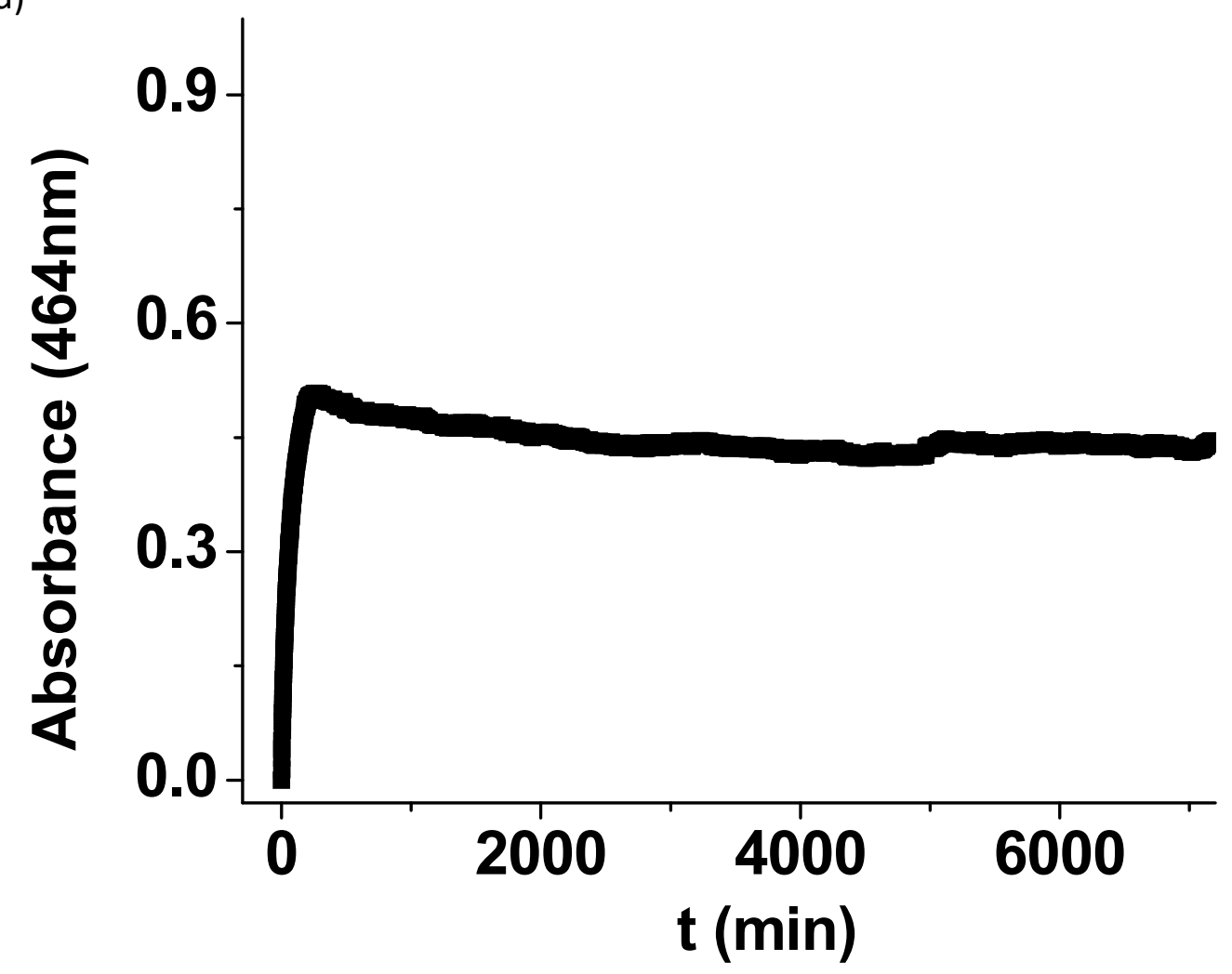

Fig. S2. Graphical representation for the response time of $\mathbf{F}_{005} \mathbf{B}(\mathbf{a}), \mathbf{F}_{025} \mathbf{B}(\mathbf{b})$ and $\mathbf{F}_{10} \mathbf{B}$ (c). $8 \mathrm{~mm}$ discs of each material were embedded in an adapter inside the cuvette. Then, $3 \mathrm{~mL}$ of an aqueous solution of $\mathrm{NaOH} 0.1 \mathrm{M}$ and 1-naphthol $0.01 \mathrm{M}$ solution was added to the cuvette, and the formation of a color band centered at $550 \mathrm{~nm}$ was registered with the UV-Vis until reaching the equilibrium of the system. Graphical representation of the stability of $\mathbf{F}_{005} \mathbf{B}$ in DECCO for 5 days (d). One disc of $F_{005} B$ was dipped in DECCO (see ESI, Section S5), and the absorbance at $464 \mathrm{~nm}$ was registered each minute for five days. 


\section{S3. Characterization of the model compound with 1-naphthol.}

\section{Synthesis of (E)-4-(p-tolyldiazenyl)naphthalen-1-ol (1).}

The synthesis of (1) was carried out by the experimental procedure depicted by I. B. OBOT et al. [1] Yield: 40 \%. ${ }^{1} \mathrm{H}-\mathrm{NMR}$ (399.94 MHz; DMSO-d $\left.\mathrm{d}_{6}\right)$ $\delta(\mathrm{ppm}), 11.06(\mathrm{~s}, 1 \mathrm{H}) ; 8.88(\mathrm{~d}, 1 \mathrm{H}, 8.4 \mathrm{~Hz}) ; 8.21(\mathrm{~d}, 1 \mathrm{H}$, $8.3 \mathrm{~Hz}) ; 7.83(\mathrm{~m}, 3 \mathrm{H}) ; 7.67$ (t, $1 \mathrm{H}, 7.6 \mathrm{~Hz}) ; 7.56$ (t, 1H, $7.5 \mathrm{~Hz}) ; 7.36$ (d, 2H, $7.7 \mathrm{~Hz}) ; 7.00$ (d, 1H, 8.3 $\mathrm{Hz}$ ); 2.37 (s, 3H). ${ }^{13} \mathrm{C}-\mathrm{NMR}$ (100.58 MHz; DMSO-d $)$ : $\delta$ (ppm), 157.80, 151.28, 140.91, 139.95, 133.00, $130.33,128.06,125.82,124.80,123.02,122.85,122.81,114.04,108.78,21.43$. El-HRMS m/z: Calc for [C $\left.{ }_{12} \mathrm{H}_{9} \mathrm{Br}\right]: 262.1106$, found: 262.1104 .

a)

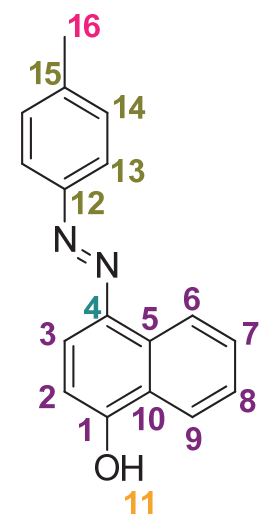

c)

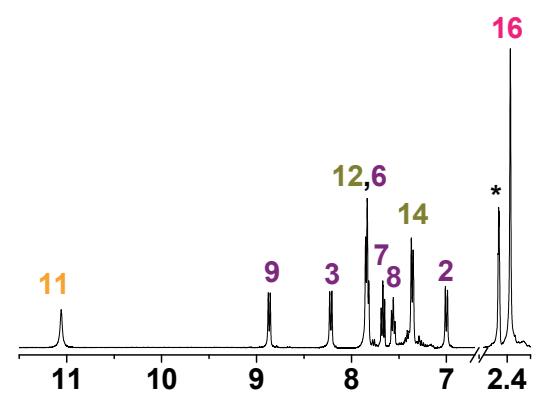

(ס) ppm b)

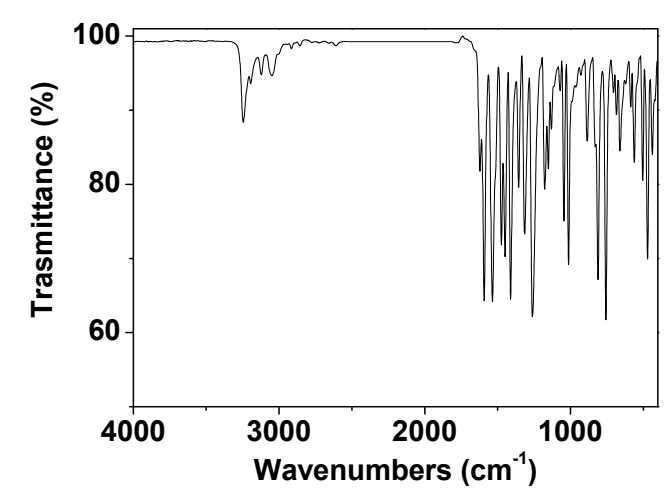

d)

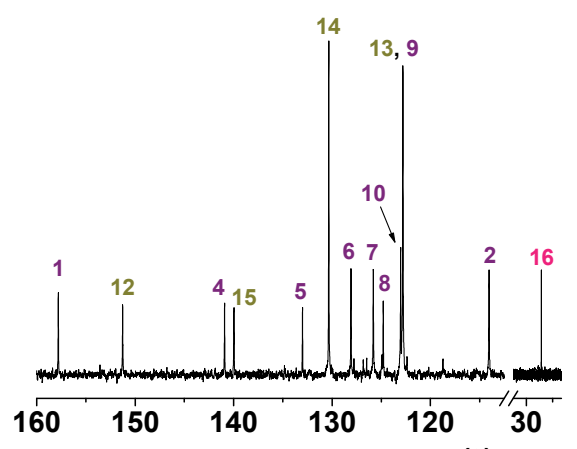

(ठ) $\mathrm{ppm}$

Fig. S3. Characterization of (1) by (b) FTIR, (c) ${ }^{1} \mathrm{H}$ NMR, and (d) ${ }^{13} \mathrm{C}$ NMR. $\left({ }^{*}=\right.$ solvent signal, DMSO$\left.d_{6}\right)$.

[1] V. Mkpenie, G. Ebong, I.B. Obot and B. Abasiekong, E- J. Chem., 2008, 5, 431-434. 


\section{S4. Characterization of the linear polymer}

The linear copolymer was prepared by radical polymerization of VP, MMA and $\mathrm{SNH}_{2}$ in a 45/45/10 molar ratio, respectively. $18 \mathrm{mmol}(2 \mathrm{~g})$ of VP, $18 \mathrm{mmol}(1.8 \mathrm{~g})$ of MMA and $4 \mathrm{mmol}(476 \mathrm{mg})$ of SNH $\mathrm{S}_{2}$ were dissolved in DMF $(40 \mathrm{~mL})$ and added to the flask. Subsequently, the radical thermal initiator AIBN (656 $\mathrm{mg}, 4 \mathrm{mmol}$ ) was added and the solution was heated to $60^{\circ} \mathrm{C}$ overnight. The solution was then added dropwise to diethyl ether $(300 \mathrm{~mL})$ with vigorous stirring to yield the product as a white precipitate. The polymer was purified by soxhlet extraction with diethyl ether. The final product was dried overnight in a vacuum oven at $60^{\circ} \mathrm{C}$. Yield: $93 \%(4 \mathrm{~g})$.

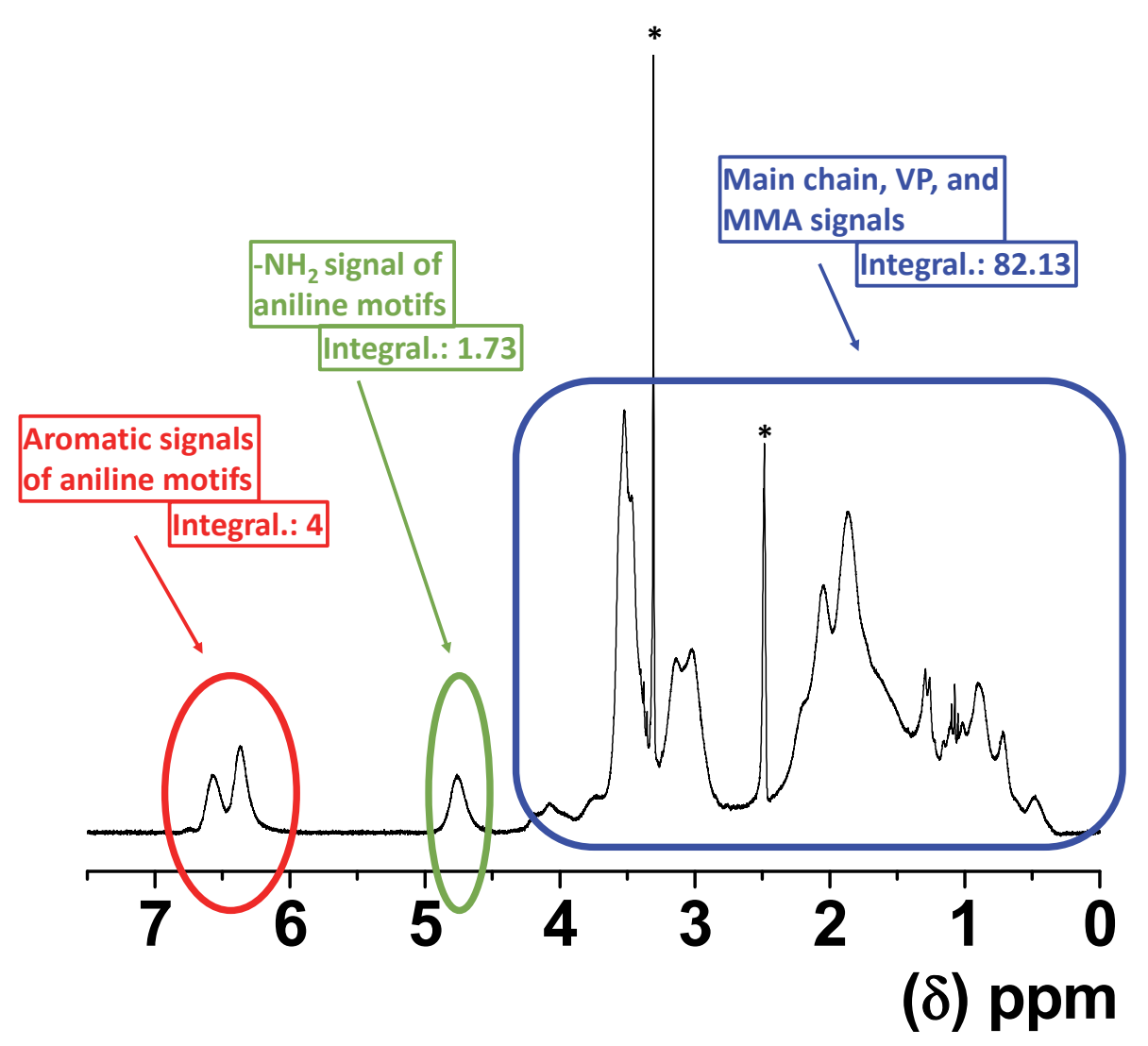

\begin{tabular}{l} 
Molar \% of $\mathrm{SNH}_{2}$ in the feed mixture: $10 \%$ \\
Molar \%ratio of $\mathrm{SNH}_{2}$ from the ${ }^{1} \mathrm{H}$ NMR calculations: $9.67 \%$ \\
\hline
\end{tabular}

Fig. S4. ${ }^{1} \mathrm{H}$ RMN (DMSO- $d_{6}$ ) of the linear polymer obtained from VP, MMA, and $\mathrm{SNH}_{2}$ in a feed molar ratio of $45: 45: 10$, respectively. The signals of the residual solvents $\left(^{*}\right)$ have not been taken into account for the integral calculations. 


\title{
S5. Data sheet of the tested fungicide based on 2-phenyphenol.
}

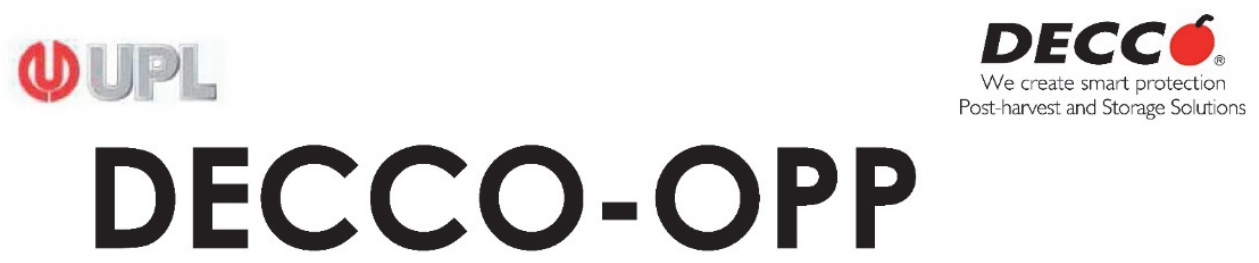

Fungicida de síntesis para poscosecha de cítricos

\author{
Ficha Técnica \\ Fecha emisión 03.01.2018 \\ Versión: 03 \\ Inscrito en el Registro Oficial de Productos Fitosanitarios con el n²4.751/19
}

ADVERTENCIA: Las recomendociones e información que facilitamos son fruto de amplios y rigurosos estudios y ensayos. Sin embargo, en la utilización

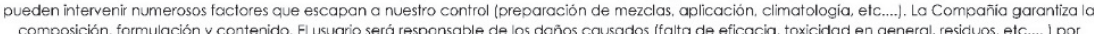
composición, formulación y contenido. El usuario será responsable de los doños causados (falta de eficacia, toxicidad en general, residuos, etc..... ) por

CARACTERÍ́STICAS Y USOS AUTORIZADOS

Tratamiento fungicida para uso en poscosecha contra hongos causantes de podrido en frutos cítricos. Decco-OPP es eficaz contra Penicillium y Rhizopus, entre otros.

\section{DOSIS Y MODO DE EMPLEO}

Para tratamiento en duchas (drencher) 0 por inmersión (balsa), aplicar a razón de 0.5 $-0.6 \%$ (500-600 cc por 100 litros de agua). La aplicación se realizará mediante duchas (sistema drencher) o bien por inmersión de la fruta en balsa de tratamiento, durante 30 segundos, en un baño utilizando aproximadamente 1 litro de caldo por cada $200 \mathrm{~kg}$ de fruta. Aplicar lo más pronto posible después de la recolección.

Cuando así lo exija la legislación vigente, en los embalajes en que se expenda la fruta tratada deberá incluirse una etiqueta con el texto: "Frutos con protección fungicida de ortofenilfenol".

En caso de exportación deberá atenderse a la legislación vigente en el país importados.

Aplicación bajo Asesoramiento Técnico

COMPOSICIÓN

Ortofenilfenol $10 \% \mathrm{p} / \mathrm{v}(100 \mathrm{~g} / \mathrm{L})$

FORMULACIÓN

EC (Concentrado emulsionable)

\section{PRESENTACIÓN}

Garrafas de 20 litros.

\section{PRECAUCIONES}

Provoca lesiones oculares graves

Se sospecha que provoca cáncer

Pedir instrucciones especiales antes del uso y no manipular la sustancia antes de haber leído y comprendido todas las instrucciones de seguridad.

Llevar guantes, prendas y gafas de protección. EN CASO DE CONTACTO: Aclarar cuidadosamente con agua durante varios minutos. Quitar las lentes de contacto, si lleva y resulta fácil. Seguir aclarando.

El preparado no se usará en combinación con otros productos

EN CASO DE ACCIDENTE O MALESTAR, ACUDA INMEDIATAMENTE AL MÉDICO,

(si es posible muéstrele la etiqueta).

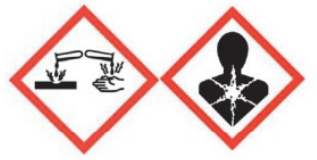

PELIGRO

\section{VENTAJAS DE DECCO-OPP}

$\checkmark$ Fungicida de amplio espectro

$\checkmark$ Eficaz contra Penicillium y Rhizopus, entre otros

$\checkmark$ Residuos autorizados en UE y USA

$\checkmark$ Compatibilidad y sinergia positiva con otros fungicidas

Fig. S5. Data sheet of the product DECCO-OPP containing 100 $/ \mathrm{L}$ of 2-phenylphenol. 
Material suplementario. Capitulo 2 Polymer films containing chemically anchored diazonium salts with long-term stability as colorimetric

\section{S6. Titration of phenols with $F_{005} B$ and $F_{025} B$ by the analysis of the RGB}

\section{parameters and the UV-Vis spectra of each disk.}

a) (Phenol A) $m$-cresol

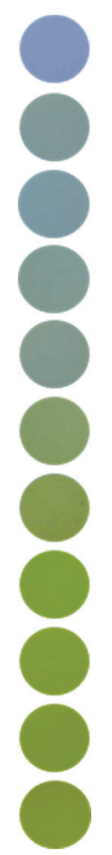

b)

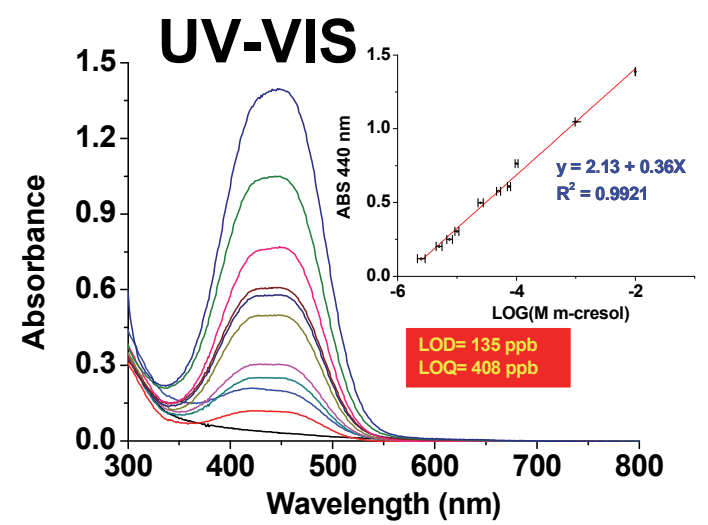

0

$2.50 \times 10^{-6}$

$5.00 \times 10^{-6}$

$7.50 \times 10^{-6}$

$1.00 \times 10^{-5}$

$2.50 \times 10^{-5}$

$5.00 \times 10^{-5}$

$7.50 \times 10^{-5}$

$1.00 \times 10^{-4}$

$1.00 \times 10^{-3}$

$1.00 \times 10^{-2}$
Molar Concentrations

c)

\begin{tabular}{|c|c|c|}
\hline \multicolumn{3}{|c}{ Color } \\
$\mathbf{R}$ & $\mathbf{G}$ & $\mathbf{B}$ \\
129 & 148 & 180 \\
128 & 147 & 151 \\
131 & 146 & 128 \\
131 & 148 & 125 \\
134 & 152 & 113 \\
137 & 153 & 58 \\
134 & 148 & 45 \\
\hline 131 & 140 & 23 \\
127 & 143 & 7 \\
126 & 121 & 0 \\
118 & 106 & 0 \\
\hline
\end{tabular}

UV-Vis Abs $(\mathbf{4 4 0} \mathrm{nm})$

0.036

0.119

0.202

0.249

0.304

0.498

0.577

0.608

0.764

1.047

1.387

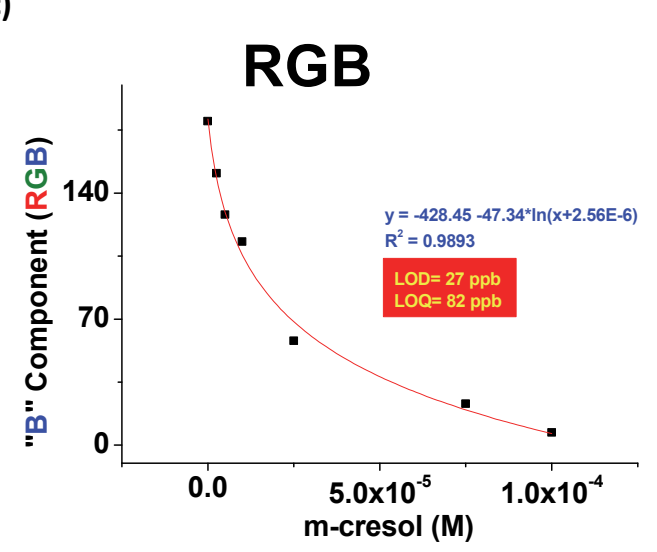

Fig. S6. a) Digital photograph of $\mathrm{F}_{005}$ discs after immersion for $60 \mathrm{~min}$ at RT in aqueous solutions $(\mathrm{NaOH} 0.1 \mathrm{M})$ containing different quantities of $m$-cresol. Data table with the used molar concentrations, RGB parameters obtained from the digital photograph and the absorbance data at the maximum of the color band in the UV-vis spectra. b) UV-Vis spectra, titration curve of $m$-cresol with $F_{005}$, obtained LOD \& LOQ and the fitting equation. c) Variation of the blue component (RGB) vs the $m$-cresol concentration, obtained LOD \& LOQ and the fitting equation. 
Material suplementario. Capitulo 2 Polymer films containing chemically anchored diazonium salts with long-term stability as colorimetric

a) (Phenol B) 2chlorophenol

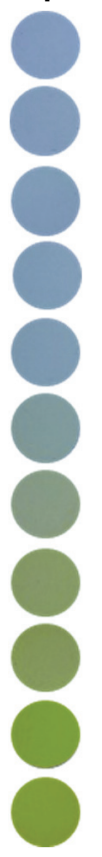

b)

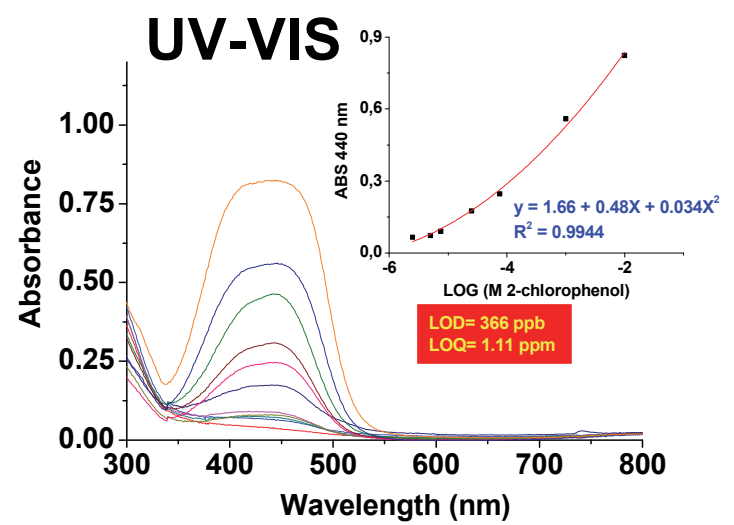

Molar Concentrations

\section{0}

$2.50 \times 10^{-6}$

$5.00 \times 10^{-6}$

$7.50 \times 10^{-6}$

$1.00 \times 10^{-5}$

$2.50 \times 10^{-5}$

$5.00 \times 10^{-5}$

$7.50 \times 10^{-5}$

$1.00 \times 10^{-4}$

$1.00 \times 10^{-3}$

$1.00 \times 10^{-2}$

c)

\begin{tabular}{|c|c|c|c|}
\hline \multicolumn{3}{|c|}{ Color } & \multirow{2}{*}{$\begin{array}{c}\text { UV-Vis } \\
\text { Abs (440 nm) }\end{array}$} \\
\hline $\mathbf{R}$ & G & B & \\
\hline 130 & 149 & 179 & 0.038 \\
\hline 130 & 150 & 175 & 0.065 \\
\hline 127 & 148 & 169 & 0.073 \\
\hline 128 & 150 & 164 & 0.090 \\
\hline 131 & 151 & 159 & 0.080 \\
\hline 130 & 148 & 131 & 0.175 \\
\hline 127 & 147 & 94 & 0.308 \\
\hline 125 & 144 & 60 & 0.246 \\
\hline 124 & 142 & 50 & 0.461 \\
\hline 123 & 130 & 1 & 0.559 \\
\hline 120 & 127 & 1 & 0.823 \\
\hline
\end{tabular}
sensors

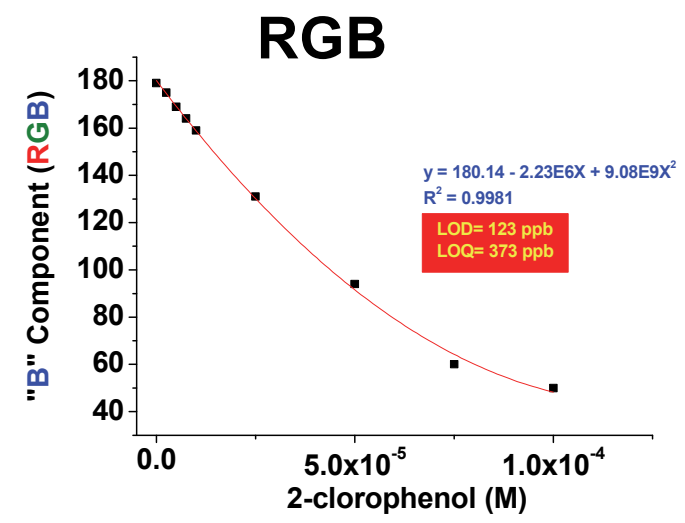

Fig. S7. a) Digital photograph of $\mathbf{F}_{005}$ discs after immersion for $60 \mathrm{~min}$ at RT in aqueous solutions $(\mathrm{NaOH} 0.1 \mathrm{M})$ containing different quantities of 2-chlorophenol. Data table with the used molar concentrations, RGB parameters obtained from the digital photograph and the absorbance data at the maximum of the color band in the UV-vis spectra. b) UV-Vis spectra, titration curve of 2-chlorophenol with $F_{005}$, obtained LOD \& LOQ and the fitting equation. c) Variation of the blue component (RGB) vs the 2-chlorophenol concentration, obtained LOD \& LOQ and the fitting equation. 
Material suplementario. Capitulo 2 Polymer films containing chemically anchored diazonium salts with long-term stability as colorimetric

a) (Phenol C) bisphenol-A Molar Concentrations

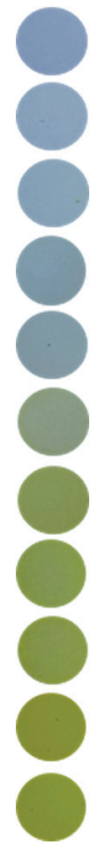

b)

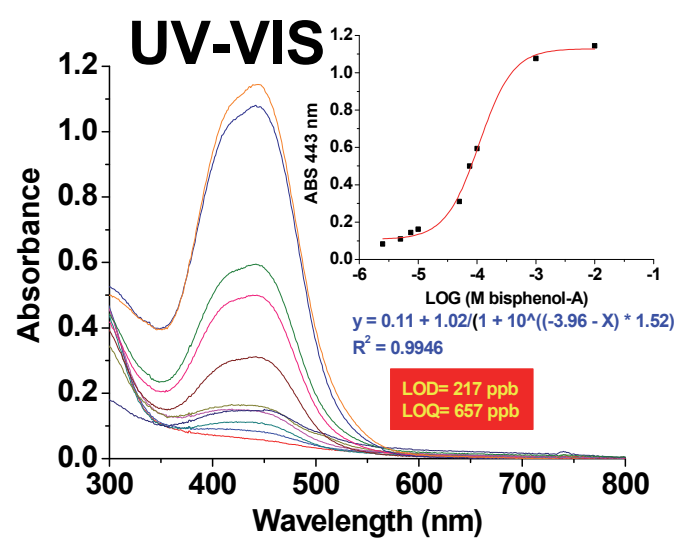

UV-Vis sensors

\begin{tabular}{c|c|c|c}
\hline $\mathbf{R}$ & $\begin{array}{c}\text { Color } \\
\mathbf{G}\end{array}$ & $\mathbf{B}$ & $\begin{array}{c}\text { UV-Vis } \\
\text { Abs (443 nm) }\end{array}$ \\
\hline 132 & 152 & 179 & 0.058 \\
\hline 130 & 150 & 173 & 0.083 \\
\hline 130 & 152 & 167 & 0.110 \\
\hline 131 & 152 & 159 & 0.144 \\
\hline 131 & 151 & 146 & 0.162 \\
\hline 129 & 148 & 116 & 0.146 \\
\hline 129 & 143 & 64 & 0.310 \\
\hline 121 & 141 & 62 & 0.500 \\
\hline 124 & 140 & 49 & 0.593 \\
\hline 123 & 115 & 0 & 1.076 \\
\hline 121 & 122 & 1 & 1.144 \\
\hline
\end{tabular}

c)

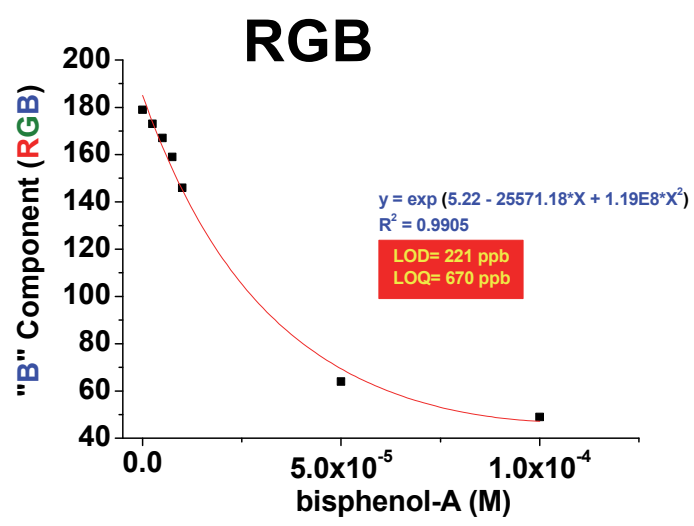

Fig. S8. a) Digital photograph of $\mathbf{F}_{005}$ discs after immersion for $60 \mathrm{~min}$ at RT in aqueous solutions $(\mathrm{NaOH} 0.1 \mathrm{M})$ containing different quantities of bisphenol-A. Data table with the used molar concentrations, RGB parameters obtained from the digital photograph and the absorbance data at the maximum of the color band in the UV-Vis spectra. b) UV-Vis spectra, titration curve of bisphenolA with F005, obtained LOD \& LOQ and the fitting equation. c) Variation of the blue component (RGB) vs the bisphenol-A concentration, obtained LOD \& LOQ and the fitting equation. 
Material suplementario. Capitulo 2 Polymer films containing chemically anchored diazonium salts with long-term stability as colorimetric

a) (Phenol D) 4-chloro-2methylphenol

b)

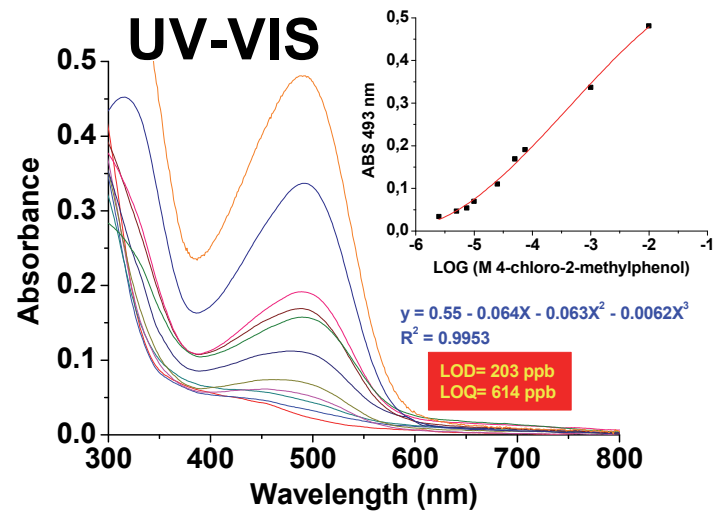

0

$2.50 \times 10^{-6}$

$5.00 \times 10^{-6}$

$7.50 \times 10^{-6}$

$1.00 \times 10^{-5}$

$2.50 \times 10^{-5}$

$5.00 \times 10^{-5}$

$7.50 \times 10^{-5}$

$1.00 \times 10^{-4}$

$1.00 \times 10^{-3}$

$1.00 \times 10^{-2}$
Molar Concentrations

c)

\begin{tabular}{|c|c|c|c|}
\hline R & Color & UV-Vis \\
\hline 132 & G & B & Abs $(\mathbf{4 9 3} \mathbf{n m})$ \\
\hline 131 & 153 & 184 & 0.024 \\
\hline 131 & 150 & 182 & 0.034 \\
\hline 132 & 148 & 182 & 0.047 \\
133 & 146 & 180 & 0.054 \\
\hline 134 & 139 & 175 & 0.110 \\
\hline 135 & 132 & 166 & 0.169 \\
\hline 129 & 122 & 155 & 0.191 \\
\hline 126 & 117 & 148 & 0.157 \\
\hline 121 & 95 & 114 & 0.337 \\
\hline 123 & 87 & 89 & 0.481 \\
\hline
\end{tabular}

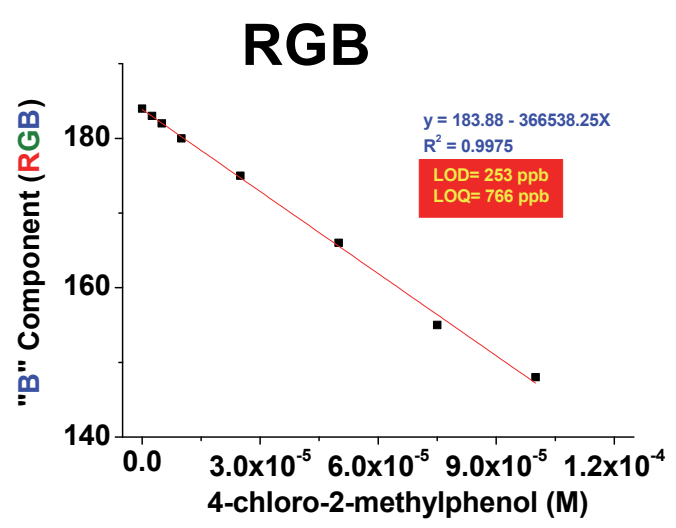

Fig. S9. a) Digital photograph of $F_{005}$ discs after immersion for $60 \mathrm{~min}$ at RT in aqueous solutions $(\mathrm{NaOH} 0.1 \mathrm{M})$ containing different quantities of 4-chloro-2-methylphenol. Data table with the used molar concentrations, RGB parameters obtained from the digital photograph and the absorbance data at the maximum of the color band in the UV-vis spectra. b) UV-Vis spectra, titration curve of phenol D with $F_{005}$, obtained LOD \& LOQ and the fitting equation. c) Variation of the blue component (RGB) vs the 4-chloro-2-methylphenol concentration, obtained LOD \& LOQ and the fitting equation. 
Material suplementario. Capitulo 2 Polymer films containing chemically anchored diazonium salts with long-term stability as colorimetric

a) (Phenol E) 2,4dimethylphenol

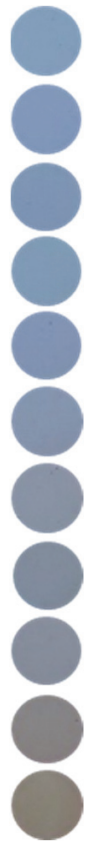

b)

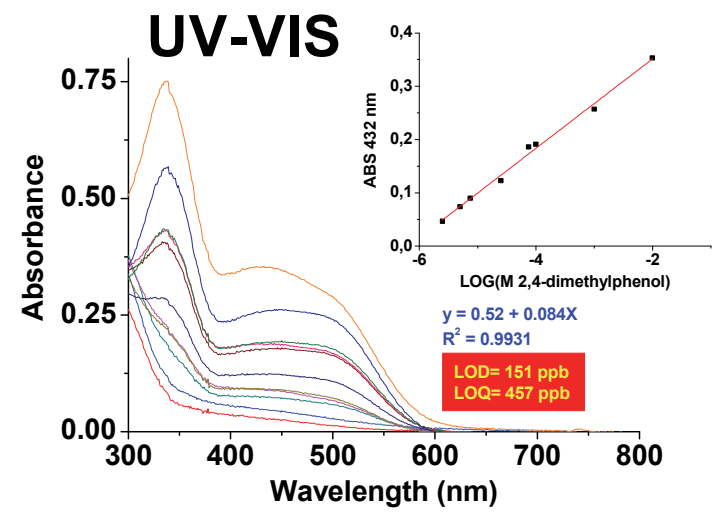

0

$2.50 \times 10^{-6}$

$5.00 \times 10^{-6}$

$7.50 \times 10^{-6}$

$1.00 \times 10^{-5}$

$2.50 \times 10^{-5}$

$5.00 \times 10^{-5}$

$7.50 \times 10^{-5}$

$1.00 \times 10^{-4}$

$1.00 \times 10^{-3}$

$1.00 \times 10^{-2}$
Molar Concentrations

c)

\begin{tabular}{|c|c|c|}
\hline \multicolumn{3}{|c|}{ Color } \\
\hline $\mathbf{R}$ & G & B \\
\hline 128 & 148 & 181 \\
\hline 131 & 151 & 184 \\
\hline 130 & 148 & 175 \\
\hline 129 & 152 & 171 \\
\hline 131 & 146 & 172 \\
\hline 131 & 141 & 161 \\
\hline 129 & 136 & 145 \\
\hline 127 & 122 & 136 \\
\hline 125 & 124 & 128 \\
\hline 120 & 99 & 103 \\
\hline 116 & 95 & 87 \\
\hline
\end{tabular}

UV-Vis sensors Abs $(432 \mathrm{~nm})$

0.028

0.047

0.074

0.090

0.092

0.123

0.177

0.186

0.191

0.257

0.353

\section{RGB}

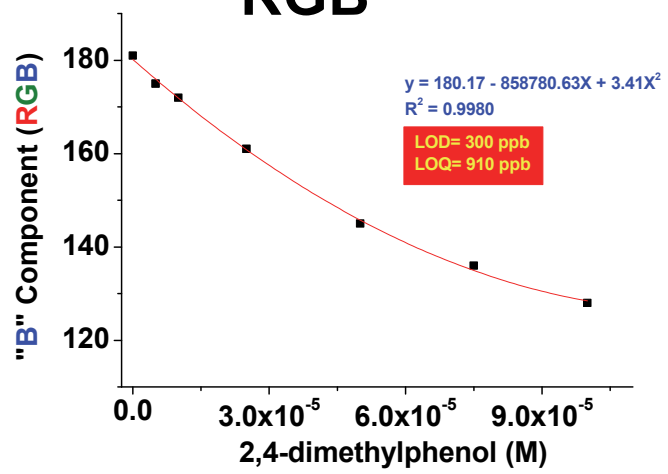

Fig. S10. a) Digital photograph of $F_{005}$ discs after immersion for $60 \mathrm{~min}$ at RT in aqueous solutions $(\mathrm{NaOH} 0.1 \mathrm{M})$ containing different quantities of 2,4-dimethylphenol. Data table with the used molar concentrations, RGB parameters obtained from the digital photograph and the absorbance data at the maximum of the color band in the UV-vis spectra. b) UV-Vis spectra, titration curve of 2,4dimethylphenol with $F_{005}$, obtained LOD \& $L O Q$ and the fitting equation. c) Variation of the blue component $(R G B)$ vs the 2,4-dimethylphenol concentration, obtained LOD \& LOQ and the fitting equation. 
Material suplementario. Capitulo 2 Polymer films containing chemically anchored diazonium salts with long-term stability as colorimetric

a) (Phenol F) 2phenylphenol

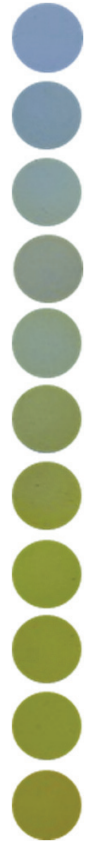

b)

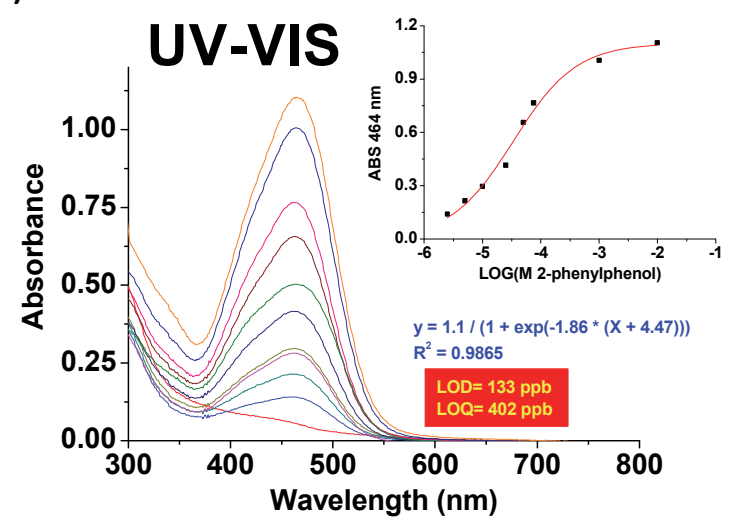

Molar Concentrations

0

$2.50 \times 10^{-6}$

$5.00 \times 10^{-6}$

$7.50 \times 10^{-6}$

$1.00 \times 10^{-5}$

$2.50 \times 10^{-5}$

$5.00 \times 10^{-5}$

$7.50 \times 10^{-5}$

$1.00 \times 10^{-4}$

$1.00 \times 10^{-3}$

$1.00 \times 10^{-2}$

c)
UV-Vis sensors Abs $(464 \mathrm{~nm})$

0.055

0.141

0.215

0.281

0.296

0.415

0.656

0.766

0.503

1.006

1.104

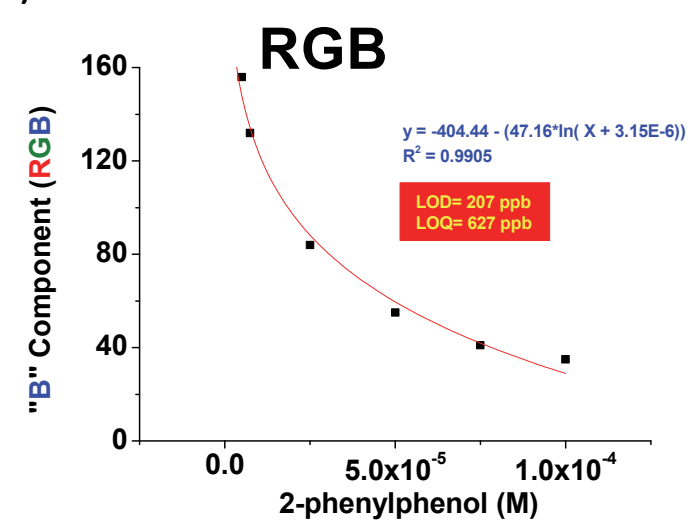

Fig. S11. a) Digital photograph of $F_{005}$ discs after immersion for $60 \mathrm{~min}$ at RT in aqueous solutions $(\mathrm{NaOH} 0.1 \mathrm{M})$ containing different quantities of 2-phenylphenol. Data table with the used molar concentrations, RGB parameters obtained from the digital photograph and the absorbance data at the maximum of the color band in the UV-vis spectra. b) UV-Vis spectra, titration curve of 2phenylphenol with $F_{0005}$, obtained LOD \& LOQ and the fitting equation. c) Variation of the blue component (RGB) vs the 2-phenylphenol concentration, obtained LOD \& LOQ and the fitting equation. 
Material suplementario. Capitulo 2 Polymer films containing chemically anchored diazonium salts with long-term stability as colorimetric

a) (Phenol G) 1-naphthol

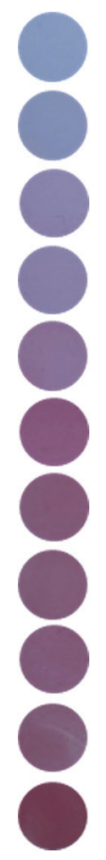

b)

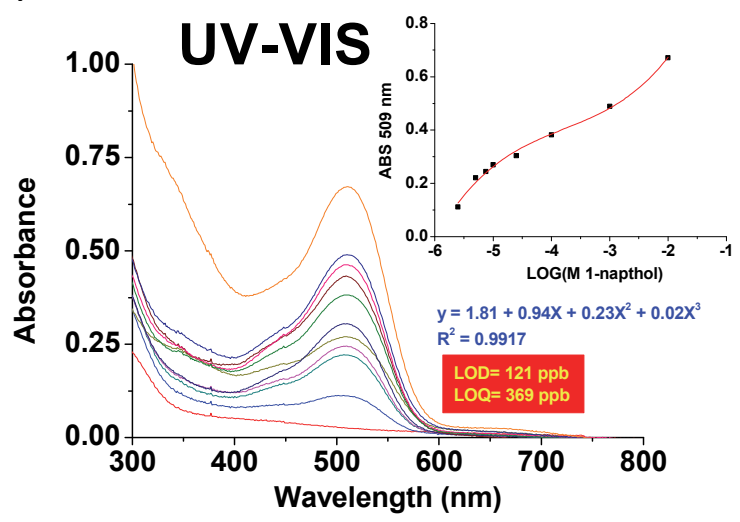

Molar Concentrations

0

$2.50 \times 10^{-6}$

$5.00 \times 10^{-6}$

$7.50 \times 10^{-6}$

$1.00 \times 10^{-5}$

$2.50 \times 10^{-5}$

$5.00 \times 10^{-5}$

$7.50 \times 10^{-5}$

$1.00 \times 10^{-4}$

$1.00 \times 10^{-3}$

$1.00 \times 10^{-2}$

c)

\begin{tabular}{ccc|c}
\hline $\mathbf{R}$ & $\begin{array}{c}\text { Color } \\
\mathbf{G}\end{array}$ & $\mathbf{B}$ & $\begin{array}{c}\text { UV-Vis } \\
\text { Abs }(\mathbf{5 0 9} \mathbf{n m})\end{array}$ \\
\hline 134 & 154 & 189 & 0.026 \\
\hline 136 & 134 & 174 & 0.112 \\
\hline 132 & 115 & 161 & 0.221 \\
\hline 130 & 106 & 152 & 0.245 \\
\hline 129 & 90 & 143 & 0.270 \\
\hline 127 & 65 & 123 & 0.304 \\
\hline 127 & 60 & 112 & 0.433 \\
\hline 125 & 64 & 111 & 0.463 \\
\hline 120 & 59 & 107 & 0.382 \\
\hline 116 & 62 & 97 & 0.489 \\
\hline 108 & 43 & 67 & 0.671 \\
\hline
\end{tabular}

Fig. S12. a) Digital photograph of $F_{005}$ discs after immersion for $60 \mathrm{~min}$ at RT in aqueous solutions $(\mathrm{NaOH} 0.1 \mathrm{M})$ containing different quantities of 1-naphtol. Data table with the used molar concentrations, RGB parameters obtained from the digital photograph and the absorbance data at the maximum of the color band in the UV-vis spectra. b) UV-Vis spectra, titration curve of 1-naphtol with $\mathbf{F}_{\mathbf{0 0 5}}$, obtained LOD \& LOQ and the fitting equation. c) Variation of the blue component (RGB) vs the 1-naphtol concentration, obtained LOD \& LOQ and the fitting equation. 
Material suplementario. Capitulo 2 Polymer films containing chemically anchored diazonium salts with long-term stability as colorimetric

a) (Phenol H) 2,4dinitrophenol

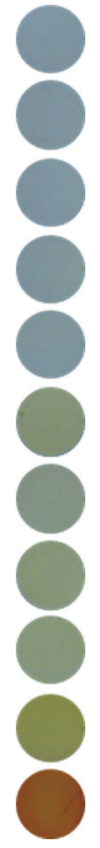

b)

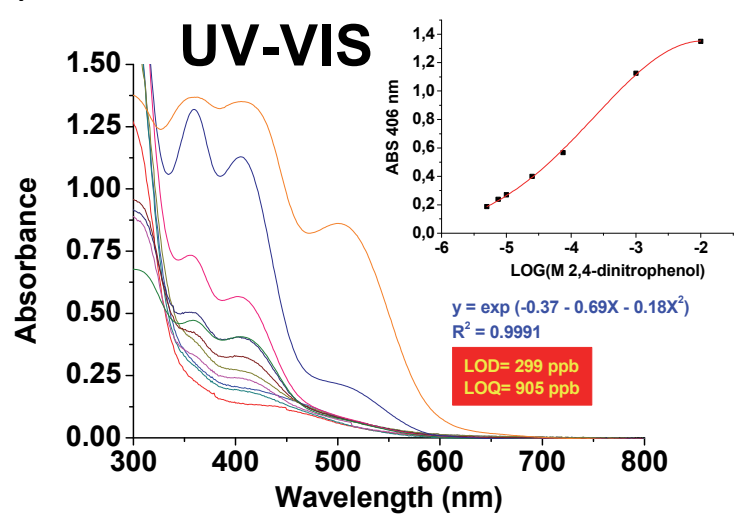

0

$2.50 \times 10^{-6}$

$5.00 \times 10^{-6}$

$7.50 \times 10^{-6}$

$1.00 \times 10^{-5}$

$2.50 \times 10^{-5}$

$5.00 \times 10^{-5}$

$7.50 \times 10^{-5}$

$1.00 \times 10^{-4}$

$1.00 \times 10^{-3}$

$1.00 \times 10^{-2}$
Color

Molar Concentrations

c)

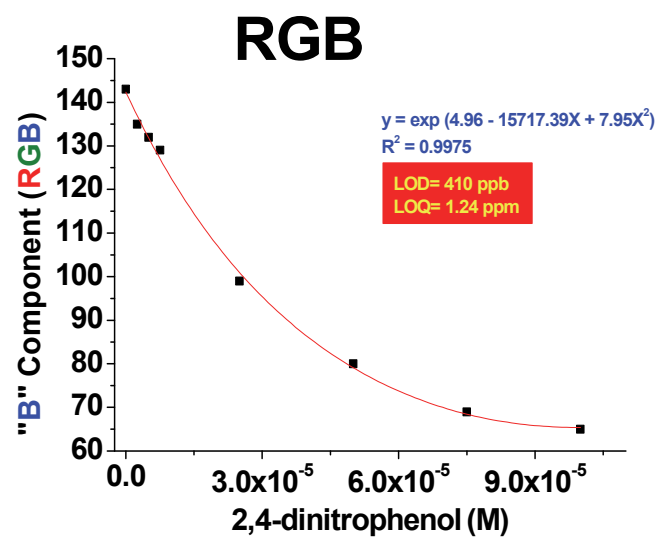

UV-Vis Abs $(406 \mathrm{~nm})$

0.137

0.200

0.188

0.239

0.270

0.400

0.325

0.566

0.407

1.126

1.350 ensors 
Material suplementario. Capitulo 2 Polymer films containing chemically anchored diazonium salts with long-term stability as colorimetric

a) (Phenol I) 4-chlorophenol Molar Concentrations

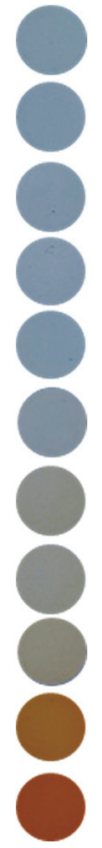

b)

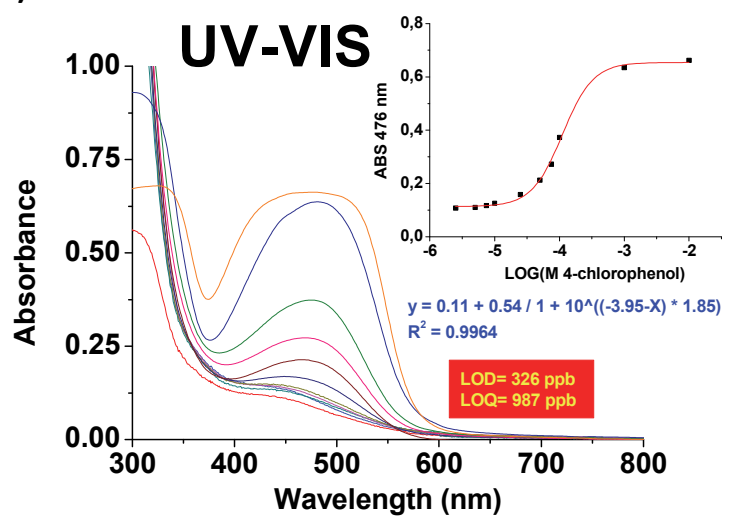

UV-Vis sensors

\begin{tabular}{c|c|c|c}
\hline $\mathbf{R}$ & $\begin{array}{c}\text { Color } \\
\mathbf{G}\end{array}$ & $\mathbf{B}$ & $\begin{array}{c}\text { UV-Vis } \\
\text { Abs }(\mathbf{4 7 6} \mathbf{n m})\end{array}$ \\
\hline 135 & 140 & 145 & 0.089 \\
\hline 133 & 140 & 150 & 0.108 \\
\hline 130 & 136 & 148 & 0.110 \\
\hline 129 & 137 & 152 & 0.117 \\
\hline 131 & 139 & 155 & 0.126 \\
\hline 132 & 135 & 148 & 0.158 \\
\hline 134 & 128 & 139 & 0.212 \\
\hline 135 & 122 & 130 & 0.272 \\
\hline 140 & 118 & 122 & 0.373 \\
\hline 139 & 50 & 22 & 0.635 \\
\hline 136 & 38 & 1 & 0.662 \\
\hline
\end{tabular}

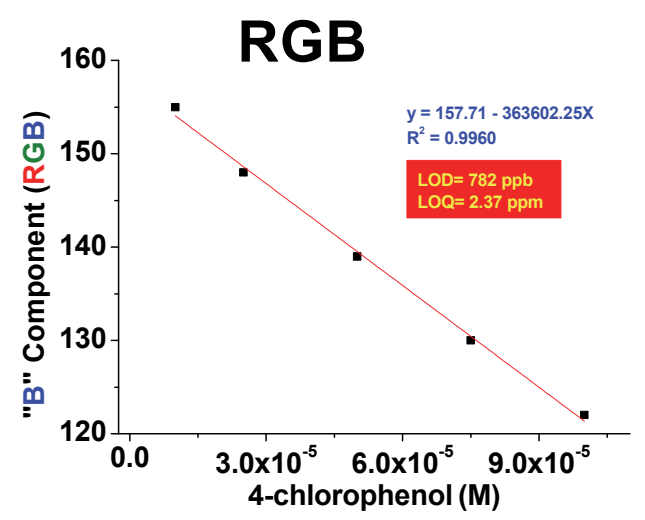

Fig. S14. a) Digital photograph of $F_{025}$ discs after immersion for $60 \mathrm{~min}$ at RT in aqueous solutions $(\mathrm{NaOH} 0.1 \mathrm{M})$ containing different quantities of 4-chlorophenol. Data table with the used molar concentrations, RGB parameters obtained from the digital photograph and the absorbance data at the maximum of the color band in the UV-Vis spectra. b) UV-Vis spectra, titration curve of 4chlorophenol with $\mathbf{F}_{\mathbf{0 2 5}}$, obtained LOD \& LOQ and the fitting equation. c) Variation of the blue component (RGB) vs the 4-chlorophenol concentration, obtained LOD \& LOQ and the fitting equation. 
Material suplementario. Capitulo 2 Polymer films containing chemically anchored diazonium salts with long-term stability as colorimetric

a) (Phenol J) 1,8dihydroxyanthraquinone

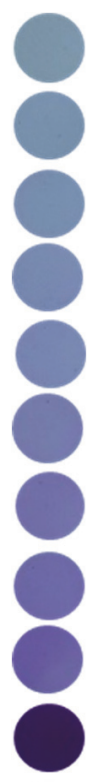

\section{Molar Concentrations}

0

$2.50 \times 10^{-6}$

$5.00 \times 10^{-6}$

$7.50 \times 10^{-6}$

$1.00 \times 10^{-5}$

$2.50 \times 10^{-5}$

$5.00 \times 10^{-5}$

$7.50 \times 10^{-5}$

$1.00 \times 10^{-4}$

$1.00 \times 10^{-3}$

$1.00 \times 10^{-2}$

b)

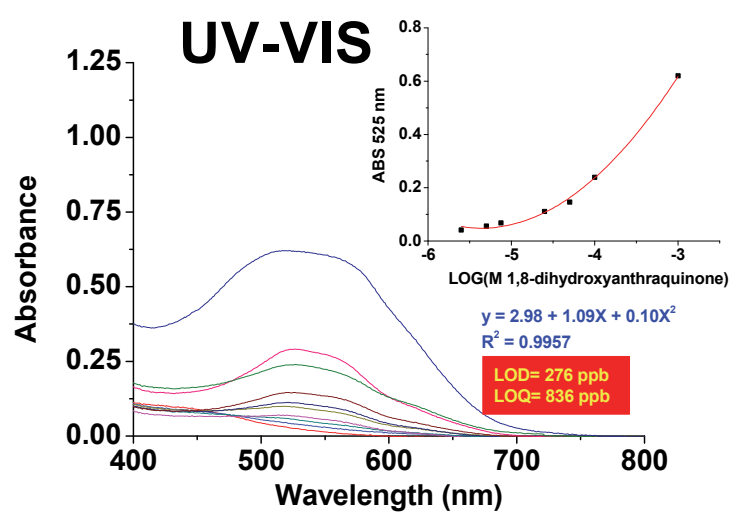

c)
Color

\begin{tabular}{|c|c|c|}
\hline $\mathbf{R}$ & $\mathbf{G}$ & $\mathbf{B}$ \\
\hline 127 & 141 & 154 \\
124 & 140 & 163 \\
122 & 136 & 169 \\
\hline 122 & 134 & 173 \\
\hline 120 & 125 & 173 \\
\hline 114 & 112 & 168 \\
\hline 104 & 93 & 161 \\
\hline 95 & 81 & 153 \\
\hline 80 & 58 & 139 \\
\hline 12 & 1 & 54 \\
\hline- & - & - \\
\hline
\end{tabular}

UV-Vis

Abs (525 nm)

0.026

0.042

0.056

0.078

0.098

0.111

0.146

0.290

0.239

0.620

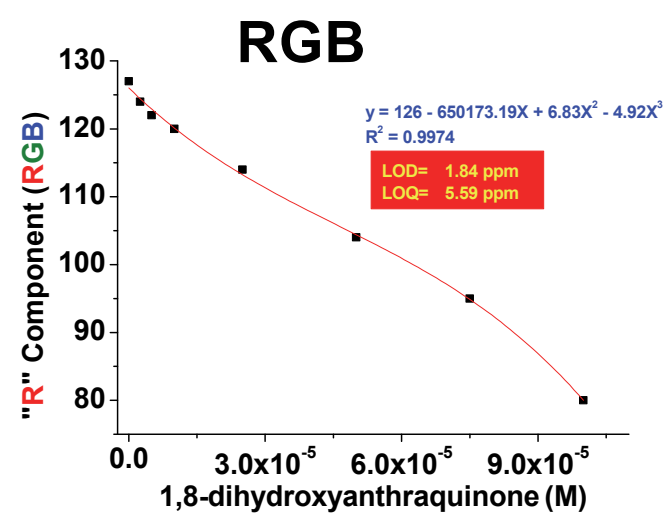

Fig. S15. a) Digital photograph of $F_{025}$ discs after immersion for 60 min at RT in aqueous solutions $(\mathrm{NaOH} 0.1 \mathrm{M})$ containing different quantities of 1,8-dihydroxyanthraquinone. Data table with the used molar concentrations, RGB parameters obtained from the digital photograph and the absorbance data at the maximum of the color band in the UV-vis spectra. b) UV-Vis spectra, titration curve of 1,8dihydroxyanthraquinone with $\mathrm{F}_{025}$, obtained LOD \& LOQ and the fitting equation. c) Variation of the red component (RGB) vs the 1,8-dihydroxyanthraquinone concentration, obtained LOD \& LOQ and the fitting equation. 
Material suplementario. Capitulo 2 Polymer films containing chemically anchored diazonium salts with long-term stability as colorimetric

a) (Phenol K) 2-nitrophenol Molar Concentrations

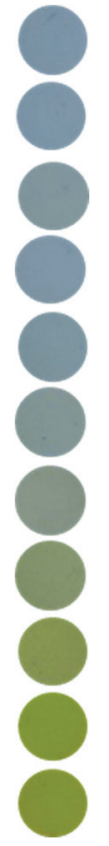

b)

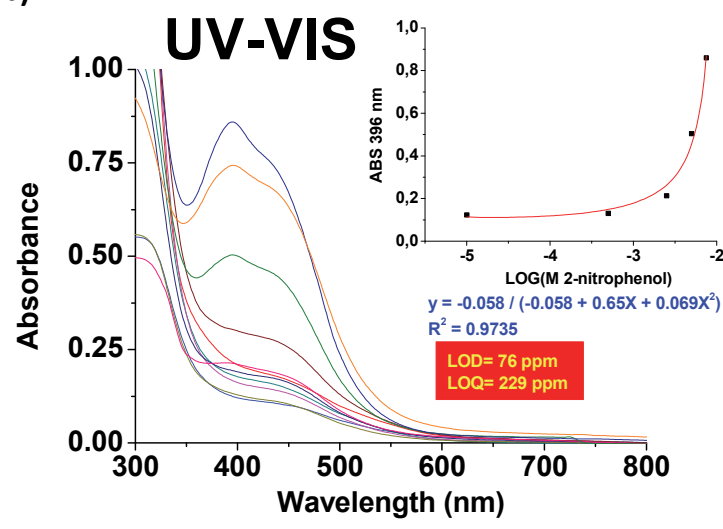

Color

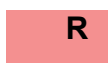

0

$1.00 \times 10^{-5}$

$1.00 \times 10^{-4}$

$2.50 \times 10^{-4}$

$5.00 \times 10^{-4}$

$7.50 \times 10^{-4}$

$1.00 \times 10^{-3}$

$2.50 \times 10^{-3}$

$5.00 \times 10^{-3}$

$7.50 \times 10^{-3}$

$1.00 \times 10^{-2}$

c)
UV-Vis sensors Abs (396 nm)

0.214

0.123

0.188

0.165

0.131

0.192

0.302

0.213

0.504

0.860

0.745

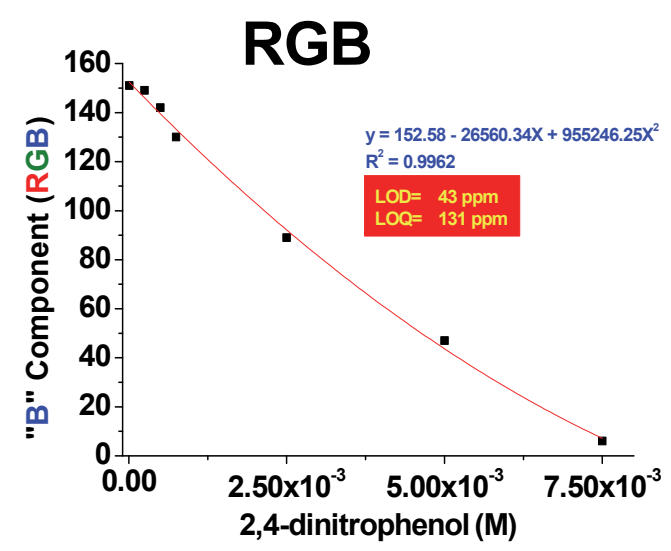

Fig. S16. a) Digital photograph of $\mathbf{F}_{025}$ discs after immersion for $60 \mathrm{~min}$ at $\mathrm{RT}$ in aqueous solutions $(\mathrm{NaOH} 0.1 \mathrm{M})$ containing different quantities of 2-nitrophenol. Data table with the used molar concentrations, RGB parameters obtained from the digital photograph and the absorbance data at the maximum of the color band in the UV-vis spectra. b) UV-Vis spectra, titration curve of 2nitrophenol with $\mathbf{F}_{025}$, obtained LOD \& LOQ and the fitting equation. c) Variation of the blue component $(R G B)$ vs the 2-nitrophenol concentration, obtained LOD \& LOQ and the fitting equation. 
Material suplementario. Capitulo 2 Polymer films containing chemically anchored diazonium salts with long-term stability as colorimetric

a) (Phenol L) fenhexamid

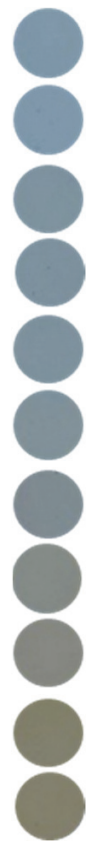

b)

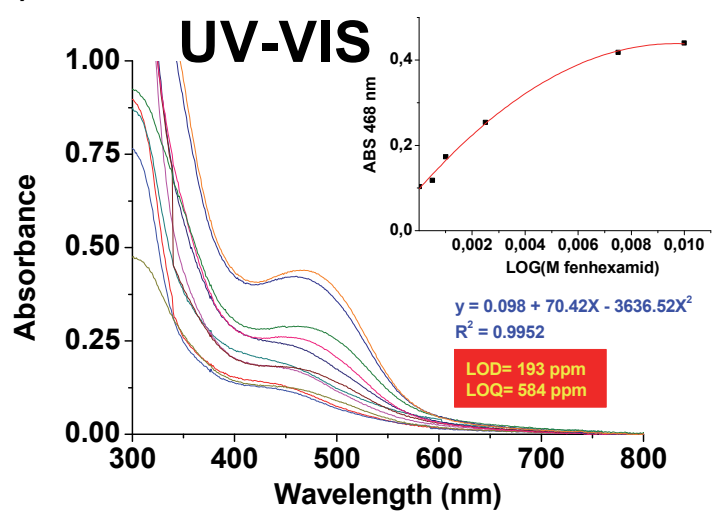

0

$1.00 \times 10^{-5}$

$1.00 \times 10^{-4}$

$2.50 \times 10^{-4}$

$5.00 \times 10^{-4}$

$7.50 \times 10^{-4}$

$1.00 \times 10^{-3}$

$2.50 \times 10^{-3}$

$5.00 \times 10^{-3}$

$7.50 \times 10^{-3}$

$1.00 \times 10^{-2}$

b)
Molar Concentrations

Fig. S17. a) Digital photograph of $\mathbf{F}_{025}$ discs after immersion for $60 \mathrm{~min}$ at RT in aqueous solutions $(\mathrm{NaOH} 0.1 \mathrm{M})$ containing different quantities of fenhexamid. Data table with the used molar concentrations, RGB parameters obtained from the digital photograph and the absorbance data at the maximum of the color band in the UV-vis spectra. b) UV-Vis spectra, titration curve of fenhexamid with $\mathbf{F}_{\mathbf{0 2 5}}$, obtained LOD \& LOQ and the fitting equation. c) Variation of the blue component (RGB) vs the fenhexamid concentration, obtained LOD \& LOQ and the fitting equation.
UV-Vis

\begin{tabular}{c|c|c|c}
\hline $\mathbf{R}$ & $\begin{array}{c}\text { Color } \\
\mathbf{G}\end{array}$ & $\mathbf{B}$ & $\begin{array}{c}\text { UV-Vis } \\
\text { Abs (468 } \mathbf{n m})\end{array}$ \\
\hline 123 & 133 & 139 & 0.112 \\
\hline 122 & 136 & 141 & 0.103 \\
\hline 121 & 132 & 128 & 0.168 \\
\hline 123 & 132 & 137 & 0.162 \\
\hline 124 & 132 & 135 & 0.118 \\
\hline 124 & 128 & 127 & 0.226 \\
\hline 124 & 124 & 128 & 0.173 \\
\hline 121 & 113 & 113 & 0.254 \\
\hline 117 & 100 & 98 & 0.288 \\
\hline 114 & 90 & 77 & 0.418 \\
\hline 115 & 93 & 75 & 0.440 \\
\hline
\end{tabular}

c)

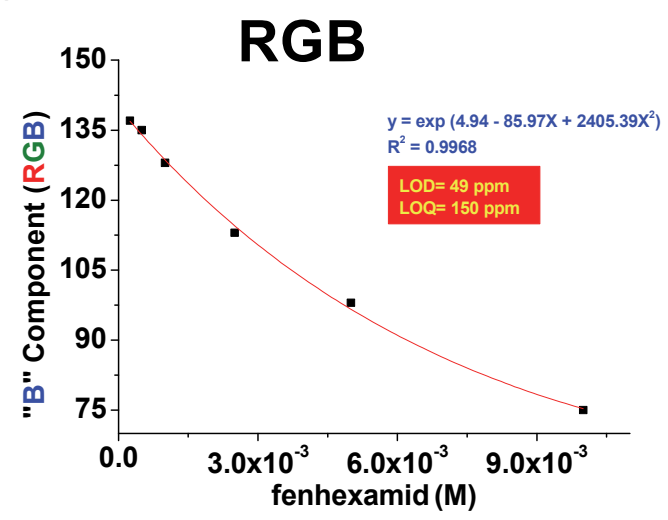


Material suplementario. Capitulo 2 Polymer films containing chemically anchored diazonium salts with long-term stability as colorimetric

a) (Phenol M) 2,4dichlorophenol

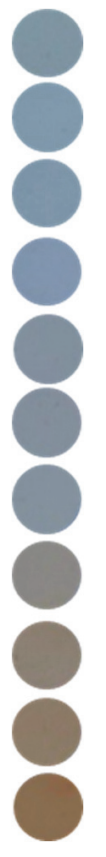

b)

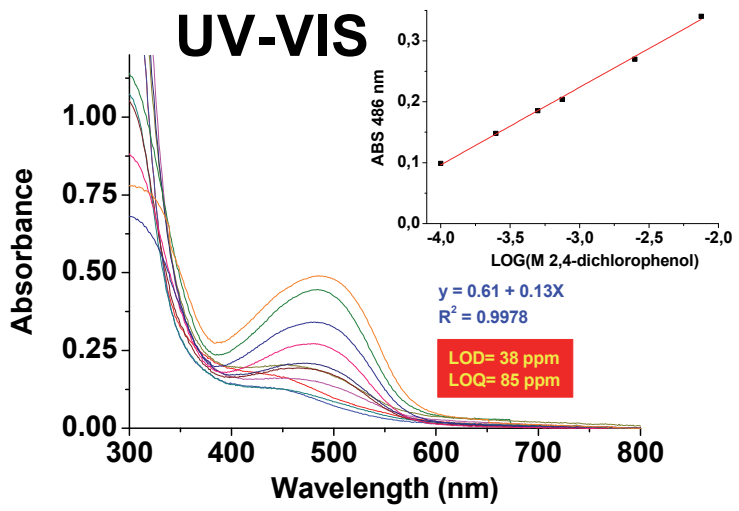

0

$1.00 \times 10^{-5}$

$1.00 \times 10^{-4}$

$2.50 \times 10^{-4}$

$5.00 \times 10^{-4}$

$7.50 \times 10^{-4}$

$1.00 \times 10^{-3}$

$2.50 \times 10^{-3}$

$5.00 \times 10^{-3}$

$7.50 \times 10^{-3}$

$1.00 \times 10^{-2}$
Molar Concentrations

c)

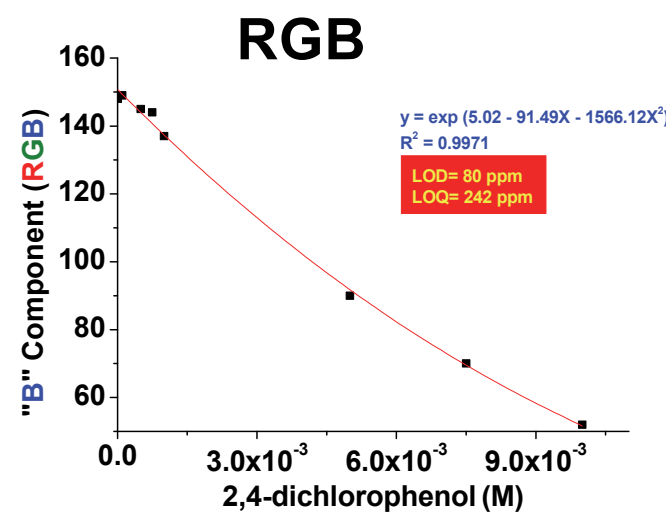

0.118

0.089

0.099

0.148

0.185

0.204

0.185

0.270

0.445

0.340

0.490
UV-Vis sensors

Fig. S18. a) Digital photograph of $F_{025}$ discs after immersion for $60 \mathrm{~min}$ at $\mathrm{RT}$ in aqueous solutions $(\mathrm{NaOH} 0.1 \mathrm{M})$ containing different quantities of 2,4-dichlorophenol. Data table with the used molar concentrations, RGB parameters obtained from the digital photograph and the absorbance data at the maximum of the color band in the UV-Vis spectra. b) UV-Vis spectra, titration curve of 2,4dichlorophenol with $\mathbf{F}_{\mathbf{0 2 5}}$, obtained LOD \& LOQ and the fitting equation. c) Variation of the blue component (RGB) vs the 2,4-dichlorophenol concentration, obtained LOD \& LOQ and the fitting equation. 
Material suplementario capitulo 2 Easy and inexpensive method for the visual and electronic detection of oxidants in air by using vinylic films with embedded aniline

\title{
Easy and inexpensive method for the visual and electronic detection of oxidants in air by using vinylic films with embedded aniline
}

\begin{abstract}
Blanca S. Pascual, ${ }^{\dagger}$ Saúl Vallejos, ${ }^{\dagger}$ José A. Reglero Ruiz, Juan C. Bertolín, ${ }^{\ddagger}$ César Represa, ${ }^{\ddagger}$ Félix C. García, ${ }^{+}$José M. García. ${ }^{\text {* }}$

†Departamento de Química, Facultad de Ciencias, Universidad de Burgos, Plaza de Misael Bañuelos s/n, 09001 Burgos, Spain. E-mail: jmiguel@ubu.es, jareglero@ubu.es. Tel: +34 947258 085; Fax: +34 947258831.

‡Departamento de Ingeniería Electromecánica. Área de Tecnología Electrónica. Escuela Politécnica Superior, Universidad de Burgos, Avda. Cantabria, s/n, 09006, Burgos, Spain.
\end{abstract}

\section{S1. Detection procedure}

\section{S1.1. Quantitative detection of oxidants in air by color change: RGB and UV-Vis}

The experimental setting for the detection of oxidant in air was carried out using sensory discs (diameter: $8 \mathrm{~mm}$ ) of F1a. The discs were attached in the inner face of a plastic cap using a double side adhesive tape, Figure S1a. A set of ten aqueous solutions of each oxidant was prepared: in the case of hydrogen peroxide, the solutions were prepared from commercial $\mathrm{H}_{2} \mathrm{O}_{2}$ (33\% wt aq.) and in the case of chlorine the solutions were prepared from commercial bleach ( $\mathrm{NaClO} 5 \% \mathrm{wt}$ aq.). In both cases ultrapure water was used. The container used to create the oxidant atmosphere was a glass vial of $63.91 \mathrm{ml}$ of volume (Figure S1b, c). A constant volume of $5 \mu \mathrm{l}$ of each solution of the oxidant, freshly prepared, was added in the wall of each vial, as close to the bottom as possible (Figure S1b). Immediately, the vial was covered with the plastic cap with the sensory disc and kept at $30^{\circ} \mathrm{C}$ overnight to avoid that part of the gas phase of the pollutant scape out of the vial. During this time the aqueous solution passed to a gaseous state, thus the oxidant was able to get in contact with the sensory disc and penetrate into the vinylic film to react with the acidic aniline embedded, leading to the formation of the PANI (Figure S1d, e). The oxidant concentrations of each vial are detailed in Table S1.
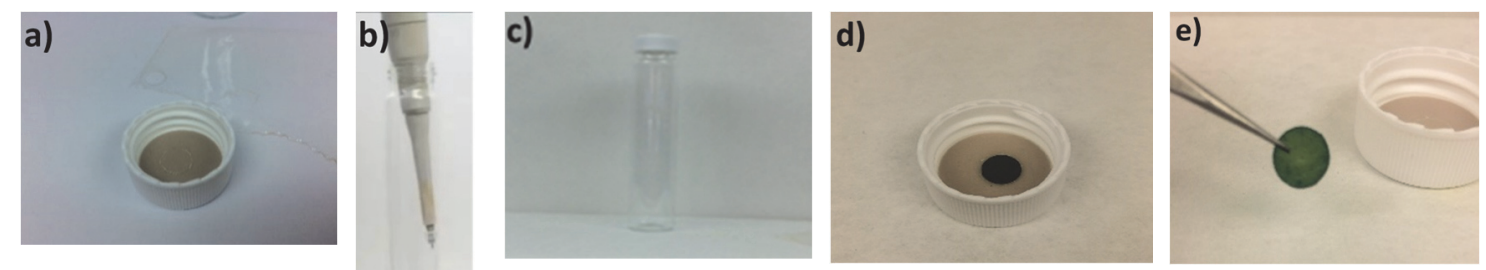

Fig. S1. Experimental procedure to detect oxidant in air with sensory discs of F1a; a) sensory disc (F1a) attached to the cap, with double-side adhesive tape; b) addition of $5 \mu$ l of oxidant solution into the glass vial; c) closed vial with $5 \mu \mathrm{l}$ of the solution of oxidant $\left(\mathrm{H}_{2} \mathrm{O}_{2}\right.$ or $\left.\mathrm{Cl}_{2}\right)$ in the bottom; d) and e) sensory disc, $\mathrm{F}_{\text {PANI, }}$ after exposition to oxidant atmospheres $\left(\mathrm{Cl}_{2}\right.$ in this case). 
Material suplementario capitulo 2

Easy and inexpensive method for the visual and electronic detection of oxidants in air by using

vinylic films with embedded aniline

The quantification of the oxidant in air is carried out using two approaches:

\section{S1.1.1. RGB parameters}

Based on processing a picture taken with a smartphone or digital camera in a retro-illumination homemade light box, see Figure S2.

a)

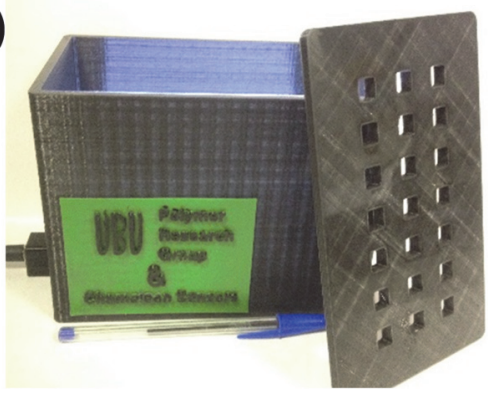

c)

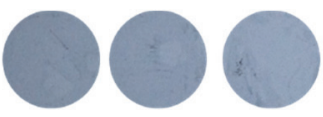

d)
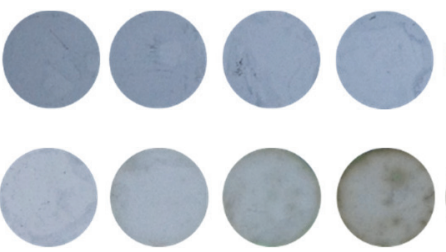
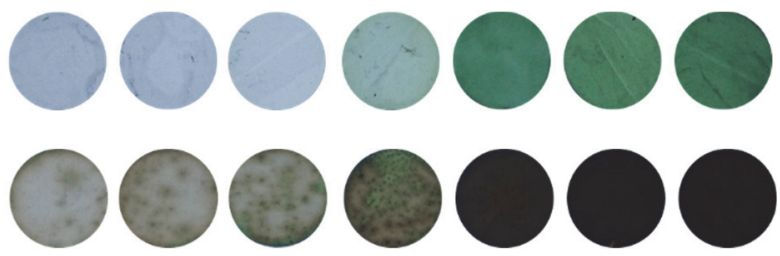

Fig. S2: a) Light box used to take photographs of the discs; b) Interior of the ligth box; c) F1a discs after exposing them to increasing concentration of chlorine in air, $\left[\mathrm{Cl}_{2}\right]: 0$, $16,39,79,118,157,394,787,1180,1574$ ppbv; d) F1a discs after exposing them to increasing concentration of hydrogen peroxide in air, $\left[\mathrm{H}_{2} \mathrm{O}_{2}\right]: 0,35,87,174,261,347$, $868,1737,2605,3474 \mathrm{ppb}_{\mathrm{v}}$.

This device allows us to take pictures in a very reproducible way because of the retroillumination (Figure S2a and S2b). After the oxidant detection, F1a discs were set in a glass which was disposed inside the light box (Figure S2b). The pictures were taken with a smartphone (iPhone $5 S)$.

The RGB colour model is used to display images in electronic systems. The acronym RGB stands for the three-additive primary colours, red $(R)$, green $(G)$ and blue $(B)$. The three RGB values that define each pixel colour range from 0 to 255 and depend on the device used.

The RGB parameters have been obtained using a mobile application called ColorMeter which automatically averages the data of $11 \times 11$ (121) pixels. In this way, a set of three values are associated with each disc: one contribution of red, one of green and one of blue. In order to simplify the data treatment, these values can be treated using principal components analysis (PCA) to yield an only one set of values which corresponds to the first principal component; the software used for carrying out the PCA is Statgraphics. 
Material suplementario capitulo 2

Easy and inexpensive method for the visual and electronic detection of oxidants in air by using vinylic films with embedded aniline

It is possible to create a titration curve relating the first component of the RGB parameters vs the concentration of the oxidant in air as it is shown in Figure S3.

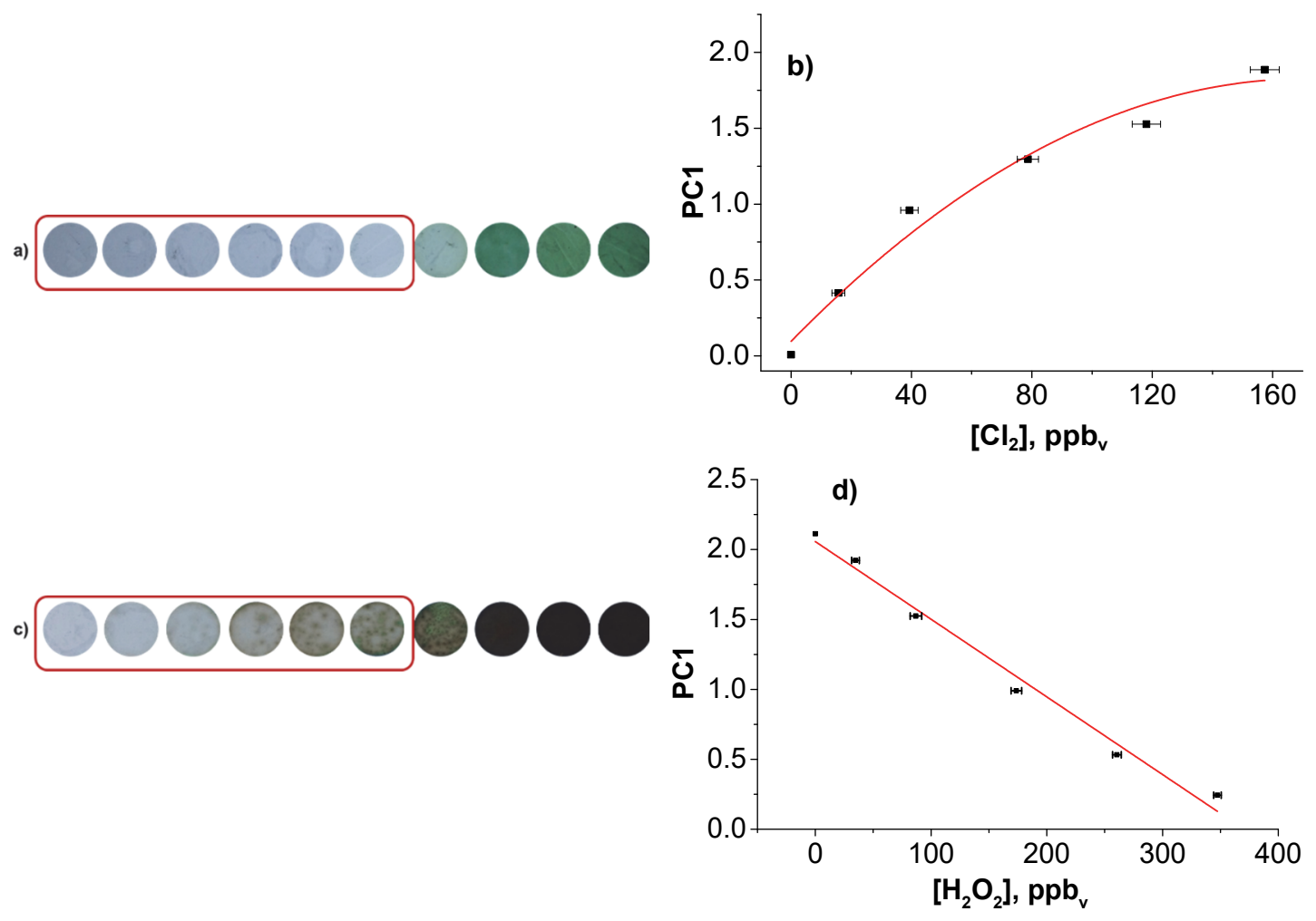

Fig. S3. a) Photograph of the sensory disk (F1a) after exposition to chlorine in air; b) Titration curve of $\mathrm{PC} 1$ vs $\left[\mathrm{Cl}_{2}\right]$ in air; the points used to create the titration curve are the ones inside the rectangle, which correspond to $\left[\mathrm{Cl}_{2}\right]: 0,16,3979,118,157 \mathrm{ppb}_{\mathrm{v}}$; c) Photograph of the sensory discs (F1a) after exposition to hydrogen peroxide in air; d) Titration curve of $\mathrm{PC} 1 \mathrm{vs}\left[\mathrm{H}_{2} \mathrm{O}_{2}\right]$ in air; the points used to create the titration curve are the ones inside the rectangle, which correspond to $\left[\mathrm{H}_{2} \mathrm{O}_{2}\right]: 0,35,87,174,261,347 \mathrm{ppb}_{\mathrm{v}}$. 
Material suplementario capitulo 2

Easy and inexpensive method for the visual and electronic detection of oxidants in air by using

\section{S1.1.2. UV-Vis spectroscopy}

vinylic films with embedded aniline

UV-Vis analysis was performed placing the colored disc inside a crystal recipient, using two magnets to hold the disc in the center of the recipient, to situate the disc exactly in the ray direction and avoid interferences in the measurements.
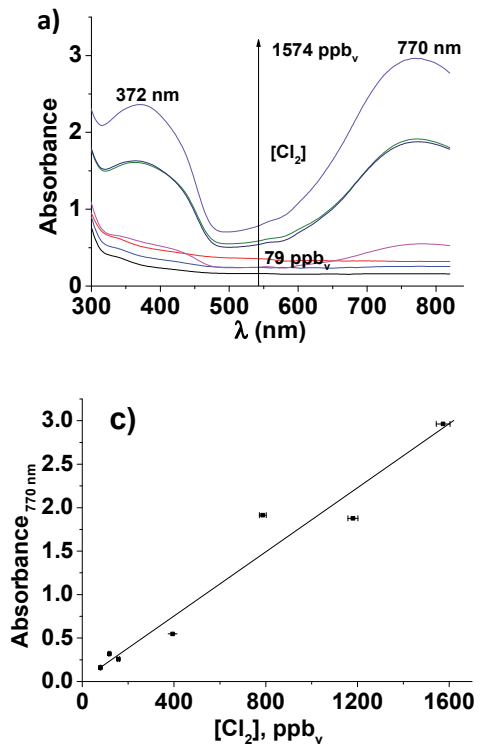
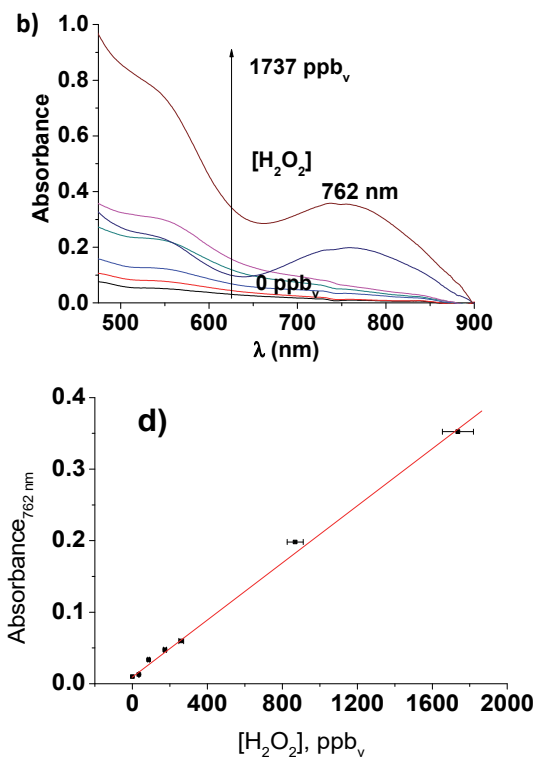

Fig. S4. UV-Vis spectra of the sensory discs after exposing them to increasing concentration of chlorine, (a) and hydrogen peroxide (b) in air and the corresponding titration curves for chlorine (c), [Cl 2 : 79, 118, 157, 394, 787, 1180 and $1574 \mathrm{ppb}_{\mathrm{v}}$; and hydrogen peroxide (d), $\left[\mathrm{H}_{2} \mathrm{O}_{2}\right]: 0,35,87,174,261,868$ and $1737 \mathrm{ppb}_{\mathrm{v}}$.

\section{S1.2. Qualitative detection of oxidants using visual alarm system}

Two pinholes were made to the sensory disc, F1a, to set it between the electrical terminals of the alarm system. The reaction between the chlorine in air and the aniline embedded inside the disc leads to the formation of emeraldine salt, ES, which presents a conductive behaviour acting as a switch closing the electrical circuit and turning on the LED. This system is depicted in Figure S5.
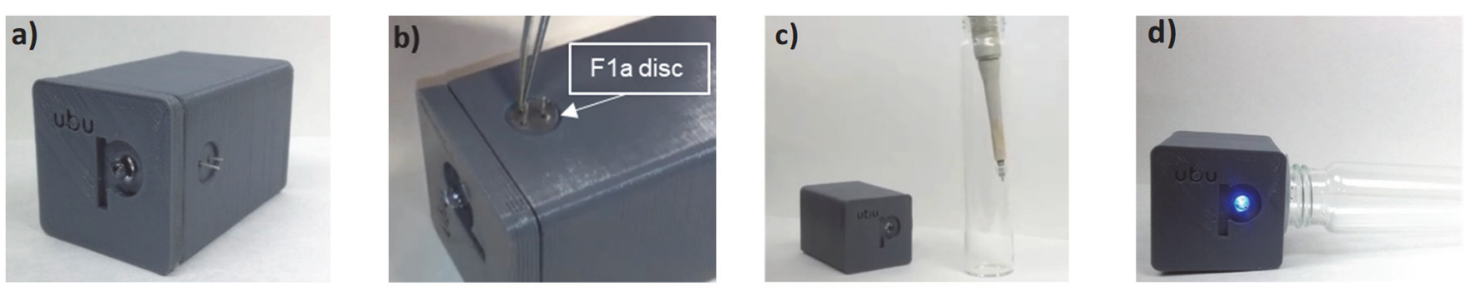

e)
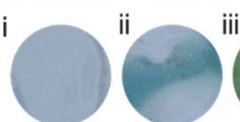

Fig. S5. a) Visual alarm system (3D Printed in polylactic acid); b) Attachment of the sensory disc, F1a, to the metallic terminals; c) Addition of bleach (1 $\mathrm{ppm}_{v} \mathrm{Cl}_{2}$ in air); d) Electrical circuit closed with the sensory disc F1a; e) Evolution of F1a (i), after exposition to chlorine for 1 hour (ii) and for 1 day (iii). 


\section{S1.3. Quantitative detection of chlorine using four-probe/inductive sensor}

Four-point probe sensor. Type JANDEL ${ }^{\circledast}$ cylindrical four-point probe (Fig. S6).
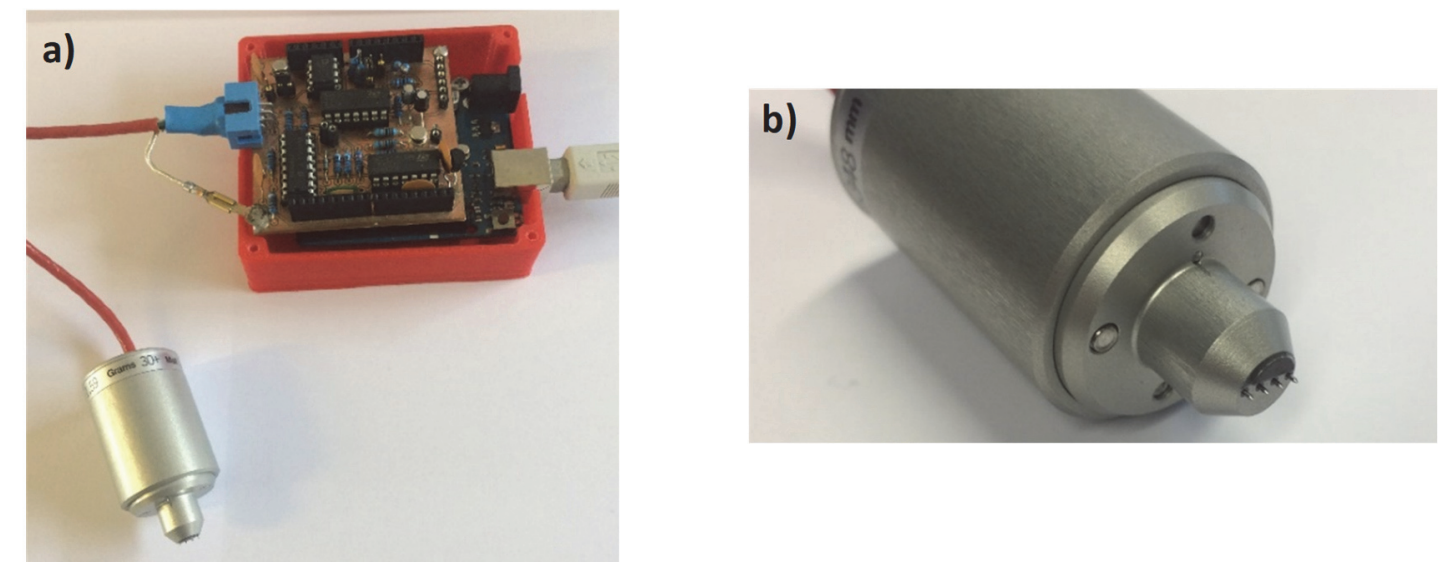

Fig. S6. Four-point probe sensor: a) Detail of the lower board (colour dark blue, commercial microcontroller system Arduino UNO 1) and the upper board (bronze colour, supplementary circuit); b) Detail of the head of the probe, supplied by Jandel®.

Inductive system. This device is based on the inductive coupling that occurs when an alternating current flowing along an inductive coil (primary inductor), also, generates an alternating magnetic field. If a conductive material is invaded by that magnetic field, this field generates in the conductive material, induced currents (Foucault currents). These induced currents depend on the distance, the size and the composition of the conductive material. Foucault currents generate its own magnetic field, which opposes to the original magnetic field of the coil, influencing on the inductive coefficient of the primary inductor. All of this can be reduced to an equivalent electrical circuit basically characterized by two parameters: $L$ and $R_{p}$, as it is show in Figure $S 7$.

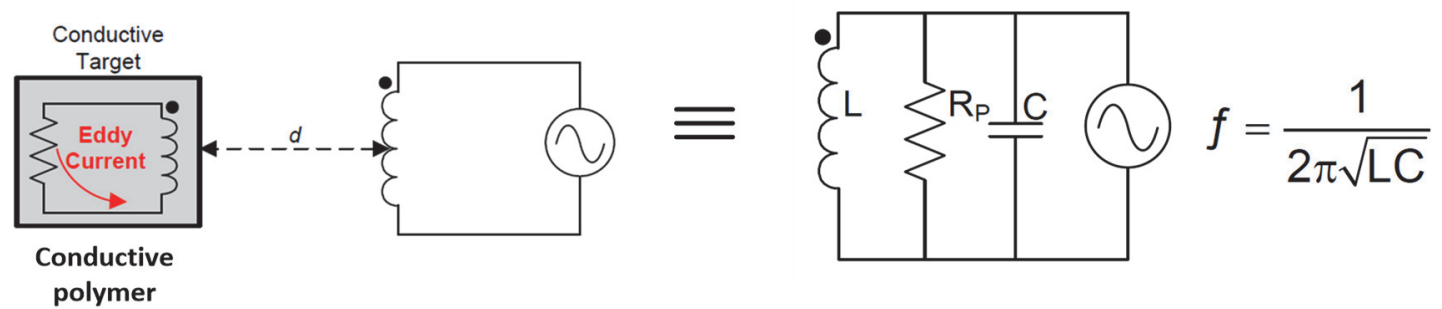

Fig. S7. Scheme of the resulting electronic circuit.

The inductive value $(L)$ and the parallel resistance $\left(R_{p}\right)$ depend on the distance between the primary inductor and the target conductive material (sensory film), and the size and conductivity of the target material. It is possible to register the evolution of the resistivity of the sensory film exposed to an oxidant atmosphere if two conditions are fulfilled: the size of the film does not change during the process, and the relative distance between the primary coil and the film stays constant.

Using this device, it is possible measure the evolution of the process but no absolute values. Thus, it is necessary to use the four-point probe sensor to take the initial and the final values of resistivity of the sensory film. The data obtain with the four-point probe sensor are combined with 
Material suplementario capitulo 2

Easy and inexpensive method for the visual and electronic detection of oxidants in air by using vinylic films with embedded aniline the data obtained with the inductive system, providing reliable values of the evolution of resistivity of the material.

The inductive system has two main parts: the inductive sensor (coil) and the electronic board (inductance to digital converter), as seen in Figure S8.
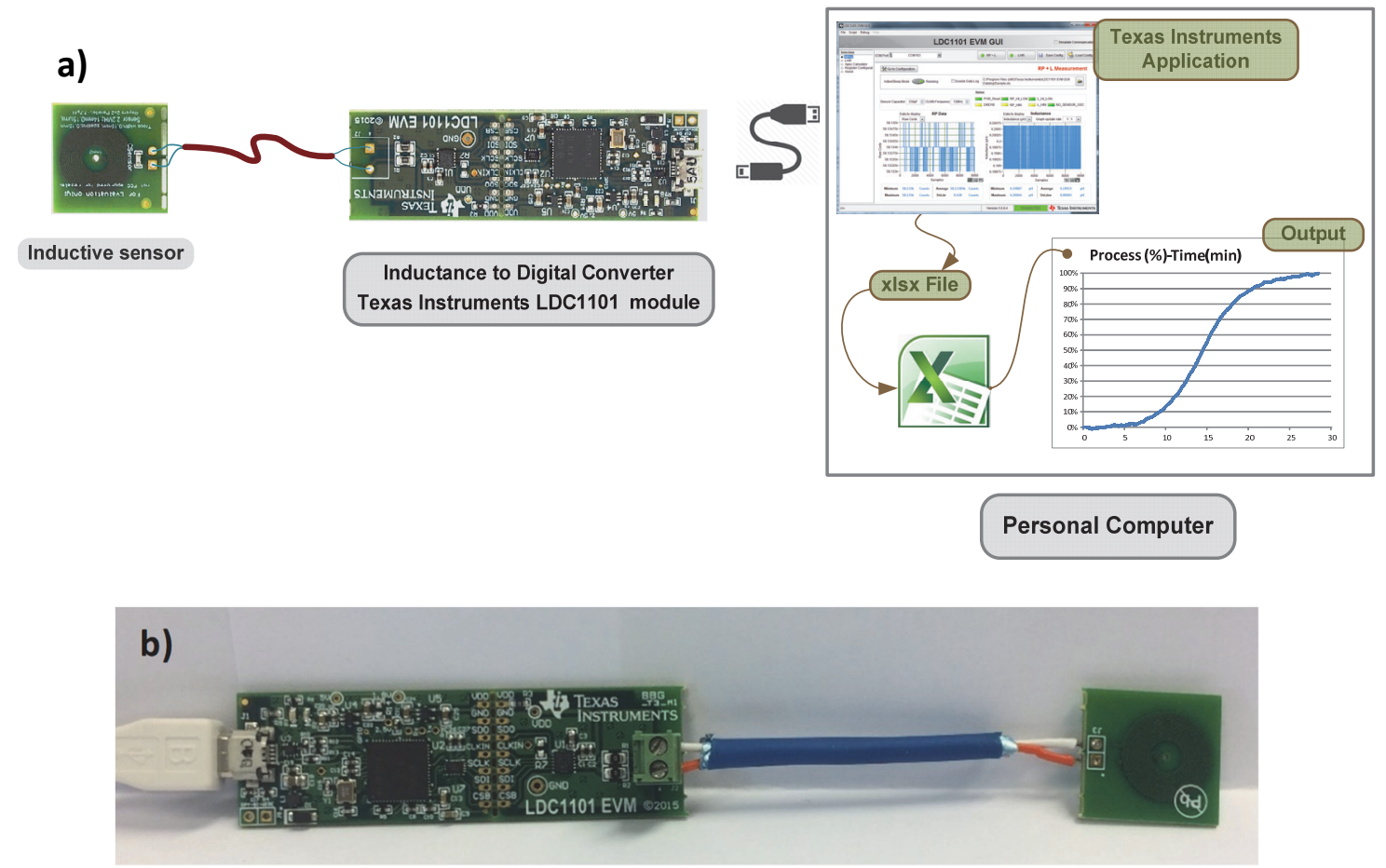

Fig. S8. a) Scheme of the inductive system, and data processing; b) Photograph of the inductive system: the inductive sensor (coil) is connected to the electronic board with a coaxial wire and a strip with screws; The electronic board is connected to the PC by a USB port.

The electronic board is divided in two sections:

- LDC1101 section converts the analogic values of inductance and resistance of the sensor into digital information.

- MPS430 section allows the transfer of the digital information by an USB port.

The output of this inductive system gives relative values of the resistivity of the sensory film (F2a). Using the inductive sensor, the contact between the inductive sensor and the film is not necessary, eliminating the problems associated with bad contact or degradation of the sensory film.

It is very important to fix the inductive sensor to avoid any external vibration, due to the high sensitivity of the system to distance variations between the film and the coil board.

The variations of the resistance of the sensory film (F2a) have been measured with the two systems explained above. Experimentally, a piece of $\mathrm{F} 2 \mathrm{a}$ is attached to a glass. The sensor coil is disposed under this glass and fixed with tape to avoid any movement or vibration during the experiment. The oxidant atmosphere is created using a watch glass which creates a close space with the sensory film. The oxidant agent is chlorine, so commercial bleach is used in form of little 
Material suplementario capitulo 2

Easy and inexpensive method for the visual and electronic detection of oxidants in air by using

vinylic films with embedded aniline

droplets in the inner surface of the watch glass. A volume of $100 \mu$ is added giving a $\left[\mathrm{Cl}_{2}\right]$ of 230 $\mathrm{ppm}_{\mathrm{v}}$, as seen in Figure S9.
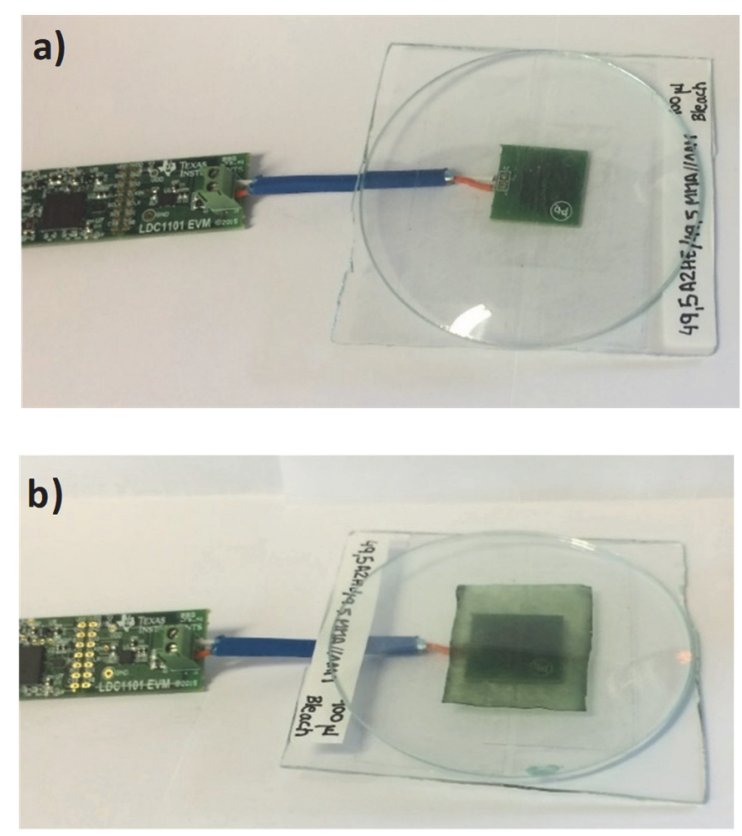

Fig. S9. Experimental setting for the measurements with the inductive sensor, using F2a, dimensions $3 \times 4 \mathrm{~cm}^{2}$; a) Initial appearance of the film before the experiment; b) Final appearance of the film with the emeraldine salt (ES) polymerized.

Figure S10 represents the experimental procedure to carry out the measurements using the fourpoint probe sensor.
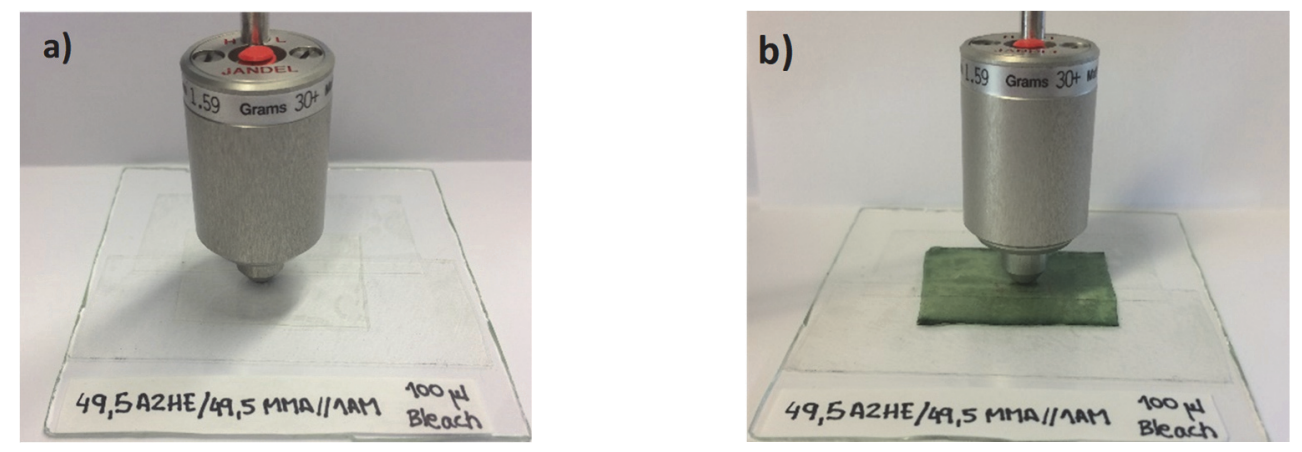

Fig. S10. Experimental procedure using the four-point probe when the film F2a is exposed to chlorine in air, $\left[\mathrm{Cl}_{2}\right]: 230 \mathrm{ppm}_{\mathrm{v}}$ : a) Initial measurement of $\mathbf{F 2 a}$ charged with aniline before exposition; b) Final measurement with the aniline polymerized due to the oxidant atmosphere, changing color from yellowish (aniline) to green (emeraldine salt). 
Material suplementario capitulo 2 Easy and inexpensive method for the visual and electronic detection of oxidants in air by using vinylic films with embedded aniline

\section{S2. Principal component analysis data}

Table S1. Aqueous solutions of the oxidants, in ultrapure water, and the estimated concentration of each oxidant in the flask

$\begin{array}{ccc}\text { Vial number } & \begin{array}{c}\mathrm{ppb}_{v}, \mathrm{Cl}_{2}, \\ \mathrm{mg} / \mathrm{L}\end{array} & \begin{array}{c}\mathrm{ppb}_{v}, \mathrm{H}_{2} \mathrm{O}_{2}, \\ \mathrm{mg} / \mathrm{L}\end{array} \\ \mathbf{1} & 0.0 & 0.0 \\ \mathbf{2} & 15.7 & 34.7 \\ \mathbf{3} & 39.3 & 86.8 \\ \mathbf{4} & 78.7 & 173.7 \\ \mathbf{5} & 118.0 & 260.5 \\ \mathbf{6} & 157.4 & 347.4 \\ \mathbf{7} & 393.5 & 868.4 \\ \mathbf{8} & 786.9 & 1736.8 \\ \mathbf{9} & 1180.4 & 2605.2 \\ \mathbf{1 0} & 1573.9 & 3473.6\end{array}$

Table S2. RGB parameters and PCA values obtained for the detection of $\mathrm{H}_{2} \mathrm{O}_{2}$ at different concentrations.

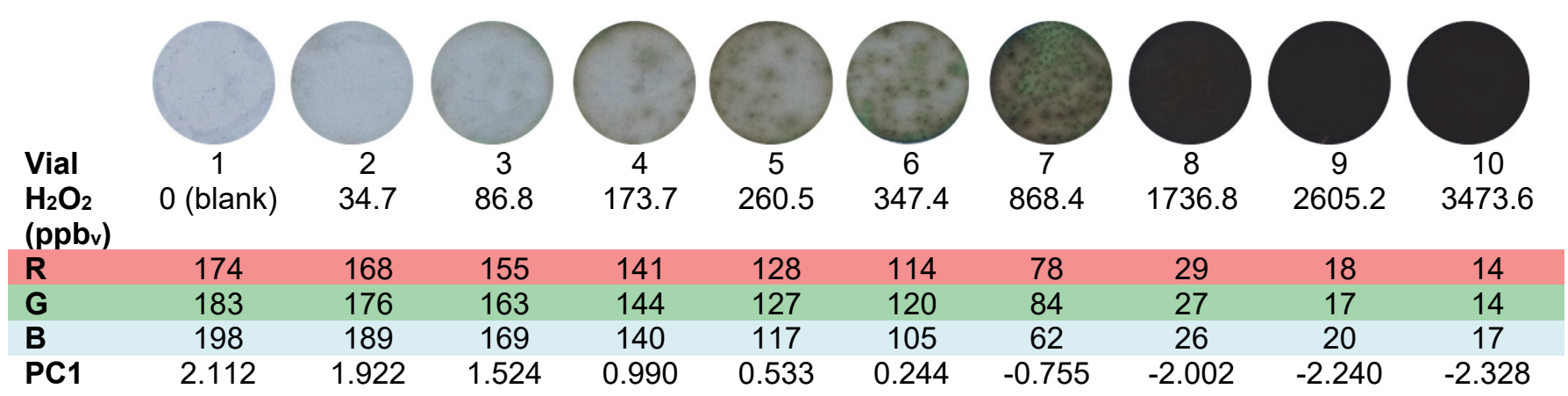

Table S3. RGB parameters and PCA value obtained for the detection of $\mathrm{Cl} 2$ at different concentrations.

\begin{tabular}{|c|c|c|c|c|c|c|c|c|c|c|}
\hline $\begin{array}{c}\mathrm{Vlal}_{2} \\
\mathrm{Cl}_{2}\end{array}$ & 0 (blank) & $\begin{array}{c}2 \\
15.7\end{array}$ & $\begin{array}{c}3 \\
39.3\end{array}$ & $\begin{array}{c}4 \\
78.7\end{array}$ & $\begin{array}{c}5 \\
118.0\end{array}$ & $\begin{array}{c}6 \\
157.4\end{array}$ & 393.5 & $\begin{array}{c}8 \\
786.9\end{array}$ & $\begin{array}{c}9 \\
1180.4\end{array}$ & $\begin{array}{c}10 \\
1573.9\end{array}$ \\
\hline R & 132 & 140 & 150 & 156 & 160 & 167 & 143 & 54 & 63 & 44 \\
\hline G & 143 & 151 & 163 & 170 & 175 & 184 & 173 & 123 & 129 & 109 \\
\hline B & 162 & 173 & 186 & 195 & 201 & 207 & 171 & 95 & 91 & 74 \\
\hline PC1 & 0.007 & 0.414 & 0.959 & 1.295 & 1.527 & 1.886 & 0.924 & -2.176 & -1.977 & -2.859 \\
\hline
\end{tabular}




\section{S3. FTIR analysis of the films}

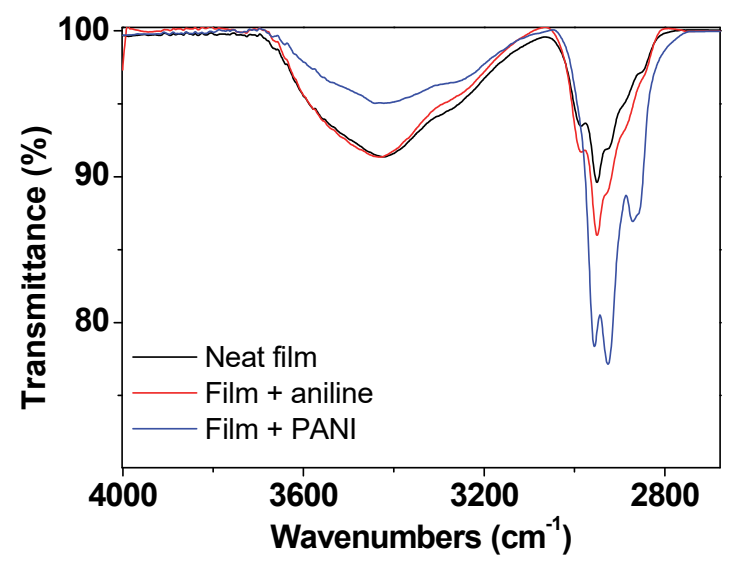

Fig. S11. FTIR spectra of the sensory film; Neat film (with no aniline), Film + aniline (charged with aniline) and Film + PANI (after the exposition to $3.12 \mathrm{ppm}$ of $\mathrm{Cl}_{2}$ ).

\section{S4. SEM micrographs of the surface of the films}
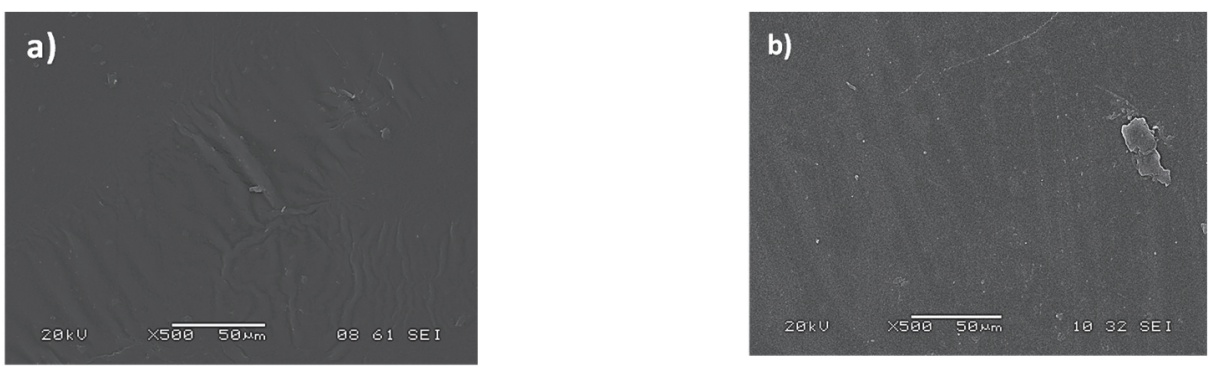

Fig. S12. SEM micrographs of the surface of the films (bar scale $50 \mu m$ ). a) Film F1a; b) Film F2a.

\section{S5. Interference studies}

Table S4. RGB parameters of the pictures of the discs exposed to different oxidants at fixed concentration of $786 \mathrm{ppb}_{\mathrm{v}}$.

\begin{tabular}{|c|c|c|c|c|c|c|c|c|}
\hline Oxidant & $\mathrm{CO}_{2}$ & $\mathrm{O}_{2}$ & $\mathbf{N}_{2}$ & $\mathrm{O}_{3}$ & $\mathrm{SO}_{2}$ & $\mathrm{NO}_{2}$ & $\mathrm{H}_{2} \mathrm{O}_{2}$ & $\mathrm{Cl}_{2}$ \\
\hline $\mathbf{R}$ & 172 & 162 & 173 & 165 & 161 & 159 & 71 & 54 \\
\hline $\mathbf{G}$ & 145 & 128 & 132 & 133 & 137 & 129 & 81 & 123 \\
\hline B & 161 & 151 & 154 & 152 & 157 & 156 & 59 & 95 \\
\hline
\end{tabular}




\section{Microcellular foamed aromatic polyamides (aramids). Structure, thermal and mechanical properties}

Blanca S. Pascual, ${ }^{1}$ Miriam Trigo-López, ${ }^{1}$ Cipriano Ramos, ${ }^{2}$ María Teresa Sanz, ${ }^{2}$ Jesús L. Pablos, ${ }^{3}$ Félix C. García, ${ }^{1}$ José A. Reglero Ruiz ${ }^{1}$ and José Miguel García ${ }^{1}$

1 Departamento de Química, Facultad de Ciencias, Universidad de Burgos, Plaza de Misael Bañuelos s/n, 09001 Burgos, Spain. Tel: +34 947258 085; Fax: +34 947258831.

2 Departamento de Biotecnología y Ciencia de los Alimentos, Área de Ingeniería Química, Facultad de Ciencias, Universidad de Burgos, Plaza de Misael Bañuelos s/n, 09001 Burgos, Spain. Tel: +34 947258 085; Fax: +34 947 258831.

3 Instituto de Ciencia y Tecnología de Polímeros, Consejo Superior de Investigaciones Científicas, ICTP-CSIC, Juan de la Cierva 3, 28006 Madrid, Spain.

\section{S1. Additional results}

\section{S1.1. Determination of glass transition temperatures from DSC curves}

Figure S1 presents the DSC curves of F_PA1, F_PA2, the crosslinked F_PA2 and the ionic liquid 1-allyl-3-methylimidazolium chloride. The transition of the ionic liquid at $50{ }^{\circ} \mathrm{C}$ corresponds to the melting peak of the 1-allyl-3-methylimidazolium chloride. On the other hand, glass transition temperatures of F_PA1 and F_PA2 are clearly observed around $280^{\circ} \mathrm{C}$, with no great differences between both polyamides. Concerning the crosslinked F_PA2, it has been reported in the previous work of Trigo-López et al. [ $\left.{ }^{2}\right]$ that crosslinking can be detected as an endothermic transition during the cooling ramp, around $210^{\circ} \mathrm{C}$, but for larger proportions of azide group $(10 \%$ wt.). In our case, due to the small proportion of azide (1\% wt.), this transition was not observed. In addition, the crosslinked polyamide PA2 did not show a clear glass transition temperature around $280^{\circ} \mathrm{C}$, but only a weak glass transition around $300^{\circ} \mathrm{C}$.

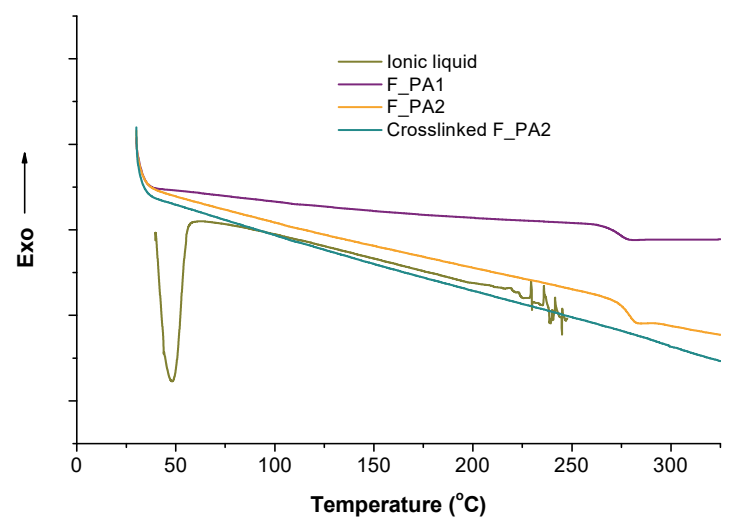

Fig. S1. DSC analysis of F_PA1, F_PA2, crosslinked F_PA2 and the ionic liquid. 
Material suplementario. Capitulo 3 Microcellular foamed aromatic polyamides (aramids). Structure, thermal and mechanical properties

The effect of the addition of the ionic liquid is clearly visible in Figure S2, in which the DSC curves of F_PA1, F_50PA1/50IL and F_50PA1/50IL-R are presented. It is observed that adding the ionic liquid leads to a remarkable plasticization effect, reducing the glass transition temperature down to around $85^{\circ} \mathrm{C}$, in which a clear endothermic is observed (F_50PA1/50IL). The film without the ionic liquid (F_50PA1/50IL-R), presents a very similar behavior to the one of the F_PA1, with a glass transition temperature close to $275^{\circ} \mathrm{C}$.

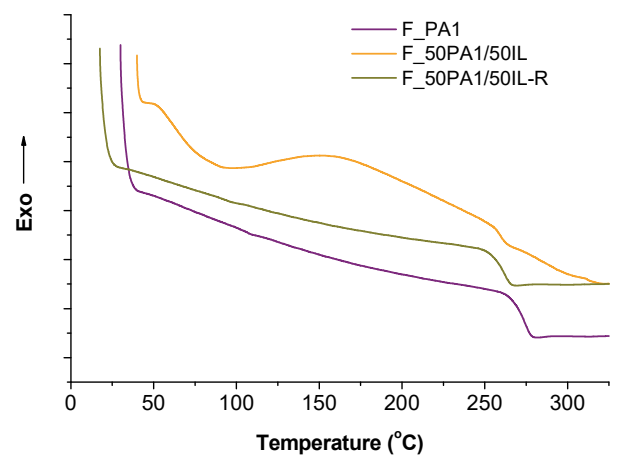

Fig. S2. DSC analysis of F_PA1, F_50PA1/50IL and F_50PA1/50IL-R.

\section{S1.2 TGA measurements}

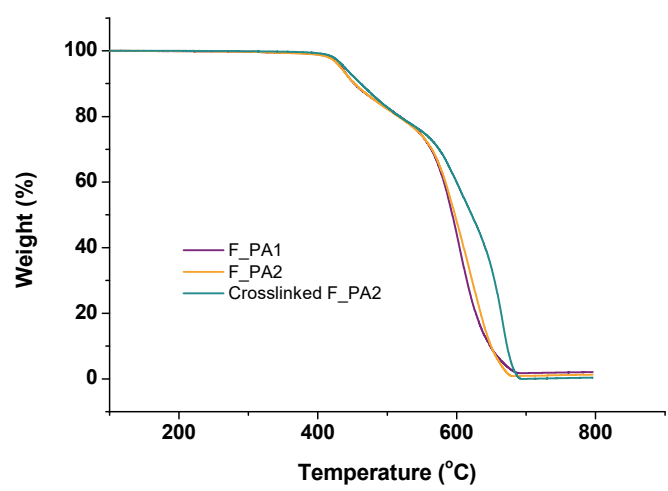

Fig. S3. TGA curves of F_PA1, F_PA2 and crosslinked F_PA2.

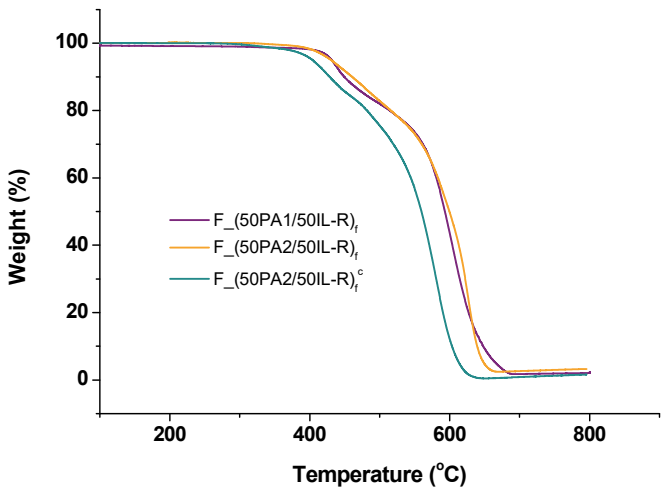

Fig. S4. TGA curves of $F \_(50 P A 1 / 50 I L-R) f$, $F_{-}(50 P A 2 / 50 I L-R)_{f}$ and $F_{-}^{-}(50 P A 2 / 50 I L-R)_{f}^{c}$. 
Material suplementario. Capitulo 3 Microcellular foamed aromatic polyamides (aramids). Structure, thermal and mechanical

\section{S1.3 Stress-strain curves}
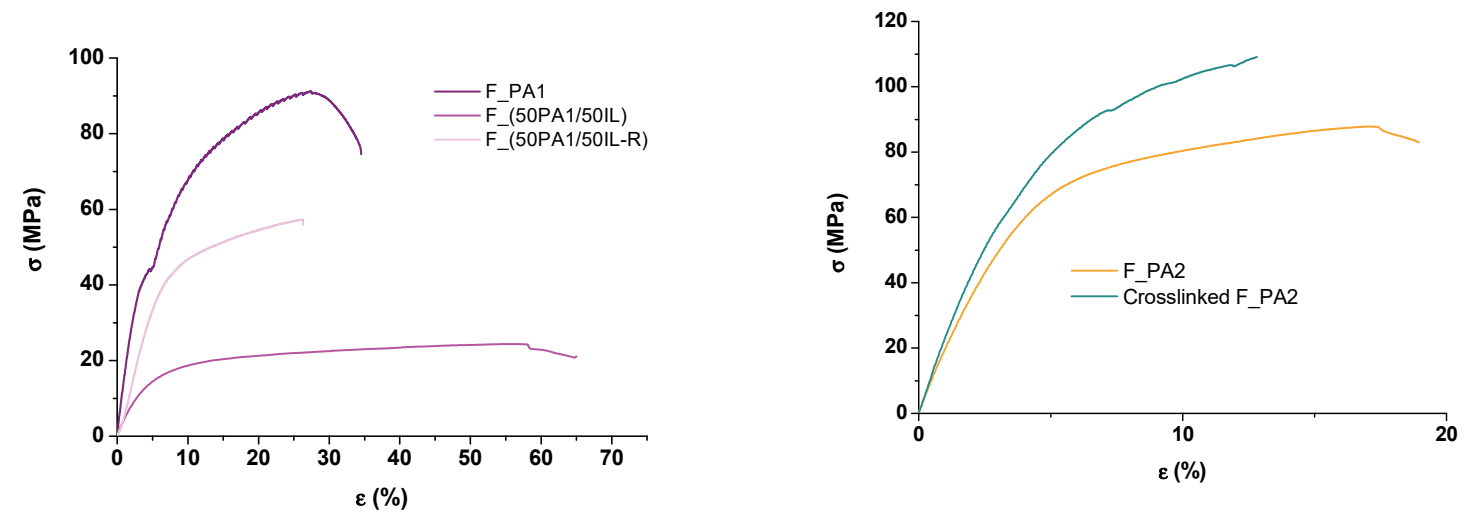

Fig. S5. Stress-strain curves of $F P A 1$, F_(50PA1/50IL) and F_(50PA1/50̄IL-R).

Fig. S6. Stress-strain curves of F_PA2 and crosslinked F_PA2.

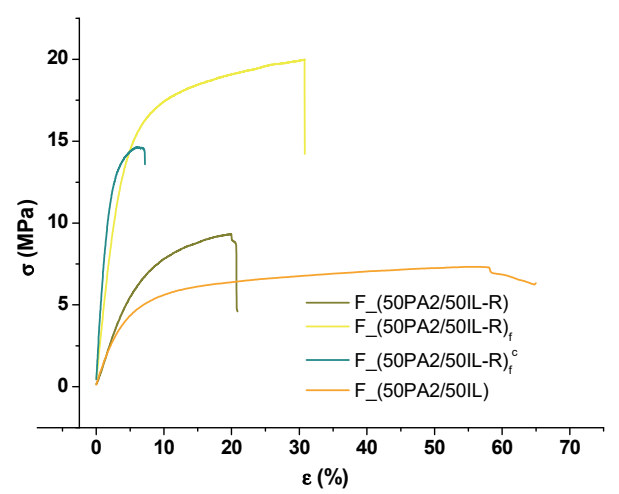

Fig. S7. Stress-strain curves of F_(50PA2/50IL), F_(50PA2/50IL-R), F_(50PA2/50IL-R)f, and F_(50PA2/50IL-R) $)^{\mathrm{c}}$. 


\section{Porous aromatic polyamides the easy and green way}

Blanca S. Pascual, ${ }^{1}$ Miriam Trigo-López, ${ }^{1}$ José A. Reglero Ruiz, ${ }^{* 1}$ Jesús L. Pablos, ${ }^{2}$ Juan C. Bertolín, ${ }^{3}$ César Represa, ${ }^{3}$ José V. Cuevas, ${ }^{1}$ Félix C. García, ${ }^{1}$ and José M. García ${ }^{* 1}$

\footnotetext{
1 Departamento de Química, Facultad de Ciencias, Universidad de Burgos, Plaza de Misael Bañuelos s/n, 09001 Burgos, Spain. Tel: +34 947258 085; Fax: +34 947258831.

${ }^{2}$ Instituto de Ciencia y Tecnología de Polímeros, Consejo Superior de Investigaciones Científicas, ICTP-CSIC, Juan de la Cierva 3, 28006 Madrid, Spain. Tel: +34 915622 900; Fax: +34 915644583.

${ }^{3}$ Departamento de Ingeniería Electromecánica, Área de Tecnología Electrónica, Escuela Politécnica Superior, Universidad de Burgos, Avda. Cantabria, s/n, 09006, Burgos, Spain. Tel: +34 947 258 900; Fax: +34 947258911.

*Corresponding author E-mails: jareglero@ubu.es ; jmiguel@ubu.es
}

\section{S1. Photographs of the aramid films before and after the removal of the IL}
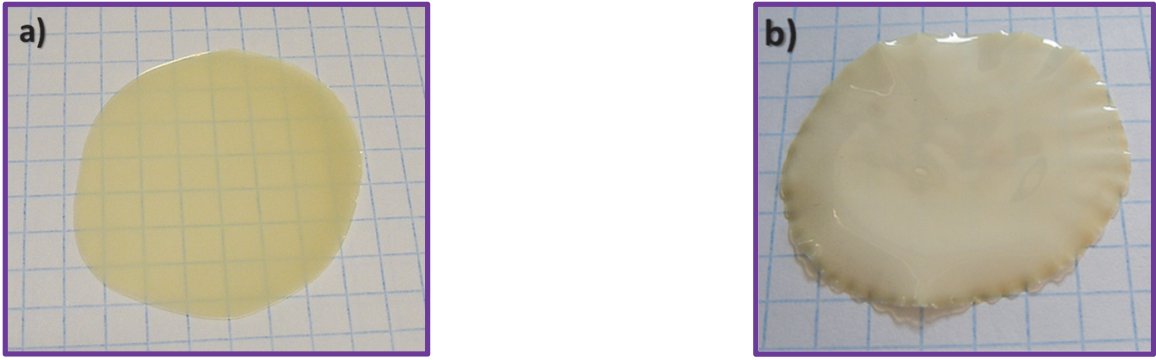

Fig. S1. Photographs of the aramid film with $50 \%$ of IL. a) Before the removal of the IL; b) After removing the IL in distilled water during $24 \mathrm{~h}$.

\section{S2. ${ }^{1} \mathrm{H}-\mathrm{NMR}$ of the 40MPIA/60IL aramid film before the removal of IL}

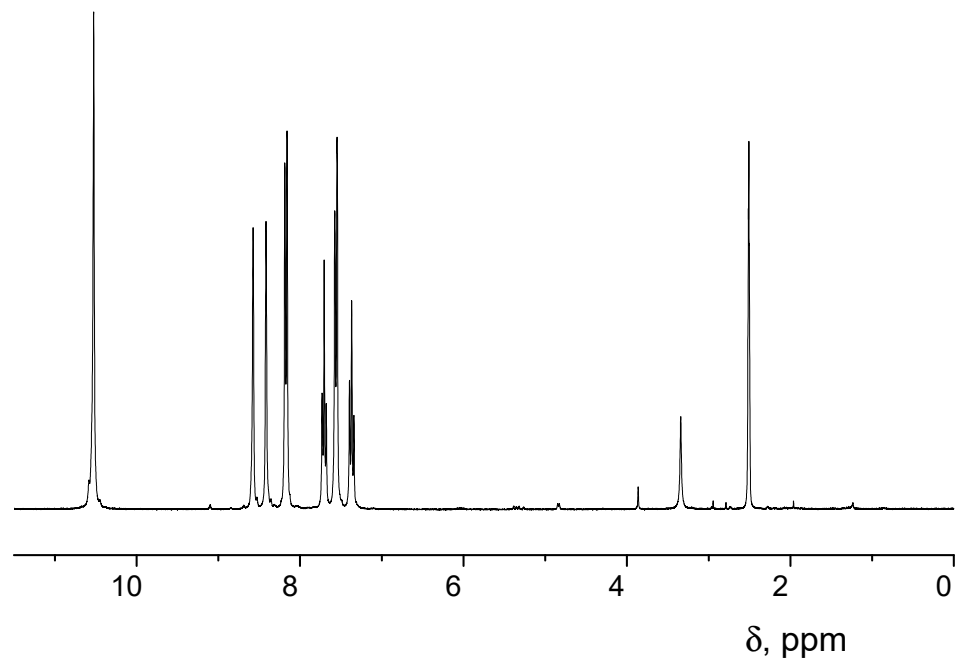

Fig. S2. ${ }^{1} \mathrm{H}-\mathrm{RMN}$ of the $40 \mathrm{MPIA} / 60 \mathrm{IL}$ aramid film after the removal of IL and DMA. 
S3. SEM micrographs of the surface of the porous aramid films
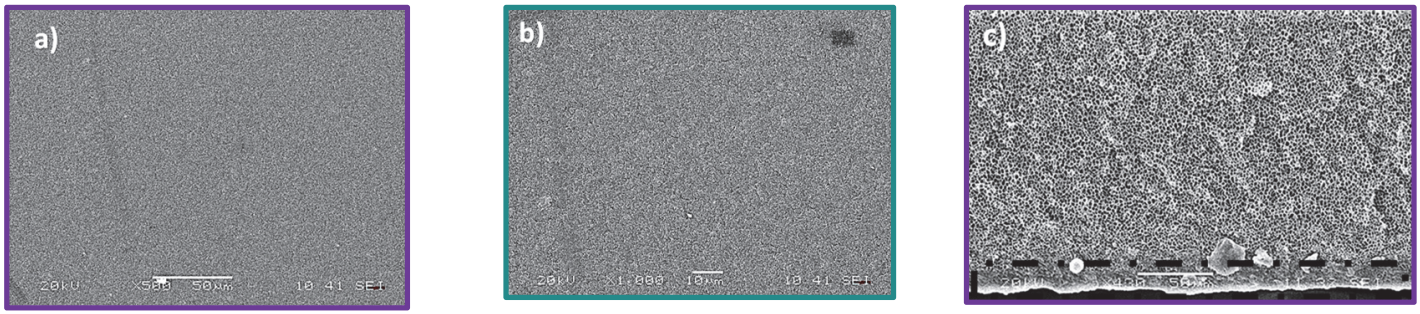

Fig. S3. SEM micrographs of the microporous aramid films; a) surface of 50MPIA/50IL-R film (500x); b) surface of 20MPIA/80IL-R film (1000x); c) detail of the solid outer skin in the cut section (50MPIA/50IL-R film, 500x).

\section{S4. AFM Raman images at different temperatures of 50MPIA/50IL film}
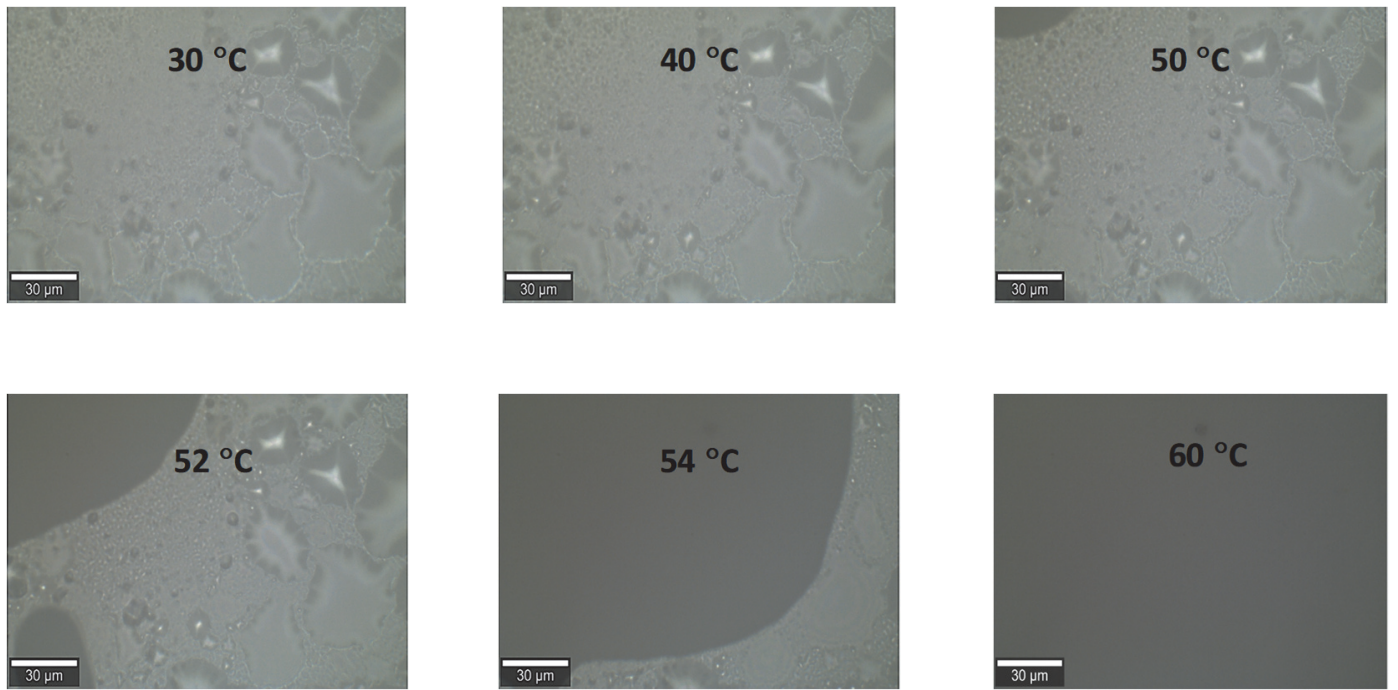

Fig. S4. Optical images taken with the AFM Raman microscope (100x) of the 50MPIA/50IL film at different temperatures, showing the formation of a single MPIA-IL phase around $60^{\circ} \mathrm{C}$.

\section{S5. Ionic liquid distribution and pore morphology in 50MPIA/50IL film}
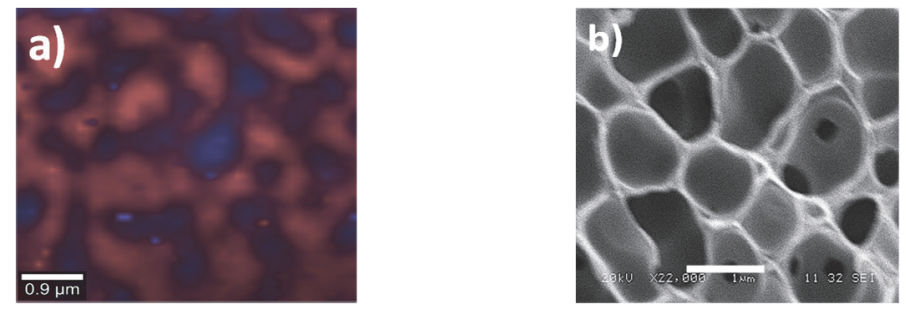

Fig. S5. Distribution of the ionic liquid and pore formation in 50MPIA/50IL film. a) AFM Raman image of the solid film, where the blue regions correspond to the ionic liquid and the red regions correspond to the MPIA (bar scale $0.9 \mu \mathrm{m}$ ); b) SEM micrograph of the porous film after the removal of the ionic liquid (bar scale $1 \mu \mathrm{m}$ ). 


\section{S6. Theoretical calculations of the polyamide-ionic liquid interaction} polymers

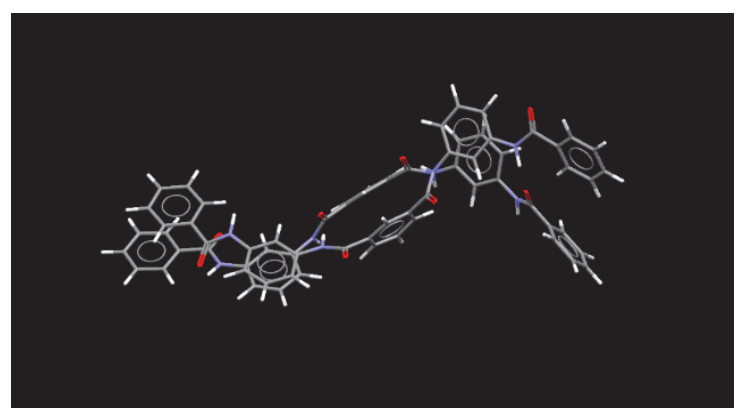

Fig. S6. Optimized structure the model of two interacting polyamides.

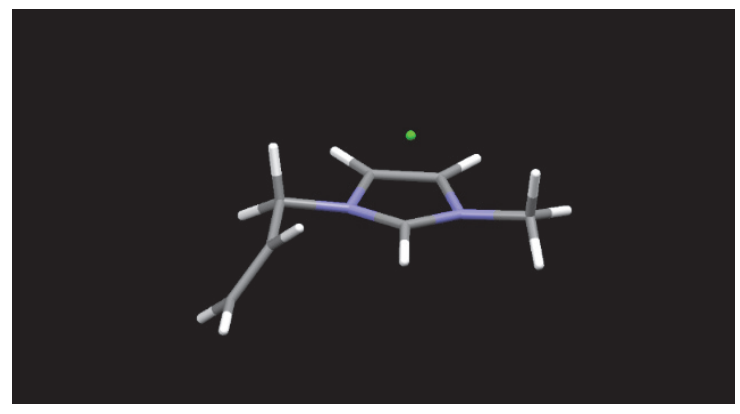

Fig. S7. Optimized structure of an ionic pair of the 1-ethyl-3-methylimidazolium chloride.

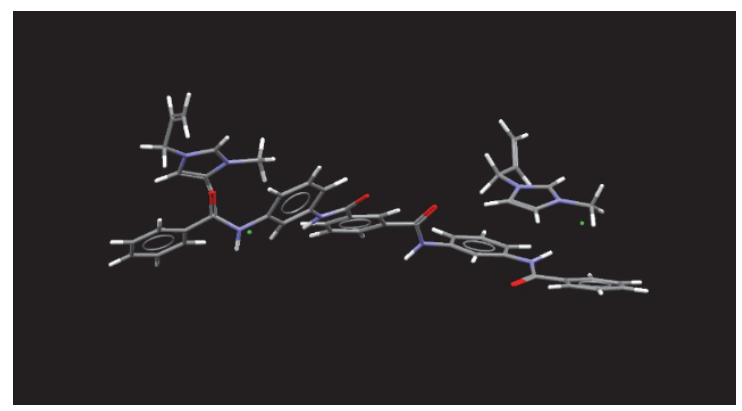

Fig. S8. Optimized structure of the model of one polyamide interacting with two ionic pairs of the 1-ethyl-3-methylimidazolium chloride. 
Table S1. Cartesian coordinates $(\AA)$ of the model of an ionic pair of the 1-ethyl-3methylimidazolium chloride.

\begin{tabular}{|c|c|c|c|c|}
\hline Number & Label & $x$ & $Y$ & z \\
\hline 1 & C & 0.4543 & -0.5333 & 0.1075 \\
\hline 2 & $\mathrm{C}$ & 1.9297 & 0.9506 & -0.584 \\
\hline 3 & C & 0.7183 & 1.5325 & -0.6111 \\
\hline 4 & $\mathrm{~N}$ & -0.2092 & 0.5698 & -0.2656 \\
\hline 5 & $\mathrm{H}$ & -0.0071 & -1.497 & 0.2273 \\
\hline 6 & $\mathrm{H}$ & 2.9017 & 1.3506 & -0.812 \\
\hline 7 & $\mathrm{H}$ & 0.4322 & 2.5374 & -0.8663 \\
\hline 8 & $\mathrm{~N}$ & 1.7439 & -0.3688 & -0.224 \\
\hline 9 & C & 2.7755 & -1.2653 & 0.2374 \\
\hline 10 & $\mathrm{H}$ & 3.7208 & -1.0025 & -0.2303 \\
\hline 11 & $\mathrm{H}$ & 2.8481 & -1.1906 & 1.3232 \\
\hline 12 & $\mathrm{H}$ & 2.5299 & -2.2898 & -0.0344 \\
\hline 13 & C & -1.5758 & 0.8634 & 0.1421 \\
\hline 14 & $\mathrm{H}$ & -1.52 & 1.4701 & 1.0497 \\
\hline 15 & $\mathrm{H}$ & -2.05 & 1.4472 & -0.6483 \\
\hline 16 & $\mathrm{C}$ & -2.3603 & -0.376 & 0.4352 \\
\hline 17 & $\mathrm{H}$ & -2.0692 & -0.8994 & 1.3406 \\
\hline 18 & $\mathrm{C}$ & -3.3608 & -0.8038 & -0.3211 \\
\hline 19 & $\mathrm{H}$ & -3.6646 & -0.2837 & -1.2218 \\
\hline 20 & $\mathrm{H}$ & -3.9234 & -1.6898 & -0.0605 \\
\hline 21 & $\mathrm{Cl}$ & 0.4523 & -0.4005 & 2.5209 \\
\hline
\end{tabular}

Table S2. Cartesian coordinates ( $\AA$ ) of the model of two interacting polyamides.

\begin{tabular}{|c|c|c|c|c|}
\hline Number & Label & $X$ & $Y$ & $Z$ \\
\hline 1 & $\mathrm{C}$ & -3.6067 & -8.1823 & -5.9709 \\
\hline 2 & $\mathrm{C}$ & -2.3976 & -8.7512 & -5.5957 \\
\hline 3 & $\mathrm{C}$ & -1.4741 & -9.1034 & -6.5802 \\
\hline 4 & $\mathrm{C}$ & -1.7821 & -8.8527 & -7.9197 \\
\hline 5 & $\mathrm{C}$ & -2.9915 & -8.2886 & -8.2714 \\
\hline 6 & $\mathrm{C}$ & -3.9233 & -7.9602 & -7.3002 \\
\hline 7 & $\mathrm{H}$ & -2.1826 & -8.9099 & -4.5516 \\
\hline 8 & $\mathrm{H}$ & -1.0573 & -9.0812 & -8.6911 \\
\hline 9 & $\mathrm{H}$ & -3.2023 & -8.0875 & -9.3125 \\
\hline
\end{tabular}


Material suplementario. Capitulo 3

Sensory polymeric foams as a tool for improving sensing performance of sensory polymers

\begin{tabular}{|c|c|c|c|c|}
\hline 10 & $\mathrm{H}$ & -4.8748 & -7.5261 & -7.575 \\
\hline 11 & $\mathrm{~N}$ & -0.2289 & -9.6759 & -6.3199 \\
\hline 12 & C & 0.2742 & -10.1238 & -5.1353 \\
\hline 13 & $\mathrm{H}$ & 0.3897 & -9.674 & -7.1139 \\
\hline 14 & $\mathrm{O}$ & -0.3436 & -10.0786 & -4.0913 \\
\hline 15 & $\mathrm{C}$ & 1.6596 & -10.6919 & -5.188 \\
\hline 16 & C & 2.2431 & -11.0303 & -3.9698 \\
\hline 17 & C & 2.384 & -10.9097 & -6.3583 \\
\hline 18 & C & 3.5169 & -11.5687 & -3.9199 \\
\hline 19 & $\mathrm{H}$ & 1.6862 & -10.8642 & -3.0585 \\
\hline 20 & C & 3.6579 & -11.4522 & -6.3093 \\
\hline 21 & $\mathrm{H}$ & 1.9893 & -10.661 & -7.3347 \\
\hline 22 & C & 4.2288 & -11.7838 & -5.0905 \\
\hline 23 & $\mathrm{H}$ & 3.954 & -11.823 & -2.9634 \\
\hline 24 & $\mathrm{H}$ & 4.2028 & -11.6147 & -7.2297 \\
\hline 25 & $\mathrm{H}$ & 5.223 & -12.2102 & -5.0543 \\
\hline 26 & $\mathrm{~N}$ & -4.541 & -7.8345 & -4.9552 \\
\hline 27 & $\mathrm{C}$ & -4.7798 & -6.5561 & -4.5898 \\
\hline 28 & $\mathrm{H}$ & -5.0866 & -8.5757 & -4.5502 \\
\hline 29 & 0 & -4.2154 & -5.6041 & -5.0977 \\
\hline 30 & C & -5.8303 & -6.3516 & -3.5432 \\
\hline 31 & C & -6.2162 & -7.3307 & -2.6301 \\
\hline 32 & $\mathrm{C}$ & -6.4514 & -5.1095 & -3.5102 \\
\hline 33 & C & -7.2362 & -7.0825 & -1.7265 \\
\hline 34 & $\mathrm{H}$ & -5.7085 & -8.2867 & -2.5867 \\
\hline 35 & $\mathrm{C}$ & -7.5122 & -4.8775 & -2.645 \\
\hline 36 & $\mathrm{H}$ & -6.1297 & -4.3309 & -4.1884 \\
\hline 37 & C & -7.9023 & -5.8672 & -1.7482 \\
\hline 38 & $\mathrm{H}$ & -7.5115 & -7.8379 & -1.0033 \\
\hline 39 & $\mathrm{H}$ & -8.6996 & -5.684 & -1.0379 \\
\hline 40 & C & -8.2006 & -3.5555 & -2.7274 \\
\hline 41 & $\mathrm{O}$ & -7.591 & -2.525 & -2.9191 \\
\hline 42 & $\mathrm{~N}$ & -9.5576 & -3.6265 & -2.61 \\
\hline 43 & $\mathrm{H}$ & -9.9725 & -4.5422 & -2.661 \\
\hline 44 & C & -10.4285 & -2.5255 & -2.7521 \\
\hline 45 & C & -11.4913 & -2.6255 & -3.6431 \\
\hline 46 & C & -10.238 & -1.358 & -2.0278 \\
\hline 47 & $\mathrm{C}$ & -12.3731 & -1.564 & -3.8073 \\
\hline
\end{tabular}


Material suplementario. Capitulo 3

Sensory polymeric foams as a tool for improving sensing performance of sensory polymers

\begin{tabular}{|c|c|c|c|c|}
\hline 48 & $\mathrm{H}$ & -11.6121 & -3.5253 & -4.238 \\
\hline 49 & C & -11.1193 & -0.3038 & -2.204 \\
\hline 50 & $\mathrm{H}$ & -9.4167 & -1.2709 & -1.332 \\
\hline 51 & C & -12.1872 & -0.3948 & -3.078 \\
\hline 52 & $\mathrm{H}$ & -10.9639 & 0.6155 & -1.6572 \\
\hline 53 & $\mathrm{H}$ & -12.8604 & 0.4408 & -3.1901 \\
\hline 54 & $\mathrm{~N}$ & -13.4455 & -1.7112 & -4.7049 \\
\hline 55 & C & -13.839 & -0.765 & -5.6066 \\
\hline 56 & $\mathrm{H}$ & -13.7912 & -2.6462 & -4.8423 \\
\hline 57 & $\mathrm{O}$ & -13.2815 & 0.3062 & -5.7198 \\
\hline 58 & C & -15.0048 & -1.1376 & -6.4572 \\
\hline 59 & C & -16.0094 & -1.9957 & -6.0177 \\
\hline 60 & C & -15.1027 & -0.5585 & -7.7198 \\
\hline 61 & $\mathrm{C}$ & -17.0882 & -2.2866 & -6.8383 \\
\hline 62 & $\mathrm{H}$ & -15.9825 & -2.4111 & -5.0175 \\
\hline 63 & $\mathrm{C}$ & -16.1743 & -0.8608 & -8.5423 \\
\hline 64 & $\mathrm{H}$ & -14.3315 & 0.1216 & -8.0559 \\
\hline 65 & $\mathrm{C}$ & -17.1676 & -1.7259 & -8.104 \\
\hline 66 & $\mathrm{H}$ & -17.8723 & -2.9425 & -6.4845 \\
\hline 67 & $\mathrm{H}$ & -16.2362 & -0.4194 & -9.5279 \\
\hline 68 & $\mathrm{H}$ & -18.0062 & -1.9575 & -8.7472 \\
\hline 69 & C & -2.792 & -4.9013 & -8.5273 \\
\hline 70 & $\mathrm{C}$ & -1.786 & -5.2916 & -7.6498 \\
\hline 71 & C & -0.5559 & -5.7251 & -8.1221 \\
\hline 72 & C & -0.3098 & -5.7724 & -9.4888 \\
\hline 73 & $\mathrm{C}$ & -1.3171 & -5.374 & -10.3538 \\
\hline 74 & C & -2.5508 & -4.9373 & -9.8995 \\
\hline 75 & $\mathrm{H}$ & -1.9841 & -5.2977 & -6.5841 \\
\hline 76 & $\mathrm{H}$ & 0.6427 & -6.1016 & -9.8723 \\
\hline 77 & $\mathrm{H}$ & -1.1322 & -5.399 & -11.4198 \\
\hline 78 & $\mathrm{H}$ & -3.3076 & -4.6308 & -10.6043 \\
\hline 79 & $\mathrm{~N}$ & 0.4101 & -6.0747 & -7.1599 \\
\hline 80 & C & 1.3069 & -7.0874 & -7.2244 \\
\hline 81 & $\mathrm{H}$ & 0.3634 & -5.5635 & -6.2944 \\
\hline 82 & $\mathrm{O}$ & 1.4871 & -7.7766 & -8.2138 \\
\hline 83 & C & 2.0783 & -7.3217 & -5.9666 \\
\hline 84 & C & 3.378 & -7.807 & -6.0749 \\
\hline 85 & C & 1.5147 & -7.159 & -4.7034 \\
\hline
\end{tabular}


Material suplementario. Capitulo 3

Sensory polymeric foams as a tool for improving sensing performance of sensory

\begin{tabular}{|c|c|c|c|c|}
\hline 86 & C & 4.1126 & -8.0969 & -4.9386 \\
\hline 87 & $\mathrm{H}$ & 3.8073 & -7.9653 & -7.0551 \\
\hline 88 & C & 2.2463 & -7.4646 & -3.5671 \\
\hline 89 & $\mathrm{H}$ & 0.4824 & -6.8481 & -4.59 \\
\hline 90 & C & 3.5484 & -7.9254 & -3.6831 \\
\hline 91 & $\mathrm{H}$ & 5.1226 & -8.4715 & -5.0329 \\
\hline 92 & $\mathrm{H}$ & 1.7897 & -7.3593 & -2.5924 \\
\hline 93 & $\mathrm{H}$ & 4.1179 & -8.1669 & -2.7955 \\
\hline 94 & $\mathrm{~N}$ & -4.0305 & -4.5615 & -7.9749 \\
\hline 95 & C & -4.9373 & -3.6808 & -8.4909 \\
\hline 96 & $\mathrm{H}$ & -4.1702 & -4.8612 & -7.0171 \\
\hline 97 & $\mathrm{O}$ & -4.7841 & -3.0524 & -9.5128 \\
\hline 98 & C & -6.1724 & -3.5402 & -7.6563 \\
\hline 99 & C & -6.8205 & -4.6496 & -7.1226 \\
\hline 100 & C & -6.7036 & -2.2722 & -7.4553 \\
\hline 101 & C & -7.9784 & -4.4888 & -6.3784 \\
\hline 102 & $\mathrm{H}$ & -6.4407 & -5.6454 & -7.3141 \\
\hline 103 & C & -7.8174 & -2.103 & -6.6445 \\
\hline 104 & $\mathrm{H}$ & -6.23 & -1.4115 & -7.9097 \\
\hline 105 & C & -8.4602 & -3.2167 & -6.1147 \\
\hline 106 & $\mathrm{H}$ & -8.498 & -5.3583 & -5.9968 \\
\hline 107 & $\mathrm{H}$ & -9.3545 & -3.0847 & -5.5182 \\
\hline 108 & $\mathrm{C}$ & -8.343 & -0.7207 & -6.4001 \\
\hline 109 & $\mathrm{O}$ & -8.5385 & 0.0545 & -7.3071 \\
\hline 110 & $\mathrm{~N}$ & -8.558 & -0.4518 & -5.0824 \\
\hline 111 & $\mathrm{H}$ & -8.1829 & -1.0984 & -4.4004 \\
\hline 112 & C & -9.0412 & 0.7637 & -4.5723 \\
\hline 113 & C & -10.138 & 1.3926 & -5.1367 \\
\hline 114 & C & -8.4365 & 1.3051 & -3.4425 \\
\hline 115 & C & -10.6559 & 2.5578 & -4.5733 \\
\hline 116 & $\mathrm{H}$ & -10.6165 & 0.9566 & -6.0016 \\
\hline 117 & C & -8.9521 & 2.4648 & -2.8919 \\
\hline 118 & $\mathrm{H}$ & -7.573 & 0.8195 & -3.0061 \\
\hline 119 & C & -10.0554 & 3.103 & -3.438 \\
\hline 120 & $\mathrm{H}$ & -8.4801 & 2.8933 & -2.0171 \\
\hline 121 & $\mathrm{H}$ & -10.4285 & 4.0109 & -2.9945 \\
\hline 122 & $\mathrm{~N}$ & -11.7964 & 3.0914 & -5.1826 \\
\hline 123 & C & -12.3524 & 4.3229 & -5.0111 \\
\hline
\end{tabular}


Material suplementario. Capitulo 3

Sensory polymeric foams as a tool for improving sensing performance of sensory polymers

\begin{tabular}{|l|l|l|l|l|}
\hline 124 & H & -12.2176 & 2.4932 & -5.8751 \\
\hline 125 & O & -11.8998 & 5.1801 & -4.2824 \\
\hline 126 & C & -13.5868 & 4.5751 & -5.823 \\
\hline 127 & C & -14.4584 & 3.5676 & -6.2291 \\
\hline 128 & C & -13.8818 & 5.8975 & -6.1446 \\
\hline 129 & C & -15.5955 & 3.8783 & -6.9602 \\
\hline 130 & H & -14.2847 & 2.5338 & -5.9592 \\
\hline 131 & C & -15.0106 & 6.2037 & -6.8851 \\
\hline 132 & H & -13.2174 & 6.6831 & -5.811 \\
\hline 133 & C & -15.8705 & 5.1946 & -7.2962 \\
\hline 134 & H & -16.2697 & 3.0862 & -7.2596 \\
\hline 135 & H & -15.2235 & 7.2338 & -7.1388 \\
\hline 136 & H & -16.7562 & 5.4356 & -7.8695 \\
\hline
\end{tabular}

Table S3. Cartesian coordinates $(\AA)$ of the model of one polyamide interacting with two ionic pairs of the 1-ethyl-3-methylimidazolium chloride.

\begin{tabular}{|c|c|c|c|c|}
\hline Number & Label & $\mathbf{X}$ & $\mathbf{Y}$ & $\mathbf{Z}$ \\
\hline 1 & $\mathrm{C}$ & -2.094 & -3.4825 & -8.3444 \\
\hline 2 & $\mathrm{C}$ & -1.5745 & -4.2982 & -7.3481 \\
\hline 3 & $\mathrm{C}$ & -0.2985 & -4.8428 & -7.4982 \\
\hline 4 & $\mathrm{C}$ & 0.4113 & -4.5927 & -8.6783 \\
\hline 5 & $\mathrm{C}$ & -0.1375 & -3.8056 & -9.6727 \\
\hline 6 & $\mathrm{C}$ & -1.3906 & -3.2318 & -9.5129 \\
\hline 7 & $\mathrm{H}$ & -2.157 & -4.4892 & -6.4623 \\
\hline 8 & $\mathrm{H}$ & 1.409 & -4.9978 & -8.7902 \\
\hline 9 & $\mathrm{H}$ & 0.4292 & -3.622 & -10.5758 \\
\hline 10 & $\mathrm{H}$ & -1.8102 & -2.5862 & -10.2734 \\
\hline 11 & $\mathrm{~N}$ & 0.3527 & -5.5926 & -6.5197 \\
\hline 12 & $\mathrm{C}$ & -0.2133 & -6.1892 & -5.4395 \\
\hline 13 & $\mathrm{H}$ & 1.3794 & -5.5809 & -6.6144 \\
\hline 14 & $\mathrm{O}$ & -1.3986 & -6.135 & -5.1694 \\
\hline 15 & $\mathrm{C}$ & 0.7322 & -6.9235 & -4.5366 \\
\hline 16 & $\mathrm{C}$ & 1.9944 & -7.3653 & -4.9254 \\
\hline 17 & $\mathrm{C}$ & 0.2955 & -7.1746 & -3.2356 \\
\hline 18 & $\mathrm{C}$ & 2.811 & -8.025 & -4.0176 \\
\hline 19 & $\mathrm{H}$ & 2.375 & -7.1844 & -5.9215 \\
\hline 20 & $\mathrm{C}$ & 1.1175 & -7.8229 & -2.3293 \\
\hline 21 & $\mathrm{H}$ & -0.6983 & -6.8608 & -2.9452 \\
\hline
\end{tabular}


Material suplementario. Capitulo 3

Sensory polymeric foams as a tool for improving sensing performance of sensory

\begin{tabular}{|c|c|c|c|c|}
\hline 22 & C & 2.3812 & -8.2492 & -2.7194 \\
\hline 23 & $\mathrm{H}$ & 3.7907 & -8.3585 & -4.3327 \\
\hline 24 & $\mathrm{H}$ & 0.7702 & -8.0058 & -1.3206 \\
\hline 25 & $\mathrm{H}$ & 3.0233 & -8.7616 & -2.0144 \\
\hline 26 & $\mathrm{~N}$ & -3.3635 & -2.8788 & -8.1551 \\
\hline 27 & $\mathrm{C}$ & -3.6071 & -1.9554 & -7.1916 \\
\hline 28 & $\mathrm{H}$ & -4.1272 & -3.1929 & -8.7296 \\
\hline 29 & $\mathrm{O}$ & -2.7731 & -1.6043 & -6.3784 \\
\hline 30 & C & -4.9885 & -1.3867 & -7.1876 \\
\hline 31 & $\mathrm{C}$ & -5.7427 & -1.2377 & -8.3491 \\
\hline 32 & C & -5.5137 & -0.9548 & -5.9776 \\
\hline 33 & $\mathrm{C}$ & -7.0093 & -0.6833 & -8.2887 \\
\hline 34 & $\mathrm{H}$ & -5.3357 & -1.5145 & -9.3143 \\
\hline 35 & $\mathrm{C}$ & -6.7986 & -0.4281 & -5.9054 \\
\hline 36 & $\mathrm{H}$ & -4.9212 & -1.0364 & -5.0765 \\
\hline 37 & $\mathrm{C}$ & -7.5468 & -0.2872 & -7.0738 \\
\hline 38 & $\mathrm{H}$ & -7.5871 & -0.5495 & -9.193 \\
\hline 39 & $\mathrm{H}$ & -8.5434 & 0.1459 & -7.0787 \\
\hline 40 & C & -7.2809 & -0.0098 & -4.5477 \\
\hline 41 & $\mathrm{O}$ & -6.5042 & 0.1519 & -3.6293 \\
\hline 42 & $\mathrm{~N}$ & -8.6259 & 0.1519 & -4.4324 \\
\hline 43 & $\mathrm{H}$ & -9.2093 & -0.0015 & -5.2505 \\
\hline 44 & $\mathrm{C}$ & -9.3419 & 0.6332 & -3.3375 \\
\hline 45 & C & -10.7234 & 0.6006 & -3.4846 \\
\hline 46 & $\mathrm{C}$ & -8.8012 & 1.2202 & -2.1905 \\
\hline 47 & C & -11.5637 & 1.1987 & -2.5638 \\
\hline 48 & $\mathrm{H}$ & -11.141 & 0.2017 & -4.4027 \\
\hline 49 & $\mathrm{C}$ & -9.6641 & 1.7923 & -1.2646 \\
\hline 50 & $\mathrm{H}$ & -7.7369 & 1.2427 & -2.0235 \\
\hline 51 & $\mathrm{C}$ & -11.0434 & 1.8111 & -1.4302 \\
\hline 52 & $\mathrm{H}$ & -9.24 & 2.2449 & -0.3776 \\
\hline 53 & $\mathrm{H}$ & -11.6841 & 2.2736 & -0.6953 \\
\hline 54 & $\mathrm{~N}$ & -12.932 & 1.164 & -2.9001 \\
\hline 55 & $\mathrm{C}$ & -13.7888 & 2.2103 & -2.8705 \\
\hline 56 & $\mathrm{H}$ & -13.1703 & 0.4198 & -3.5367 \\
\hline 57 & 0 & -13.6551 & 3.1812 & -2.1444 \\
\hline 58 & C & -14.9157 & 2.1051 & -3.8466 \\
\hline 59 & $\mathrm{C}$ & -14.713 & 1.5885 & -5.1266 \\
\hline
\end{tabular}


Material suplementario. Capitulo 3

Sensory polymeric foams as a tool for improving sensing performance of sensory

\begin{tabular}{|c|c|c|c|c|}
\hline 60 & C & -16.1632 & 2.6162 & -3.499 \\
\hline 61 & C & -15.7588 & 1.5739 & -6.038 \\
\hline 62 & $\mathrm{H}$ & -13.7349 & 1.2404 & -5.451 \\
\hline 63 & $\mathrm{C}$ & -17.2064 & 2.5895 & -4.409 \\
\hline 64 & $\mathrm{H}$ & -16.3161 & 3.0191 & -2.505 \\
\hline 65 & C & -17.0047 & 2.0677 & -5.681 \\
\hline 66 & $\mathrm{H}$ & -15.5911 & 1.1779 & -7.031 \\
\hline 67 & $\mathrm{H}$ & -18.1792 & 2.9688 & -4.126 \\
\hline 68 & $\mathrm{H}$ & -17.8197 & 2.0463 & -6.392 \\
\hline 69 & $\mathrm{Cl}$ & -11.0822 & 0.7842 & -6.792 \\
\hline 70 & $\mathrm{Cl}$ & 3.4371 & -4.9843 & -6.962 \\
\hline 71 & $\mathrm{C}$ & 2.0746 & -2.8734 & -5.247 \\
\hline 72 & $\mathrm{C}$ & 0.5132 & -3.4916 & -3.838 \\
\hline 73 & $\mathrm{C}$ & -0.0644 & -2.7051 & -4.775 \\
\hline 74 & $\mathrm{~N}$ & 0.9344 & -2.325 & -5.638 \\
\hline 75 & $\mathrm{H}$ & 3.0201 & -2.8181 & -5.759 \\
\hline 76 & $\mathrm{H}$ & 0.0832 & -4.0093 & -2.999 \\
\hline 77 & $\mathrm{H}$ & -1.0882 & -2.4065 & -4.926 \\
\hline 78 & $\mathrm{~N}$ & 1.8473 & -3.5812 & -4.150 \\
\hline 79 & $\mathrm{C}$ & 2.8581 & -4.3776 & -3.478 \\
\hline 80 & $\mathrm{H}$ & 3.4492 & -3.7549 & -2.809 \\
\hline 81 & $\mathrm{H}$ & 2.3741 & -5.1661 & -2.908 \\
\hline 82 & $\mathrm{H}$ & 3.4906 & -4.8299 & -4.241 \\
\hline 83 & $\mathrm{C}$ & 0.7478 & -1.5019 & -6.834 \\
\hline 84 & $\mathrm{H}$ & -0.1176 & -1.9042 & -7.361 \\
\hline 85 & $\mathrm{H}$ & 0.4974 & -0.4882 & -6.519 \\
\hline 86 & $\mathrm{C}$ & 1.9594 & -1.5215 & -7.707 \\
\hline 87 & $\mathrm{H}$ & 2.3232 & -2.499 & -8.012 \\
\hline 88 & $\mathrm{C}$ & 2.5729 & -0.4188 & -8.112 \\
\hline 89 & $\mathrm{H}$ & 2.2419 & 0.5689 & -7.815 \\
\hline 90 & $\mathrm{H}$ & 3.4276 & -0.4658 & -8.772 \\
\hline 91 & C & -11.9475 & 4.7723 & -4.175 \\
\hline 92 & $\mathrm{C}$ & -12.1519 & 3.8231 & -6.143 \\
\hline 93 & C & -13.299 & 4.4919 & -5.874 \\
\hline 94 & $\mathrm{~N}$ & -13.148 & 5.0827 & -4.645 \\
\hline 95 & $\mathrm{H}$ & -11.556 & 5.0621 & -3.215 \\
\hline 96 & $\mathrm{H}$ & -11.872 & 3.1545 & -6.945 \\
\hline 97 & $\mathrm{H}$ & -14.2125 & 4.5644 & -6.437 \\
\hline
\end{tabular}


Material suplementario. Capitulo 3 Sensory polymeric foams as a tool for improving sensing performance of sensory polymers

\begin{tabular}{|c|c|c|c|c|}
\hline 98 & $\mathrm{~N}$ & -11.3233 & 4.0241 & -5.0706 \\
\hline 99 & $\mathrm{C}$ & -9.9546 & 3.5388 & -4.9699 \\
\hline 100 & $\mathrm{H}$ & -9.8917 & 2.6165 & -5.5473 \\
\hline 101 & $\mathrm{H}$ & -9.2723 & 4.2842 & -5.374 \\
\hline 102 & $\mathrm{H}$ & -9.7148 & 3.3391 & -3.9294 \\
\hline 103 & $\mathrm{C}$ & -14.1838 & 5.8069 & -3.9094 \\
\hline 104 & $\mathrm{H}$ & -14.846 & 6.249 & -4.6544 \\
\hline 105 & $\mathrm{H}$ & -14.7509 & 5.0837 & -3.3274 \\
\hline 106 & $\mathrm{C}$ & -13.599 & 6.8621 & -3.0271 \\
\hline 107 & $\mathrm{H}$ & -13.179 & 7.7344 & -3.5169 \\
\hline 108 & $\mathrm{C}$ & -13.5906 & 6.7646 & -1.7049 \\
\hline 109 & $\mathrm{H}$ & -13.9899 & 5.8952 & -1.1979 \\
\hline 110 & $\mathrm{H}$ & -13.1792 & 7.5502 & -1.0861 \\
\hline
\end{tabular}

\section{S7. TGA curves}

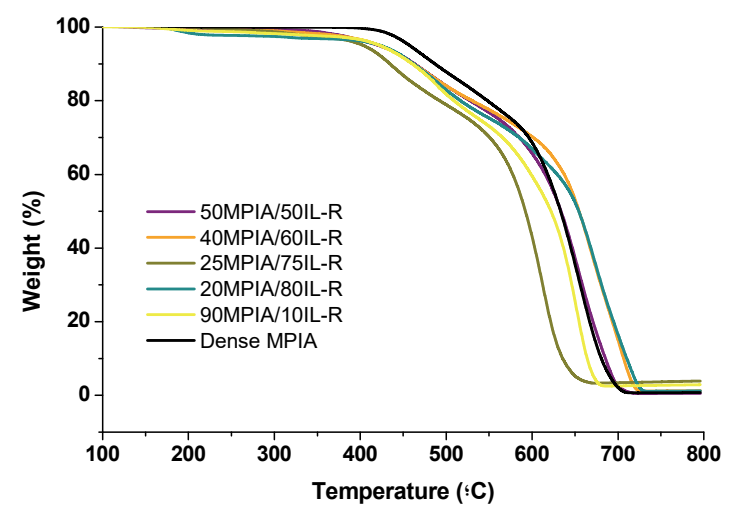

Fig. S9. Thermogravimetric curves of the aramid films.

\section{S8. DSC curves}

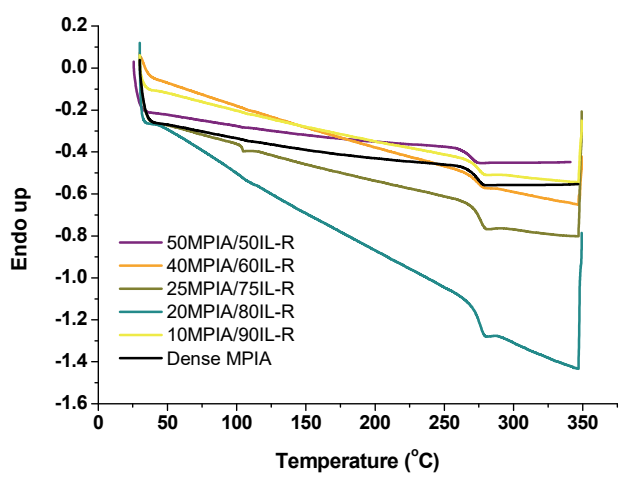

Fig. S10. DSC analysis of the aramid films. 


\section{S9. Tensile tests}

polymers

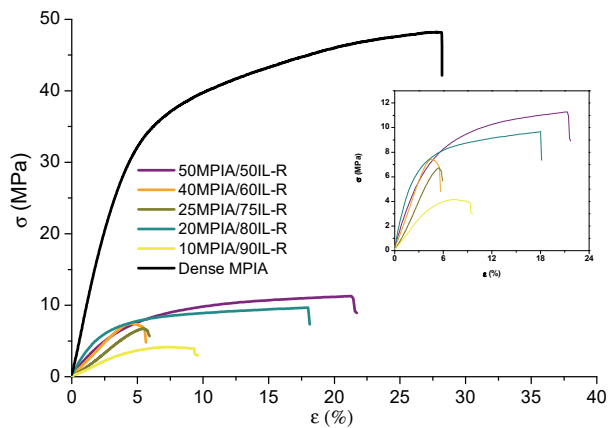

Fig. S11. Tensile tests of aramid films; Inset: detail of the curves of the microporous aramid films. 


\section{Sensory polymeric foams as a tool for improving sensing performance of sensory polymers}

Blanca S. Pascual, ${ }^{a}$ Saúl Vallejos, ${ }^{a}$ Cipriano Ramos, ${ }^{b}$ María Teresa Sanz,${ }^{b}$ José A. Reglero Ruiz, ${ }^{*, a}$ Félix C. García ${ }^{a}$ and José M. García ${ }^{a}$

a Departamento de Química, Facultad de Ciencias, Universidad de Burgos, Plaza de Misael Bañuelos s/n, 09001 Burgos, Spain. Tel: +34 947258 085; Fax: +34 947258831 .

b Departamento de Biotecnología y Ciencia de los Alimentos, Área de Ingeniería Química, Facultad de Ciencias, Universidad de Burgos, Plaza de Misael Bañuelos s/n, 09001 Burgos, Spain. Tel: +34 947258 085; Fax: +34 947258831.

* Corresponding author email: jareglero@ubu.es

\section{S1. Colorimetric detection of $\mathrm{Hg}(\mathrm{II})$}

\section{S1.1. Green (G) and Blue (B) parameters variation of images of sensory discs and the reference material}

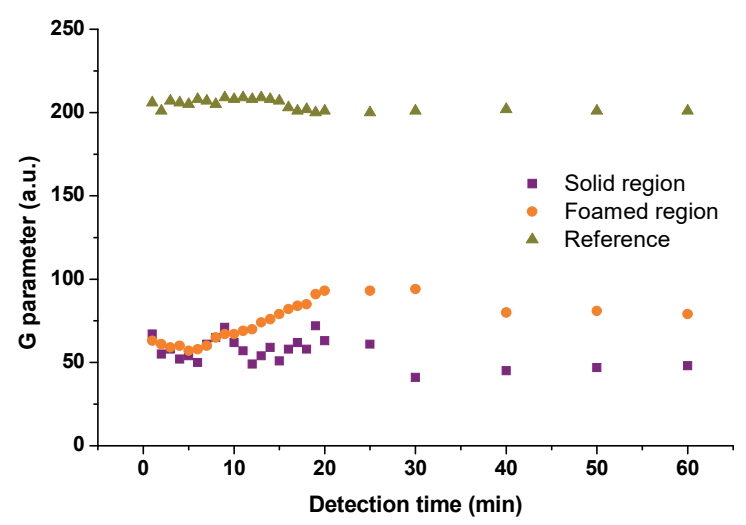

Fig. S1. Evolution of the green parameter $(G)$ of images of sensory films along time upon entering into contact with a water solution of $\mathrm{Hg}(\mathrm{II})(913 \mathrm{ppm})$.

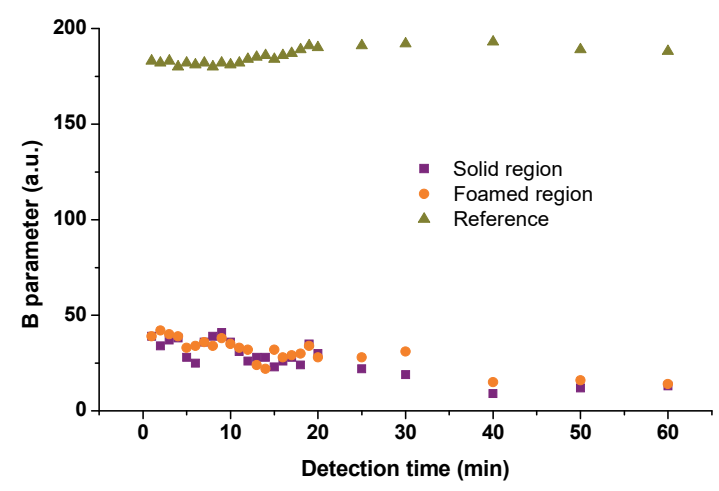

Fig. S2. Evolution of the blue parameter (B) of images of sensory films along time upon entering into contact with a water solution of $\mathrm{Hg}(\mathrm{II})$ (913 ppm). 
S1.2. Titration of $\mathrm{Hg}$ (II) examining the analysis of the RGB parameters of both foamed and solid discs using a digital picture

\section{S1.2.1 Foamed discs}

Table S1. Hg(II) concentrations, RGB parameters and PC1 of each foamed disk. Values in red were neglected for plotting the titration curves.

\begin{tabular}{|ccccc|}
\hline $\mathbf{H g}(\mathbf{I I})](\mathbf{M})$ & $\mathbf{R}$ & $\mathbf{G}$ & $\mathbf{B}$ & PC1 (R\&G) \\
0 & 215 & 215 & 191 & Not used \\
$1 \times 10^{-7}$ & 16 & 28 & 32 & -0.5770 \\
$5 \times 10^{-7}$ & 14 & 31 & 32 & -0.5666 \\
$1 \times 10^{-6}$ & 18 & 28 & 35 & -0.5596 \\
$2 \times 10^{-6}$ & 13 & 22 & 27 & Not used \\
$3 \times 10^{-6}$ & 18 & 32 & 33 & -0.5226 \\
\hline
\end{tabular}

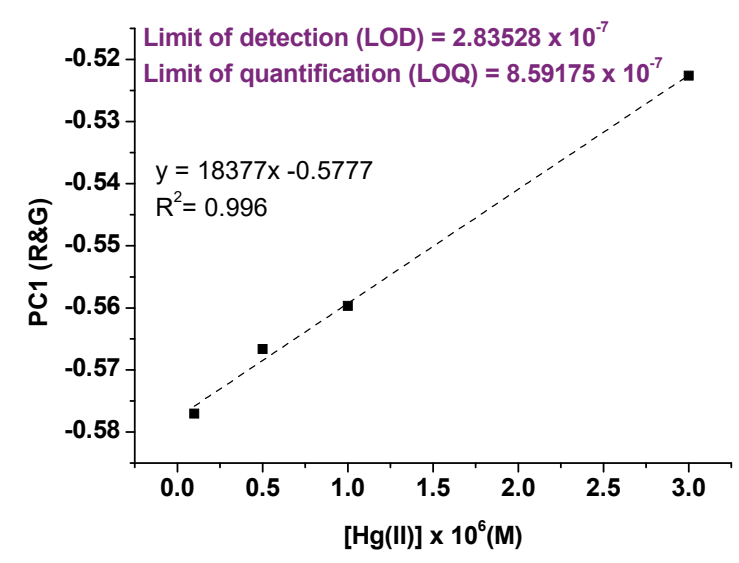

Fig. S3. Variation of the PC1 vs the $\mathrm{Hg}(\mathrm{II})$ concentration. Upon fitting with a two-degree polynomial, the mercury concentration in the test sample was calculated.

\section{S1.2.2 Solid discs}

Table S2. Hg(II) concentrations, RGB parameters and PC1 of each solid disk. Values in red were neglected for plotting the titration curves.

$\begin{array}{ccccc}{[\mathbf{H g}(\mathbf{I I})](\boldsymbol{M})} & \boldsymbol{R} & \boldsymbol{G} & \boldsymbol{B} & \boldsymbol{P C 1}(\boldsymbol{R} \& \mathbf{G}) \\ 0 & 39 & 113 & 98 & \text { Not used } \\ 1 \times 10^{-7} & 20 & 100 & 73 & -0.7688 \\ 5 \times 10^{-7} & 28 & 95 & 80 & -0.2183 \\ 1 \times 10^{-6} & 28 & 97 & 80 & -03501 \\ 2 \times 10^{-6} & 22 & 83 & 66 & \text { Not used } \\ 3 \times 10^{-6} & 88 & 86 & 91 & 2.0352\end{array}$




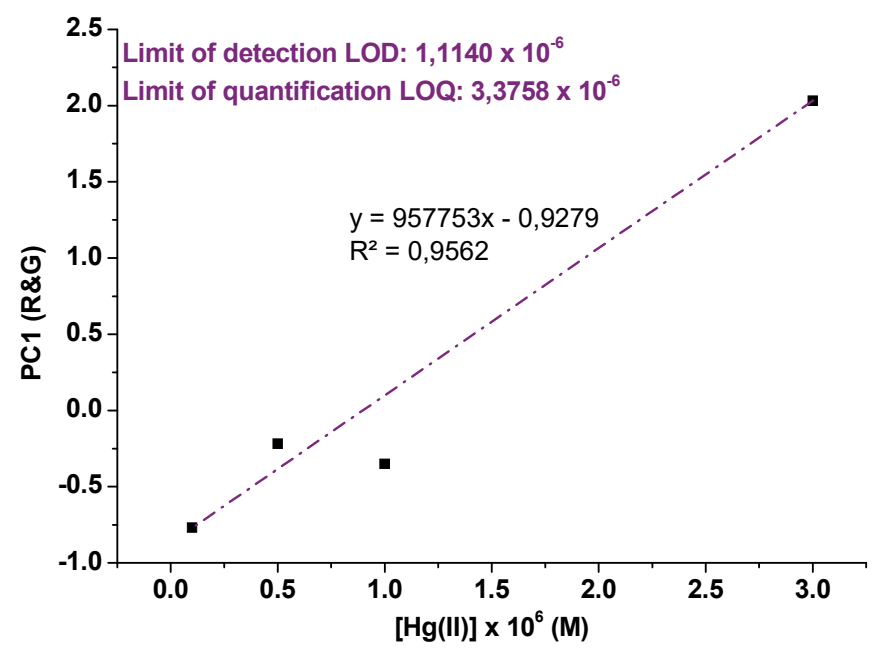

Fig. S4. Variation of the PC1 vs the logarithm of the $\mathrm{Hg}(\mathrm{II})$ concentration. Upon fitting with a two-degree polynomial, the mercury concentration in the test sample was calculated. 